\title{
Site U1423'
}

R. Tada, R.W. Murray, C.A. Alvarez Zarikian, W.T. Anderson Jr., M.-A. Bassetti, B.J. Brace, S.C. Clemens, M.H. da Costa Gurgel, G.R. Dickens, A.G. Dunlea, S.J. Gallagher, L. Giosan, A.C.G. Henderson, A.E. Holbourn, K. Ikehara, T. Irino, T. Itaki, A. Karasuda, C.W. Kinsley, Y. Kubota, G.S. Lee, K.E. Lee, J. Lofi, C.I.C.D. Lopes, L.C. Peterson, M. Saavedra-Pellitero, T. Sagawa, R.K. Singh, S. Sugisaki, S. Toucanne, S. Wan, C. Xuan, H. Zheng, and M. Ziegler²

\section{Chapter contents}

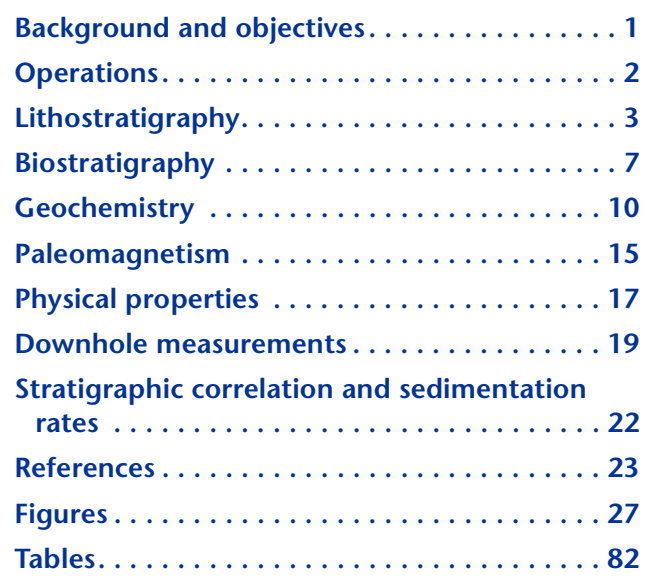

${ }^{1}$ Tada, R., Murray, R.W., Alvarez Zarikian, C.A., Anderson, W.T., Jr., Bassetti, M.-A., Brace, B.J., Clemens, S.C., da Costa Gurgel, M.H., Dickens, G.R., Dunlea, A.G., Gallagher, S.J., Giosan, L., Henderson, A.C.G., Holbourn, A.E., Ikehara, K., Irino, T., Itaki, T., Karasuda, A., Kinsley, C.W., Kubota, Y., Lee, G.S., Lee, K.E., Lofi, J., Lopes, C.I.C.D., Peterson, L.C., Saavedra-Pellitero, M., Sagawa, T., Singh, R.K., Sugisaki, S., Toucanne, S., Wan, S., Xuan, C., Zheng, H., and Ziegler, M., 2015. Site U1423. In Tada, R., Murray, R.W., Alvarez Zarikian, C.A., and the Expedition 346 Scientists, Proc. IODP, 346: College Station, TX (Integrated Ocean Drilling Program). doi:10.2204/iodp.proc.346.104.2015

'Expedition 346 Scientists' addresses.

\section{Background and objectives}

Integrated Ocean Drilling Program (IODP) Site U1423 is in the northeastern part of the marginal sea surrounded by the Japanese Islands, the Korean Peninsula, and the Eurasian continent at $41^{\circ} 41.95^{\prime} \mathrm{N}, 139^{\circ} 4.98^{\prime} \mathrm{E}$ and 1785 meters below sea level. The site is $\sim 130 \mathrm{~km}$ south of Ocean Drilling Program (ODP) Site 796 and $\sim 100 \mathrm{~km}$ northwest of the entrance of the Tsugaru Strait (Fig. F1). Site U1423 is situated on a terrace on the middle of the slope from Oshima Island, a small volcanic island $30 \mathrm{~km}$ to the southeast. The site is under the direct influence of the Tsushima Warm Current (TWC) that flows further north beyond the Tsugaru Strait toward the Soya Strait (Yoon and Kim, 2009). Because the sill depth of the Soya Strait is only $55 \mathrm{~m}$, the influence of the TWC on the site should have been significantly affected by glacioeustatic sea level changes during the Quaternary. Although Site U1423 is relatively close to Site 796, the tectonic setting of the two sites seems different. Site 796 has been directly influenced by west-east compression caused by incipient subduction along the nearby plate boundary between the North American and Eurasian plates (Tada, 1994). In contrast, Site U1423 seems less influenced by this compression because seismic profiles suggest conformable deposition for at least for the last $\sim 5 \mathrm{~m}$.y. (upper $300 \mathrm{~m}$ of sediment). Relatively low linear sedimentation rates (LSRs) are anticipated based on results from the site survey. The rates are likely to be low enough to detect the contribution of eolian dust from the Asian continent. Analyses of a site survey core confirm occasional dropstones in the upper $150 \mathrm{~m}$ of the sequence, suggesting its appropriateness for studies of ice-rafted debris (IRD).

Site U1423 is the middle site of the northern half of the latitudinal transect targeted by IODP Expedition 346 and is also the middle depth site of the depth transect. The location of Site U1423 in the northern part of the marginal sea was selected to identify the spatial extent of IRD events and their temporal variations. Because sea ice formation in this marginal sea occurred along its northwestern margin as a result of strong winter cooling by the East Asian winter monsoon (EAWM) wind (Talley et al., 2003), we expected the intensity of the IRD events to reflect the strength of the EAWM. At Site U1423, we hoped to reconstruct the EAWM intensity through examination of IRD abundance and distribution along the northern latitudinal transect in the marginal sea. Because stronger EAWM wind produces deep water, called Japan Sea 
Proper Water (JSPW), through sea ice formation in the northwestern part of the sea (Talley et al., 2003), sea ice formation and deepwater ventilation could also reflect EAWM intensity.

Because of the relatively shallow water depth of Site U1423, calcareous microfossils were expected to be better preserved than at the other sites in the Japan Basin. Planktonic microfossils may allow us to study the nature and strength of the influx of the TWC through the Tsushima Strait and/or the intensity of winter cooling, whereas study of benthic microfossils may allow us to discern the nature of the deep water (e.g., oxygenation, saturation level with respect to $\mathrm{CaCO}_{3}$, temperature, and salinity). Examination of the relation between surface water and deepwater characteristics may allow us to explore the linkage between the nature of the TWC and deepwater ventilation. Furthermore, comparison of $\mathrm{CaCO}_{3}$ burial flux and its temporal changes at this site to those at IODP Site U1422 will allow us to reconstruct behavior of the calcium carbonate compensation depth.

Site U1423 is also appropriate for reconstruction of eolian dust flux, sediment grain size, and provenance changes since $5 \mathrm{Ma}$, considering the relatively low expected LSR. Although only a slight contribution of IRD to the total terrigenous flux may be expected, the specific grain size range $(4-32 \mu \mathrm{m})$ may be used to differentiate the eolian dust component from other terrigenous components, including IRD.

\section{Operations}

Three holes were drilled at Site U1423 (proposed Site JB-2) (Table T1; see also Fig. F2 in the "Expedition 346 summary" chapter [Tada et al., 2015a]). Hole U1423A was cored using the advanced piston corer (APC) to $206.6 \mathrm{~m}$ core depth below seafloor (CSF-A) (see the "Methods" chapter [Tada et al., 2015b]). Similarly, Hole U1423B was cored with the APC to $249.1 \mathrm{~m}$ CSF-A. Hole U1423C was drilled without coring to $114 \mathrm{~m}$ CSF-A. From this depth to $180 \mathrm{~m}$ CSF-A, we cut and recovered six cores in a series of alternating drilled and cored intervals with the objective of filling gaps in APC cores recovered from the previous two holes. Real-time stratigraphic correlation indicated that the carefully orchestrated coring operation appeared to be successful. Downhole measurements were carried out in Hole U1423B using a modified version of the triple combination (triple combo) tool string (paleo combo) and the Formation MicroScanner (FMS)-sonic tool string. A total of 56 cores were required to obtain $502.6 \mathrm{~m}$ of sediment (105.2\% recovery).

\section{Transit from Site U1422}

The transit to Site U1423 was very short, and the 125 $\mathrm{nmi}$ distance was covered uneventfully in $12 \mathrm{~h}$ at an average speed of $10.4 \mathrm{kt}$. The sea passage ended at $2342 \mathrm{~h}$ on 21 August 2013. The vessel was maneuvered over the location coordinates, control of the vessel was turned over to dynamic positioning at $0030 \mathrm{~h}$ on 22 August, and a seafloor positioning beacon was deployed at $0215 \mathrm{~h}$ the same day.

\section{Hole U1423A}

Operations in Hole U1423 started on 22 August 2013. The same three-stand APC/extended core barrel (XCB) bottom-hole assembly used at the previous site was deployed, and the drill string was lowered to 1774 meters below rig floor (mbrf). After picking up the top drive and spacing out the drill string, an APC core barrel was deployed at $0530 \mathrm{~h}$ on 22 August. The bit was positioned at 1784.4 mbrf for the mudline core; however, the driller was unable to pressure up the drill string. Suspecting that the shear pins had prematurely failed during deployment, the barrel was recovered to the rig floor, where it was discovered empty and with all shear pins sheared. The pins were replaced, and the bit was lowered $10 \mathrm{~m}$ to 1794.4 mbrf for a second attempt. Hole U1423A started at $0640 \mathrm{~h}$ on 22 August. Core 346-U1423A$1 \mathrm{H}$ was recovered with $7.26 \mathrm{~m}$ of core, establishing a seafloor depth of 1796.6 mbrf. Cores $1 \mathrm{H}$ through $22 \mathrm{H}$ were taken from 0 to $206.6 \mathrm{~m}$ CSF-A and recovered $212.9 \mathrm{~m}$ of core (103\%). Four temperature measurements were taken using the advanced piston corer temperature tool (APCT-3) temperature shoe on Cores $4 \mathrm{H}, 7 \mathrm{H}, 10 \mathrm{H}$, and $13 \mathrm{H}(35.8,64.3,92.8$, and $121.3 \mathrm{~m}$ CSF-A, respectively). With the top drive left in place, the drill string was pulled clear of the seafloor at $2355 \mathrm{~h}$ on 22 August, ending Hole U1423A.

\section{Hole U1423B}

The ship was offset $15 \mathrm{~m}$ north of Hole U1423A and the bit was positioned at 1791.4 mbrf. Hole U1423B was spudded at $0050 \mathrm{~h}$ on 23 August 2013. Core 346U1423B-1H was recovered with $4 \mathrm{~m}$ of core, establishing a seafloor depth of 1797 mbrf. Cores $1 \mathrm{H}$ through $28 \mathrm{H}$ extended to $249 \mathrm{~m} \mathrm{CSF-A}$ and recovered $250 \mathrm{~m}$ of core $(100 \%)$. The recovery amount was negatively impacted because of zero recovery for Core $18 \mathrm{H}$ (151.6-158.1 m CSF-A), the result of a space-out error on the rig floor, resulting in an inadvertent drilling of hole that was to be cored on the next core. APC overpull (using full-length core barrels) varied between 60,000 and $80,000 \mathrm{lb}$ between 142 and $249 \mathrm{~m}$ CSF-A (Cores $17 \mathrm{H}$ through $28 \mathrm{H}$ ), 
with the exception of Core 27H (230.1-239.6 mbrf), when overpull reached $100,000 \mathrm{lb}$. The last core on deck was recovered at $1530 \mathrm{~h}$.

To prepare for downhole logging, the hole was circulated clean, the logging tools were moved forward to the rig floor, the top drive was set back, and the drill string was pulled to a logging depth of 80.0 meters below seafloor (mbsf). The paleo combo tool string was deployed and recorded spectral gamma ray, caliper, magnetic susceptibility, resistivity, and lithologic density logs. The second string consisted of the FMSsonic tool string, which recorded resistivity images of the borehole, sonic velocity, caliper, and natural gamma radiation (NGR) data over the entire interval. Both logging tool strings were able to reach total hole depth. The logging tools were then rigged down, and the drill string was pulled clear of the seafloor at $0515 \mathrm{~h}$ on 24 August. This marked the end of Hole U1423B.

\section{Hole U1423C}

The ship was offset $15 \mathrm{~m}$ south of Hole U1423A, and Hole U1423C was spudded at 0655 h on 24 August 2013. The operations plan for this hole was altered to save time and allow for recovering a few gaps in the stratigraphic record remaining after coring Holes U1423A and U1423B. The hole was drilled without coring (using an XCB center bit) to $114 \mathrm{~m}$ CSF-A. At that depth, APC coring commenced, recovering six cores interspersed with appropriate drilled intervals to properly space out the core breaks and cover the areas of interest. Hole U1423C was terminated at $180.5 \mathrm{~m}$ CSF-A. After setting back the top drive, the bit cleared the seafloor at $1700 \mathrm{~h}$ and was back on the rig floor at $2040 \mathrm{~h}$. The positioning beacon was recovered aboard at $1756 \mathrm{~h}$ while tripping the drill string. After breaking out the bit and nonmagnetic drill collar, the rig floor was secured for transit, thrusters/hydrophones were raised, and the sea passage to IODP Site U1424 began at $2136 \mathrm{~h}$.

\section{Lithostratigraphy}

Drilling at Site U1423 penetrated to a maximum subbottom depth of $249.1 \mathrm{~m}$ in Hole U1423B, recovering a total of $250 \mathrm{~m}$ of sediment for a recovery rate of $100 \%$. The shipboard lithostratigraphic program involved detailed visual assessment of sediment composition, color, sedimentary structures, and bioturbation intensity, supplemented by petrographic analysis of smear slides and bulk mineralogic analysis by X-ray diffraction (XRD). These were used to describe and define facies and facies associations in each hole. A total of 61 smear slides from Hole U1423A, 66 smear slides from Hole U1423B, and 12 smear slides from Hole U1423C were made and examined to help determine lithologic names. A total of 25 samples were selected for XRD analysis. The major characteristics of the sedimentary sequence at Site U1423 are summarized in Figures F2, F3, and F4, and the stratigraphic correlation between the three holes is shown in Figure F5.

The sedimentary succession recovered at Site U1423 extends from the Pliocene to Holocene and is dominated by clay, silty clay, and diatom ooze with discrete foraminifer-bearing clay levels. Volcaniclastic material represents a minor component throughout the sediment succession, except in tephra layers where it is the dominant component.

The section is divided into two major lithologic units (I and II), distinguished on the basis of sediment composition, referring particularly to the biosiliceous fraction content. Unit I is further divided into two subunits based on the occurrence of alternating dark and light color variations and the intensity of bioturbation. The character of the sediment physical properties, including NGR, magnetic susceptibility, color reflectance parameters, and density, records the distribution of the various sediment components and lithologies (see "Physical properties").

\section{Unit I}

Intervals: 346-U1423A-1H-1, $0 \mathrm{~cm}$, to $12 \mathrm{H}-1,105$ $\mathrm{cm} ; 346-\mathrm{U} 1423 \mathrm{~B}-1 \mathrm{H}-1,0 \mathrm{~cm}$, to $12 \mathrm{H}-3,140 \mathrm{~cm}$

Depths: Hole U1423A = 0-103.35 m CSF-A; Hole $\mathrm{U} 1423 \mathrm{~B}=0-103.50 \mathrm{~m}$ CSF-A

Age: Holocene to early Pleistocene (2.2 Ma)

\section{Lithologies and structures}

Unit I consists of Holocene to early Pleistocene silty clay and clay with lesser amounts of diatom-bearing and diatom-rich silty clay, as well as rare calcareous layers containing abundant foraminifers. Discrete tephra (volcanic ash) layers ranging in thickness from a few millimeters to $>10 \mathrm{~cm}$ are numerous. The total thickness of tephra layers in each core (Fig. F6; Table T2) reaches a broad maximum in lower Subunit IA but with high thickness totals also recorded in discrete intervals of Subunits IIA and IIB. Pyrite can be found as a minor component in most lithologies, whereas fine-grained tephra occurs as a dispersed component throughout much of the section based on smear slide analysis. Unit I is characterized primarily as representing fine-grained material derived from terrigenous sources.

Color banding suggested to be related to variable content of organic matter and pyrite are the most diagnostic features of Unit I, with dark, organic-rich intervals (dark gray to dark olive-gray) interspersed 
between lighter colored, organic-poor intervals (light green to light greenish gray). The relative frequency of these color alternations as well as the intensity of bioturbation are the criteria used for recognizing and distinguishing between Subunits IA and IB.

\section{Bulk mineralogy}

The results of XRD analysis are listed in Table T3. In general, Pliocene-Pleistocene sediment at this site is composed mainly of quartz, plagioclase, and clay minerals (including smectite, illite, and kaolinite and/or chlorite), as well as biogenic opal-A and minor amounts of halite and pyrite. Calcite (mostly foraminifers and nannofossils) is present in the upper $46 \mathrm{~m}$ of Unit I, reaching a maximum at $36.71 \mathrm{~m} \mathrm{CSF}$ A in Hole U1423A.

Figure F7 shows the downhole variations in peak intensity of the identified minerals at Site U1423. In general, the contents of quartz, plagioclase, smectite, illite, and kaolinite and/or chlorite show a long-term trend toward increasing counts toward the top of the sequence. In general, the peak heights of these minerals are higher within Unit I and typically lower in Unit II. In contrast, K-feldspar generally increases uphole throughout Unit II and Subunit IB but then fluctuates markedly in Subunit IA sediment, with several pronounced minima where K-feldspar contents drop to near zero. Peaks of opal-A are generally much lower in Unit I and higher in Unit II. The peak intensity of pyrite at $2.5 \mathrm{~m}$ CSF-A in Hole U1423A is very high. Halite, presumably precipitated from pore water, is present in all samples with higher intensities in Unit II and lower intensities in Unit I.

\section{Subunit IA}

Intervals: 346-U1423A-1H-1, $0 \mathrm{~cm}$, to $9 \mathrm{H}-6,135$ $\mathrm{cm} ; 346-\mathrm{U} 1423 \mathrm{~B}-1 \mathrm{H}-1,0 \mathrm{~cm}$, to $10 \mathrm{H}-2,136 \mathrm{~cm}$

Depths: Hole U1423A $=0-82.65$ m CSF-A; Hole $\mathrm{U} 1423 \mathrm{~B}=0-82.92 \mathrm{~m}$ CSF-A

Age: Holocene to early Pleistocene (1.8 Ma)

\section{Lithology and structures}

Subunit IA is primarily recognized by having a much higher frequency of dark layers (Fig. F8). It is also characterized by low $\mathrm{L}^{*}, \mathrm{a}^{*}$, and $\mathrm{b}^{*}$ values in color reflectance and high NGR values with significant fluctuations. Subunit IA is composed mainly of silty clay and clay with subordinate amounts of diatomaceous clay and foraminifer-bearing silty clay. Bioturbation is moderate to intense throughout this subunit and is most noticeably observed at the interface between lighter colored intervals and darker colored beds. Two types of dark intervals can be recognized based on the color shade. Somewhat lighter brown layers are affected by slight bioturbation at various levels, which possibly hides any original lamination. Dark brown layers, on the other hand, typically show fine parallel lamination, frequently highlighted by the presence of biogenic carbonate (mostly planktonic foraminifers), which is light in color and visible to the naked eye. The lower contact of the darker brown layers is typically sharp, whereas the upper contact often appears to be gradual at the transition to the light gray-greenish bed. In some cases, the opposite pattern is observed where the top contact of a dark brown layer is sharp and the dark color fades gradually downhole (see Fig. F8, Section 346U1423B-5H-3 for examples).

Among the dark colored layers, a very dark greenish brown bed is observed in interval 346-U1423B-5H-6, $30-123 \mathrm{~cm}$. It appears to be different compared to other dark colored beds because of its considerable thickness $(\sim 100 \mathrm{~cm})$ and very dark color. This interval is finely laminated with marked color banding (very dark gray and lighter gray alternation) visible in its upper portion. A peculiar characteristic of the very dark greenish interval at 346-U1423B-5H-6, 30$123 \mathrm{~cm}$, is that it contains abundant small pyrite framboids (see "Composition") distributed throughout the layer, which is otherwise composed of terrigenous components and clay minerals. Diatoms and sponge spicules are abundant in this layer, but no biogenic carbonate is found.

Tephra layers are a minor but common component in Subunit IA. An especially prominent tephra layer is found in interval 346-U1423B-8H-4, 50-60 cm. This $10 \mathrm{~cm}$ thick tephra is fine grained and white in color and consists of silt-sized volcanic glass and crystals. The volcanic glass contains semiregular shapes with sharp borders on the fragments mixed with rectangular, subparallel pipe vesicles. The volcanic material does not show any trace of postdepositional alteration.

\section{Composition}

The principal lithologic components in Subunit IA are terrigenous, volcanic, and biogenic in origin (see Site U1423 smear slides in "Core descriptions"). Diatoms dominate the biogenic fraction, with a minor component of calcareous microfossils, mostly foraminifers and nannofossils (Fig. F9).

Terrigenous components in this subunit are dominated by clay and fine silty clay fractions. Volcanic glass and pumice account for nearly $100 \%$ of the tephra layers.

In the upper part of Subunit IA, the light greenish gray intervals are mostly composed of siliciclastic fine-grained material (up to 80\%) dominated by clay minerals. A very low biogenic component is ob- 
served. Conversely, the dark brown laminated beds are relatively rich in biosiliceous microfossils and biogenic carbonates. Planktonic foraminifers are observed, but the biogenic carbonate fraction is estimated to be no greater than $20 \%$.

\section{Subunit IB}

Intervals: $346-\mathrm{U} 1423 \mathrm{~A}-9 \mathrm{H}-6,135 \mathrm{~cm}$, to $12 \mathrm{H}-1$, $105 \mathrm{~cm}$; 346-U1423B-10H-2, $136 \mathrm{~cm}$, to $12 \mathrm{H}-3$, $140 \mathrm{~cm}$

Depths: Hole U1423A $=82.65-103.35$ m CSF-A; Hole U1423B $=89.92-103.50 \mathrm{~m}$ CSF-A

Age: early Pleistocene (1.8-2.2 Ma)

\section{Lithology and structures}

Subunit IB sediment is dominated by silty clay that contains variable amounts of biosiliceous material (mostly diatoms and siliceous sponge debris). The frequency of the dark and light color alternation is considerably less pronounced than in Subunit IA (Fig. F10). Bioturbation increases gradually with depth, and sediment mottling and disruption of laminae and color banding is more prevalent. A subtle decrease in NGR values in Subunit IB sediment suggests decreasing amounts of organic matter and/ or clay mineral content relative to Subunit IA.

\section{Composition}

The principal lithologic components in Subunit IB are terrigenous, volcanic, and biogenic materials (see Site U1423 smear slides in "Core descriptions"). The major difference between lithologies of Subunits IA and IB is the less frequent occurrence of calcareous microfossils and slightly greater contents of the biosiliceous component (mostly diatoms and sponge spicules) in Subunit IB than in Subunit IA. In Subunit IB, terrigenous materials are the major component $(>80 \%)$ of the sediment, and they are dominated by clay and fine silty clay fractions. The biogenic fraction is generally low $(<10 \%)$ in Subunit IB and is dominated by diatoms and sponge spicules with fewer calcareous microfossils (mostly rare nannofossils). Volcanic glass usually occurs as a minor dispersed component ( $5 \%)$ throughout the sections.

\section{Unit II}

Intervals: $346-\mathrm{U} 1423 \mathrm{~A}-12 \mathrm{H}-1,105 \mathrm{~cm}$, to $22 \mathrm{H}-7$, $66 \mathrm{~cm} ; 346-\mathrm{U} 1423 \mathrm{~B}-12 \mathrm{H}-3,140 \mathrm{~cm}$, to $28 \mathrm{H}-\mathrm{CC}$, $22 \mathrm{~cm}$

Depths: Hole U1423A = 103.35-206.76 m CSF-A; Hole U1423B = 103.50-249.52 m CSF-A

Age: early Pleistocene (2.2 Ma) to Pliocene $(<3.9$ Ma)

\section{Lithology and structures}

Unit II is dominantly composed of moderate to heavily bioturbated diatomaceous silty clay and clay and diatom ooze. Unit II is distinguished from Unit I on the basis of a significant increase in diatom content relative to terrigenous sediment from top to bottom. Color banding is less common in Unit II than in Unit I and nearly disappears in the lowest part of the unit. Sediment of Unit II is moderately to heavily bioturbated and often shows a mottled facies (Figs. F11, F12).

In contrast to Site U1422, turbidites are rarely observed in Unit II sediment at this site. Tephra beds are frequently found in Subunit IIB (Table T2), but their numbers decrease significantly downhole even if single beds are generally much thicker than in Unit I. Rare but thick tephra deposits strongly contribute to the total thickness peaks of tephra in Unit II (Table T2; Fig. F6).

\section{Composition}

The major lithologies in Unit II are dominated by fine-grained material (see Site U1423 smear slides in "Core descriptions"). In Core 346-U1423A-10H and $11 \mathrm{H}$ smear slides of Subunit IB, the dominant finegrained component is clay sized, in which abundant clay minerals and quartz are commonly found. Biosiliceous components are present in these cores but occur in low abundances (5\%-10\%). Biosilica rapidly becomes more abundant ( $>70 \%)$ in smear slides from Core $12 \mathrm{H}$ downhole, and this increase is adopted as the boundary between Unit I and II sediments. Diatoms and siliceous sponge spicules dominate the biosilica fraction in Unit II, whereas radiolarians and silicoflagellates are found only in rare or trace amounts (1\%-5\%). The above-mentioned siliceous fossil assemblages are observed both in the brownish and greenish colored sediment in the "diatom ooze" category.

Dispersed pyrite is found mostly in brownish intervals, but the total amount of pyrite (framboids and/ or irregular masses) and other opaque minerals is not particularly abundant $(<5 \%)$ except in one dark layer found at Section 346-U1423A-12H-4, $2 \mathrm{~cm}$. Here, pyrite is abundant ( $10 \%$ of the bulk sediment).

Tephra layers that are several centimeters thick were found in Unit II. The volcaniclastic layer found in interval $346-\mathrm{U} 1423 \mathrm{~A}-8 \mathrm{H}-7,46-48.5 \mathrm{~cm}$, is unusual. It shows normal grading, and the bottom layer $(4 \mathrm{~mm})$ yields coarse sand-sized pyroclastic material (interpreted to be ballistic debris from eruptions), which is opaque under transmitted light microscope analyses. Another noteworthy tephra is observed in interval $20 \mathrm{H}-6,74-93 \mathrm{~cm}$. This volcanic deposit is coarse 
grained (sand size) and contains abundant biotite flakes and bubble-wall shards with cuspate and lunate forms (Fig. F13). In general, tephra beds consist of pristine volcanic glass shards.

\section{Bulk mineralogy}

The results of XRD analyses conducted on Hole U1423C sediment are listed in Table T3. In general, the bulk mineral assemblage of Unit II sediment is similar to that of Unit I. The major difference is the higher opal-A peak intensities and the disappearance of the calcite peak in samples of Unit II. Figure F7 indicates a slight downhole decrease in quartz, plagioclase, illite, kaolinite and/or chlorite, and pyrite contents, countered by the significant increase in opal-A and halite.

\section{Subunit IIA}

Intervals: $346-\mathrm{U} 1423 \mathrm{~A}-12 \mathrm{H}-1,105 \mathrm{~cm}$, to $14 \mathrm{H}-1,0$ $\mathrm{cm} ; 346-\mathrm{U} 1423 \mathrm{~B}-12 \mathrm{H}-3,140 \mathrm{~cm}$, to $14 \mathrm{H}-2,118$ $\mathrm{cm}$

Depths: Hole U1423A = 103.35-121.30 m CSF-A; Hole U1423B = 103.50-120.78 m CSF-A

Age: early Pleistocene to late Pliocene (2.2-3.0 Ma)

Unit II is divided into two subunits (IIA and IIB) with Subunit IIA considered to be somewhat transitional between the silty clay of Unit I and the ubiquitous diatom ooze of Subunit IIB. Subunit IIA consists of diatom-rich clay (Fig. F11), but compared to Subunit IIB, the siliciclastic fraction still remains dominant. NGR values in Subunit IIA gradually decrease with respect to Unit I as the biosiliceous component rises but the values remain highly variable (Fig. F14).

\section{Subunit IIB}

Intervals: 346-U1423A-14H-1, $0 \mathrm{~cm}$, to $22 \mathrm{H}-7,66$ $\mathrm{cm}$; $346-\mathrm{U} 1423-14 \mathrm{H}-2,118 \mathrm{~cm}$, to $28 \mathrm{H}-\mathrm{CC}, 22$ $\mathrm{cm}$

Depths: Hole U1423A $=121.30-206.76$ m CSF-A; Hole U1423B = 120.78-249.52 m CSF-A

Age: late Pliocene (>3.0 Ma)

Subunit IIB is composed of diatom ooze and clayey diatom ooze (Fig. F12). The abundance of diatoms and other siliceous components is uniformly high throughout Subunit IIB (90\% and above) and is recorded by reduced variability and a significant decrease in NGR values. The siliciclastic fraction is a minor component and usually includes abundant clay minerals and rare quartz fragments. It may be mixed with vitric tephra and sparse pyrite. Bioturbation is moderate to intense, and distinctive mottling is displayed in some sections.

\section{Discussion}

Overall, the sedimentary succession at Site U1423 records a history of terrigenous and biosiliceous deposition since the Pliocene. Unit II sediment, which is late Pliocene to early Pleistocene in age, is characterized by dominantly diatom rich strata, as compared to Unit I, possibly corresponding to a period of elevated biological productivity and good overall circulation in the basin. In contrast to the counterpart Unit II sediment at Site U1422, no turbidites were identified at this site. This lack of turbidite deposits at Site U1423 has allowed further division of Unit II sediment into Subunits IIA and IIB, which extends beyond the original lithostratigraphy described at nearby ODP Site 794 (Tamaki, Pisciotto, Allan, et al., 1990; Tada and Iijima, 1992; Tamaki et al., 1992; Tada, 1994). Tada and Iijima (1992) and Tada (1994) later refined and completed the lithostratigraphy of sedimentary units recognized at Site 794, but nonetheless retained only a single, undifferentiated Unit II.

Visually, there is no clear characteristic allowing straightforward division of Unit II into Subunits IIA and IIB, but the decrease in NGR values at the transition between Units I and II and the further decline at the top of Subunit IIB appear to be significant. This decrease is mainly due to a drop in uranium content and thus probably reflects the overall decrease in organic matter content (Fig. F14) in Unit II (see "Geochemistry"). However, the decrease in organic matter is itself accompanied by a concomitant increase in diatom content, which suggests that the low NGR values in Unit II are driven by dilution from the high input and accumulation of biogenic opal. The siliceous biogenic component remains relatively low in the transitional Subunit IIA except for a very few horizons, whereas Subunit IIB mainly comprises of diatom ooze.

The occurrence of authigenic pyrite is frequent throughout the sediment succession and is found most abundantly in the brownish and dark brown layers in both Units I and II. The size and distribution of this mineral is of great interest for determining the transition from oxic to suboxic/euxinic conditions in the basin, as well as the water column stratification. Pyrite is ubiquitous in modern anoxic sediment and preserved in many ancient sediment rocks. Small $(<10 \mu \mathrm{m})$ scattered framboids can be considered a reliable marker of low oxygen conditions within the water column (Wilkin et al., 1996, 1997; Wilkin and Arthur, 2001), as previously observed in dark layers deposited during the last glacial in the marginal sea (Masuzawa and Kitano, 1984). On the other hand, the diagenetic pyrite is com- 
monly found in discrete layers (few millimeters thick) and is composed of larger $(\sim 100 \mu \mathrm{m})$, sometimes euhedral, crystals.

More than 100 visible tephra beds were observed in cores from Hole U1423A (Table T2). The thickest tephra layer (maximum thickness $=17 \mathrm{~cm}$ ) occurs in Subunit IIB, although most of the layers were $<1 \mathrm{~cm}$ thick. The total thickness of tephra layers in each core shows a peak in the transition from the lower part of Subunit IA to Subunit IB (Fig. F6). Tephra occurrence decreased remarkably in Unit II, although a few thick tephra deposits strongly contribute to the total thickness peaks in Unit II. Some especially distinctive tephra beds were observed. One is a thick white tephra found at 45.41-45.57 m CSF-A in Hole U1423A (interval 346-U1423A-6H-1, 11-27 cm). This tephra contains abundant thin bubble-wall type volcanic glass shards. The distinctive glass morphology suggests that this layer may be correlative to the Hakkoda-Daiichi (Hkd-1 or Hkd-Ku) tephra erupted from Hakkoda Volcano in northern Honshu, Japan. This tephra occurs just above the Brunhes/Matuyama paleomagnetic boundary (Machida and Arai, 2003). Another characteristic tephra was found at 186.37-186.54 m CSF-A in Hole U1423A (interval $20 \mathrm{H}-6,77-94 \mathrm{~cm})$. This tephra is dominated by "bubble-junction" type glass shards with biotite as the dominant heavy mineral. These features are the same as in the Znp-Ohta tephra that occurs in central Honshu, Japan (Satoguchi and Nagahashi, 2012). Another characteristic tephra was observed at 69.2969.395 m CSF-A in Hole U1423A (interval 8H-4, 49$59.5 \mathrm{~cm}$ ). This tephra consists of thick bubble-wall glass shards and biotite, as well as clinopyroxene and orthopyroxene as heavy minerals. One possible match for this tephra is the OM-SK110 tephra, which occurs in the Pliocene sequence above the Olduvai event in central Japan (Satoguchi and Nagahashi, 2012). These initial correlations will be further examined by shore-based research.

\section{Biostratigraphy}

At Site U1423, a $250 \mathrm{~m}$ thick succession of Pliocene to Holocene sediment was recovered. Calcareous nannofossils are generally rare and sporadically distributed in the upper $80 \mathrm{~m}$. Planktonic foraminifers are rare to absent with moderate to poor preservation throughout most of the succession but are abundant in the upper part of the succession above $74.19 \mathrm{~m}$ CSF-A. However, the regional zonal scheme only has limited application, as few planktonic foraminiferal datums were identified. Radiolarians are generally common to abundant with rare occurrences at $83.6 \mathrm{~m}$ CSF-A. The radiolarian biostrati- graphic zonation ranges from the Larcopyle pylomaticus Zone (Pliocene) to the Botryostrobus aquilonaris Zone (Late Pleistocene). The diatoms are well preserved with abundances ranging from $2 \%-5 \%$ to $>60 \%$. Diatom mats and oozes are found in the Pliocene samples. The diatom stratigraphy spans the interval from Zone NPD 7 (Pliocene) to NPD 12 (Late Pleistocene). The nannofossil, radiolarian, and diatom datums and zonal schemes generally agree, with only minor inconsistencies. The integrated calcareous and siliceous microfossil biozonation is shown in Figure F15, and microfossil datums are shown in Table T4. A preliminary age-depth plot including biostratigraphic datums is shown in Figure F16. See "Stratigraphic correlation and sedimentation rates" for a discussion on sedimentation rates at Site U1423. Benthic foraminifers occur intermittently throughout the succession, exhibiting marked changes in abundance, preservation, and species distribution. The overall assemblage composition indicates bathyal paleodepths. However, the assemblage composition also reflects substantial variations in organic export flux to the seafloor and deepwater oxygenation.

\section{Calcareous nannofossils}

Calcareous nannofossil biostratigraphy is based on the analysis of core catcher and split-core section samples from Holes U1423A-U1423C. Thirty of 76 samples studied at Site U1423 contain nannofossils (Table T5).

Nannofossils are present in Pleistocene sediment from 26.8 to $76.06 \mathrm{~m}$ CSF-A in Hole U1423A (Samples $346-\mathrm{U} 1423 \mathrm{~A}-4 \mathrm{H}-1,50-51 \mathrm{~cm}$, to $9 \mathrm{H}-2,75-76$ $\mathrm{cm})$ and from 28.10 to $77.36 \mathrm{~m}$ CSF-A in Hole U1423B (Samples 346-U1423B-4H-4, 53-54 cm, to 9H-5, 75-76 cm). Nannofossils are absent in Hole U1423A between 83.60 and $207.02 \mathrm{~m}$ CSF-A (Samples 346-U1423A-9H-CC to 22H-CC), with the exception of a short interval from 142.78 to $150.24 \mathrm{~m}$ CSF-A (Samples 16H-2, 98-99 cm, to 16H-CC), where rare to abundant nannofossils are observed (Fig. F17). These samples have been disturbed by drilling operations (see "Lithostratigraphy") and thus represent assemblages that are not in situ. Samples from Hole U1423B were barren below 82.87 m CSF-A (Sample 346-U1423B-10H-2, 130-131 cm) with the exception of a short interval containing rare nannofossils between 136.45 and $151.91 \mathrm{~m}$ CSF-A (Samples $16 \mathrm{H}-3,85-86 \mathrm{~cm}$, to $17 \mathrm{H}-\mathrm{CC})$. All samples from Hole U1423C are devoid of calcareous nannofossils.

Nannofossil diversity at Site U1423 is low, although it is higher than at previous Site U1422. The nannofossil assemblage consists of relatively few taxa including Braarudosphaera bigelowii, Calcidiscus lepto- 
porus, Calcidiscus macintyrei, Coccolithus pelagicus, Emiliania huxleyi, Gephyrocapsa caribbeanica, Gephyrocapsa muellerae, Gephyrocapsa oceanica, Gephyrocapsa spp. $(>4 \mu \mathrm{m})$, Gephyrocapsa spp. $(<4 \mu \mathrm{m})$, Helicosphaera carteri, Helicosphaera spp., Pontosphaera japonica, Pontosphaera multipora, Pontosphaera spp., Pseudoemiliania lacunosa, Reticulofenestra minuta, Reticulofenestra minutula, Reticulofenestra spp., and Syracosphaera spp. Helicosphaera sellii is present in the disturbed interval (Sample 346-U1423A-16H-2, 98-99 cm; $142.79 \mathrm{~m}$ CSF-A), and Cyclicargolithus floridanus is documented as a reworked species in Samples 6H-2, 94-95 cm, and $6 \mathrm{H}-\mathrm{CC}$. Preservation is generally poor to moderate with sporadic occurrences of good preservation in samples with high nannofossil abundances (e.g., Sample 4H-4, 92-93 cm; $31.68 \mathrm{~m}$ CSF-A), composed almost entirely of small Gephyrocapsa $(<4 \mu \mathrm{m})$.

Two nannofossil zones are recognized (Fig. F15). Nannofossil Zones CN15/NN21 are recognized based on the first occurrence (FO) of E. huxleyi (Sample 346-U1423B-2H-4, 69-70 cm; $9.29 \mathrm{~m}$ CSF-A), and the bases of nannofossil Zones CN14b/NN20 are recognized based on the last occurrence (LO) of P. lacunosa (Sample 346-U1423A-5H-1, 113-114 cm; 36.93 m CSF-A).

\section{Radiolarians}

A total of 29 core catcher samples from Holes U1423A (Samples 346-U1423A-1H-CC to 22H-CC) and U1423B (Samples 346-U1423B-22H-CC to 28HCC) were prepared for radiolarian analysis (Table T6). Radiolarians are generally common to abundant in the entire succession (Fig. F17), although they are rare at 83.6 m CSF-A (Sample 346-U1423A-9H-CC).

Nine radiolarian datums were found in Hole U1423A (Table T4). Late Pleistocene datums, the LOs of Lychnocanoma sakaii (0.05 Ma), Amphimelissa setosa (0.08 $\mathrm{Ma})$, and Spongodiscus sp. (0.29 Ma), are observed at $7.2 \mathrm{~m}$ CSF-A (Sample 346-U1423A-1H-CC), $17.0 \mathrm{~m}$ CSF-A (Sample 2H-CC), and 26.6 m CSF-A (Sample $3 \mathrm{H}-\mathrm{CC})$, respectively. The LO of Axoprunum acquilonium (2.2 Ma) is at $93.2 \mathrm{~m} \mathrm{CSF-A} \mathrm{(Sample} \mathrm{10H-CC)}$ just below the sparse interval at $83.6 \mathrm{~m}$ CSF-A (Sample 9H-CC). The Pleistocene/Pliocene boundary is close to the FO of Cycladophora davisiana (2.7 Ma) at 112.1 m CSF-A (Sample 12H-CC) and the LO of Hexacontium parviakitaensis $(2.7 \mathrm{Ma})$ at $131.2 \mathrm{~m}$ CSF-A (Sample 14H-CC). The FO of H. parviakitaensis (3.9/ $4.3 \mathrm{Ma}$ ) was found at $168.9 \mathrm{~m} \mathrm{CSF}-\mathrm{A}$ (Sample 18HCC). Deeper than 178.3 m CSF-A (Sample 19H-CC), the Siphocampe arachnea group shows an acme zone (4.46-4.71 Ma). The FO and LO of Dictyophimus bullatus are primary datums that define the top and base of the Dictyophimus bullatus Zone. Although this species is very rare, the LO and FO datums are recog- nizable at $187.7 \mathrm{~m}$ CSF-A (Sample 20H-CC) and 197.2 m CSF-A (Sample 21H-CC). The abundant occurrence of the $S$. arachnea group in the absence of D. bullatus at the base of Hole U1423A (207.0 m CSFA; Sample 22H-CC) suggests an age between 4.4 and 4.71 Ma.

In the lower part of Hole U1423B, two radiolarian datums, the LO of D. bullatus $(4.4 \mathrm{Ma})$ and a rapid increase (RI) of the $S$. arachnea group $(4.71 \mathrm{Ma})$, are at 192.3 m CSF-A (Sample 346-U1423B-22H-CC) and $220.8 \mathrm{~m}$ CSF-A (Sample 25H-CC), respectively (Table T4). The base of Hole U1423B (249.5 m CSF-A; Sample $28 \mathrm{H}-\mathrm{CC})$ is deeper than the RI of the $S$. arachnea group (4.71 Ma) and shallower than the LO of Larcopyle pylomaticus, suggesting an age younger than 5.3 Ma.

\section{Diatoms}

Diatom biostratigraphy was based on smear slides from core catcher samples. Twenty-two core catcher samples were examined from Hole U1423A (Samples 346-U1423A-1H-CC to 22H-CC), and five NPD datums were identified (Tables T4, T7):

- The LO of Proboscia curvirostris (older than $0.3 \mathrm{Ma}$ ) marks the base of NPD 12 (Sample 4H-CC).

- The LO of Actinocyclus oculatus (older than 1.0 Ma) marks the base of NPD 11 (Sample 6H-CC).

- The LO of Neodenticula koizumii (older than 2.0 Ma) marks the base of NPD 10 (Sample 8H-CC).

- The LO of Neodenticula kamtschatica (older than 2.6-2.7 Ma) marks the base of NPD 9 (Sample 9H$\mathrm{CC})$.

- The FO of N. koizumii (younger than 3.4-3.9 Ma) marks the base of NPD 8 (Sample 14H-CC).

Sample $22 \mathrm{H}-\mathrm{CC}$, which is younger than $5.6 \mathrm{Ma}$, is the deepest sample from Hole U1423A (LO of Shionodiscus oestrupii).

Ten core catcher samples were collected from Hole U1423B (Samples 346-U1423B-15H-CC to 17H-CC and $22 \mathrm{H}-\mathrm{CC}$ to $28 \mathrm{H}-\mathrm{CC}$ ), and two datums were identified (Tables T4, T7). The samples from Hole U1423B were collected to complement the observations from Hole U1423A because the base of Hole U1423B was deeper than in Hole U1423A. Therefore, the ages in samples from Hole U1423B define the following NPD zones: the FO of Neodenticula koizumii (younger than 3.4-3.9 Ma) marks the base of NPD 8 (Sample 16H-CC), and Sample 28H-CC (NPD 7) is younger than 4.81 Ma based on the LO of Thalassiossira jacksonii.

Overall, diatom abundance ranged from $2 \%-5 \%$ to $>60 \%$ in the observed smear slides (Fig. F17). Preservation was good in all samples, and there were no 
signs of dissolution. Diatom valve fragmentation was normal. In addition, the ratio between preserved $>50$ $\mu \mathrm{m}$ centrics and $<20 \mu \mathrm{m}$ pennates was constant. Diatom range abundance is shown in Table T7.

Diatom samples with abundance $>60 \%$ were identified in Samples 346-U1423A-8H-CC to $14 \mathrm{H}-\mathrm{CC}$, and diatom mats were identified in Samples 346U1423A-7H-CC, 13H-CC, 15H-CC, 20H-CC, and 21H-CC and 346-U1423B-23H-CC (Fig. F17). The comparison of these samples with qualitative abundances of Chaetoceros spores, an upwelling indicator, suggests different high-productivity systems: one dominated by Chaetoceros spores that is analogous to modern upwelling systems and a different one that produces diatom mats and oozes with lower Chaetoceros spore abundances.

Freshwater diatom species were absent in all samples except for rare occurrences in Samples 346-U1423A$5 \mathrm{H}-\mathrm{CC}$ and $6 \mathrm{H}-\mathrm{CC}$ (Table T7).

\section{Planktonic foraminifers}

Planktonic foraminifers were examined in core catcher samples from Holes U1423A (22 samples), U1423B (10 samples), and U1423C (6 samples) and in toothpick samples from Hole U1423A (8 samples) and U1423B (15 samples) taken after the core sections were split. Planktonic foraminifers are mainly confined to the upper part of the succession (shallower than Sample 346-U1423A-8H-CC; $74.19 \mathrm{~m}$ CSF-A) (Fig. F18). Of the 23 toothpick samples examined from dark layers (Table T8), 14 samples contained $>80$ specimens, 1 sample contained 22 specimens, and 2 samples had $<5$ specimens.

Taxon relative abundances and estimates of assemblage preservation are presented in Table T8. Planktonic foraminifers are abundant shallower than Sample 346-U1423A-6H-CC (54.96 m CSF-A) and are absent or rare in the interval deeper than Sample 7HCC (64.64 m CSF-A), except in Samples 346-U1423A16H-CC (150.20-150.24 m CSF-A), 346-U1423B15H-CC (132.80-132.85 m CSF-A), and 346-U1423C4H-CC (142.65-142.70 m CSF-A), where high abundance peaks occur. Preservation is moderate to good in most core catcher samples, and fragmentation and/or pyritization are common.

Site U1423 planktonic foraminiferal assemblages above Sample 346-U1423A-8H-CC (74.19 m CSF-A) are characteristic of cold, midlatitude, restricted environments, consisting mainly of Globigerina bulloides and Neogloboquadrina pachyderma (sinistral) with rare occurrences of Globigerina umbilicata, Globigerina quinqueloba, Neogloboquadrina pachyderma (dextral), Neogloboquadrina dutertrei (= Neogloboquadrina himiensis), Neogloboquadrina incompta, Neoglobo- quadrina kagaensis group (Neogloboquadrina kagaensis and Neogloboquadrina inglei), and Neogloboquadrina cf. asanoi. In addition to these species, Globorotalia praeinflata is common in Samples 346-U1423B-15HCC (132.80-132.85 m CSF-A) and 346-U1423C-4HCC (142.65-142.70 m CSF-A). N. pachyderma (dextral) is dominant in Sample 346-U1423A-16H-CC (150.20-150.24 m CSF-A), where rare specimens of Orbulina universa are also found. The LO of $N$. kagaensis group, reported as 0.7 Ma by Kucera and Kennett (2000), was identified in Sample 346-U1423A$5 \mathrm{H}-4 \mathrm{~W}, 77-78 \mathrm{~cm}$ (41.07-41.08 m CSF-A). The peak in planktonic foraminiferal abundance in Sample 346-U1423A-16H-CC (150.20-150.24 m CSF-A) corresponds to Zone PF6 of Maiya (1978), based on the co-occurrence of $O$. universa and $N$. pachyderma (dextral), indicating that this horizon is older than 3.0 Ma (Miwa, 2014).

\section{Benthic foraminifers}

Benthic foraminifers were examined in core catcher samples from Holes U1423A (22 samples), U1423B (10 samples), and U1423C (6 samples) and in toothpick samples from Holes U1423A and U1423B taken after cores were split. Mudline samples recovered in Holes U1423A and U1423B were also investigated. Samples with an average volume of $\sim 30 \mathrm{~cm}^{3}$ were processed from all core catchers to obtain quantitative estimates of downhole benthic foraminiferal distribution patterns. To assess assemblage composition and variability, all specimens from the $>150 \mu \mathrm{m}$ fraction were picked and transferred to slides prior to identification and counting. The distribution of benthic foraminifers was additionally checked in the 63$150 \mu \mathrm{m}$ fraction to ensure that assemblages in the $>150 \mu \mathrm{m}$ fraction were representative and that small species such as phytodetritus feeders or small infaunal taxa were not overlooked.

Benthic foraminifers occur intermittently through the $\sim 250 \mathrm{~m}$ thick biosiliceous-rich succession recovered at Site U1423 (Fig. F18; Table T9). Abundance and diversity are generally low, except for three samples (Table T9) found to contain at least 100 specimens per $30 \mathrm{~cm}^{3}$ of sediment and to exhibit much higher diversity. Preservation varies substantially throughout the succession. The assemblages consist of calcareous and agglutinated taxa, and their overall composition indicates bathyal paleodepths throughout the Pleistocene and Pliocene. Prominent variations in the downcore distribution of benthic foraminifers appear to reflect changes in organic export flux to the seafloor and/or in oxygenation at the seafloor (Fig. F18).

A total of 44 benthic foraminiferal taxa were identified. Census counts from core catcher and split-core 
section samples are presented in Table T9. Figure F18 summarizes the downcore distribution of the more common benthic foraminiferal taxa in core catcher samples from Holes U1423A-U1423C. Common species include Bolivina pacifica, Epistominella pulchella, Eggerella bradyi, Globobulimina pacifica, Martinotiella communis, and Miliammina echigoensis (Figs. F19, F20). In Samples 346-U1423A-4H-CC and 5H-CC, the high abundances of $B$. pacifica and E. pulchella suggest enhanced surface productivity and higher organic export flux during deposition. B. pacifica is an ectobiont-bearing foraminifer, which also displays cytoplasmic adaptations (plasma membrane invaginations) that are thought to promote inhabitation of microxic environments (trace or $0.1 \mathrm{~mL} / \mathrm{L}$; sensu Bernhard and Sen Gupta, 1999) (Bernhard et al., 2010). Thus, the dominance of this species in Sample 346U1423A-5H-CC indicates microxic pore water associated with intense oxygen depletion of bottom water during deposition of this sedimentary interval. Samples 346-U1423A-16H-CC (150.2 m CSF-A), 346U1423B-15H-CC (132.8 m CSF-A), and 346-U1423C4H-CC (142.65 m CSF-A) are characterized by a diverse assemblage indicating substantially improved oxygenation at the seafloor at $\sim 3$ Ma (Fig. F19). The assemblage includes cosmopolitan taxa such as Cibicidoides mundulus, Cibicidoides refulgens, Cibicidoides robertsonianus, Globobulimina pacifica, Hoeglundina elegans (which has an aragonitic test), Melonis barleanum, Melonis pompilioides, Pullenia quinqueloba, Oridorsalis umbonatus, and Pyrgo murrhina, as well as a few ostracods (see below). These intervals do not appear to be correlative, based on hole-to-hole stratigraphic correlation (see "Stratigraphic correlation and sedimentation rates"). They may, however, correspond to several transient episodes of improved deepwater circulation in the marginal sea, although the low resolution of our sample set does not allow resolution of individual events in Holes U1423AU1423C. Moderately to well-preserved diatoms and radiolarians are common to abundant in residues $>150$ and $>63 \mu \mathrm{m}$ throughout the succession and become dominant deeper than $100 \mathrm{~m}$ CSF-A. Most samples deeper than 100 m CSF-A, except for Samples 346-U1423A-16H-CC (150.2 m CSF-A), 346U1423B-15H-CC (132.8 m CSF-A), and 346-U1423C4H-CC (142.65 m CSF-A), are either barren or impoverished, mainly containing rare agglutinated species.

\section{Ostracods}

Core catcher samples were also examined for the presence of ostracods during shipboard preparation of benthic foraminifer samples. Ostracods are absent from all but Sample 346-U1423A-16H-CC (150.2 m CSF-A), where three valves and one carapace belonging to Krithe spp., one carapace of Henryhowella cf. $H$. circumdentata (Brady, 1880), and one valve of Legitimocythere sp. were found. Preservation of the shells ranges from moderate to very good (Fig. F21). This same assemblage was found previously at Site 435 in the Japan Trench during Deep Sea Drilling Project Leg 56 (Hanai et al., 1980). All three taxa are common in bathyal environments.

\section{Mudline samples}

Mudline samples from Holes U1423A and U1423B were gently washed in order to preserve fragile agglutinated specimens with extremely low fossilization potential. The mudline sample from Hole U1423A contains only organically cemented agglutinated foraminifers, including Cribrostomoides subglobosus, Haplophragmoides sphaeriloculum, Hyperammina elongata, Jacullela cf. acuta, Miliammina echigoensis, Paratrochammina challengeri, and Rhabdammina sp. (Fig. F20). These organically cemented tests are extremely delicate and fragile (except for M. echigoensis) and thus have virtually no fossilization potential. Only two specimens of M. echigoensis were stained with rose bengal. These specimens exhibit much better preservation than unstained specimens. Diatoms are dominant, and planktonic foraminifers are absent in the mudline sample, suggesting that planktonic calcareous tests may be dissolved and that unfavorable conditions prevent calcareous benthic foraminifers from inhabiting the upper few centimeters of the sediment.

\section{Geochemistry}

Site U1423 was the second of three sites drilled in the Japan Basin. Similar to Sites U1422 and U1424, the primary goal behind drilling was to generate high-resolution paleoceanographic records, especially including the history of eolian dust and IRD. However, the water depth $(1785 \mathrm{~m})$ and landward proximity of Site U1423 contrasts with those at the other two sites. Furthermore, the location of Site U1423 had not been previously drilled. In short, the sedimentary record and geochemical profiles were expected to be somewhat different from those at Sites U1422 and U1424, but we had limited information before operations.

The main focus of the geochemistry program at Site U1423, other than meeting minimum requirements, was to generate profiles of solids, gases, and interstitial waters that could constrain fluxes of reactants and products resulting from microbial decomposition of organic matter. With this goal, comparisons to profiles at Sites U1422 and U1424 might provide insight to interactions between the "deep biosphere" and overlying waters of the sea. We endeavored to 
construct a set of detailed records, although this was difficult given the limited time during operations at the site ( 2.9 days) and the transit $(\sim 6 \mathrm{~h})$ to the next site (U1424). In particular, while drilling at Site U1423 cores arrived on deck every 25-45 min, which left minimal time for analyses.

\section{Sample summary}

The geochemistry group collected and analyzed a range of samples. These included the following (Tables T10, T11, T12):

- 1 mudline (ML) water sample from inside the core liner above sediment of Core 346-U1423A-1H. We collected $50 \mathrm{~mL}$.

- 50 interstitial water samples from whole-round squeezing (IW-Sq) from Hole U1423A (44 samples) and the lower cores of Hole U1423B (6 samples) at nominal $4.5 \mathrm{~m}$ spacing. For most samples, we collected between 35 and $45 \mathrm{~mL}$ of interstitial water.

- 0 interstitial water samples from Rhizons.

- 41 sediment samples from the interstitial water squeeze cakes of Holes U1423A (35 samples) and U1423B (6 samples). All interstitial water squeeze cake samples from lithologic Unit I were analyzed, whereas alternate interstitial water squeeze cake samples from lithologic Unit II were analyzed.

- 50 headspace (HS) gas samples. All of these samples were "paired" with the IW-Sq samples.

- No gas samples on voids (Vacutainer) were taken because no large gas voids occurred during core recovery at Site U1423.

\section{Carbonate and organic carbon}

Sediment recovered at Site U1423 had only minor amounts of $\mathrm{CaCO}_{3}(\sim 0.4 \mathrm{wt} \%)$ (Fig. F22). In general, $\mathrm{CaCO}_{3}$ contents decrease from $\sim 1 \mathrm{wt} \%$ at $1.4 \mathrm{~m}$ CSF-A to $0.2 \mathrm{wt} \%$ at $18 \mathrm{~m}$ CSF-A and remain relatively low further downcore. The exceptions are samples centered around 56.3 and $70.3 \mathrm{~m} \mathrm{CSF-A,} \mathrm{which} \mathrm{have}$ slightly elevated $\mathrm{CaCO}_{3}$ (Table T10), and one sample at $41.8 \mathrm{~m}$ CSF-A with a $\mathrm{CaCO}_{3}$ content of $14.3 \mathrm{wt} \%$. This sample coincides with a zone rich in foraminifers (see "Biostratigraphy").

Total carbon content of sediment is primarily controlled by the total organic carbon (TOC) content, which has variable and high values in lithologic Subunit IA (Fig. F22). In the uppermost $20 \mathrm{~m}$ below seafloor, TOC ranges from $2.1 \mathrm{wt} \%$ in the uppermost sample at $1.45 \mathrm{~m}$ CSF-A to $0.2 \mathrm{wt} \%$ at $8.8 \mathrm{~m}$ CSF-A. The variability partly reflects the nature of discrete sampling of shallow sediment in the marginal sea. Sediment sequences in this region, particularly lithologic Subunit IA, have numerous centimeter-scale dark and light layers containing different amounts and compositions of organic matter (Föllmi et al., 1992; Tada et al., 1992). Our samples, which come from intervals squeezed for interstitial water, represent short thicknesses (originally $\sim 5 \mathrm{~cm}$ ) separated nominally by $4.5 \mathrm{~m}$. In any case, similar TOC variability has been observed in shallow sediment at other drill sites of the Japan Basin (Tamaki, Pisciotto, Allan, et al., 1990). Samples from lithologic Subunit IB, between $\sim 83$ and 103 m CSF-A, generally have lower TOC contents than those of lithologic Subunit IA. Interestingly, the highest TOC levels of Subunit IB are found near the base of the unit. Deeper than 103 m CSF-A and within lithologic Unit II, TOC contents are low, averaging $0.54 \mathrm{wt} \%$.

The mean value of total nitrogen (TN) is $0.2 \mathrm{wt} \%$. The maximum $\mathrm{TN}$ content $(0.3 \mathrm{wt} \%)$ is found at $\sim 30$ m CSF-A.

\section{Manganese and iron}

The dissolved Mn profile (Fig. F23) exhibits a fairly smooth trend with depth. Close to the seafloor, Mn concentration is below detection limit (determined to be $0.5 \mu \mathrm{M}$ ). However, by $1.5 \mathrm{~m}$ CSF-A, dissolved Mn concentrations spike to $120 \mu \mathrm{M}$ (Table T11). Beneath this depth, Mn concentrations decrease. The decrease is concave downward and decreases below detection limit at $\sim 37 \mathrm{~m}$ CSF-A. At $\sim 70 \mathrm{~m}$ CSF-A, dissolved Mn begins to increase again, reaching $\sim 25 \mu \mathrm{M}$ at $\sim 175$ m CSF-A.

The initial rise in dissolved Mn likely indicates a zone where microbes utilize Mn oxides and hydroxides to consume organic carbon (Froelich et al., 1979; Masuzawa and Kitano, 1983). Although our profile suggests dissolved $\mathrm{Mn}$ decreases to zero at the seafloor, the depth of zero dissolved Mn may lie somewhere between the seafloor and the uppermost sample at 1.5 m CSF-A (Masuzawa and Kitano, 1983). Our samples lack sufficient depth resolution to document a possible change in the slope of dissolved $\mathrm{Mn}$ concentration at shallow sediment depth. The second and deeper low in dissolved $\mathrm{Mn}$, from $\sim 37$ to 70 $\mathrm{m}$ CSF-A, suggests a horizon where a mineral removes $\mathrm{Mn}$ and then redissolves. This zone corresponds to the alkalinity maximum (Fig. F24). It is possible that dissolved $\mathrm{Mn}^{2+}$ released at shallow depth diffuses downhole to a zone of high $\mathrm{HCO}_{3}{ }^{-}$ concentration to form rhodochrosite $\left(\mathrm{MnCO}_{3}\right)$. In turn, with burial, the rhodochrosite may recrystallize as a different carbonate mineral, such as siderite, releasing dissolved $\mathrm{Mn}^{2+}$ at depth. Such an interpretation is consistent with theory (Middelburg et al., 1987), and previous studies provide evidence for this process in this marginal sea, in particular at ODP Site 
799 (Masuzawa and Kitano, 1983; Matsumoto, 1992). However, a thorough study comparing interstitial water and solid phases is required to confirm this interpretation.

The Fe profile at Site U1423 (Fig. F23) exhibits a high degree of variance, which may indicate the complexity of Fe cycling within the sediment, the challenges of measuring Fe, or both. Unlike Mn, Fe can be a major element in multiple authigenic minerals, including sulfides, phosphates, carbonates, and clay (Berner, 1981). Thus, the "bumpy" profile, where variations in dissolved Fe occur over short depth intervals, may reflect intervals where Fe is removed or liberated from different mineral phases. However, Fe also readily precipitates from water when exposed to oxygen. It is possible that when whole-round interstitial water samples are separated and squeezed, exposure to atmospheric oxygen causes precipitation of variable amounts of dissolved Fe. Furthermore, Fe concentrations may be near the detection limit of the instrument, which is quantified to be $0.9 \mu \mathrm{M}$ for this site.

Smooth interstitial water Fe profiles have been obtained using Rhizon samples at certain locations (e.g., the Arctic Ocean [Backman, Moran, McInroy, Mayer, and the Expedition 302 Scientists, 2006]). Moreover, the Rhizons can be inserted over very short depth increments in the event that dissolved Fe concentrations truly change over a short vertical distance. It would be intriguing to examine Fe concentrations using Rhizons across short depth intervals. No Rhizon sampling was done at this site, however.

\section{Alkalinity, ammonium, and phosphate}

The alkalinity, $\mathrm{NH}_{4}{ }^{+}$, and $\mathrm{PO}_{4}{ }^{3-}$ profiles at Site U1423 (Fig. F24) are similar to those at Site U1422 (see Fig. F25 in the "Site U1422" chapter [Tada et al., 2015c]) with two notable differences. First, the prominent inflection in alkalinity observed at Site U1422 is not found at Site U1423. Second, through the upper $50 \mathrm{~m}$ below the seafloor, concentrations of $\mathrm{NH}_{4}{ }^{+}$and $\mathrm{PO}_{4}{ }^{3-}$ are slightly greater at Site U1423 than at Site U1422.

Alkalinity increases from $2.4 \mathrm{mM}$ at the seafloor to $28 \mathrm{mM}$ at $51 \mathrm{~m}$ CSF-A. Below this depth, alkalinity decreases steadily to $15 \mathrm{mM}$ at $244 \mathrm{~m}$ CSF-A. The profile is concave downward to $50 \mathrm{~m} \mathrm{CSF-A}$ and slightly concave downward deeper than $50 \mathrm{~m}$ CSF-A. The lack of a shallow alkalinity inflection at Site U1423 suggests that a prominent sulfate-methane transition (SMT) does not exist at this location, al- though a change in slope can be observed at $27 \mathrm{~m}$ CSF-A.

Ammonium increases from $93 \mu \mathrm{M}$ near the seafloor to $2352 \mu \mathrm{M}$ at $56 \mathrm{~m}$ CSF-A. Below this depth, $\mathrm{NH}_{4}{ }^{+}$ drops steadily to $\sim 1776 \mu \mathrm{M}$ at $244 \mathrm{~m}$ CSF-A. The profile is concave downward until $50 \mathrm{~m}$ CSF-A but fairly linear below 50 m CSF-A.

Phosphate increases from $1.4 \mu \mathrm{M}$ at the seafloor to $106 \mu \mathrm{M}$ at $23 \mathrm{~m}$ CSF-A. Below this depth, $\mathrm{PO}_{4}{ }^{3-}$ decreases steadily to $<10 \mu \mathrm{M}$ at $136 \mathrm{~m}$ CSF-A. This decrease in $\mathrm{PO}_{4}{ }^{3-}$ has a concave downward profile.

Somewhat similar to Site U1422, the magnitude and overall shape of the profiles relate to microbial diagenesis of organic matter and authigenic mineral precipitation. Organic matter landing on the seafloor has a nominal C:N:P ratio of 106:16:1 (Froelich et al., 1979). During sediment burial, Bacteria and Archaea consume the organic matter through a suite of microbial reactions, which release $\mathrm{HCO}_{3}{ }^{-}, \mathrm{NH}_{4}{ }^{+}$, and $\mathrm{PO}_{4}{ }^{3-}$ to interstitial water. Dissolution of metal oxides also releases dissolved $\mathrm{PO}_{4}{ }^{3-}$ to shallow sediment (Cha et al., 2005). At great depth, $\mathrm{HCO}_{3}{ }^{-}$and $\mathrm{PO}_{4}{ }^{3-}$ precipitate into or onto mineral phases (Berner, 1981).

The higher $\mathrm{NH}_{4}{ }^{+}$and $\mathrm{PO}_{4}{ }^{3-}$ concentrations in the upper $50 \mathrm{~m}$ at Site U1423 compared to those at Site U1422 suggest greater input of organic carbon from at least the last few million years. However, $\mathrm{NH}_{4}{ }^{+}$and $\mathrm{PO}_{4}{ }^{3-}$ concentrations throughout deeper depths are higher overall at Site U1422 than at Site U1423, indicating a relatively higher organic carbon input at Site U1422 on a longer timescale. One possibility is that at Site U1423, although the products of organic decomposition occur in higher concentrations in Holocene and Late Pleistocene sediment, present lower concentrations than at Site U1422 when integrated over a longer time interval. These differences may be explained by a time of slow sedimentation (see "Stratigraphic correlation and sedimentation rates"), when organic inputs accumulated more slowly or when the $\mathrm{HCO}_{3}{ }^{-}, \mathrm{NH}_{4}{ }^{+}$, and $\mathrm{PO}_{4}{ }^{3-}$ products were lost through diffusion or mineral precipitation.

Interestingly, the $\mathrm{NH}_{4}{ }^{+}$concentration gradient at Site U1423 (as well as Site U1422 and other locations; see "Geochemistry" in the "Site U1422" chapter [Expedition 356 scientists, 2015c]) implies a modest upward flux of nitrogen from the interstitial water to the bottom water. Given the previous section and discussion about the $\mathrm{Mn}$ profile, we wonder whether $\mathrm{NH}_{4}{ }^{+}$concentration decreases to zero at the seafloor 
or, alternatively, at some sedimentary horizon below the seafloor.

\section{Volatile hydrocarbons}

Methane is the only hydrocarbon gas in all HS samples at Site U1423. No ethane or heavier hydrocarbons were detected.

In general, $\mathrm{CH}_{4}$ concentrations at Site U1423 (Fig. F25) are much lower than those at Site U1422. Concentrations are nearly zero over the upper $30 \mathrm{~m}$ CSF-A. Methane values increase downhole, reaching a peak of 2006 ppmv at $70 \mathrm{~m}$ CSF-A. The $\mathrm{CH}_{4}$ peak is prominent, but recall that saturation values of 10,000 ppmv were regularly measured at Site U1422 (see "Geochemistry" in the "Site U1422" chapter [Tada et al., 2015c]). Below $70 \mathrm{~m}$ CSF-A, $\mathrm{CH}_{4}$ concentrations decrease rapidly to below 10 ppmv at $155 \mathrm{~m}$ CSF-A and remain so to the bottom of Hole U1423B.

Degradation of organic matter produces modest amounts of $\mathrm{CH}_{4}$ between 30 and $130 \mathrm{~m} \mathrm{CSF-A.} \mathrm{Pro-}$ duction is probably greatest at $\sim 70 \mathrm{~m}$ CSF-A, where peak $\mathrm{CH}_{4}$ concentration occurs and dissolved alkalinity and $\mathrm{NH}_{4}{ }^{+}$concentrations are highest. Because of the relatively low concentrations, no major gas voids were observed at Site U1423.

A downhole comparison of $\mathrm{CH}_{4}$ and $\mathrm{SO}_{4}{ }^{2-}$ concentrations (Fig. F26) shows that an SMT occurs at Site U1423. However, this SMT is diffuse, occurring over 20 m between 30 and 50 m CSF-A.

\section{Sulfate and barium}

Profiles of dissolved $\mathrm{SO}_{4}{ }^{2-}$ and dissolved $\mathrm{Ba}$ at Site U1423 (Fig. F27) are somewhat similar to those at Site U1422. The major difference is the shape of the $\mathrm{SO}_{4}{ }^{2-}$ profile.

Dissolved $\mathrm{SO}_{4}{ }^{2-}$ concentration in the mudline sample is $28.6 \mathrm{mM}$, which compares favorably with an inferred $28.5 \mathrm{mM}$ in JSPW (see "Geochemistry" in the "Methods" chapter [Tada et al., 2015b]). From the seafloor to $\sim 50 \mathrm{~m}$ CSF-A, values steadily decrease. This decrease in $\mathrm{SO}_{4}{ }^{2-}$ exhibits a concave downward profile, in contrast to the more linear profile at Site U1422 (Fig. F27). Deeper than $\sim 50 \mathrm{~m} \mathrm{CSF-A,} \mathrm{SO}_{4}{ }^{2-}$ concentrations are consistently $<0.7 \mathrm{mM}$.

Dissolved Ba concentrations are $<30 \mu \mathrm{M}$ until $\sim 27 \mathrm{~m}$ CSF-A when values steadily rise. The highest Ba standard included in the inductively coupled plasmaatomic emission spectroscopy (ICP-AES) calibration curve was $364 \mu \mathrm{M}$, and this value is exceeded at 41.75 m CSF-A. Ba concentrations of each sample below this depth exceed this highest standard and are thus unconstrained. Therefore, any Ba values greater than $364 \mathrm{uM}$ are untrustworthy and $\mathrm{Ba}$ is thus reported here as "preliminary."

In contrast to Site U1422, the upward flux of $\mathrm{CH}_{4}$ and anaerobic oxidation of methane (AOM) play a minor role at Site U1423. Instead, the dominant net sink of $\mathrm{SO}_{4}{ }^{2-}$ below the seafloor is through microbial decomposition of solid organic carbon. This alternative pathway for sulfate reduction can be expressed in simplified form as follows (Berner, 1980):

$$
2 \mathrm{CH}_{2} \mathrm{O}+\mathrm{SO}_{4}{ }^{2-} \rightarrow \mathrm{HS}^{-}+2 \mathrm{HCO}_{3}^{-}+\mathrm{H}^{+} .
$$

Because this reaction dominates $\mathrm{SO}_{4}{ }^{2-}$ consumption and occurs over a thick depth interval, the $\mathrm{SO}_{4}{ }^{2-}$ profile has significant curvature and the alkalinity profile lacks a prominent kink.

Site U1423 is interesting to studies of Ba cycling in deep-sea sediment. $\mathrm{Ba}$ is released into pore water from barite dissolution when $\mathrm{SO}_{4}{ }^{2-}$ concentrations approach zero. As $\mathrm{SO}_{4}{ }^{2-}$ is depleted at depth, methanogenesis becomes the primary process oxidizing organic material, and thus high barium concentrations commonly occur with high $\mathrm{CH}_{4}$ concentrations. Site U1423 indicates that high dissolved Ba concentrations can occur without high $\mathrm{CH}_{4}$ concentrations at depth, which is unusual. The lack of methane suggests that fluxes of organic material are relatively low.

\section{Calcium, magnesium, and strontium}

At the mudline, dissolved Ca concentration is 10.2 $\mathrm{mM}$, which compares closely to the $10.4 \mathrm{mM}$ inferred in JSPW (see "Geochemistry" in the "Methods" chapter [Tada et al., 2015b]). Calcium concentrations smoothly decrease to $\sim 4.6 \mathrm{mM}$ at $32 \mathrm{~m}$ CSF-A (Fig. F28). This is close to but shallower than the depth where alkalinity reaches a maximum $(\sim 51 \mathrm{~m}$ CSF-A). Deeper than 32 m CSF-A, Ca concentrations steadily rise, reaching $13 \mathrm{mM}$ at the base of Hole U1423B (244 m CSF-A).

Magnesium concentration in the mudline sample $(51.7 \mathrm{mM})$ is lower than that of inferred JSPW (53.3 $\mathrm{mM}$ ) (see "Geochemistry" in the "Methods" chapter [Tada et al., 2015b]). Below the seafloor, dissolved $\mathrm{Mg}$ concentrations steadily decrease to $40 \mathrm{mM}$ at $\sim 22$ $\mathrm{m}$ CSF-A. Deeper in the sediment column, Mg concentrations continue to decrease, reaching $23 \mathrm{mM}$ at the base of Hole U1423B.

The Sr profile at Site U1423 is much smoother than at Site U1422, presumably because of improved shipboard analytical techniques. Dissolved Sr concentration is $87 \mu \mathrm{M}$ at the seafloor, which compares to 92 $\mu \mathrm{M}$ inferred in JSPW (see "Geochemistry" in the "Methods" chapter [Tada et al., 2015b]). The shal- 
lowest interstitial water sample at $1.45 \mathrm{~m} \mathrm{CSF-A} \mathrm{has}$ a Sr concentration of $93 \mu \mathrm{M}$. At $\sim 27 \mathrm{~m}$ CSF-A, Sr concentrations begin to increase, reaching $172 \mu \mathrm{M}$ at $\sim 70 \mathrm{~m}$ CSF-A (Fig. F28). The initiation of the Sr rise, and by inference the release of Sr into interstitial water, occurs at approximately the same depth as the minimum in dissolved $\mathrm{Ca}$, the inflection in dissolved $\mathrm{Mg}$, and is $\sim 20 \mathrm{~m}$ shallower than the maximum in alkalinity. Below 75 m CSF-A, Sr concentrations continue to increase, but the rate of increase is more gradual. Dissolved $\mathrm{Sr}$ is $202 \mu \mathrm{M}$ at $244 \mathrm{~m}$ CSF-A.

As at Site U1422 (see "Geochemistry" in the "Site U1422" chapter [Tada et al., 2015b]), two primary processes impact the $\mathrm{Ca}, \mathrm{Mg}$, and $\mathrm{Sr}$ profiles at Site U1423. Between 20 and $40 \mathrm{~m}$ CSF-A, there appears to be a phase that consumes $\mathrm{Ca}$ and $\mathrm{Mg}$ while releasing Sr. It is likely that dolomite $\left[\mathrm{Ca}, \mathrm{Mg}\left(\mathrm{CO}_{3}\right)_{2}\right]$ is precipitating in this interval, perhaps concurrent with dissolution of $\mathrm{CaCO}_{3}$, which would add $\mathrm{Sr}$ to the interstitial water. The anomalous peak in $\mathrm{CaCO}_{3}$ concentrations in the sediment occurs at the bottom of this interval at $41 \mathrm{~m} \mathrm{CSF-A.} \mathrm{We} \mathrm{note} \mathrm{that} \mathrm{the} \mathrm{de-}$ crease in $\mathrm{Mg}$ concentrations $(14 \mathrm{mM})$ is much greater than that of Ca concentrations $(6 \mathrm{mM})$ over the upper $30 \mathrm{~m}$ (Fig. F28). Further discussion involving flux-based calculations of a dissolved species into and out of the horizon will aid this interpretation. Specifically, as evidenced by the diffusion gradients, dissolved $\mathrm{Ca}$ is also entering the "precipitation" horizon from depth, whereas dissolved $\mathrm{Mg}$ is leaving the precipitation horizon to depth. If one considers fluxes above and below the probable reaction interval, the consumption of $\mathrm{Ca}$ and $\mathrm{Mg}$ from interstitial water is much closer to $1: 1$, which is consistent with dolomite formation.

The other main process affecting the $\mathrm{Ca}, \mathrm{Mg}$, and $\mathrm{Sr}$ profiles at Site U1423 is basalt alteration, as was seen in many of the ODP Leg 127/128 interstitial water profiles (Murray et al., 1992). This general reaction consumes $\mathrm{Mg}$ and produces both $\mathrm{Ca}$ and $\mathrm{Sr}$ (Gieskes and Lawrence, 1981).

\section{Salinity, chlorinity, sodium, and pH}

Water beneath the thermocline in the marginal sea is often called JSPW. It has a practical salinity $(S)$ of $34.06 \pm 0.01$ (Sudo, 1986). Once calibrated to molarity, measured concentrations of conservative ions in the mudline sample have values similar to JSPW (Table T11). This includes $\mathrm{Cl}^{-}$and $\mathrm{Na}$. We measured concentrations of $541 \mathrm{mM}$ or $547 \mathrm{~mol} / \mathrm{kg}$ of seawater for $\mathrm{Cl}^{-}$and $468 \mathrm{mM}$ or $473 \mathrm{~mol} / \mathrm{kg}$ of seawater for $\mathrm{Na}$, which compare to $551 \mathrm{~mol} / \mathrm{kg}$ of seawater $\mathrm{Cl}^{-}$ and $473 \mathrm{~mol} / \mathrm{kg}$ of seawater $\mathrm{Na}$ for seawater with $S$ of 34.06 .
The depth profiles of salinity, $\mathrm{Cl}^{-}$, and $\mathrm{Na}$ each indicate a zone that is less saline than JSPW between the seafloor and $\sim 52 \mathrm{~m}$ CSF-A (Fig. F29). Although salinity, $\mathrm{Cl}^{-}$, and $\mathrm{Na}$ values are not measured precisely with standard shipboard instruments, they collectively suggest water with salinity $\sim 32$ in this depth interval. Interstitial water that is less saline than JSPW was also found in shallow sediment at sites drilled during Leg 127. At the time, the shipboard scientific party attributed the low-salinity waters to sulfate reduction (Tamaki, Pisciotto, Allan, et al., 1990). However, this does not seem a reasonable explanation because although sulfate reduction may decrease the total mass of dissolved ions in seawater, it would not decrease $\mathrm{Cl}^{-}$or Na concentrations.

There appear to be two general possibilities for the relatively low salinity water. First, and given the proximity of Site U1423 to land, groundwater could be extending from the coast in relatively permeable horizons beneath the seafloor. This occurs along many continental margins, as seen, for example, at ODP drill sites across the New Jersey margin (Malone et al., 2002; van Geldern et al., 2013). Second, this water represents the evolving remnant of interstitial water that was in diffusive exchange with bottom water of the sea that was fresher sometime in the recent past. Most of the world's deep ocean water was more saline during the Last Glacial Maximum (LGM) relative to present day. As such, interstitial water salinity usually increases over the uppermost $40-50 \mathrm{~m}$ below the seafloor (Schrag et al., 1996; Adkins et al., 2002). However, this marginal sea has a complicated late Quaternary history, in part because shallow sills restrict deepwater flow to and from the adjacent $\mathrm{Pa}$ cific Ocean (Oba et al., 1991). Low-salinity deep water during the LGM may explain the $\delta^{18} \mathrm{O}$-depleted benthic foraminifers found in sediments of this age in this marginal sea (Oba et al., 1991).

Irrespective of origin, the presence of lower salinity water in shallow sediment will enhance deviations in concentration profiles.

\section{Potassium}

$\mathrm{K}$ concentration (Fig. F29) is $\sim 10.1 \mathrm{mM}$ in the mudline sample, which compares to $10.3 \mathrm{mM}$ for inferred JSPW (see "Geochemistry" in the "Methods" chapter [Tada et al., 2015b]). After an increase to $\sim 11.6 \mathrm{mM}$ at $1.45 \mathrm{~m}$ CSF-A, concentrations remain high to deeper than 8.75 m CSF-A when K concentrations decrease steadily, reaching $7.4 \mathrm{mM}$ at $244 \mathrm{~m}$ CSF-A. An increase in K concentrations immediately below the seafloor was also found at Site U1422 and may reflect exchange during authigenic mineral formation. The decrease in $\mathrm{K}$ concentrations with depth perhaps results from further reactions with ash and 
basalt (Murray et al., 1992), although formation of glauconite would also remove $\mathrm{K}^{+}$from interstitial water (Föllmi and von Breymann, 1992).

It is noteworthy that $\mathrm{K}$ concentrations between 10 and $60 \mathrm{~m}$ CSF-A deviate from the general downhole trend to lower values. This deviation may result from the aforementioned freshening.

\section{Lithium and boron}

Li concentration (Fig. F30) is $22 \mu \mathrm{M}$ in the mudline sample. Li values decrease to as low as $15 \mu \mathrm{M}$ at $13 \mathrm{~m}$ CSF-A. Below this depth, Li concentrations increase to $110 \mu \mathrm{M}$ at $244 \mathrm{~m}$ CSF-A.

B concentration (Fig. F30) is $412 \mu \mathrm{M}$ at the mudline, which is approximately that of JSPW. Values increase to $>1072 \mu \mathrm{M}$ at the bottom of Site U1423 (244 m CSF-A). The profile is very similar to that presented for ODP Site 795 (Brumsack and Zuleger, 1992). They suggested multiple possible explanations for the downhole variations in $\mathrm{B}$. We note that below $25 \mathrm{~m}$ CSF-A, B concentrations increase more rapidly than at shallower depths, suggesting that deep microbial reactions may somehow affect $B$ concentrations in interstitial water.

\section{Silica}

Silica concentrations in interstitial water at Site U1423 (Fig. F30) increase from initial values of 98 $\mu \mathrm{M}$ in the bottom water ( $0 \mathrm{~m}$ CSF-A) to $\sim 1550 \mu \mathrm{M}$ at $244 \mathrm{~m}$ CSF-A. The opal-A/opal-CT boundary was not drilled at Site U1423, so the expected decrease in dissolved $\mathrm{H}_{4} \mathrm{SiO}_{4}$ at depth (Tamaki, Pisciotto, Allan, et al., 1990) was not observed.

The profile of $\mathrm{Si}$ measured using ICP-AES and the profile of $\mathrm{H}_{4} \mathrm{SiO}_{4}$ measured using the spectrophotometer match fairly well.

\section{Preliminary conclusions}

The geochemistry at Site U1423 has similarities and differences to that at Sites 794 and 795, as well as Sites U1422 and U1424. At all these sites, modest amounts of organic carbon land on the seafloor. Microbes then utilize this organic material to drive a series of reactions that conform to an established sequence (Froelich et al., 1979). The sum of the reactions releases $\mathrm{HCO}_{3}{ }^{-}, \mathrm{PO}_{4}{ }^{3-}$, and $\mathrm{NH}_{4}{ }^{+}$to interstitial water, whereas component reactions affect concentrations of select dissolved constituents. For example, metal oxide reduction releases $\mathrm{Mn}$ and Fe to interstitial water and sulfate reduction removes $\mathrm{SO}_{4}{ }^{2-}$ from interstitial water. The changing interstitial water composition also leads to mineral dissolution and precipitation.
Superimposed on this organic diagenesis framework are three other processes that impact all sites in the region. Two of these processes-alteration of basalt and recrystallization of biogenic silica-occur deeper than 300 m CSF-A but still affect water composition throughout the sediment column. The other apparently important process is changing chemistry at the seafloor, specifically the presence of lower salinity deep water in the recent past.

The primary difference between the sites is the degree of organic diagenesis, at least over long time frames. For example, $\mathrm{CH}_{4}$ levels at Site U1422 are at least 16 times higher than those at Site U1423, and this leads to a prominent SMT and significant AOM at the first location. Potentially, different types of organic matter could cause major variations in alkalinity, $\mathrm{NH}_{4}{ }^{+}, \mathrm{PO}_{4}{ }^{3-}, \mathrm{SO}_{4}{ }^{2-}$, and $\mathrm{CH}_{4}$ concentrations, as they are all involved in organic matter degradation. More likely though, differential supply of similar organic matter over time causes the variations at the sites.

\section{Paleomagnetism}

\section{Paleomagnetic samples and measurements}

Paleomagnetic investigations for cores collected at Site U1423 included the measurement of magnetic susceptibility of whole-core and archive-half splitcore sections and of natural remanent magnetization (NRM) of archive-half sections. NRM was measured before and after alternating field (AF) demagnetization with a $20 \mathrm{mT}$ peak field for all archive-half sections from Hole U1423A. Because of increased speed of core flow, NRM of archive-half sections from Holes U1423B and U1423C was measured only after $20 \mathrm{mT}$ AF demagnetization at every $5 \mathrm{~cm}$ interval. The FlexIT core orientation tool (see "Paleomagnetism" in the "Methods" chapter [Tada et al., 2015b]) was used to orient 20 APC cores in Hole U1423A, starting from Core 346-U1423A-2H. Core orientation data collected in Hole U1423A are reported in Table T13.

We typically collected one paleomagnetic discrete cube sample (see "Paleomagnetism" in the "Methods" chapter [Tada et al., 2015b]) from the first section of each core in Hole U1423A, and occasionally from deep sections when the first section was not suitable for collecting a discrete cube sample. Four discrete samples were collected at deep depths from the bottom four cores in Hole U1423B, and two additional discrete samples were collected from Hole U1423C. Depth levels where the discrete samples were taken are marked by triangles along the left side of the paleomagnetic inclination data column in Fig- 
ure F31. Stepwise AF demagnetization on 12 discrete samples from Hole U1423A, 1 discrete sample from Hole U1423B, and 2 discrete samples from Hole U1423C was performed at successive peak fields of 0 , $5,10,15,20,25,30,35,40,45,50,55$, and $60 \mathrm{mT}$ to verify the reliability of the split-core measurements and to determine the demagnetization behavior of the recovered sediment. Following each demagnetization step, NRM of the discrete samples was measured with the sample placed in the "top-toward" or "+Z-axis toward magnetometer" orientation (see "Paleomagnetism" in the "Methods" chapter [Tada et al., 2015b]) on the discrete sample tray.

We processed data extracted from the shipboard Laboratory Information Management System (LIMS) database by removing all measurements collected from disturbed and void intervals and all measurements that were made within $10 \mathrm{~cm}$ of the section ends, which are slightly biased by measurement edge effects. A modified version of the UPmag software (Xuan and Channell, 2009) was used to analyze the NRM data of both the split-core section and the discrete cube samples. The disturbed and void intervals used in this process are reported in Table T14. The processed NRM inclination, declination, and intensity data after $20 \mathrm{mT}$ AF demagnetization are reported in Table T15 and shown in Figure F31.

\section{Natural remanent magnetization and magnetic susceptibility}

The intensity of NRM after $20 \mathrm{mT}$ AF demagnetization in all three holes is similar in magnitude for overlapping intervals, mostly ranging from $\sim 10^{-5}$ to $10^{-2} \mathrm{~A} / \mathrm{m}$. For core sections from the uppermost $\sim 25 \mathrm{~m}, \mathrm{NRM}$ intensity is on the order of $10^{-2} \mathrm{~A} / \mathrm{m}$. NRM intensity drops downcore to the order of $10^{-4}$ to $10^{-3} \mathrm{~A} / \mathrm{m}$ between $\sim 25$ and $\sim 50 \mathrm{~m} \mathrm{CSF-A}$. Deeper than $\sim 50 \mathrm{~m}$ CSF-A until the bottom of the holes, NRM intensities are mostly on the order of $\sim 10^{-4} \mathrm{~A} / \mathrm{m}$.

The AF demagnetization behavior of eight discrete samples from normal and reversed polarity intervals at varying depths is illustrated in Figure F32. Declination and inclination values acquired from the discrete sample measurement generally agree well with the split-core measurement after $20 \mathrm{mT}$ AF demagnetization. All samples exhibit a steep, normal overprint that was generally removed after AF demagnetization at peak fields of $\sim 10-15 \mathrm{mT}$, demonstrating that the $20 \mathrm{mT} \mathrm{AF}$ demagnetization is, in general, sufficient to eliminate the overprint. For measured discrete samples from deeper than $\sim 50 \mathrm{~m}$ CSF-A, NRM intensities before and after stepwise demagnetizations are generally one magnitude lower than those from shallower than this level. NRM measure- ment of discrete samples from the deep depth with weak intensity values often appears to be significantly affected by an anhysteretic remanent magnetization, possibly acquired because of bias caused by ambient magnetic field during AF demagnetization.

Magnetic susceptibility measurements were taken on whole cores from all three holes as part of the Whole-Round Multisensor Logger (WRMSL) analysis and on archive-half split-core sections using the Section Half Multisensor Logger (SHMSL) (see "Physical properties"). The WRMSL-acquired susceptibility was stored in the database in raw meter units. These were multiplied by a factor of $0.68 \times 10^{-5}$ to convert to the dimensionless volume SI unit (Blum, 1997). A factor of $(67 / 80) \times 10^{-5}$ was multiplied by the SHMSL-acquired susceptibility stored in the database. Magnetic susceptibility varies between $10 \times 10^{-5}$ and $90 \times 10^{-5} \mathrm{SI}$ for sediment from the uppermost $\sim 25 \mathrm{~m}$ of the holes and is generally $<10 \times 10^{-5} \mathrm{SI}$ for sediment from below $\sim 25 \mathrm{~m}$ CSF-A (Fig. F31, fourth panel). Magnetic susceptibility measurements are consistent between the two instruments and, in general, mimic NRM intensity, suggesting that the magnetic minerals that carry NRM are the same or at least coexist with those that dominate magnetic susceptibility.

\section{Magnetostratigraphy}

In spite of the drill string overprint and generally low NRM intensity, paleomagnetic inclination and declination data of the holes appear to show patterns that allow for the determination of magnetic polarity for the uppermost $\sim 110 \mathrm{~m}$ of recovered sediment in Holes U1423A and U1423B. Both paleomagnetic declination and inclination after $20 \mathrm{mT}$ AF demagnetization were used when possible for magnetostratigraphic interpretation at Site U1423. The geomagnetic field at the latitude of Site U1423 $\left(41.6992^{\circ} \mathrm{N}\right)$ has an expected inclination of $\sim 60.7^{\circ}$, assuming a geocentric axial dipole field model, which is sufficiently steep to determine magnetic polarity in APC cores that lack horizontal orientation. We identified the Brunhes/Matuyama boundary (0.781 Ma), the Jaramillo (0.988-1.072 Ma) and Olduvai (1.778-1.945 Ma) Subchrons, and the Matuyama/Gauss boundary (2.581 Ma) at Site U1423 (Table T16).

The Brunhes/Matuyama boundary is recorded at $\sim 52.5 \mathrm{~m}$ CSF-A in Hole U1423A and at $\sim 51.7 \mathrm{~m}$ CSF-A in Hole U1423B. Shallower than this boundary, inclination values after $20 \mathrm{mT}$ AF demagnetization vary around the expected dipole inclination value of $\sim 60.7^{\circ}$. Just deeper than this boundary, inclination is dominated by shallow and negative values. The two 
discrete samples from 17.69 and 46.27 m CSF-A measured with stepwise AF demagnetization show stable and positive inclinations around the expected dipole value of $\sim 60^{\circ}$ (Fig. F32A, F32B). In Hole U1423A around this boundary, the FlexIT-corrected declination appears to change from values close to $0^{\circ}$ to values mostly $\sim 180^{\circ}$. The depth of the Brunhes/Matuyama boundary is consistent with the appearance of a tephra layer at $\sim 45 \mathrm{~m}$ CSF-A, recognized as the "Hkd-ku," and with a known age of $\sim 0.78 \mathrm{Ma}$ (see "Lithostratigraphy").

Between $\sim 57.3$ and $\sim 61.2 \mathrm{~m}$ CSF-A in Hole U1423A, FlexIT-corrected declination shows values mainly around $0^{\circ}$, and inclination appears to be dominated by the expected normal polarity dipole value of the site. We interpret this $\sim 4 \mathrm{~m}$ interval as the Jaramillo Subchron (C1r.1n, 0.988-1.072 Ma). In Hole U1423B, the Jaramillo Subchron is recognized between $\sim 58.4$ and $\sim 62.3 \mathrm{~m}$ CSF-A with inclination varying mostly around the expected normal polarity dipole value (Fig. F31B).

Between $~ 76.4$ and $~ 94.5 \mathrm{~m}$ CSF-A in Hole U1423A, the FlexIT-corrected declination values clearly vary around $0^{\circ}$, with inclination values dominated by the expected normal polarity dipole value. We interpret this interval as the Olduvai Subchron (C2n, 1.778$1.945 \mathrm{Ma}$ ). The declination of Core 346-U1423B-9H, although not oriented, shows an $\sim 180^{\circ}$ shift at $\sim 76$ $\mathrm{m}$ CSF-A, whereas inclination appears to change from shallow and negative values to mostly positive dipole values. This depth level is recognized as the top of the Olduvai Subchron recorded in Hole U1423B. The bottom of the Olduvai Subchron is not clearly recorded in Hole U1423B. The depth levels of the Olduvai Subchron in the holes are consistent with the LO of Axoprunum acquilonium (1.2-1.7 Ma) at 74.14-93.17 m CSF-A in Hole U1423A (see "Biostratigraphy").

At $\sim 112$ m CSF-A in Hole U1423A and 113.6 m CSF-A in Hole U1423B, inclination after $20 \mathrm{mT}$ AF demagnetization in both holes appears to change from shallow and negative values to dominant steep positive values. In Hole U1423A just deeper than this level, FlexIT-corrected declinations vary around $0^{\circ}$. We tend to interpret this level as the Matuyama/ Gauss boundary $(2.581 \mathrm{Ma})$. This interpretation agrees with the FO of Cycladophora davisiana (2.7 Ma) at $112.06-121.7 \mathrm{~m}$ CSF-A in Hole U1423A. Deeper than $140 \mathrm{~m}$ CSF-A in Holes U1423A and U1423B, inclination and declination both show large scatter, and it is difficult to make any reliable magnetostratigraphic interpretations. For the six measured APC cores recovered from Hole U1423C, inclination after $20 \mathrm{mT}$ AF demagnetization shows mostly positive values that are apparently steeper than the expected dipole value. The lack of orientation and significant changes in paleomagnetic directions make it difficult for magnetostratigraphic interpretations for Hole U1423C.

\section{Physical properties}

Physical properties measurements at Site U1423 were conducted to provide high-resolution data on the bulk physical properties and their downhole variations in Holes U1423A and U1423B. High-resolution scanning at $2.5 \mathrm{~cm}$ intervals on whole-round sections was immediately performed with both the WRMSL (Sections 1, 2, and 3) and Special Task Multisensor Logger (STMSL) (Sections 4, 5, 6, and 7) after the cores were sectioned on the catwalk. The WRMSL was used to measure gamma ray attenuation (GRA) bulk density, magnetic susceptibility, and $P$ wave velocity, whereas the STMSL measured GRA bulk density and magnetic susceptibility. The GRA bulk density and magnetic susceptibility from each section were combined into individual core data sets for stratigraphic correlation. $P$-wave velocities measured in Sections 1, 2, and 3 with the WRMSL were consolidated into individual core data sets as well.

After the sections reached thermal equilibrium with the ambient room temperature of $\sim 20^{\circ} \mathrm{C}$, thermal conductivity (one per core) and NGR measurements (eight per full section) completed the suite of wholecore measurements. Cores were then split parallel to the core axis. One half was reserved for archiving and one half was for analysis and sampling (working half). Shear stress measurements (one per core) were performed on the working halves of Hole U1423A and the lower part of Hole U1423B (below $205 \mathrm{~m}$ CSF-A) with more success. Moisture and density measurements were performed on discrete core samples (two per core) collected from the working halves of Hole U1423A and the lower part of Hole U1423B. Spectral diffuse reflectance (mostly at $1 \mathrm{~cm}$ intervals) and point magnetic susceptibility (mostly at $2 \mathrm{~cm}$ intervals) were measured using the SHMSL on the archive halves. Physical properties measurements are presented in Figures F33, F34, F35, and F36.

\section{Thermal conductivity}

Thermal conductivity was measured once per core using the full-space probe, usually near the middle of Section 4 . Thermal conductivity values range from $\sim 0.8$ to $\sim 1.1 \mathrm{~W} /(\mathrm{m} \cdot \mathrm{K})$. Values are largely scattered from 0 to $120 \mathrm{~m}$ CSF-A and nearly constant at $\sim 0.9$ $\mathrm{W} /(\mathrm{m} \cdot \mathrm{K})$ deeper than $120 \mathrm{~m}$ CSF-A. This highly variable feature in lithologic Subunits IA, IB, and IIA and the lack of an increasing trend downhole suggest a compositional control on this parameter. 


\section{Moisture and density}

GRA wet bulk density was measured using the WRMSL and STMSL. Although measurement error exists in GRA bulk density data because of the presence of air between sediments and the core liner, in general, GRA bulk density tends to reflect the characteristic of each lithologic unit (Fig. F33; see "Lithostratigraphy"). Similar to Site U1422, GRA bulk density at Site U1423 is highly variable in the upper part (between 0 and $103 \mathrm{~m} \mathrm{CSF-A)} \mathrm{with} \mathrm{values} \mathrm{rang-}$ ing from 1.2 to $1.8 \mathrm{~g} / \mathrm{cm}^{3}$. High variations of GRA bulk density in this interval are closely related to the alternating very dark brown to black organic-rich sediment and lighter olive and green hemipelagic sediment. This relationship is matched well with the high GRA bulk density values characteristic of the dark layer-organic rich intervals in Site U1422. After sharply decreasing at $103 \mathrm{~m}$ CSF-A, coinciding with the lithologic Unit I/II boundary, GRA bulk density tends to decrease slightly with depth to 249 m CSF-A. GRA bulk density at Site U1423 correlates well with the density log acquired in open Hole U1423B (see Fig. F37 and "Downhole measurements").

Although discrete wet bulk density and grain density are relatively constant for the entire interval, ranging from 1.2 to $1.6 \mathrm{~g} / \mathrm{cm}^{3}$ and from 2.4 to $2.8 \mathrm{~g} / \mathrm{cm}^{3}$, respectively, the primary trends agree well with GRA bulk density (Fig. F35). Porosity and water content show generally reversed trends when compared to density, ranging from $68.1 \%$ to $84.7 \%$ and from $45.0 \%$ and $70.5 \%$, respectively. Discrete bulk density and grain density have small step increases between 0 and $20 \mathrm{~m}$ CSF-A, where porosity and water content of the sediment decrease inversely. The trend of increasing density downhole reverses at $\sim 20 \mathrm{~m}$ CSF-A and then generally decreases to the bottom of the hole. Porosity and water content gradually increase below $20 \mathrm{~m}$ CSF-A and vary highly with depth. However, all discrete bulk density, grain density, porosity, and water content measurements remain relatively constant from $103 \mathrm{~m}$ CSF-A to the bottom of the hole, corresponding to lithologic Unit II. The largest scatter of discrete bulk density and porosity occurs between 55 and $75 \mathrm{~m}$ CSF-A.

\section{Magnetic susceptibility}

Magnetic susceptibility is the degree to which a material can be magnetized by an external magnetic field. Therefore, magnetic susceptibility provides information about sediment composition. Magnetic susceptibility at Site U1423 generally decreases with depth (Fig. F33). Although the mean values remain between $10 \times 10^{-5}$ and $20 \times 10^{-5}$ SI for this site, the highest magnetic susceptibility readings occur shal- lower than $\sim 22 \mathrm{~m}$ CSF-A (average $=91.5 \times 10^{-5} \mathrm{SI}$ ) with high variation. A magnetic susceptibility maximum occurs between 20 and 22 m CSF-A, where values as high as $200 \times 10^{-5}$ SI were measured. This occurrence of high magnetic susceptibility in the uppermost part (as was also the case with Site U1422) is likely due to highly magnetic authigenic mineral formation because there is no apparent primary lithologic correspondence to this region (see "Lithostratigraphy"). This lack of correlation between magnetic susceptibility and decimeter-scale lithology also suggests a diagenetic influence is decreasing the signal between 0 and $22 \mathrm{~m}$ CSF-A near the SMT zone with the signal severely muted deeper. After a large step decrease of magnetic susceptibility between 22 and $25 \mathrm{~m}$ CSF-A, magnetic susceptibility tends to decrease slightly downhole, with the exception of spikes of low magnetic susceptibility from 110 to $123 \mathrm{~m}$ CSF-A. Magnetic susceptibility also shows a small decrease at $\sim 70 \mathrm{~m}$ CSF-A.

Point magnetic susceptibility from the SHMSL agrees with the whole-core trends as well (Fig. F33), but values become significantly greater with depth than the whole-core equivalents. The increasing gap between two magnetic susceptibility values in the lower part of the hole may be related to fractures in the wholecore sediment and the inherent smoothing imposed by the magnetic susceptibility loop, resulting in reduced the whole-core intensity.

\section{Natural gamma radiation}

The variation patterns of NGR are conformable with GRA bulk density and correlate well with the total gamma ray log acquired in open Hole U1423B (see Fig. F37 and "Downhole measurements"). Between 0 and $20 \mathrm{~m}$ CSF-A, the total NGR counts show a large step increase from 15 to $40 \mathrm{cps}$ and then slightly increase to $70 \mathrm{~m}$ CSF-A. Although the total NGR counts show strong cyclicity between 20 and $125 \mathrm{~m}$ CSF-A, the highest NGR counts (82 cps) occur at $\sim 70$ $\mathrm{m}$ CSF-A, corresponding to a maximum in GRA bulk density. NGR counts gradually decrease between 70 and $125 \mathrm{~m}$ CSF-A, which coincides with the lithologic Subunit IIA/IIB boundary and also approximates the depth at which the logging Subunit LIa/ LIb boundary has been placed (see Fig. F38). The sharp decrease from 40 to $17 \mathrm{cps}$ near $103 \mathrm{~m}$ CSF-A coincides with the Unit I/II boundary and the depth of decreasing GRA bulk density and magnetic susceptibility. As discussed at Site U1422, these variation patterns of NGR may be explained by increased $\mathrm{U}$ associated with organic-rich layers in Unit I. This interpretation is in agreement with the downhole spectral gamma ray measurements performed in Hole U1423B, evidencing a higher mean uranium 
content above $\sim 103$ mbsf compared to the rest of the hole (see Fig. F38). Subsequently, low NGR counts remain stable to $180 \mathrm{~m}$ CSF-A with relatively less scatter. NGR counts again slightly decrease between 180 and 200 CSF-A and then inversely increase to the bottom of the hole.

\section{Compressional wave velocity}

Compressional $P$-wave velocity was measured with the WRMSL in Sections 1, 2, and 3 of each core for Holes U1423A and U1423B. Although $P$-wave velocity is generally measured with the WRMSL after the sections reach thermal equilibrium with the ambient room temperature of $\sim 20^{\circ} \mathrm{C}$ because $P$-wave velocity is significantly affected by temperature (Shumway, 1958), $P$-wave velocity at Site U1423 was measured before temperature equilibrium $\left(\sim 12^{\circ} \mathrm{C}\right)$ for quick stratigraphic correlation. Therefore, we remeasured $P$-wave velocity after temperature equilibrium $\left(\sim 20^{\circ} \mathrm{C}\right)$ in Cores $346-\mathrm{U} 1423 \mathrm{~B}-3 \mathrm{H}, 7 \mathrm{H}$, and $16 \mathrm{H}$ to compare with $P$-wave velocity measured before temperature equilibrium $\left(\sim 12^{\circ} \mathrm{C}\right)$. The two sets of $P$-wave velocity values matched well (Fig. F34) with average maximum differences of $5 \mathrm{~m} / \mathrm{s}$ (i.e., Core $3 \mathrm{H}$ was $1509 \mathrm{~m} / \mathrm{s}$ before and $1514 \mathrm{~m} / \mathrm{s}$ after, Core $7 \mathrm{H}$ was $1517 \mathrm{~m} / \mathrm{s}$ before and $1519 \mathrm{~m} / \mathrm{s}$ after, and Core $16 \mathrm{H}$ was $1525 \mathrm{~m} / \mathrm{s}$ before and $1526 \mathrm{~m} / \mathrm{s}$ after). However, because of poor sediment-to-liner coupling or the influence of small cracks in the relatively stiff and brittle sediment, results from the WRMSL include significantly higher or lower values than a typical data set. These values were removed manually, and then the $P$-wave velocity was combined as one data set of values from each hole (Fig. F33).

$P$-wave velocity at Site U1423 varies from 1451 to $1570 \mathrm{~m} / \mathrm{s}$ (average $=1524 \mathrm{~m} / \mathrm{s}$ ) and generally increases with depth. Although $P$-wave velocity also shows relatively higher variation above $103 \mathrm{~m}$ CSF-A relative to the lower part, the trend is not clear enough to reflect the lithologic changes.

\section{Vane shear stress}

Undrained shear strength of soft sediment in the working half of the core was measured using an analog vane shear device. Shear strength ranges from 5.5 to $126 \mathrm{kPa}$ and generally increases with depth (Fig. F35). In spite of the small scatter in the values, the curve does not show general trends that can be divided into successive intervals, although shear strength values at some depths (e.g., $\sim 56$ and $\sim 189 \mathrm{~m}$ CSF-A) reflect well the composition of sediment. Although the stratigraphic distance between two measurements obtained from a black organic layer (56.45 $\mathrm{m}$ CSF-A) and a paired light green hemipelagic layer (56.55 m CSF-A) of Core 346-U1423A-7H is only 10 $\mathrm{cm}$, shear strength sharply increases from 39.6 to $50.1 \mathrm{kPa}$ in this interval. Shear strength abruptly decreases at 189 m CSF-A, where a highly diatomaceous layer occurs. The high fluid content in the diatomaceous layer at this depth is likely responsible for this decrease in shear strength.

\section{Diffuse reflectance spectroscopy}

Color reflectance data measured on the split archivehalf sections show high variation of color, especially between 0 and $100 \mathrm{~m}$ CSF-A (Fig. F36). The $\mathrm{L}^{*}, \mathrm{a}^{*}$, and $b^{*}$ values represent lightness, red-green ratio, and yellow-blue ratio, respectively. These variations in color reflectance are closely related to lithologic changes. For example, the lithologic characteristic of Unit I, which consists of alternating very dark brown to black organic-rich sediment and lighter olive and green hemipelagic sediment, is responsible for the high variation of color reflectance. As was the case at Site U1422, as the dark bands fade out downhole in Unit II the color reflectance of $\mathrm{L}^{*}$ and $\mathrm{a}^{*}$ shows little variation to the bottom of the hole.

\section{Summary}

Physical properties measured at Site U1423 generally show trends that follow lithostratigraphy. Magnetic susceptibility, bulk density, and NGR have higher values in lithologic Unit I than in Unit II, whereas porosity and water content show opposite trends. $P$ wave velocity and shear strength gradually increase with depth because of sediment compaction. Color reflectance shows higher variation in lithologic Unit I than in Unit II, and the variations are closely related to the lithology of Unit I, which consists of alternating very dark brown to black organic-rich bands and lighter olive to green hemipelagic sediment.

\section{Downhole measurements}

\section{Logging operations}

Downhole logging measurements in Hole U1423B were made after completion of APC coring to a total depth of $249.1 \mathrm{~m}$ CSF-A. In preparation for logging, the hole was circulated and the pipe was pulled up to $80 \mathrm{~m}$ CSF-A. Two tool strings were deployed in Hole U1423B: the paleo combo and FMS-sonic (Fig. F39) (see "Downhole measurements" in the "Methods" chapter [Tada et al., 2015b]; for tool acronyms see Table T12 in the "Methods" chapter [Tada et al., 2015b]).

On 22 August 2013 at 0915 h UTC, the paleo combo tool string (comprising resistivity, density, NGR, and magnetic susceptibility tools) descended from the rig 
floor into the pipe. A downlog was taken at $\sim 600 \mathrm{~m} / \mathrm{h}$ and reached the base of the hole at $\sim 251 \mathrm{~m}$ WSF (see "Downhole measurements" in the "Methods" chapter [Tada et al., 2015b]). The hole was logged up (Pass 1 ) to $\sim 121 \mathrm{~m} \mathrm{WSF}$ at $540 \mathrm{~m} / \mathrm{h}$. The tool string returned for a second pass (main pass) from the bottom of the hole to the seafloor.

The FMS-sonic was rigged at $\sim 1200 \mathrm{~h}$ on 22 August. A downlog was taken at $850 \mathrm{~m} / \mathrm{h}$, from which we established the best settings for the source frequency and the automated picking of $P$-wave velocity from the sonic waveforms. The tool string reached the base of the hole at $250.7 \mathrm{~m}$ WSF. Two uphole passes of the FMS-sonic were run, Pass 1 to $\sim 120 \mathrm{~m} \mathrm{WSF}$ and Pass 2 to the seafloor, both at $550 \mathrm{~m} / \mathrm{h}$. Rig down was completed at $1855 \mathrm{~h}$.

The seafloor depth was given by the step in the gamma logs. There is typically some variability in choosing the exact point because the seafloor can appear as a gradual change. The paleo combo down$\log$ found the seafloor at $1794.5 \mathrm{~m} \mathrm{WRF}$ and the up$\log$ (Pass 2) found it at $1793.5 \mathrm{~m}$ WRF. The second pass of the FMS-sonic found the seafloor at $1795.2 \mathrm{~m}$ WRF, compared to the drillers mudline tagged at 1796.8 mbrf (Hole U1423B). Tides were negligible and seas were calm (maximum peak-to-peak heave of $20 \mathrm{~cm}$ ), giving little contribution to the offset between the FMS-sonic and the paleo combo downlog and uplog seafloor depths. The remaining difference possibly comes from wireline stretching. A reasonably good depth match of the open hole NGR logs between logging runs and with the core data was achieved using a seafloor of $1794.6 \mathrm{~m}$ WRF for paleo combo Pass 2 and $1794.2 \mathrm{~m}$ WRF for the second pass of the FMS-sonic.

\section{Logging data quality}

Tool calibration was performed both before and after the logging runs to ensure quality control. In Hole U1423B, borehole conditions were good with a baseline diameter (12-13 inches) close to the bit size (9.875 inches) (Fig. F37). Only a short section larger than 13 inches, although not exceeding 14 inches, was found between 157 and 167 mbsf. As a consequence of good borehole conditions and negligible heave during downhole logging data acquisition, log data quality is generally very good.

Agreement between physical properties data and logging data is excellent for the density and NGR logs along almost the entire borehole (Fig. F37, Columns 2 and 3). From $\sim 125$ mbsf to the pipe entrance, the uplog gamma ray data, however, deviates from the core NGR data to lower values and no longer overlaps with the downlog (Fig. F37, Column 2). The gamma ray and density data are corrected from borehole diameter, although as the caliper was closed over this interval, the data quality is no longer ensured. We related this shift to be the result of an artificial correction of the gamma ray signal from the borehole size, with the caliper reading a smaller hole diameter than the actual size. For the same reason, the density log shows slightly lower values than the core data over the same interval. The natural and spectral gamma ray and density downlogs should thus be preferred for interpretations over this interval (from $\sim 125 \mathrm{mbsf}$ to the pipe entrance). Also, natural and spectral gamma ray data recorded shallower than 80 mbsf should only be used qualitatively because of the attenuation of the signal through the pipe (Fig. F37). The resistivity curve worked well, except for some high-frequency noise on the uplog starting $\sim 40 \mathrm{~m}$ below the pipe and increasing uphole. The downlog should be preferred for interpretations.

The Magnetic Susceptibility Sonde tool diagnostics were normal during the runs. However, because of the very low magnetic susceptibility signal in the sediment, we were possibly operating at the lower limits of detection in the tool. The sensor electronics are sensitive to borehole temperature, and the acquired magnetic susceptibility data were thus strongly affected by a nonlinear long-period temperature-related drift superimposed on low signal variability. Preliminary processing was completed offshore to remove the temperature drift by calculating a least-squares polynomial fit to the data and subtracting the calculated trend from the data set. The residual components from both the high-resolution and deep readings are plotted in Figure F37 (Column 5) and should be an indication of the magnetic signal variability in the formation. The driftcorrected high-resolution log correlates relatively well with the magnetic susceptibility measurements on cores, especially shallower than $150 \mathrm{mbsf}$ and deeper than 205 mbsf. The corrected deep-reading low-resolution $\log$ is generally inversely correlated with the density log. Further processing remains necessary. The velocity log shows a downhole increasing trend with higher values than the $P$-wave velocities measured on cores, especially deeper than $180 \mathrm{mbsf}$ (Fig. F37, Column 6). The FMS resistivity images were of excellent quality because of good contact with the borehole wall (Fig. F38).

\section{Logging units}

The Hole U1423B logs change gradually downhole, with no major steps in base levels. The entire logged interval was thus assigned to one logging unit (LI; Fig. F37). At the scale of this unit, the upper part 
(from below pipe to $\sim 123 \mathrm{mbsf}$ ) is characterized by higher gamma ray, density, and resistivity than the rest of the hole. The sonic velocity log increases downhole, reflecting low sediment compaction with depth. Resistivity has a negative downhole gradient rather than the normal increasing downhole compaction trend (see below). Density decreases in the upper part of the hole and remains relatively flat deeper in the hole. The above log trends and their correlation with in situ lithologies (see below) are generally in good agreement with the logging data acquired during Legs 127 and 128 at ODP Sites 794B, 795, 797, and 798, which show similar patterns.

The Hostile Environment Natural Gamma Ray Sonde signal ranges on average from 20 to $45 \mathrm{gAPI}$, with peak values reaching 70 gAPI. The signal shows moderately high amplitude variability on a several-meter to submeter scale, and given the sedimentological context (see "Lithostratigraphy"), it most likely tracks clay and organic matter content (silica and calcite contain no radioactive elements). The potassium and thorium curves are generally well correlated (Fig. F38). Uranium behaves differently from potassium and thorium because it is not chemically combined in the main terrigenous minerals. It does, however, show locally good correlations with thorium and potassium, particularly where prominent peaks are observed in the total gamma ray log. Uranium generally accounts for $25 \%-45 \%$ of the total gamma radiation signal, and locally for $>50 \%$. Uranium is usually associated with the organic matterrich intervals in lithologic Unit I (above $\sim 82.5 \mathrm{mbsf}$, see "Lithostratigraphy"), in which it shows the highest values (see below). The uranium content remains relatively high in lithologic Unit II (from $\sim 82.5 \mathrm{mbsf}$ to the bottom of the hole), which is less rich in organic matter.

Logging Unit LI has been divided into two subunits on the basis of changes in character of gamma ray and density logs.

\section{Logging Subunit Lla: base of drill pipe ( $\sim 80 \mathrm{mbsf})$ to $\sim 124 \mathrm{mbsf}$}

The upper logging subunit is characterized by moderate to high-amplitude swings in NGR (and its U, Th, and $\mathrm{K}$ components), with an overall decreasing downhole trend. The gamma ray signal correlates well with the bulk density log, which shows highamplitude variations ranging from 1.25 to $1.55 \mathrm{~g} / \mathrm{cm}^{3}$ (Fig. F37). The sonic curve is relatively flat, with values generally increasing downhole. Below 103 mbsf, progressive decreases in $\mathrm{U}$, Th, and $\mathrm{K}$ contents are observed, likely reflecting a decrease in organic matter and clay content. Slightly higher values in $\mathrm{K}$ content are, however, observed between 107 and
115 mbsf (Fig. F38). The depth of 103 mbsf fits well with the transition between lithologic Unit I (primarily fine-grained material derived from terrigenous sources with color banding that is suggested to be related to variable content of organic matter and pyrite) and Unit II (dominantly composed of moderate to heavily bioturbated diatomaceous silty clay and clay and diatom ooze), placed in Section 346U1423A-12H-1 at $\sim 103.35 \mathrm{~m}$ CSF-A (see "Lithostratigraphy") and reflecting a significant downhole increase in diatom content relative to terrigenous sediment.

The main changes in character of the downhole logs have been correlated with the base of logging Subunit LIa, which approximates the depth of the lithologic Subunit IIA/IIB boundary, placed at $121 \mathrm{~m}$ CSF-A in Hole U1423A (Section 346-U1423A-14H-1) (see "Lithostratigraphy"). From a sedimentological point of view, however, no clear characteristic allowed straightforward division of lithologic Unit II into Subunits IIA and IIB. The relative decrease in NGR core and downhole log values was the basis for differentiating these two lithologic subunits (see also "Physical properties").

\section{Logging Subunit Llb: 124-250 mbsf}

Logging Subunit LIb is distinguished from logging Subunit LIa by lower values in total and spectral NGR, likely reflecting the abundance of nonradioactive elements within lithologic Subunit IIB (diatoms and other siliceous components, see "Lithostratigraphy"). Logging Subunit LIb is also characterized by moderate-amplitude swings in NGR and its $\mathrm{U}$, Th, and $\mathrm{K}$ components. Two prominent peaks in at least two of these components are observed at $\sim 142$ and 193 mbsf and correlate well with the NGR data measured on cores. The peak observed at 193 mbsf does not correlate with anything obvious in the cored sediment. The peak at $\sim 142$ mbsf may correspond to a prominent ash layer, which is $>10 \mathrm{~cm}$ thick (interval 346-U1423B-16H-6, 84-96 cm). This ash layer is also clearly associated with a peak in the density log. Another peak in density at $\sim 238 \mathrm{mbsf}$ also correlates with a thick ash layer in interval 346U1423B-27H-6, 23-33 cm, and a prominent peak in the NGR data measured on the core. Logging Subunit LIb is also distinguished from logging Subunit LIa by lower values in bulk density, showing a relatively uniform trend, with values $<1.45 \mathrm{~g} / \mathrm{cm}^{3}$ associated with lower amplitude oscillations compared to Subunit LIa. Sonic velocity increases downhole. At the borehole scale, the resistivity curves show an opposite trend to the sonic curve, with mean values decreasing downhole from 0.9 to $0.4 \Omega \mathrm{m}$, although this gradient becomes gentler in logging Subunit LIb. 
Similar downhole decreasing resistivity patterns have also been observed at Sites 794, 795, 797, and 798 (Ingle, Suyehiro, von Breymann, et al., 1990; Tamaki, Pisciotto, Allan, et al., 1990) and in the upper $300 \mathrm{~m}$ of the sediment column. This negative gradient is likely due to the increasing temperature with depth and the high porosities (see "Physical properties"), making the physical properties of the pore water dominate the resistivity log response. The prominent peak in magnetic susceptibility observed at 206 mbsf on both core and log data correlate well with a dark ash layer found in interval 346-U1423B$24 \mathrm{H}-4,129-131 \mathrm{~cm}$.

\section{FMS images}

Because of the good borehole conditions in Hole U1423B, the FMS resistivity data quality allows the borehole formation resistivity to be interpreted at several scales. At the scale of the borehole, the interval above 206 mbsf is characterized by relatively high conductivities (dark colored upper interval in the FMS image in Fig. F38) and high resistivities below (light color in the FMS image). This change does not correlate in core with any major change in lithology (see "Lithostratigraphy"). At a finer scale, the FMS images reveal numerous resistive and conductive intervals, with thicknesses ranging from several tens of centimeters to a few meters. As an example, the conductive intervals observed from 110 to 126 mbsf on the FMS images generally correlate with lower values in the gamma ray, bulk density, and resistivity logs (Fig. F40) and seem to correspond in cores, although not always, to brownish intervals. These intervals contrast with lighter, more grayish intervals that are less conductive on the FMS images and correlate with higher values in the NGR, bulk density, and resistivity logs. Transitions between alternations are mainly gradual, although some sharp contacts are observed locally. Inclined bedding (appearing as sinusoids) at slight angles is observed at some depths. It will be possible to map their occurrence and measure dip directions and angle. As shown in Figure F41, decimetric to centimetric resistive and conductive intervals are also clearly observed in the bottom part of the hole (234-243 mbsf) in an interval dominated by homogeneous lithology (diatomaceous silty clay and clay and diatomite ooze, see "Lithostratigraphy"). The conductive layers correlate in cores with intervals characterized by low gamma ray and high $\mathrm{L}^{*}$ values, possibly reflecting an increase in biosiliceous fraction content. These initial correlations need to be further examined by shore-based research. FMS resistivity images also reveal stratigraphic information at a finer spatial resolution than the standard logs. In Figure F41, the highly resistive layers around 236.4 and $238 \mathrm{mbsf}$ (with thicknesses $\sim 0.1 \mathrm{~m}$ ), correlate with two thick ash layers observed in intervals 346-U1423B-27H-5, $0-10 \mathrm{~cm}$, and $27 \mathrm{H}-6,23-33 \mathrm{~cm}$. Other ash layers are also observed at other depths on the FMS images (e.g., Fig. F40).

\section{In situ temperature and heat flow}

APCT-3 downhole temperature measurements were performed in Hole U1423A at five depths, including the mudline. In situ temperatures range from $5.50^{\circ} \mathrm{C}$ at $35.8 \mathrm{~m}$ CSF-A to $17.45^{\circ} \mathrm{C}$ at $121.3 \mathrm{~m}$ CSF-A (Table T17), with a linear downhole increase indicating that the gradient is uniform with depth (Fig. F42). A linear fit of temperature versus depth gives a geothermal gradient of $140^{\circ} \mathrm{C} / \mathrm{km}$. This value is higher than was measured at Site U1422 $\left(134^{\circ} \mathrm{C} / \mathrm{km}\right)$. The bottom water temperature at this site is estimated to be $0.47^{\circ} \mathrm{C}$, based on the average mudline temperature in the four APCT-3 measurements. A heat flow of $133 \mathrm{~mW} / \mathrm{m}^{2}$ was obtained from the slope of the linear fit between in situ temperature and calculated in situ thermal resistance (Pribnow et al., 2000). This value is also higher than the one calculated at Site $\mathrm{U} 1422\left(120 \mathrm{~mW} / \mathrm{m}^{2}\right)$.

\section{Stratigraphic correlation and sedimentation rates}

Real-time tracking of the relative positions of core gaps among the various holes at Site U1423 was accomplished using magnetic susceptibility and GRA data from the WRMSL and STMSL. Data were collected at resolutions of either 2.5 or $5 \mathrm{~cm}$, depending on the capacity to keep up with core recovery rates. Detailed (centimeter scale) compositing and splicing (see "Stratigraphic correlation and sedimentation rates" in the "Methods" chapter [Tada et al., 2015b]) are based on the high-resolution RGB (blue) color data recovered from the Section Half Imaging Logger at $0.5 \mathrm{~cm}$ resolution. For detailed discussion of these data sets, see "Physical properties" in the "Methods" chapter (Tada et al., 2015b).

After all cores were composited, a continuous splice was constructed spanning 0-218.8 m CCSF-D (as defined in the "Methods" chapter [Tada et al., 2015b]). All three holes were required to construct the splice; a combination of drilling disturbance and poor recovery within the interval from $\sim 144$ to $~ 184$ m CSFA prevented construction of a complete splice from Holes U1423A and U1423B alone. In addition, at three depths, between-core gaps in Holes U1423A and U1423B were aligned. Finally, a $6.5 \mathrm{~m}$ interval was also missing because of $0 \%$ recovery of Core 346- 
U1423B-18H. Consequently, a detailed drilling plan was constructed to recover these missing intervals in Hole U1423C, as described below. The resulting composite and splice ranges from the top of Core 346U1423A-1H to the bottom of Core 346-U1423B-24H at $218.8 \mathrm{~m}$ CCSF-D (211.2 m CSF-A) (Tables T18, T19; Fig. F43). Only Hole U1423B extends deeper than this depth, to Core 346-U1423B-28H at 256.9 $\mathrm{m}$ CCSF-A (249.3 m CSF-A). The length of the splice (218.8 $\mathrm{m}$ CCSF-D) relative to the length of the uncomposited section (211.2 m CSF-A) indicates that expansion at this site is minimal (3.8\%).

A CCSF-C scale (as defined in "Stratigraphic correlation and sedimentation rates" in the "Methods" chapter [Tada et al., 2015b]) was created for this site, extending to $\sim 90 \mathrm{~m} \mathrm{CSF-A,} \mathrm{covering} \mathrm{Subunit} \mathrm{IA}$ as defined in "Lithostratigraphy." Construction of the CCSF-C scale is based on centimeter-scale correlation of structure in the RGB (blue) data. These CCSF-C depth maps (CSF-A to CCSF-D) are provided for Holes U1423A and U1423B in Table T20.

\section{Detailed drilling at Hole U1423C to recover between-core gaps}

Hole U1423C was selectively cored to recover sections not recovered in Holes U1423A and U1423B. Hole U1423C was drilled without recovery to $\sim 114$ $\mathrm{m}$ CSF-A. This $114 \mathrm{~m}$ washed interval is designated in the coring sequence as Core $346-\mathrm{U} 1423 \mathrm{C}-11$, as required by IODP terminology. The suffix " 11 " refers to Core " 1 " drilled Interval " 1. " The wash interval was followed by two APC cores $(2 \mathrm{H}$ and $3 \mathrm{H})$ to establish the stratigraphic relationship relative to Holes U1423A and U1423B. The next APC core $(4 \mathrm{H})$ successfully recovered the first of the three targeted gaps. While the stratigraphic correlation was taking place, the bit was held at the top of the previously cored interval in order to minimize disturbance at the top of the following core. Following stratigraphic correlation, the bit was advanced the length of the previously recovered core (referred to on the rig floor as "cleaning out the rathole") and the hole was washed an additional $7.5 \mathrm{~m}$ (Core 52 [drilled Interval 2 in Core 5]) in order to place the APC such that it would recover the missing $6.5 \mathrm{~m}$ interval in the middle of the following $9.6 \mathrm{~m}$ stroke. Following recovery of this interval, the hole was washed another $2 \mathrm{~m}$ (Core 73 [drilled Interval 3 in Core 7]) in order to place the last two gaps in the middle of the next two APC strokes. After successful recovery of these last two remaining gaps, the hole was terminated. The success of this detailed drilling effort was greatly aided by ideal conditions: near zero heave and a sediment lithology conducive to full stroke recovery with little to no expansion. This targeted approach resulted in considerable time savings, compared to coring the entire hole top to bottom.

\section{Age model and sedimentation rates}

A preliminary age model (Fig. F44) was established on the basis of all available biostratigraphic and paleomagnetic age control points. For details, see "Biostratigraphy," "Paleomagnetism," and "Lithostratigraphy." At this site, no datums were excluded from the assessment, although three datums defined as the LOs of Proboscia curvirostris and Actinocyclus oculatus and the rapid decrease of Siphocampe arachnea group could be affected by reworking. Eight linear depth-age segments utilizing all the paleomagenetic events as well as the FO of Neodenticula koizumii, and the LO of Thalassiosira jacksonii provide a wellconstrained preliminary age model (Fig. F44A). Sedimentation rate (Fig. F44B) ranges from 21 to $121 \mathrm{~m} /$ m.y., moderate in the upper Subunit IA, low in the lower Subunit IA and Subunit IIA, and high in Subunits IB and IIB, possibly reflecting the change in siliceous productivity. Estimated ages of subunit boundaries are 1.8, 2.2, and 3.0 Ma for the Subunit IA/IB, IB/IIA, and IIA/IIB boundaries, respectively.

\section{References}

Adkins, J.F., McIntyre, K., and Schrag, D.P., 2002. The salinity, temperature, and $\delta^{18} \mathrm{O}$ of the glacial deep ocean. Science, 298(5599):1769-1773. doi:10.1126/ science.1076252

Backman, J., Moran, K., McInroy, D.B., Mayer, L.A., and the Expedition 302 Scientists, 2006. Proc. IODP, 302: Edinburgh (Integrated Ocean Drilling Program Management International, Inc.). doi:10.2204/ iodp.proc.302.2006

Berner, R.A., 1980. Early Diagenesis: A Theoretical Approach: Princeton, NJ (Princeton Univ. Press).

Berner, R.A., 1981. A new geochemical classification of sedimentary environments. J. Sediment. Res., 51(2):359365. doi:10.1306/212F7C7F-2B24-11D78648000102C1865D

Bernhard, J.M., Goldstein, S.T., and Bowser, S.S., 2010. An ectobiont-bearing foraminiferan, Bolivina pacifica, that inhabits microxic pore waters: cell-biological and paleoceanographic insights. Environ. Microbiol., 12(8):21072119. doi:10.1111/j.1462-2920.2009.02073.x

Bernhard, J.M., and Sen Gupta, B.K., 1999. Foraminifera of oxygen-depleted environments. In Sen Gupta, B.K., (Ed.), Modern Foraminifera: Dordrecht (Kluwer Academic Publishers), 201-216. doi:10.1007/0-306-48104-9_12

Blum, P., 1997. Physical properties handbook: a guide to the shipboard measurement of physical properties of deep-sea cores. ODP Tech. Note, 26. doi:10.2973/ odp.tn.26.1997

Brady, G.S., 1880. Report on the Ostracoda dredged by HMS Challenger during the years 1873-76. Rep. Sci. 
Results of the Voyage of HMS Challenger during the years 1873-76, Zoology, 3:1-184.

Brumsack, H.-J., and Zuleger, E., 1992. Boron and boron isotopes in pore waters from ODP Leg 127, Sea of Japan. Earth Planet. Sci. Lett., 113(3):427-433. doi:10.1016/ 0012-821X(92)90143-J

Cha, H.J., Lee, C.B., Kim, B.S., Choi, M.S., and Ruttenberg, K.C., 2005. Early diagenetic redistribution and burial of phosphorus in the sediments of the southwestern East Sea (Japan Sea). Mar. Geol., 216(3):127-143. doi:10.1016/j.margeo.2005.02.001

Föllmi, K.B., Cramp, A., Föllmi, K.E., Alexandrovich, J.M., Brunner, C., Burckle, L.H., Casey, M., deMenocal, P., Dunbar, R.B., Grimm, K.A., Holler, P., Ingle, J.C., Jr., Kheradyar, T., McEvoy, J., Nobes, D.C., Stein, R., Tada, R., von Breymann, M.T., and White, L.D., 1992. Darklight rhythms in the sediments of the Japan Sea: preliminary results from Site 798, with some additional results from Sites 797 and 799. In Pisciotto, K.A., Ingle, J.C., Jr., von Breymann, M.T., Barron, J., et al., Proc. ODP, Sci. Results, 127/128 (Pt. 1): College Station, TX (Ocean Drilling Program), 559-576. doi:10.2973/ odp.proc.sr.127128-1.159.1992

Föllmi, K.B., and von Breymann, M., 1992. Phosphates and glauconites of Sites 798 and 799. In Pisciotto, K.A., Ingle, J.C., Jr., von Breymann, M.T., Barron, J., et al., Proc. ODP, Sci. Results, 127/128 (Pt. 1): College Station, TX (Ocean Drilling Program), 63-74. doi:10.2973/ odp.proc.sr.127128-1.116.1992

Froelich, P.N., Klinkhammer, G.P., Bender, M.L., Luedtke, N.A., Heath, G.R., Cullen, D., Dauphin, P., Hammond, D., Hartman, B., and Maynard, V., 1979. Early oxidation of organic matter in pelagic sediments of the eastern equatorial Atlantic: suboxic diagenesis. Geochim. Cosmochim. Acta, 43(7):1075-1090. doi:10.1016/00167037(79)90095-4

Gieskes, J.M., and Lawrence, J.R., 1981. Alteration of volcanic matter in deep-sea sediments: evidence from the chemical composition of interstitial waters from deep sea drilling cores. Geochim. Cosmochim. Acta, 45(10):1687-1703. doi:10.1016/ 0016-7037(81)90004-1

Hanai, T., Ikeya, N., and Yajima, M., 1980. Deep-sea Ostracoda from Deep Sea Drilling Project Site 435, Japan Trench. In Scientific Party, Init. Repts. DSDP, 56/57 (Pt. 2): Washington (U.S. Govt. Printing Office), 907909. doi:10.2973/dsdp.proc.5657.130.1980

Ingle, J.C., Jr., Suyehiro, K., von Breymann, M.T., et al., 1990. Proc. ODP, Init. Repts., 128: College Station, TX (Ocean Drilling Program). doi:10.2973/ odp.proc.ir.128.1990

Kucera, M., and Kennett, J.P., 2000. Biochronology and evolutionary implications of late Neogene California margin planktonic foraminiferal events. Mar. Micropaleontol., 40(1-2):67-81. doi:10.1016/ S0377-8398(00)00029-3

Machida, H., and Arai, F., 2003. Atlas of Tephras in and around Japan (revised ed.): Tokyo (Univ. Tokyo Press).

Maiya, S., 1978. Late Cenozoic planktonic foraminiferal biostratigraphy of the oil-field region of northeast
Japan. In Cenozoic Geology of Japan: Osaka, 35-60. (in Japanese, with abstract in English)

Malone, M.J., Claypool, G., Martin, J.B., and Dickens, G.R., 2002. Variable methane fluxes in shallow marine systems over geologic time: the composition and origin of pore waters and authigenic carbonates on the New Jersey shelf. Mar. Geol., 189(3-4):175-196. doi:10.1016/ S0025-3227(02)00474-7

Masuzawa, T., and Kitano, Y., 1983. Interstitial water chemistry in deep-sea sediments from the Japan Sea. J. Oceanogr. Soc. Jpn., 39(4):171-184. doi:10.1007/ BF02070261

Masuzawa, T., and Kitano, Y., 1984. Appearance of $\mathrm{H}_{2} \mathrm{~S}$ bearing bottom waters during the last glacial period in the Japan Sea. Geochem. J., 18(4):167-172. doi:10.2343/ geochemj.18.167

Matsumoto, R., 1992. Diagenetic dolomite, calcite, rhodochrosite, magnesite, and lansfordite from Site 799, Japan Sea-implications for depositional environments and the diagenesis of organic-rich sediments. In Pisciotto, K.A., Ingle, J.C., Jr., von Breymann, M.T., Barron, J., et al., Proc. ODP, Sci. Results, 127/128 (Pt. 1): College Station, TX (Ocean Drilling Program), 75-98. doi:10.2973/odp.proc.sr.127128-1.119.1992

Middelburg, J.J., de Lange, G.J., and van der Weijden, C.H., 1987. Manganese solubility control in marine pore waters. Geochim. Cosmochim. Acta, 51(3):759-763. doi:10.1016/0016-7037(87)90086-X

Miwa, M., 2014. Foraminifera. In Sekiyu Kogyo Binran (Petroleum Technology Handbook) 2013: Tokyo (Jpn. Assoc. Pet. Technol.), 223-227 (in Japanese).

Murray, R.W., Brumsack, H.J., von Breymann, M.T., Sturz, A.A., Dunbar, R.B., and Gieskes, J.M., 1992. Diagenetic reactions in deeply buried sediments of the Japan Sea: a synthesis of interstitial-water chemistry results from Legs 127 and 128. In Tamaki, K., Suyehiro, K., Allan, J., McWilliams, M., et al., Proc. ODP, Sci. Results, 127/128 (Pt. 2): College Station, TX (Ocean Drilling Program), 1261-1274. doi:10.2973/odp.proc.sr.1271282.177.1992

Oba, T., Kato, M., Kitazato, H., Koizumi, I., Omura, A., Sakai, T., and Takayama, T., 1991. Paleoenvironmental changes in the Japan Sea during the last 85,000 years. Paleoceanography, 6(4):499-518. doi:10.1029/ 91PA00560

Pribnow, D., Kinoshita, M., and Stein, C., 2000. Thermal Data Collection and Heat Flow Recalculations for Ocean Drilling Program Legs 101-180: Hanover, Germany (Inst. Joint Geosci. Res., Inst. Geowiss. Gemeinschaftsauf. [GGA]). http://www-odp.tamu.edu/publications/ heatflow/ODPReprt.pdf

Satoguchi, Y., and Nagahashi, Y., 2012. Tephrostratigraphy of the Pliocene to middle Pleistocene series in Honshu and Kyushu Islands, Japan. Isl. Arc, 21(3):149-169. doi:10.1111/j.1440-1738.2012.00816.x

Schrag, D.P., Hampt, G., and Murray, D.W., 1996. Pore fluid constraints on the temperature and oxygen isotopic composition of the glacial ocean. Science, 272(5270):1930-1932. doi:10.1126/science.272.5270.1930 
Shumway, G., 1958. Sound velocity vs. temperature in water-saturated sediments. Geophysics, 23(3):494-505. doi:10.1190/1.1438495

Sudo, H., 1986. A note on the Japan Sea Proper Water. Prog. Oceanogr., 17(3-4):313-336. doi:10.1016/0079. 6611(86)90052-2

Tada, R., 1994. Paleoceanographic evolution of the Japan Sea. Palaeogeogr., Palaeoclimatol., Palaeoecol., 108(34):487-508. doi:10.1016/0031-0182(94)90248-8

Tada, R., and Iijima, A., 1992. Lithostratigraphy and compositional variation of Neogene hemipelagic sediments in the Japan Sea. In Tamaki, K., Suyehiro, K., Allan, J., McWilliams, M., et al., Proc. ODP, Sci. Results, 127/128 (Pt. 2): College Station, TX (Ocean Drilling Program), 1229-1260. doi:10.2973/odp.proc.sr.1271282.188.1992

Tada, R., Koizumi, I., Cramp, A., and Rahman, A., 1992. Correlation of dark and light layers, and the origin of their cyclicity in the Quaternary sediments from the Japan Sea. In Pisciotto, K.A., Ingle, J.C., Jr., von Breymann, M.T., Barron, J., et al., Proc. ODP, Sci. Results, 127/ 128 (Pt. 1): College Station, TX (Ocean Drilling Program), 577-601. doi:10.2973/odp.proc.sr.1271281.160.1992

Tada, R., Murray, R.W., Alvarez Zarikian, C.A., Anderson, W.T., Jr., Bassetti, M.-A., Brace, B.J., Clemens, S.C., da Costa Gurgel, M.H., Dickens, G.R., Dunlea, A.G., Gallagher, S.J., Giosan, L., Henderson, A.C.G., Holbourn, A.E., Ikehara, K., Irino, T., Itaki, T., Karasuda, A., Kinsley, C.W., Kubota, Y., Lee, G.S., Lee, K.E., Lofi, J., Lopes, C.I.C.D., Peterson, L.C., Saavedra-Pellitero, M., Sagawa, T., Singh, R.K., Sugisaki, S., Toucanne, S., Wan, S., Xuan, C., Zheng, H., and Ziegler, M., 2015a. Expedition 346 summary. In Tada, R., Murray, R.W., Alvarez Zarikian, C.A., and the Expedition 346 Scientists, Proc. IODP, 346: College Station, TX (Integrated Ocean Drilling Program). doi:10.2204/iodp.proc.346.101.2015

Tada, R., Murray, R.W., Alvarez Zarikian, C.A., Anderson, W.T., Jr, Bassetti, M.-A., Brace, B.J., Clemens, S.C., Dickens, G.R., Dunlea, A.G., Gallagher, S.J., Giosan, L., da Costa Gurgel, M.H., Henderson, A.C.G., Holbourn, A.E., Ikehara, K., Irino, T., Itaki, T., Karasuda, A., Kinsley, C.W., Kubota, Y., Lee, G.S., Lee, K.E., Lofi, J., Lopes, C.I.C.D., Peterson, L.C., Saavedra-Pellitero, M., Sagawa, T., Singh, R.K., Sugisaki, S., Toucanne, S., Wan, S., Xuan, C., Zheng, H., and Ziegler, M., 2015b. Methods. In Tada, R., Murray, R.W., Alvarez Zarikian, C.A., and the Expedition 346 Scientists, Proc. IODP, 346: College Station, TX (Integrated Ocean Drilling Program). doi:10.2204/ iodp.proc.346.102.2015

Tada, R., Murray, R.W., Alvarez Zarikian, C.A., Anderson, W.T., Jr., Bassetti, M.-A., Brace, B.J., Clemens, S.C., da Costa Gurgel, M.H., Dickens, G.R., Dunlea, A.G., Gallagher, S.J., Giosan, L., Henderson, A.C.G., Holbourn, A.E., Ikehara, K., Irino, T., Itaki, T., Karasuda, A., Kinsley,
C.W., Kubota, Y., Lee, G.S., Lee, K.E., Lofi, J., Lopes, C.I.C.D., Peterson, L.C., Saavedra-Pellitero, M., Sagawa, T., Singh, R.K., Sugisaki, S., Toucanne, S., Wan, S., Xuan, C., Zheng, H., and Ziegler, M., 2015c. Site U1422. In Tada, R., Murray, R.W., Alvarez Zarikian, C.A., and the Expedition 346 Scientists, Proc. IODP, 346: College Station, TX (Integrated Ocean Drilling Program). doi:10.2204/iodp.proc.346.103.2015

Talley, L.D., Lobanov, V., Ponomarev, V., Salyuk, A., Tishchenko, P., Zhabin, I., and Riser, S., 2003. Deep convection and brine rejection in the Japan Sea. Geophys. Res. Lett., 30(4):1159. doi:10.1029/2002GL016451

Tamaki, K., Pisciotto, K., Allan, J., et al., 1990. Proc. ODP, Init. Repts., 127: College Station, TX (Ocean Drilling Program). doi:10.2973/odp.proc.ir.127.1990

Tamaki, K., Suyehiro, K., Allan, J., Ingle, J.C., Jr., and Pisciotto, K.A., 1992. Tectonic synthesis and implications of Japan Sea ODP drilling. In Tamaki, K., Suyehiro, K., Allan, J., McWilliams, M., et al., Proc. ODP, Sci. Results, 127/128 (Pt. 2): College Station, TX (Ocean Drilling Program), 1333-1348. doi:10.2973/odp.proc.sr.1271282.240.1992

van Geldern, R., Hayashi, T., Böttcher, M.E., Mottl, M.J., Barth, J.A.C., and Stadler, S., 2013. Stable isotope geochemistry of pore waters and marine sediments from the New Jersey shelf: methane formation and fluid origin. Geosphere, 9(1):96-112. doi:10.1130/GES00859.1

Wilkin, R.T., and Arthur, M.A., 2001. Variations in pyrite texture, sulphur isotope composition, and iron systematics in the Black Sea: evidence for the late Pleistocene to Holocene excursions of the $\mathrm{O}_{2}-\mathrm{H}_{2} \mathrm{~S}$ redox transition. Geochim. Cosmochim. Acta, 65(9):1399-1416. doi:10.1016/S0016-7037(01)00552-X

Wilkin, R.T., Arthur, M.A., and Dean, W.E., 1997. History of water-column anoxia in the Black Sea indicated by pyrite framboid size distributions. Earth Planet. Sci. Lett., 148(3-4):517-525. doi:10.1016/S0012821X(97)00053-8

Wilkin, R.T., Barnes, H.L., and Brantley, S.L., 1996. The size distribution of framboidal pyrite in modern sediments: an indicator of redox conditions. Geochim. Cosmochim. Acta, 60(20):3897-3912. doi:10.1016/00167037(96)00209-8

Xuan, C., and Channell, J.E.T., 2009. UPmag: MATLAB software for viewing and processing $U$ channel or other pass-through paleomagnetic data. Geochem., Geophys., Geosyst., 10(10):Q10Y07. doi:10.1029/2009GC002584

Yoon, J.-H., and Kim, Y.-J., 2009. Review on the seasonal variation of the surface circulation in the Japan/East Sea. J. Mar. Syst., 78(2):226-236. doi:10.1016/ j.jmarsys.2009.03.003

Publication: 28 March 2015 MS 346-104 
Figure F1. Bathymetric map of Expedition 346 sites (red circles) in the marginal sea surrounded by the Japanese Islands, the Korean Peninsula, and the Eurasian continent and the East China Sea. Sites previously drilled by the Deep Sea Drilling Project (DSDP) and Ocean Drilling Program (ODP) (white circles) are also shown. Also illustrated are surface current systems within and surrounding this marginal sea.

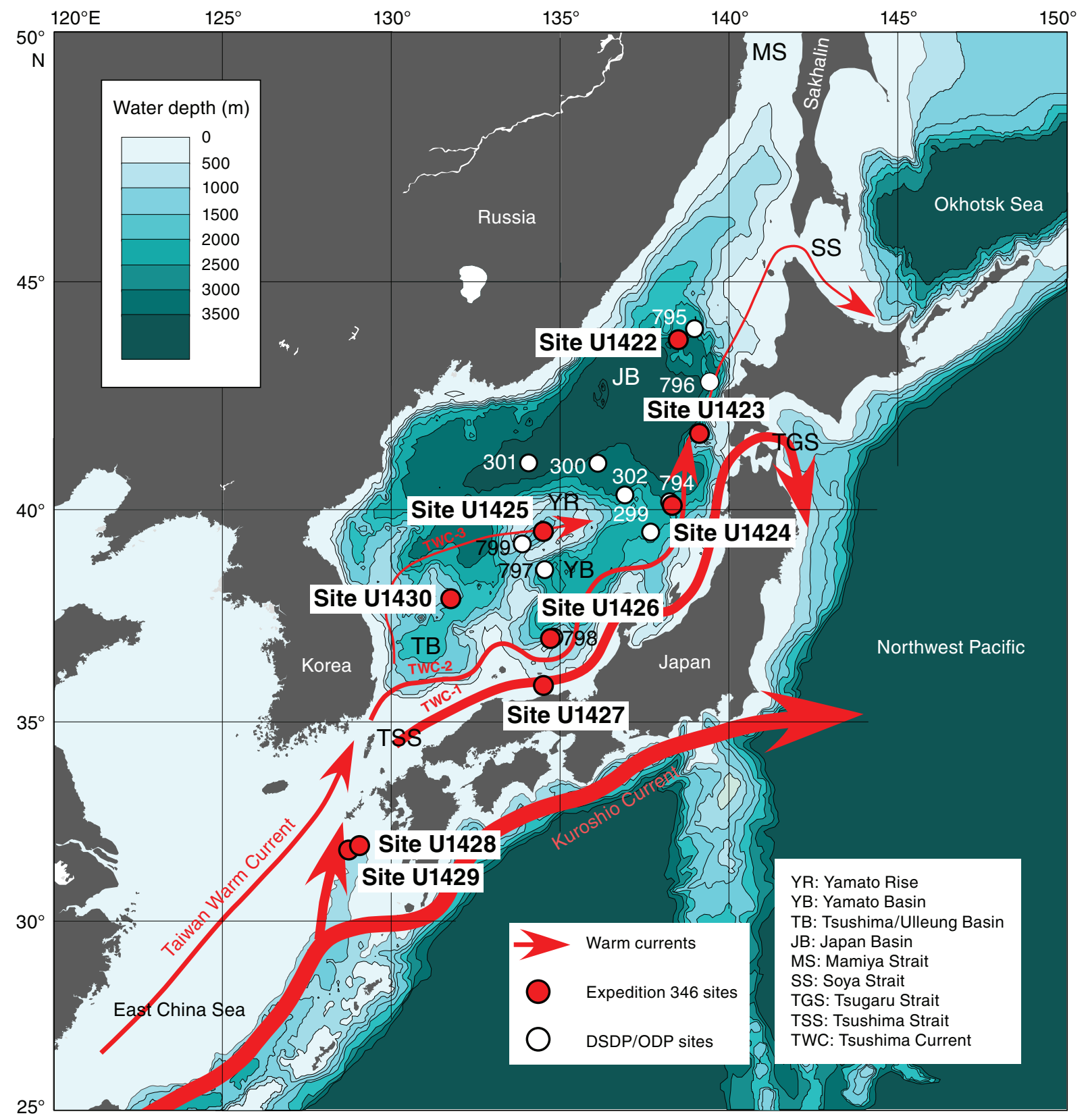


Figure F2. Lithologic summary, Hole U1423A. GRA = gamma ray attenuation.

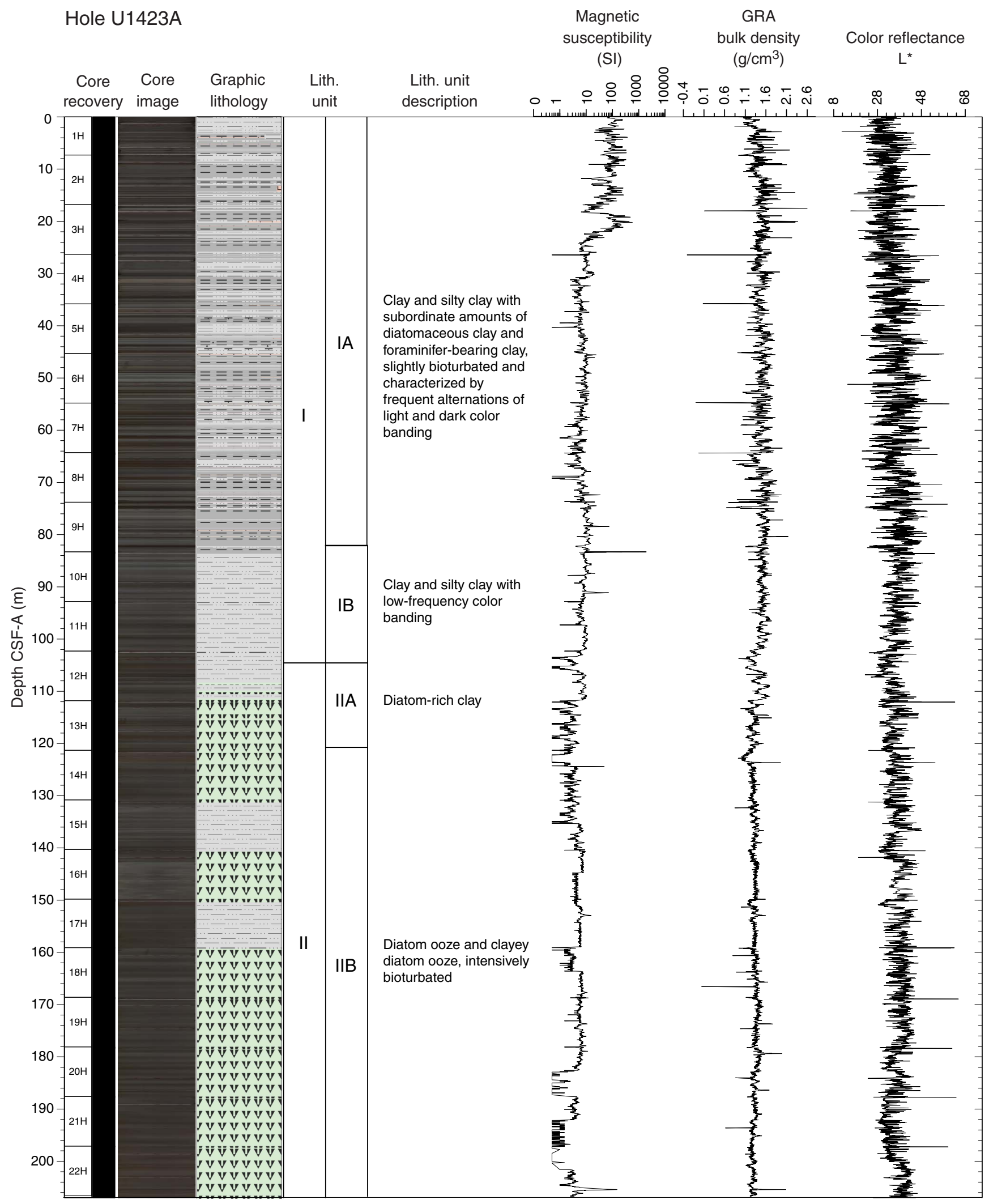


Figure F3. Lithologic summary, Hole U1423B. GRA = gamma ray attenuation.

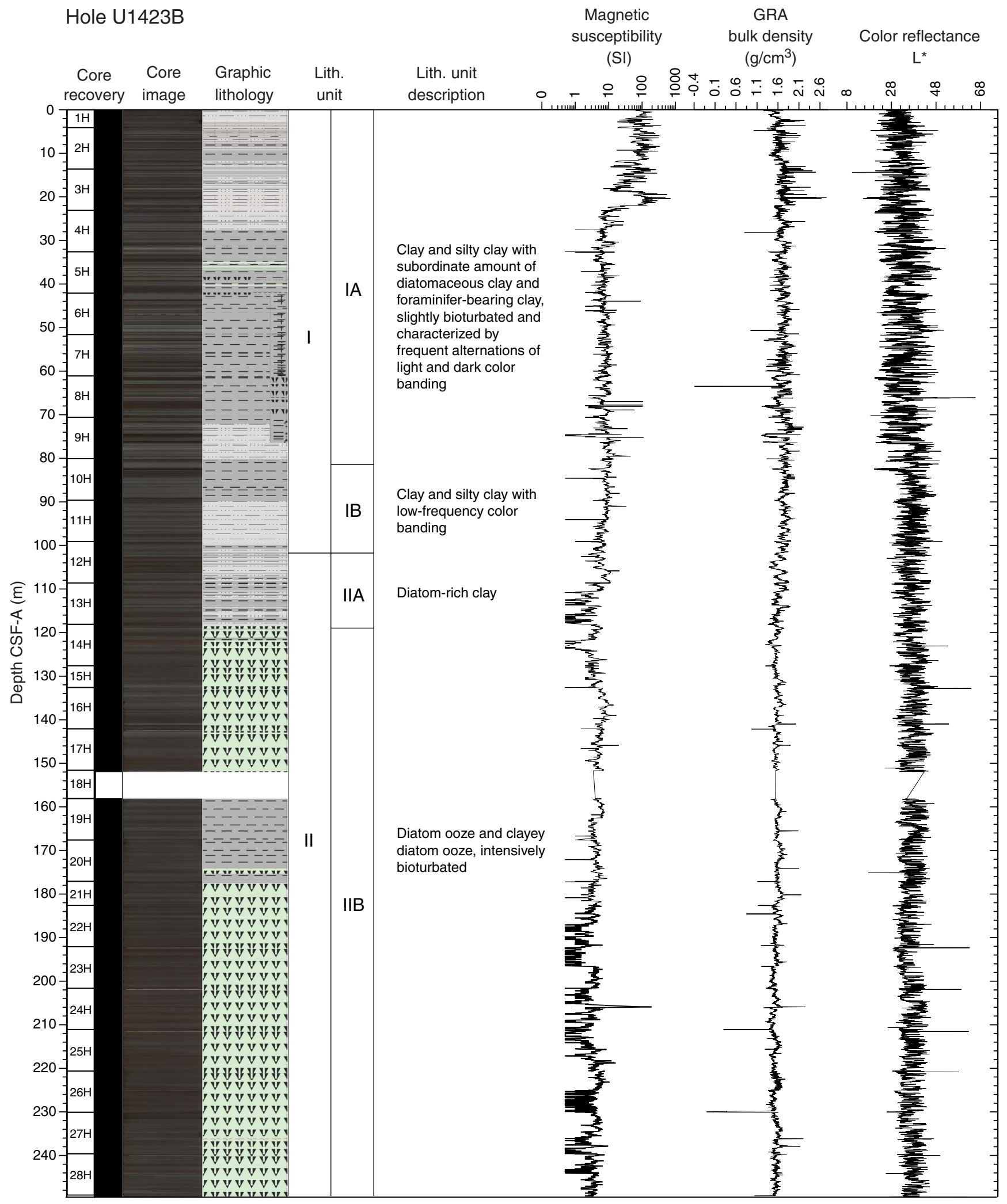


Figure F4. Lithologic summary, Hole U1423C. GRA = gamma ray attenuation.

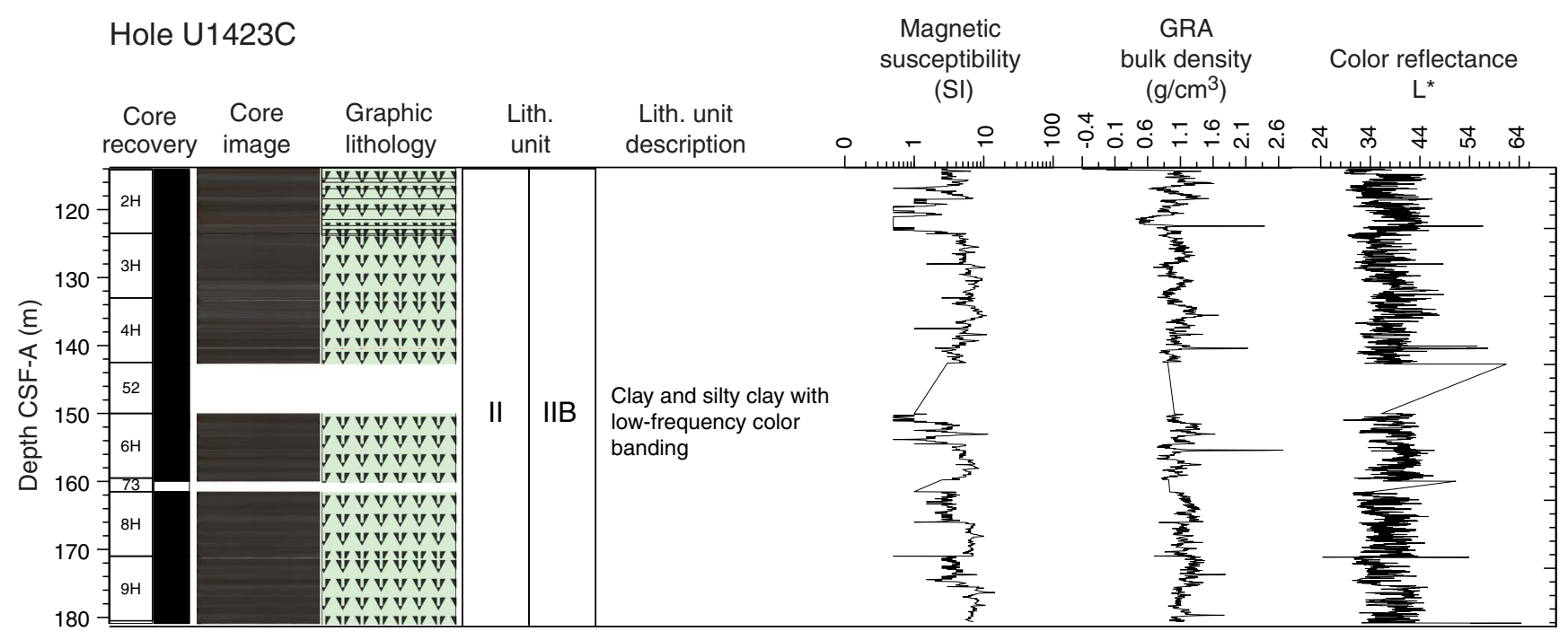


Figure F5. Hole-to-hole lithostratigraphic correlation, Site U1423.

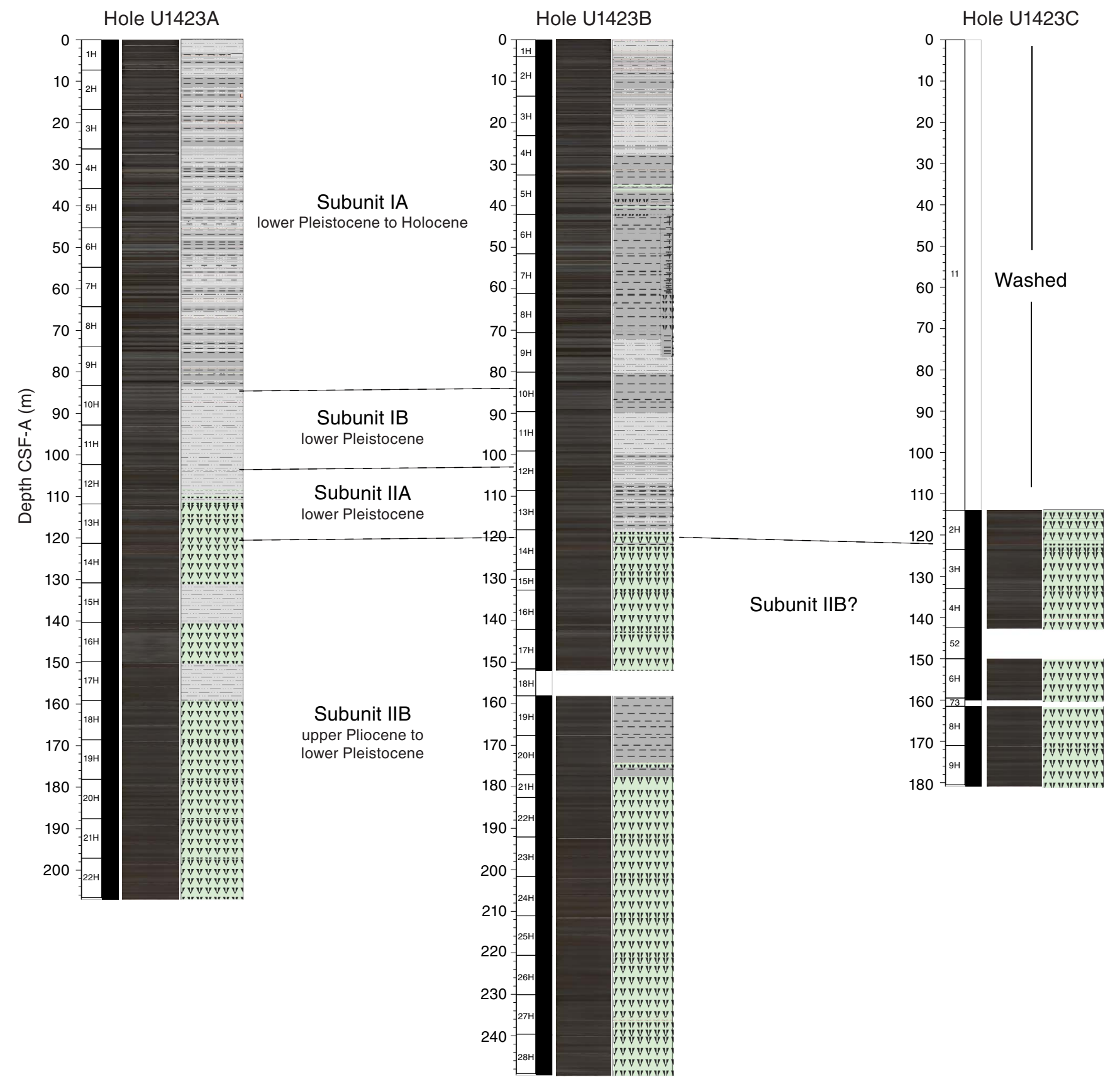


Figure F6. Number of visible tephra layers $(>0.5 \mathrm{~cm}$ thick) and their total thickness in each core, in Hole U1423A.

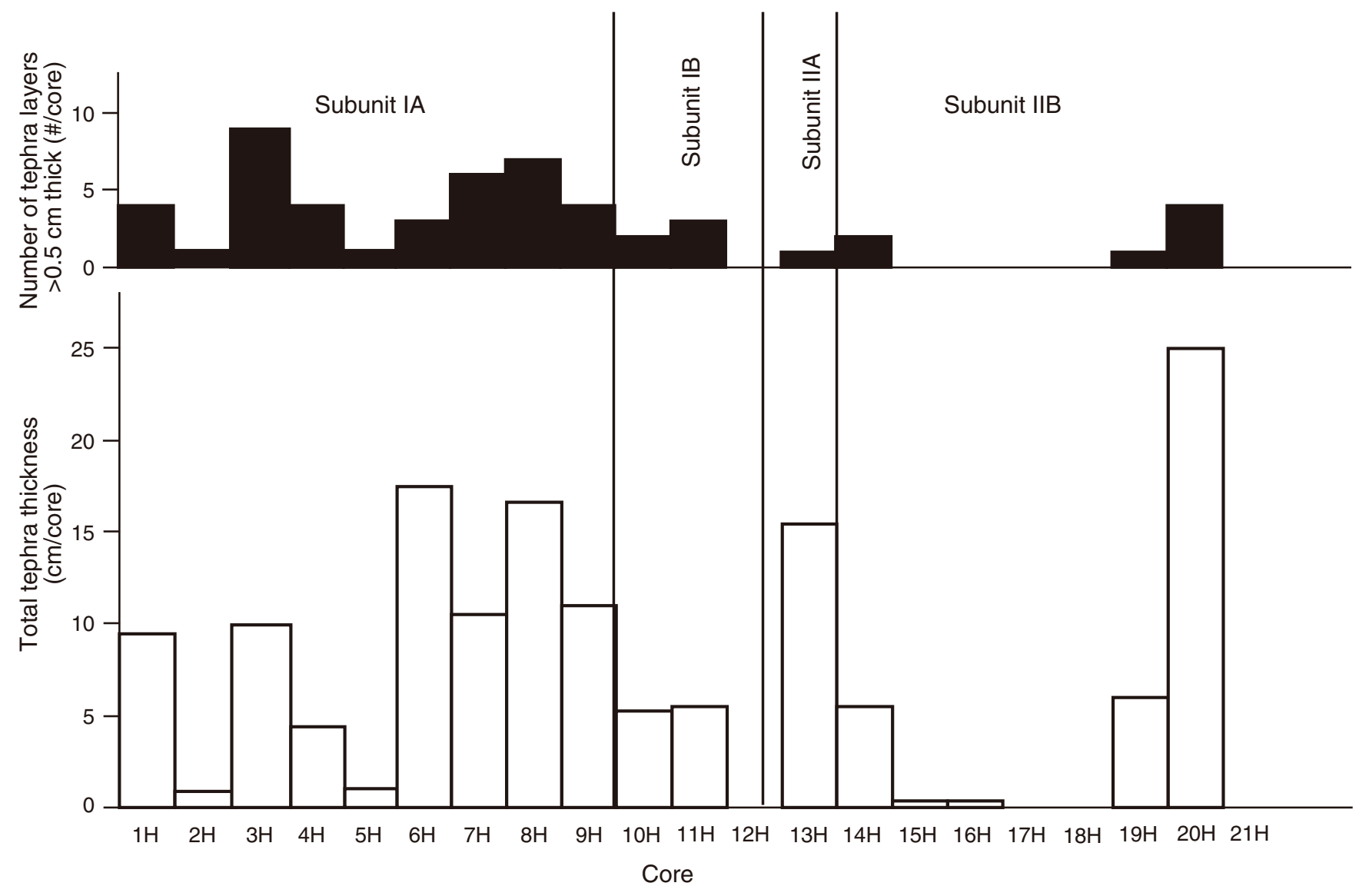


Figure F7. Variation of XRD peak intensities of identified minerals with depth, Hole U1423A.

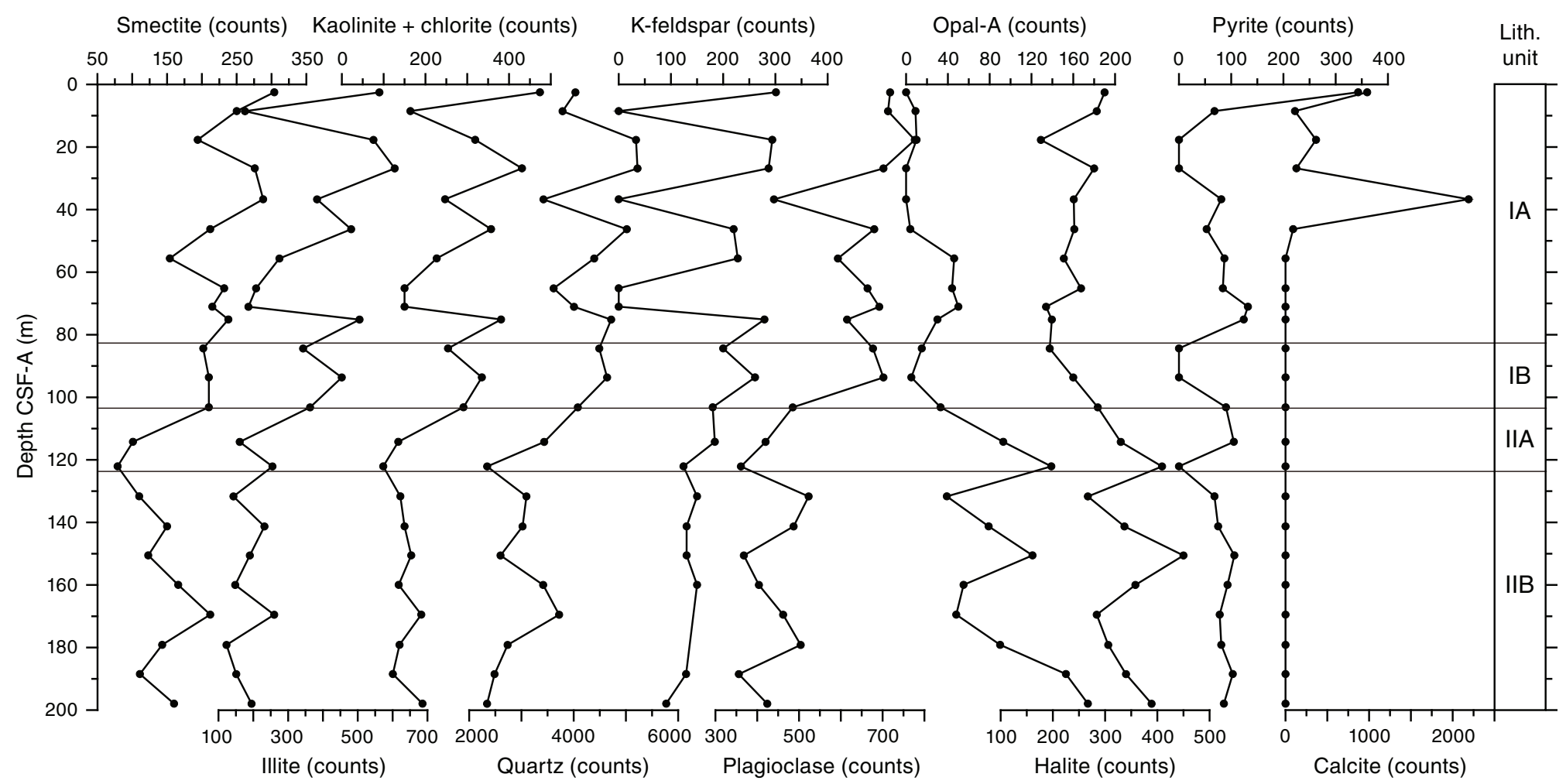


Figure F8. Photographs representative of Subunit IA in Holes U1423A and U1423B. Note enhanced color contrast to highlight sedimentary structures.

Hole U1423A/B

Subunit IA

$$
\text { U1423B-1H-2 }
$$

1.50-3.00 m CSF-A

\begin{abstract}
U1423A-4H-4 30.75-32.25 m CSF-A
\end{abstract}

\title{
U1423B-5H-3 35.60-37.10 m CSF-A
}

U1423A-5H-3 38.80-40.30 m CSF-A

U1423A-5H-5 41.80-43.30 m CSF-A

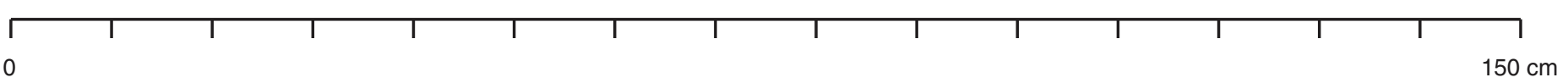


Figure F9. Foraminifer-rich nannofossil clay at $93 \mathrm{~cm}$ in laminated dark brown interval (346-U1423A-4H-4, 85$105 \mathrm{~cm})$.

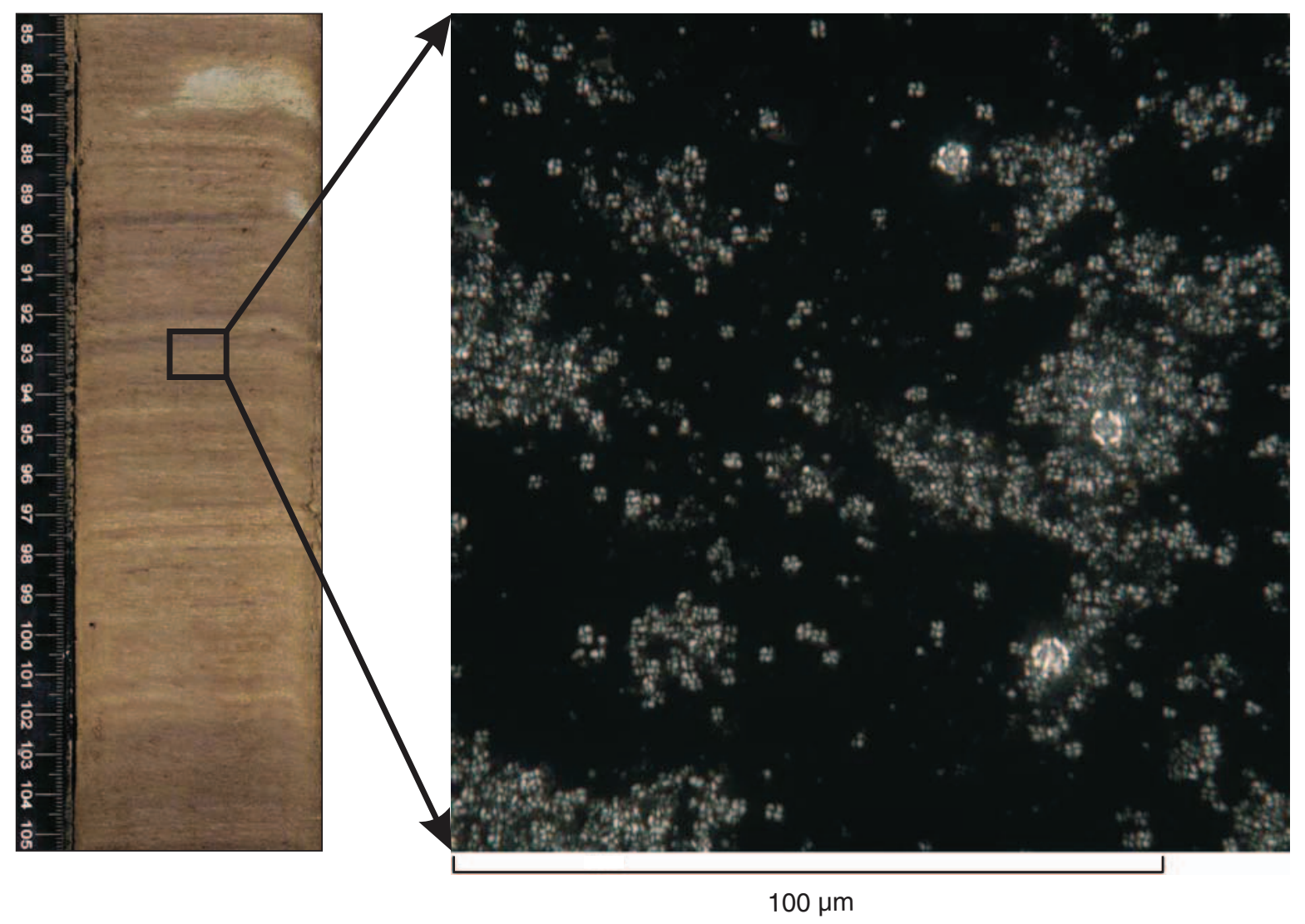


Figure F10. Photographs representative of Subunit IB in Holes U1423A and U1423B. Note enhanced color contrast to highlight sedimentary structures.

Hole U1423A/B

Subunit IB

\title{
$\mathrm{U} 1423 \mathrm{~A}-9 \mathrm{H}-2$
} 75.30-76.80 m CSF-A

\section{U1423B-9H-5 76.60-78.10 m CSF-A}

\author{
U1423A-9H-4 \\ 78.30-79.80 m CSF-A
}

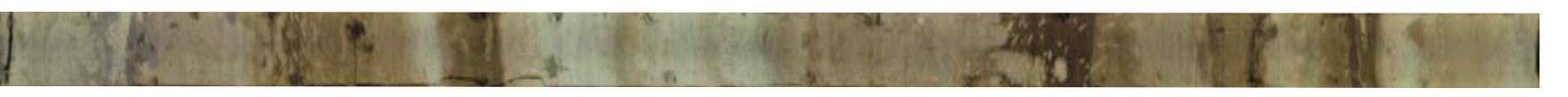

U1423A-10H-2 84.80-86.30 m CSF-A

U1423A-11H-1 92.80-94.30 m CSF-A

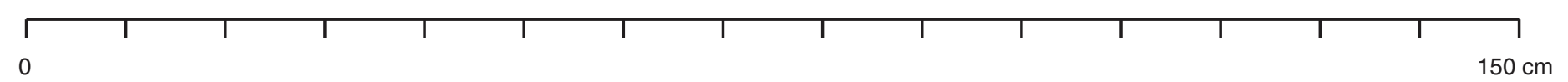


Figure F11. Photographs representative of Subunit IIA in Hole U1423A. Note enhanced color contrast to highlight sedimentary structures.

Hole U1423A

Subunit IIA

U1423A-12H-5 108.30-109.80 m CSF-A

U1423A-12H-6 109.80-111.30 m CSF-A

U1423A-13H-1 111.80-113.30 m CSF-A

U1423A-13H-4 116.30-117.80 m CSF-A

U1423A-13H-6 119.30-120.80 m CSF-A

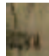


Figure F12. Photographs representative of Subunit IIB in Hole U1423A. Note enhanced color contrast to highlight sedimentary structures.

Hole U1423A

Subunit IIB

U1423A-15H-5 136.80-138.31 m CSF-A

U1423A-18H-5 165.10-166.60 m CSF-A

U1423A-19H-5 174.60-176.10 m CSF-A

U1423A-20H-3 181.10-182.60 m CSF-A

U1423A-20H-5 184.10-185.60 m CSF-A

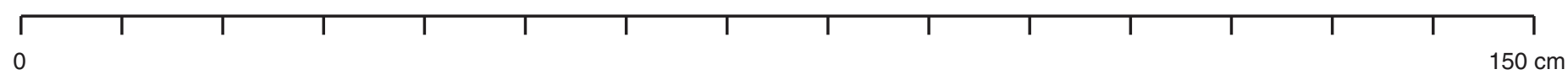


Figure F13. Normal graded tephra layer observed in hemipelagic diatom ooze composed by bubble-junction type glass shards (interval 346-U1423A-20H-6, 70-98 cm). v.f.s. = very fine sand, f.s. = fine sand.

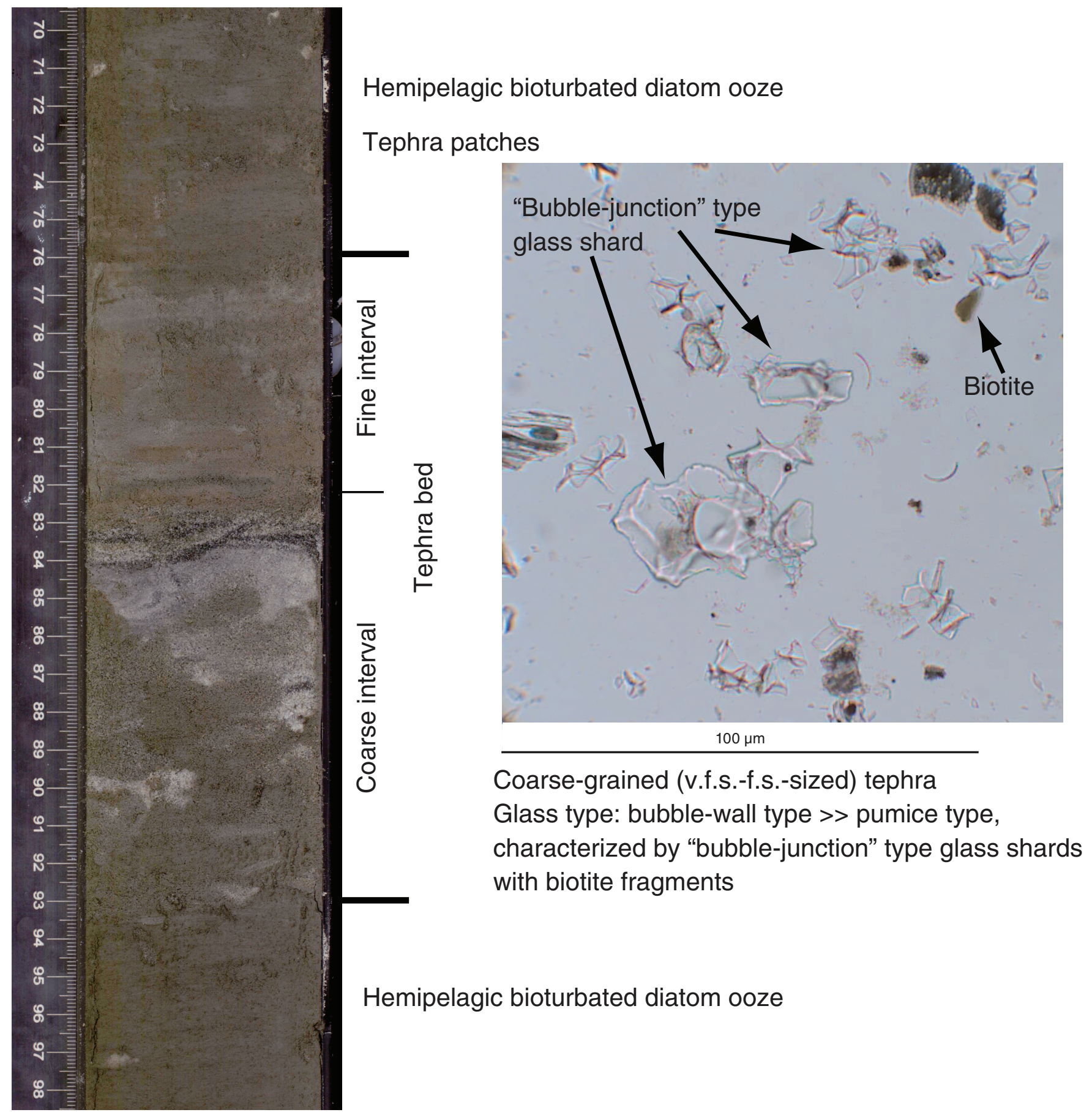


Figure F14. Downhole plots of measured total organic carbon (TOC), opal-A from XRD, and natural gamma radiation (NGR), Holes U1423A and U1423B. The corresponding lithologic units are identified.

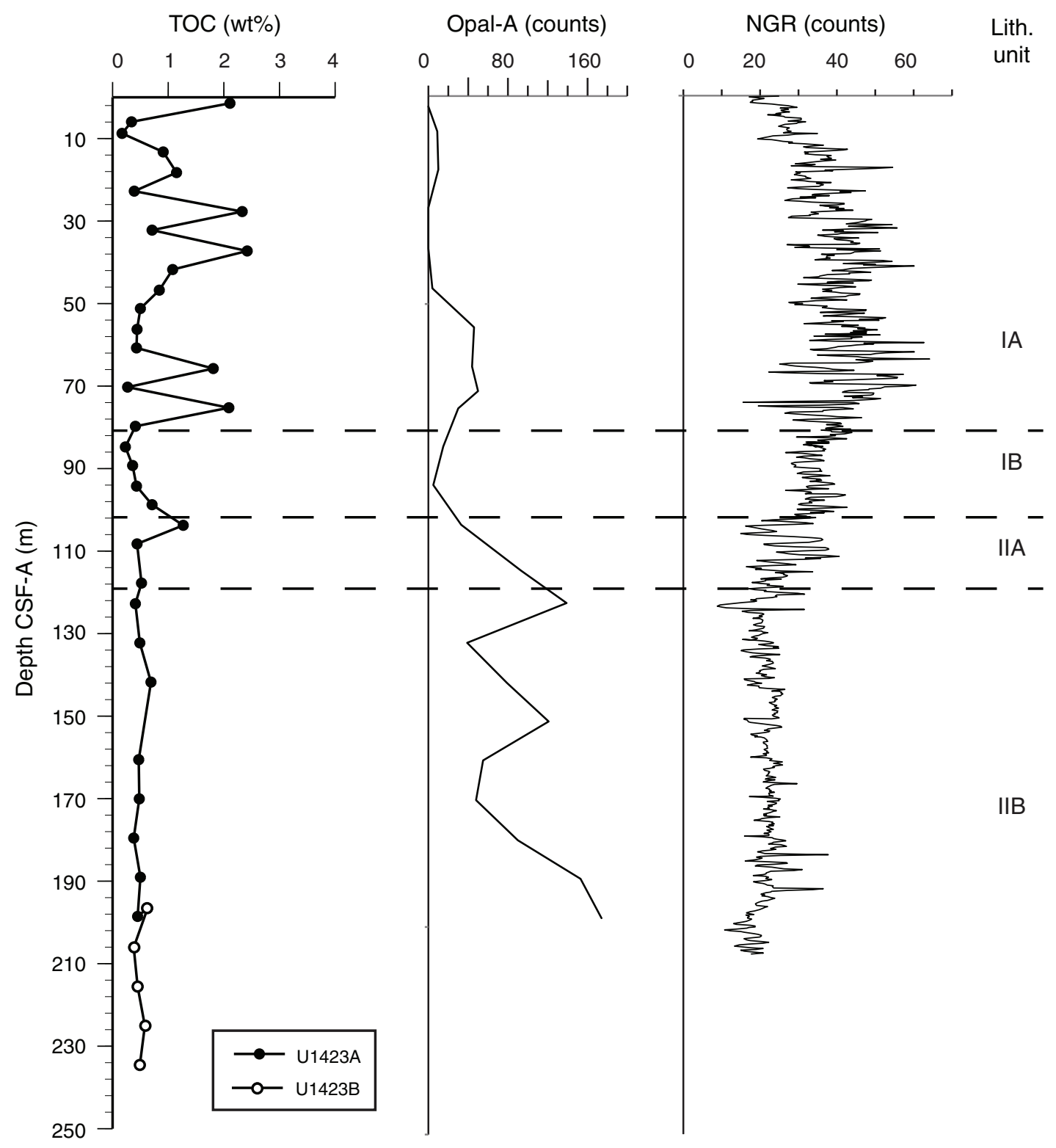


Figure F15. Integrated calcareous and siliceous microfossil biozonation, Site U1423.

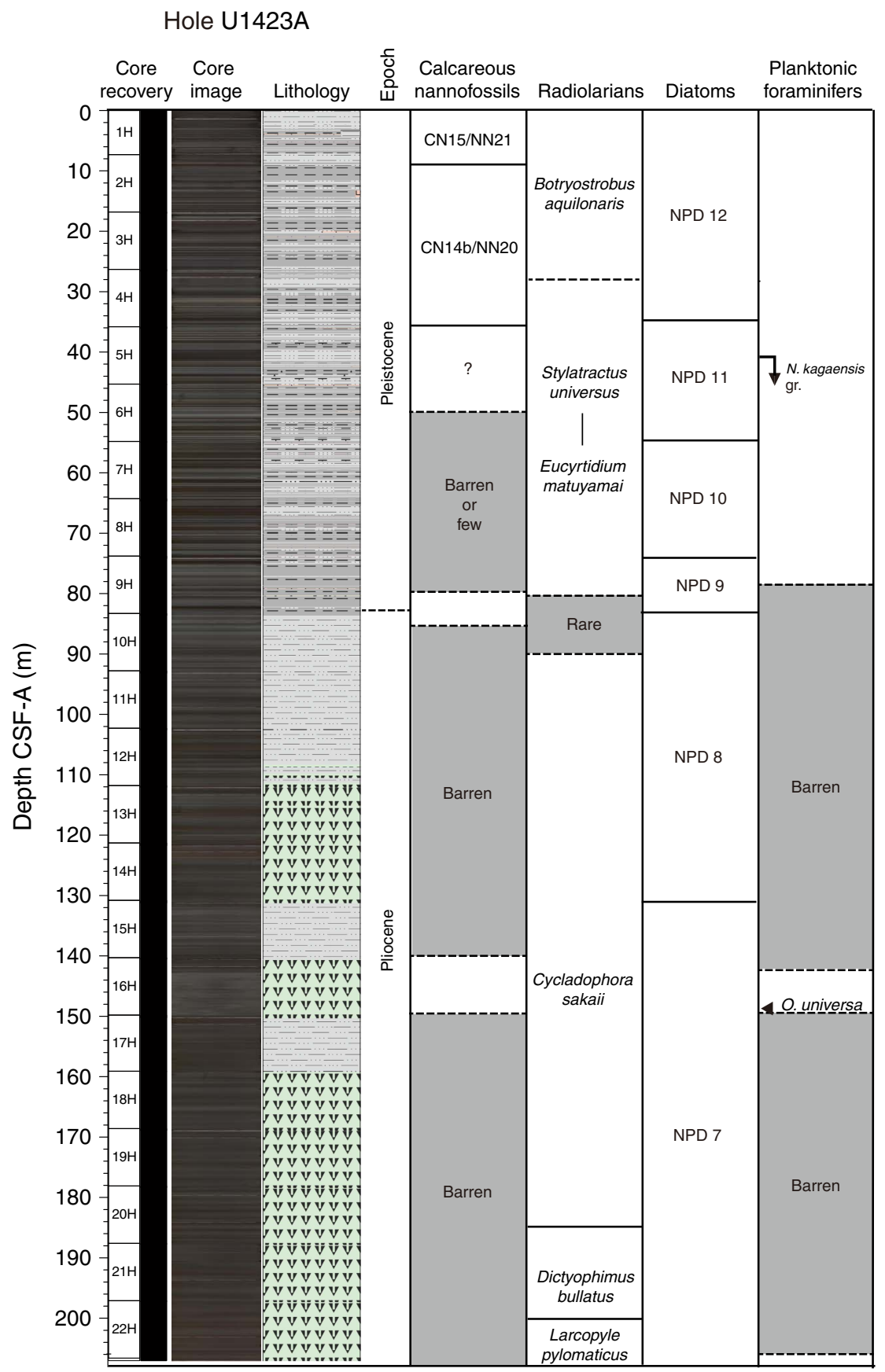


Figure F16. Preliminary age-depth profile and estimated sedimentation rates, Site U1423. LO = last occurrence, $\mathrm{FO}=$ first occurrence, $\mathrm{RD}=$ rapid decrease, $\mathrm{Br}=$ base reentrance.
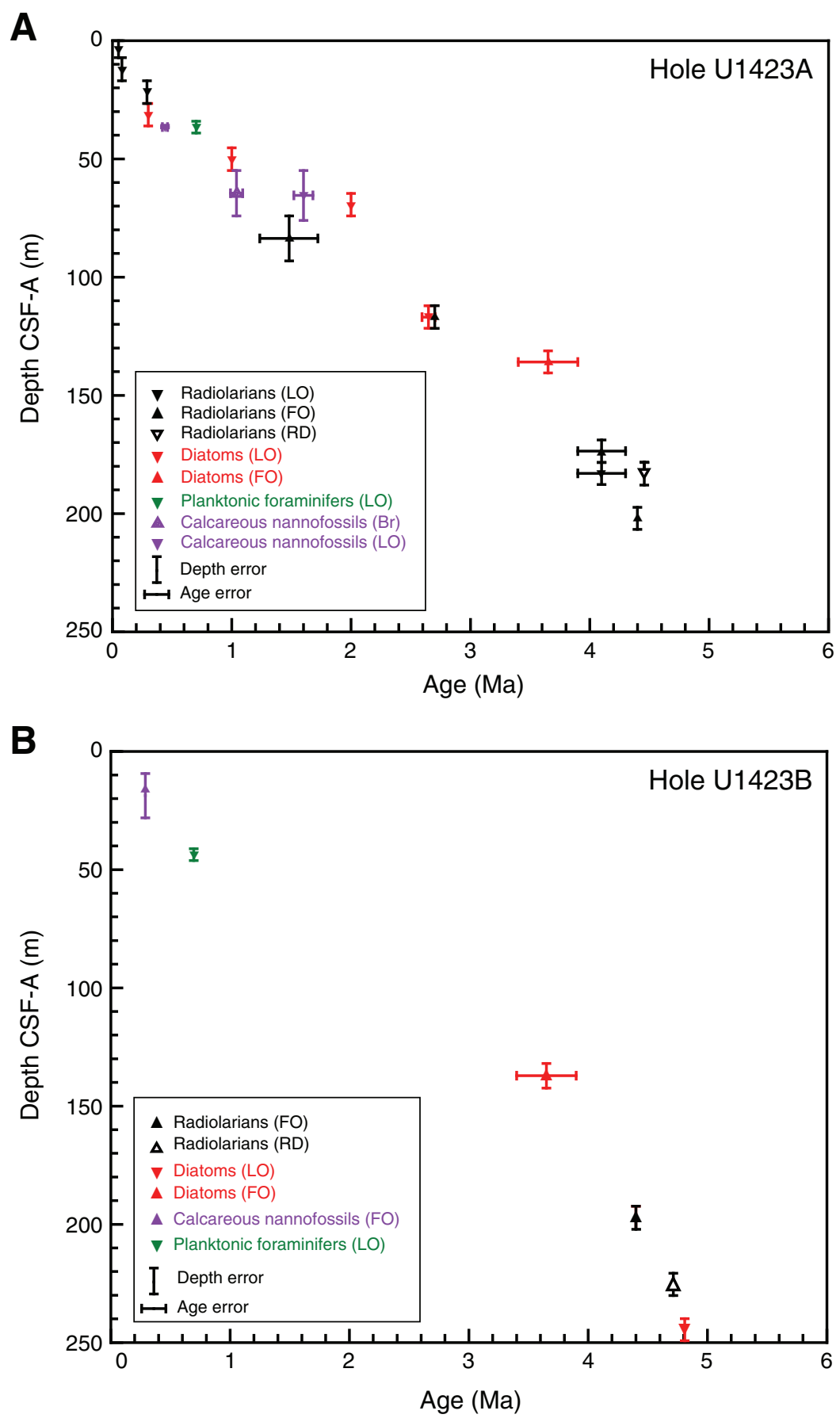


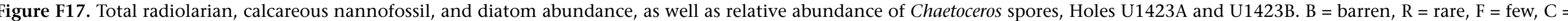
common, $\mathrm{A}=$ abundant, $\mathrm{D}=$ dominant.
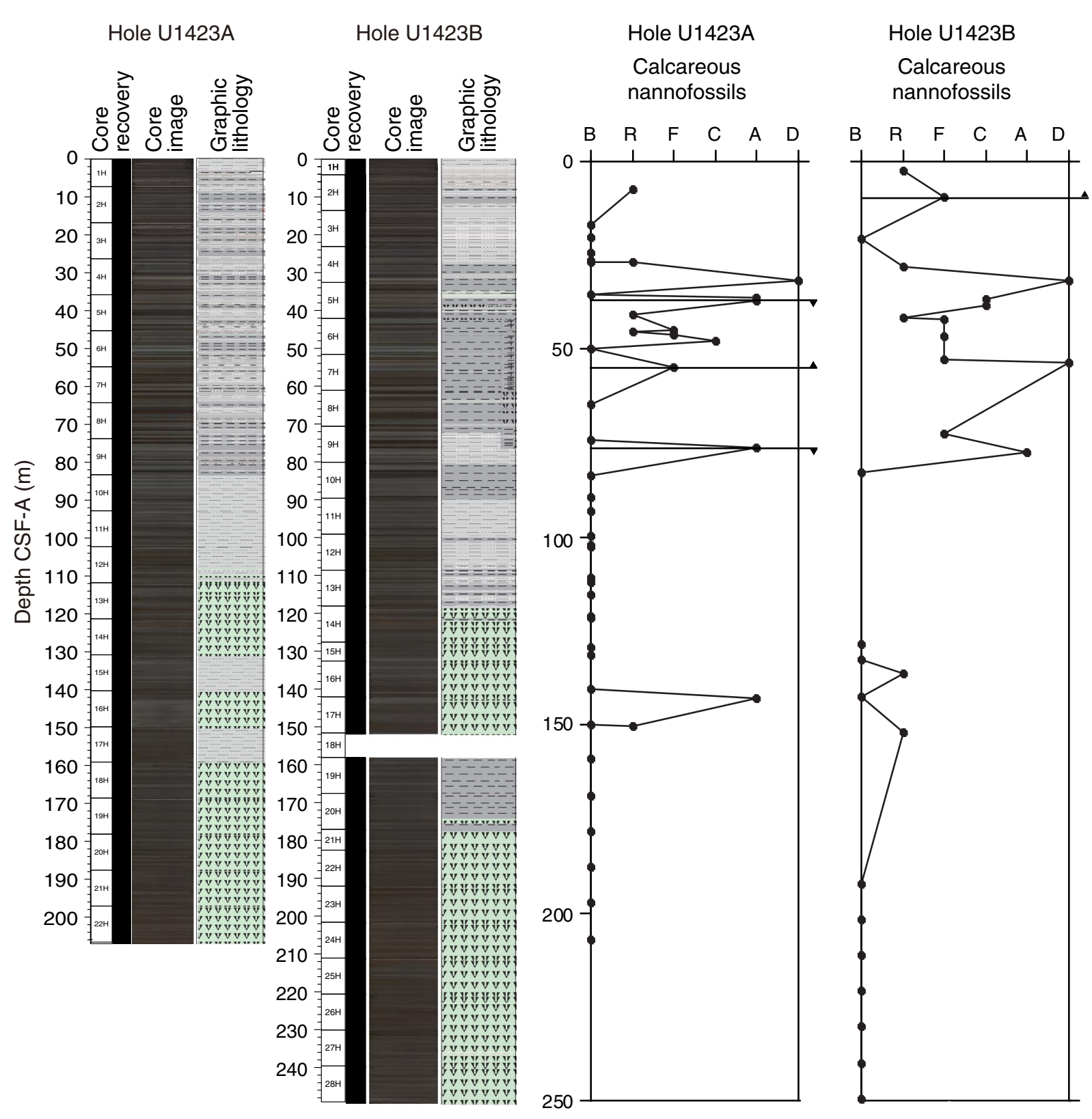

Radiolarians

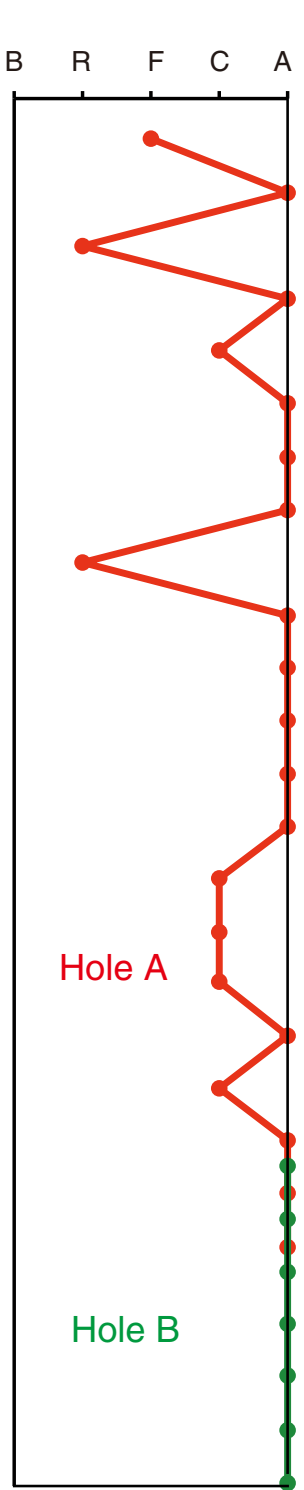

Hole U1423A

Qualitative Qualitative productivity indicators diatom abundance (\%) Chaetoceros spore

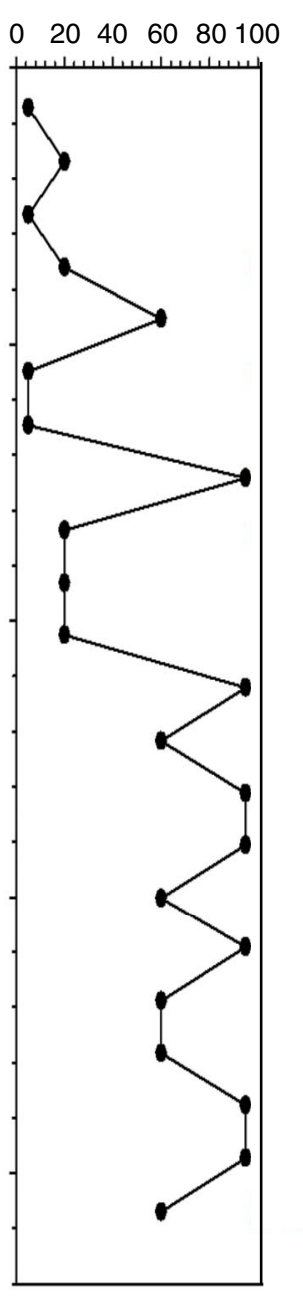
abundance (\%) 
Figure F18. Percentage abundance of planktonic (blue) and benthic (yellow) foraminifers and barren intervals (black), Site U1423. Orange arrows mark horizons with diverse (oxic) benthic assemblages, green arrows mark horizons with abundant Bolivina pacifica (dysoxia).
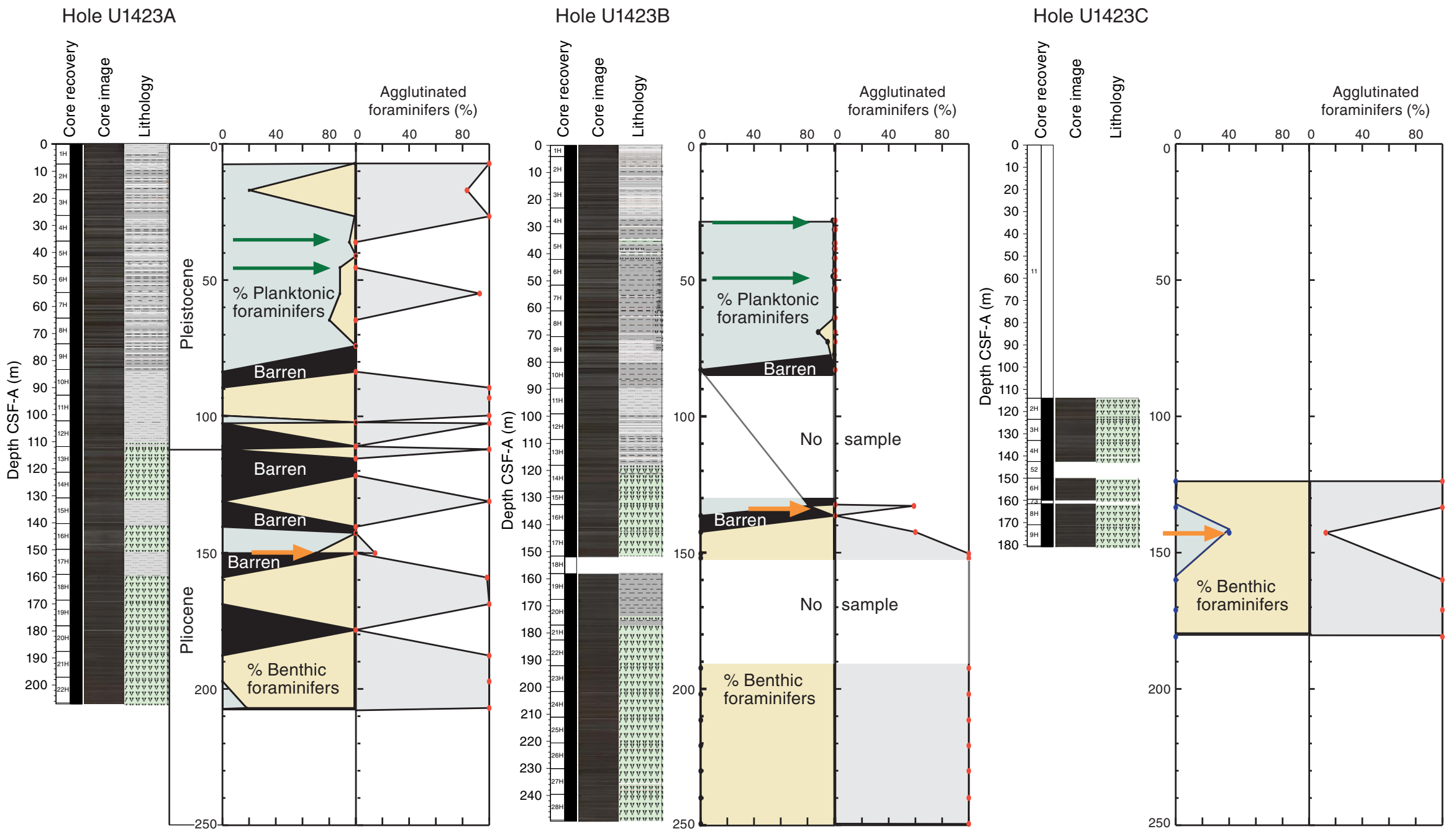
Figure F19. Benthic foraminifers from diverse assemblages indicative of more oxic conditions at the seafloor. Scale bars $=50 \mu \mathrm{m}$. 1. Lenticulina sp. (Sample 346-U1423A-16H-CC). 2, 3. Bulimina mexicana (Sample 346U1423A-16H-CC). 4. Hoeglundina elegans (Sample 346-U1423A-16H-CC). 5. Martinotiella communis (Sample 346-U1423B-15H-CC). 6, 7. Oridorsalis umbonatus (Sample 346-U1423A-16H-CC); (6) spiral view; (7) umbilical view. 8, 9. Melonis pompilioides (Sample 346-U1423A-16H-CC); (8) umbilical view (9) side view. 10. Melonis barleeanum (side view) (Sample 346-U1423A-16H-CC). 11. Karreriella sp. (Sample 346-U1423A-16H-CC). 12. Eggerella bradyi (umbilical view) (Sample 346-U1423A-16H-CC). 13. Globobulimina pupoides (Sample 346U1423A-16H-CC). 14. Globobulimina pacifica (Sample 346-U1423A-16H-CC). 15. Pyrgo murrhina (umbilical view) (Sample 346-U1423B-15H-CC). 16. Gyroidina orbicularis (Sample 346-U1423A-16H-CC). 17. Gyroidella sp. (Sample 346-U1423A-16H-CC). 18, 19. Bolivina quadrilatera; (18) umbilical view (Sample 346-U1423B-15HCC); (19) Sample 346-U1423A-16H-CC.

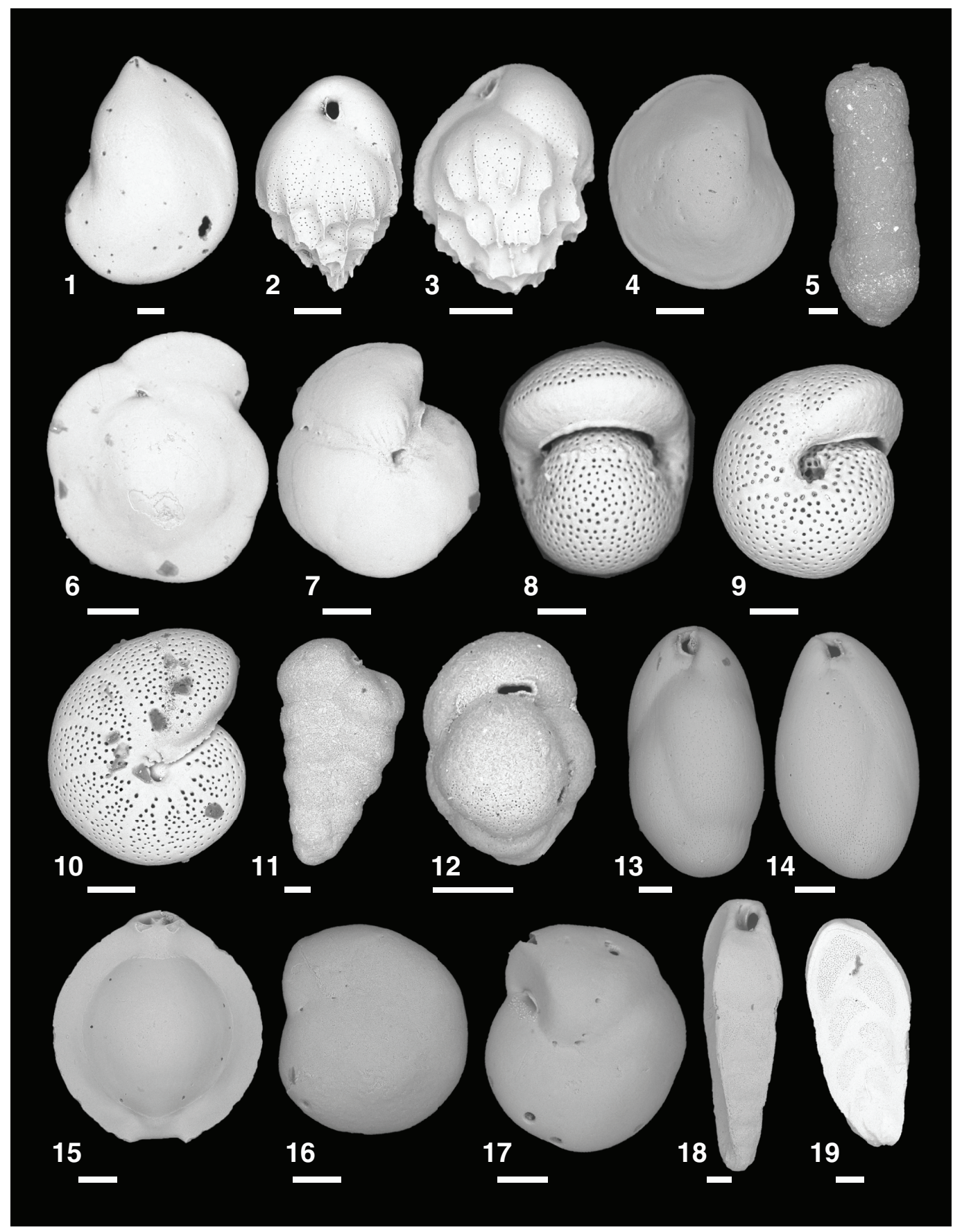


Figure F20. Organically cemented agglutinated foraminifers from Hole U1423A mudline sample. Scale bars = $50 \mu \mathrm{m} .1$, 2, 5. Haplophragmoides sphaeriloculum. 3, 4. Paratrochammina challengeri (spiral view) with detail of wall structure. 6, 7. Cribrostomoides subglobosus with detail of aperture. 8-10. Miliammina echigoensis; (9) stained specimen, which exhibits much better preservation than unstained specimens (8) and (10). 11, 12. Jacullela cf. acuta with detail of wall structure. 13, 14. Hyperammina elongata with detail of initial portion. 15, 16. Rhabdammina sp. with detail of wall structure. 17. Paratrochammina challengeri (umbilical view). 18. Haplophragmoides sphaeriloculum. 19. Cribrostomoides subglobosus.

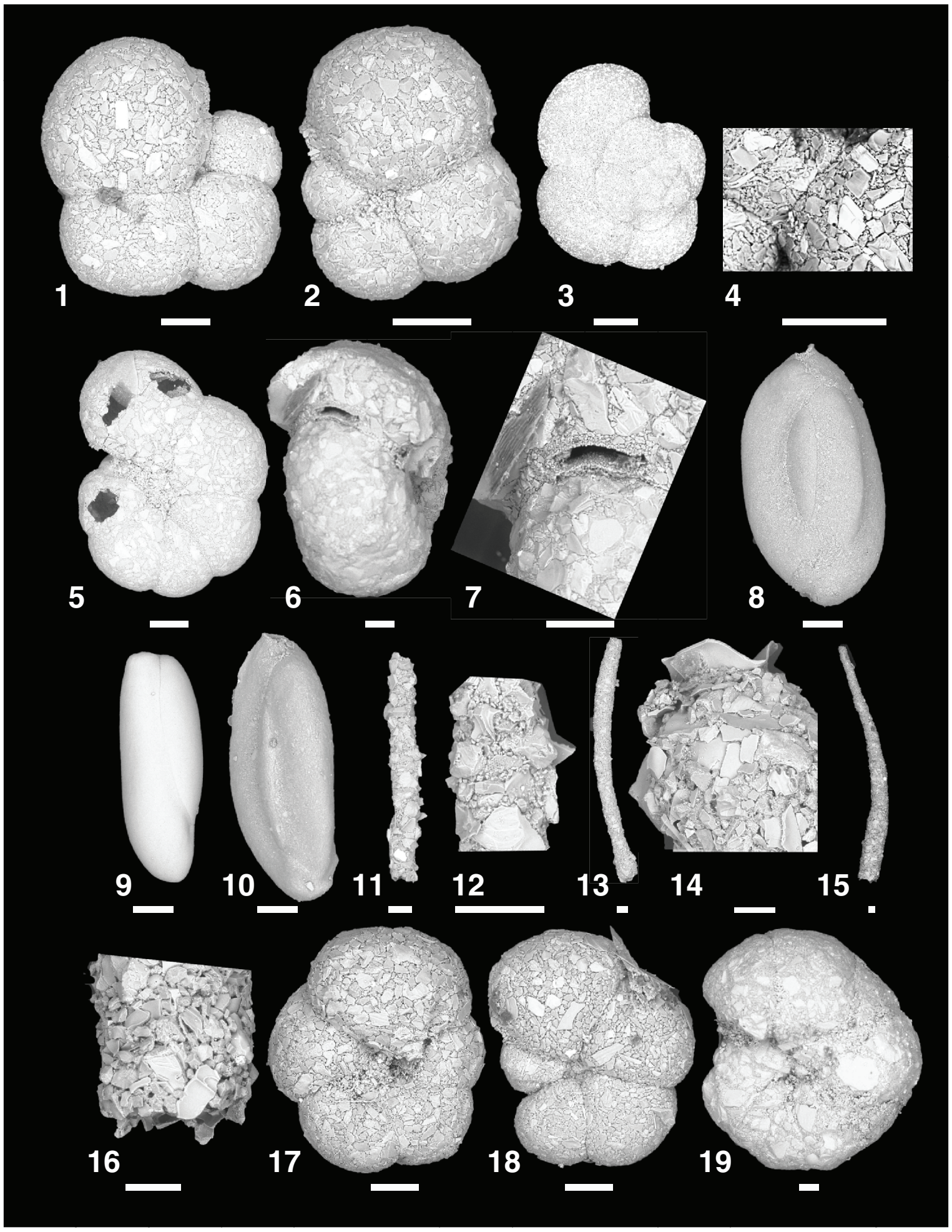


Figure F21. Ostracods (Sample 346-U1423A-16H-CC). A, B. Henryhowella cf. H. circumdentata (Brady, 1880). C. Krithe sp. 1. D, E. Krithe sp. 2; (E) detail of a sieve pore. F. Legitimocythere sp.

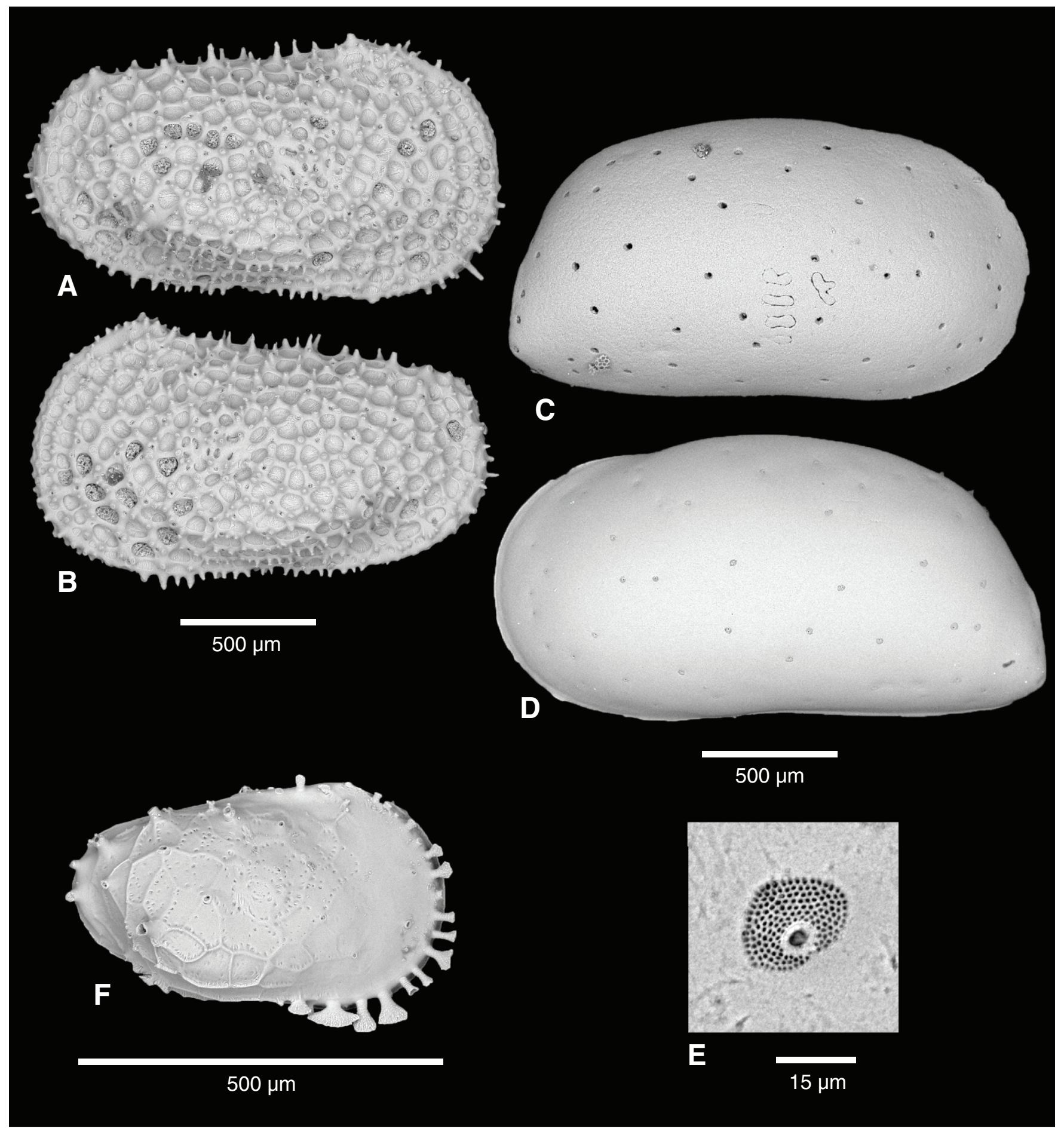


Figure F22. Solid-phase contents of discrete sediment samples, Site U1423. TC = total carbon, TOC = total organic carbon, $\mathrm{TN}=$ total nitrogen.

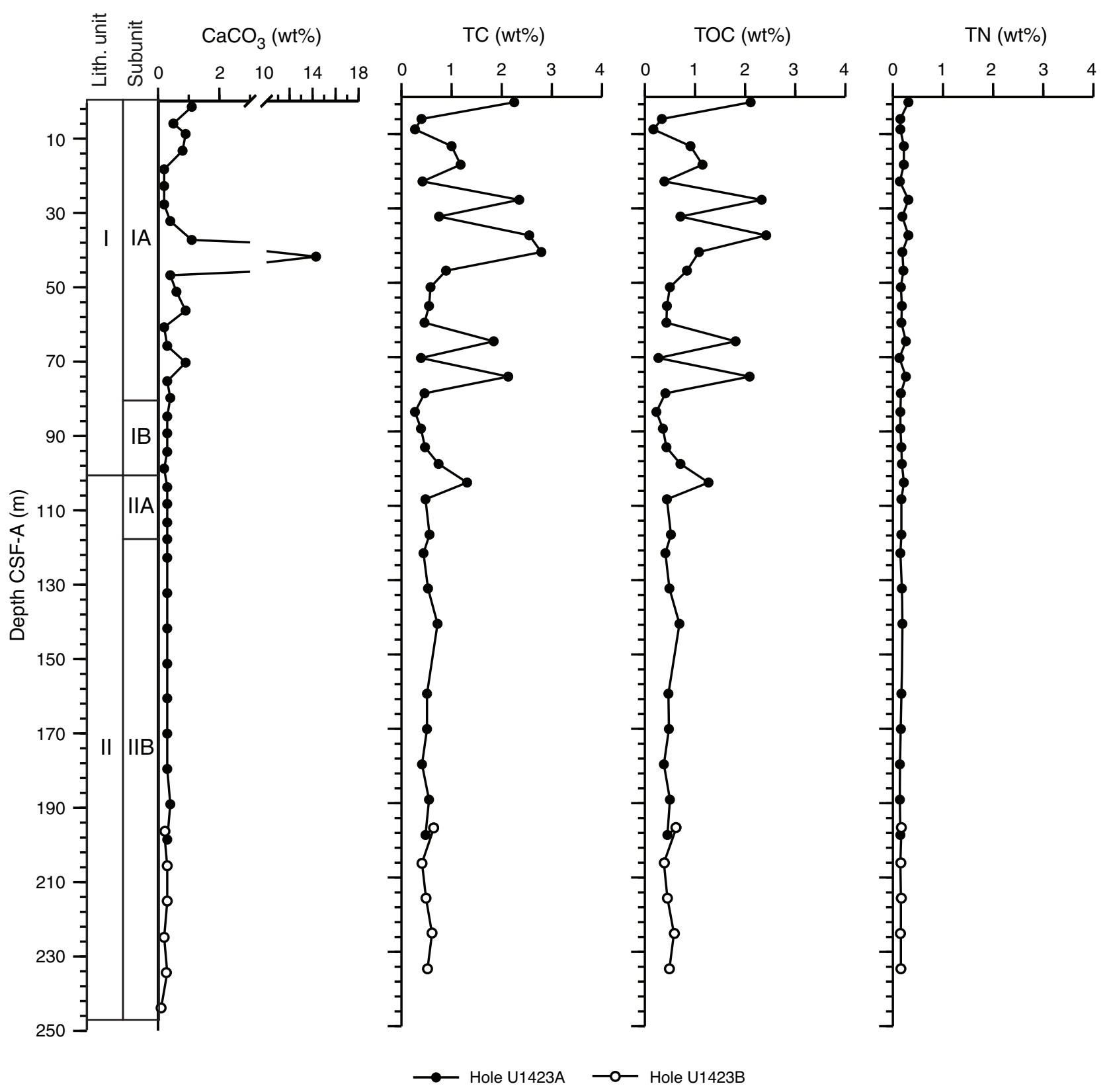


Figure F23. Dissolved iron and manganese profiles, Site U1423.

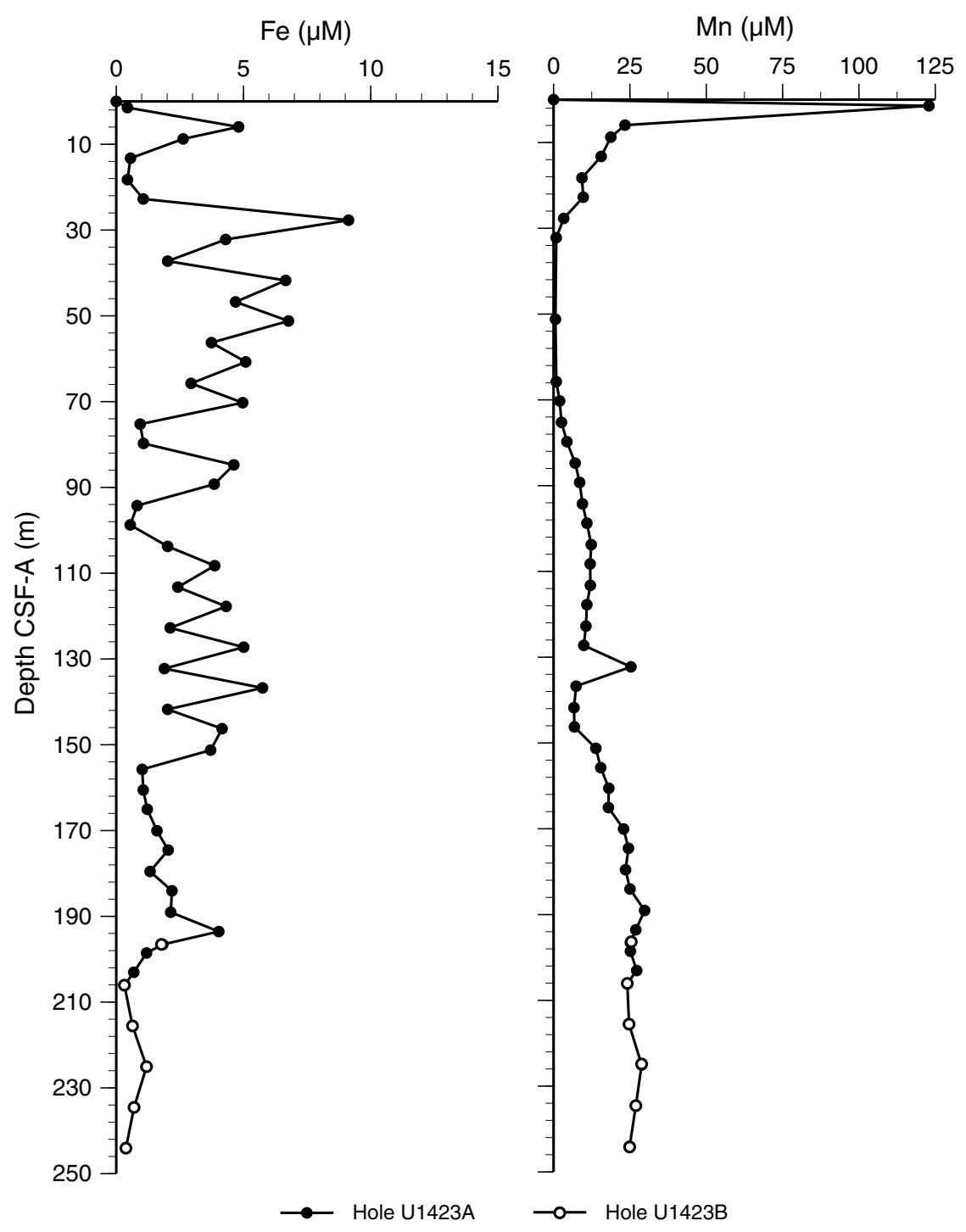


Figure F24. Dissolved alkalinity, ammonium, and phosphate profiles, Site U1423.

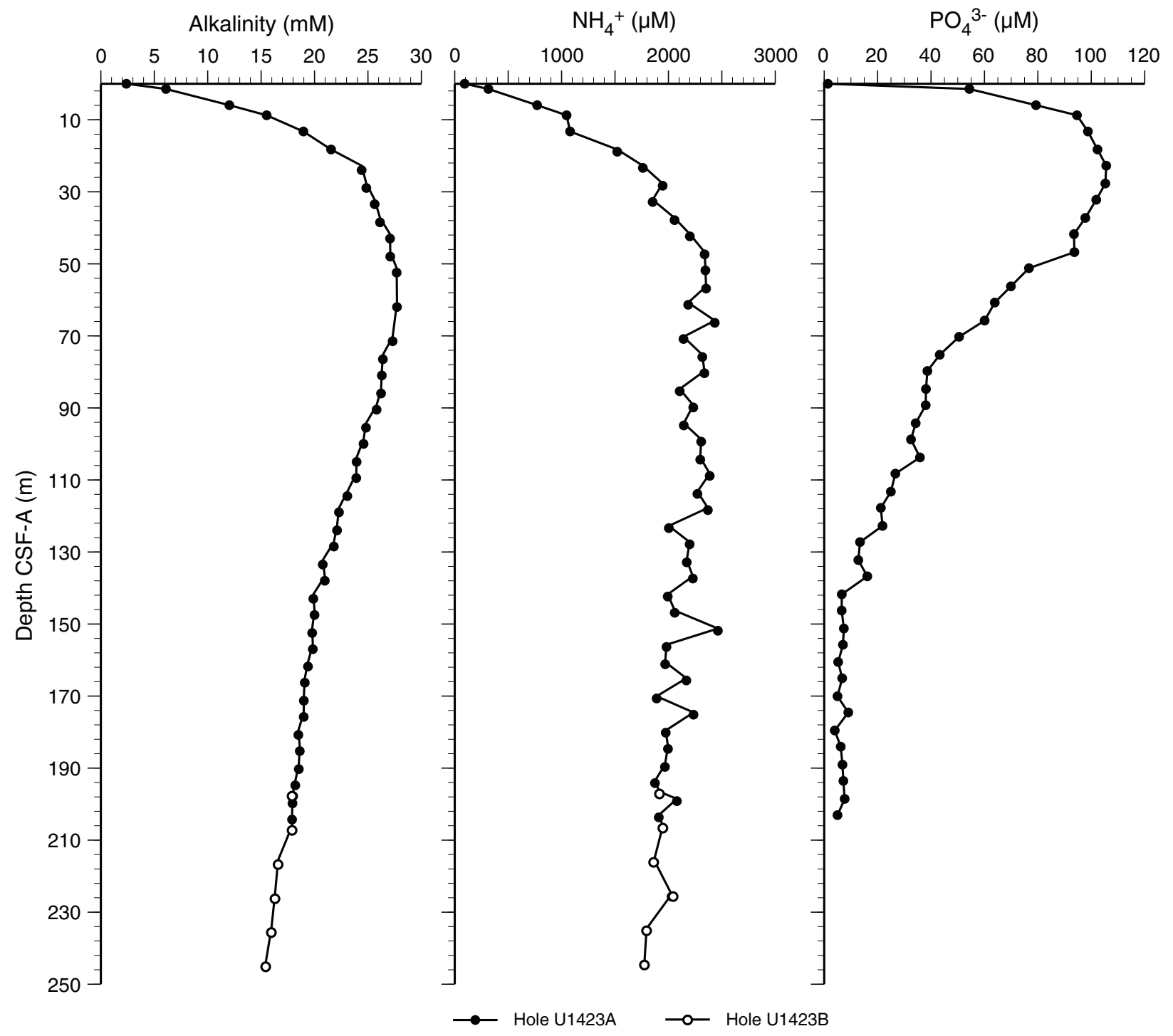


Figure F25. Headspace $\mathrm{CH}_{4}$ concentrations with depth at Site U1423 with Site U1422 for comparison. Note that values are not meaningful at depths where $\mathrm{CH}_{4}$ surpasses saturation at 1 atm pressure ( 40 m CSF-A).

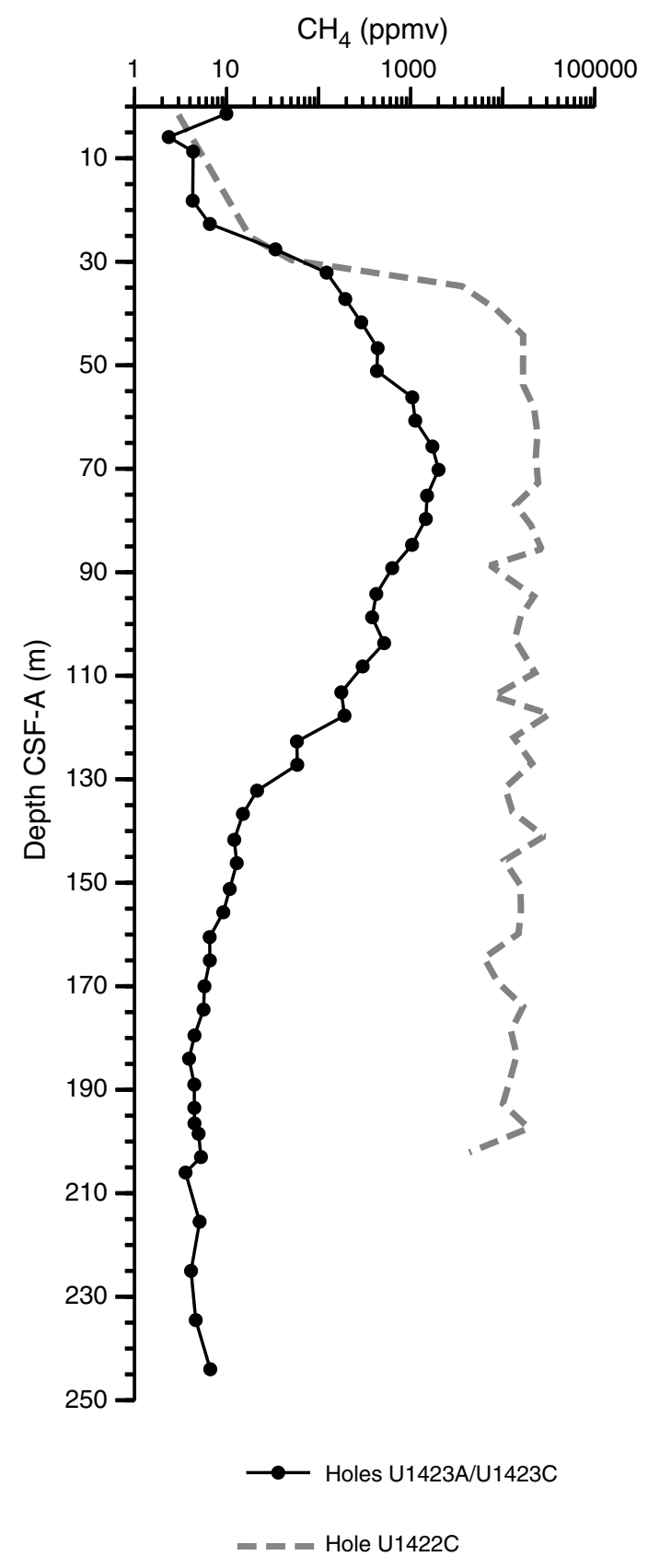


Figure F26. Headspace $\mathrm{CH}_{4}$ and dissolved $\mathrm{SO}_{4}{ }^{2-}$ concentrations with depth, Site U1423.

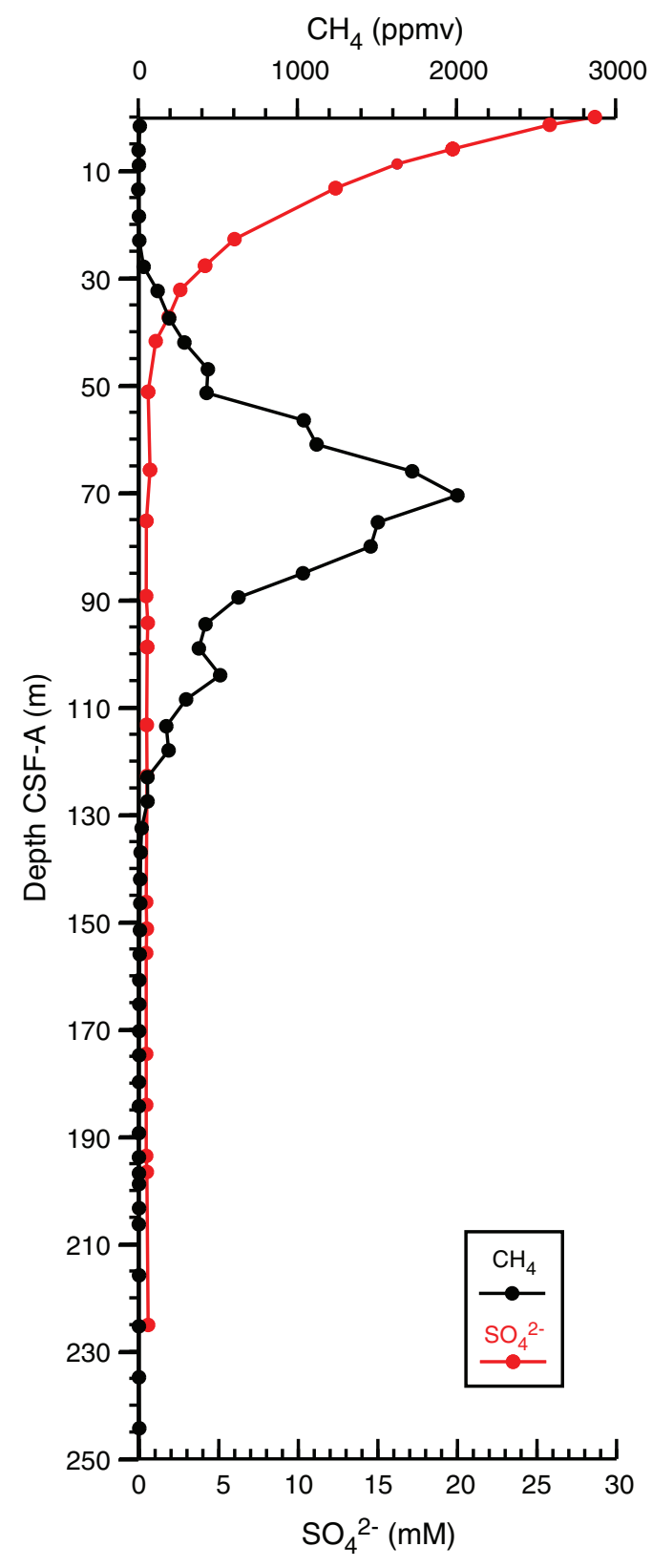


Figure F27. Dissolved $\mathrm{SO}_{4}{ }^{2-}$ and barium profiles, Site U1423.

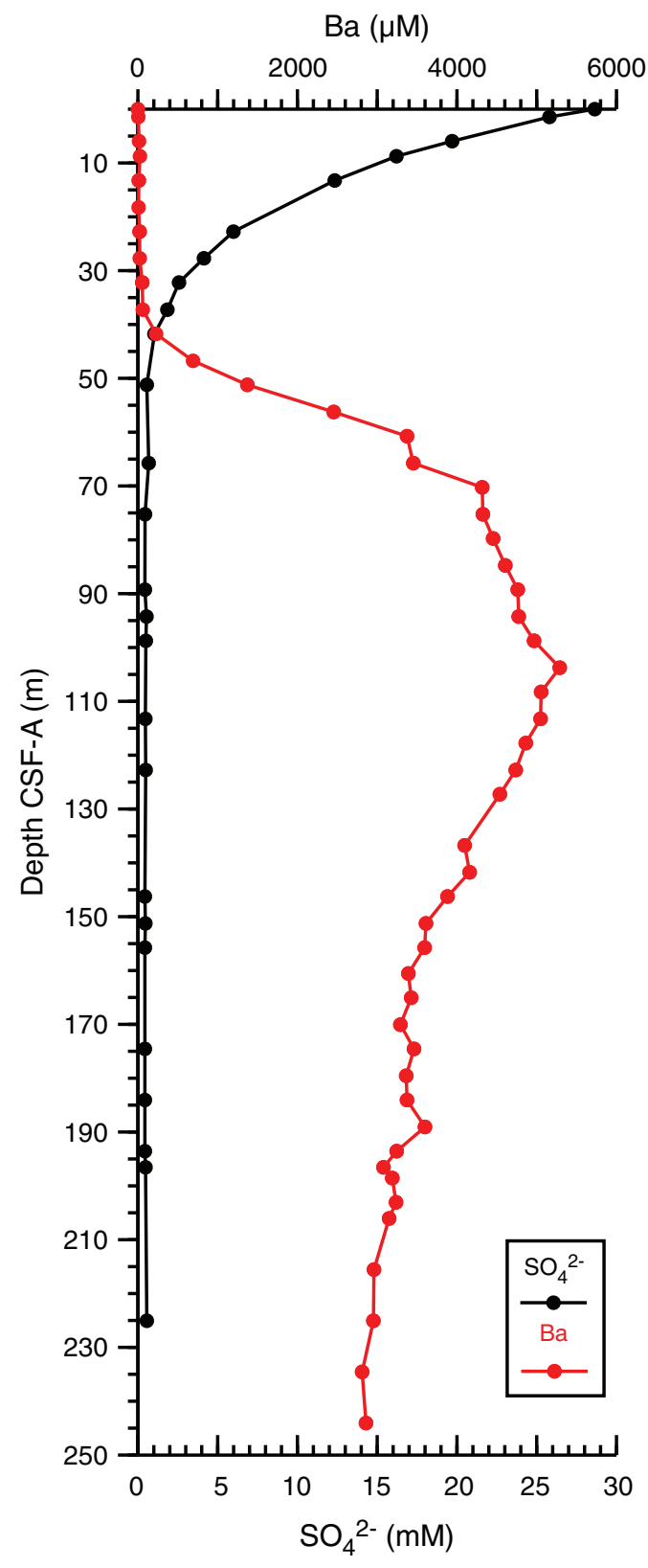


Figure F28. Dissolved calcium, magnesium, and strontium profiles, Site U1423.

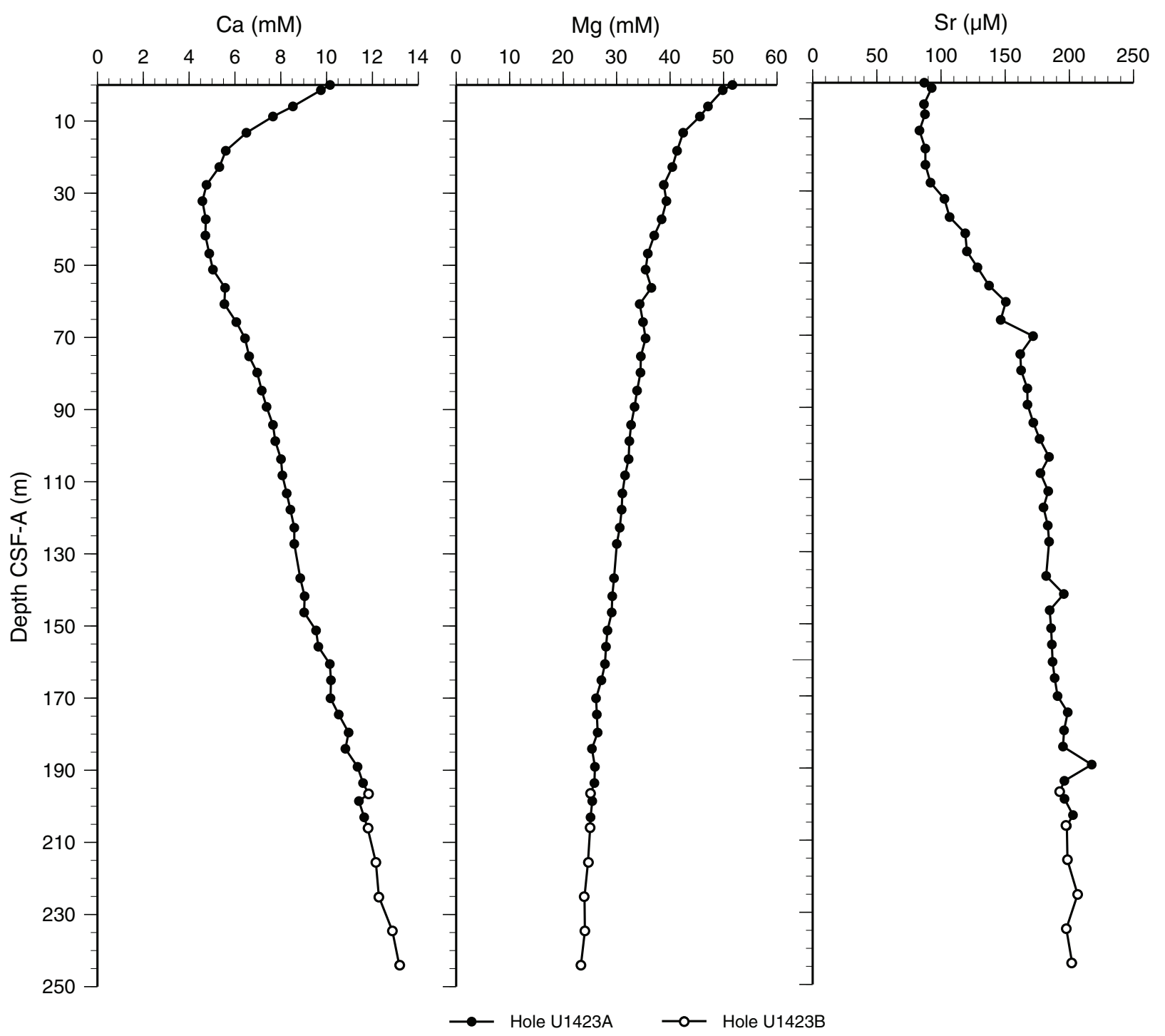


Figure F29. Dissolved $\mathrm{Cl}^{-}, \mathrm{Na}$, and K profiles, Site U1423.

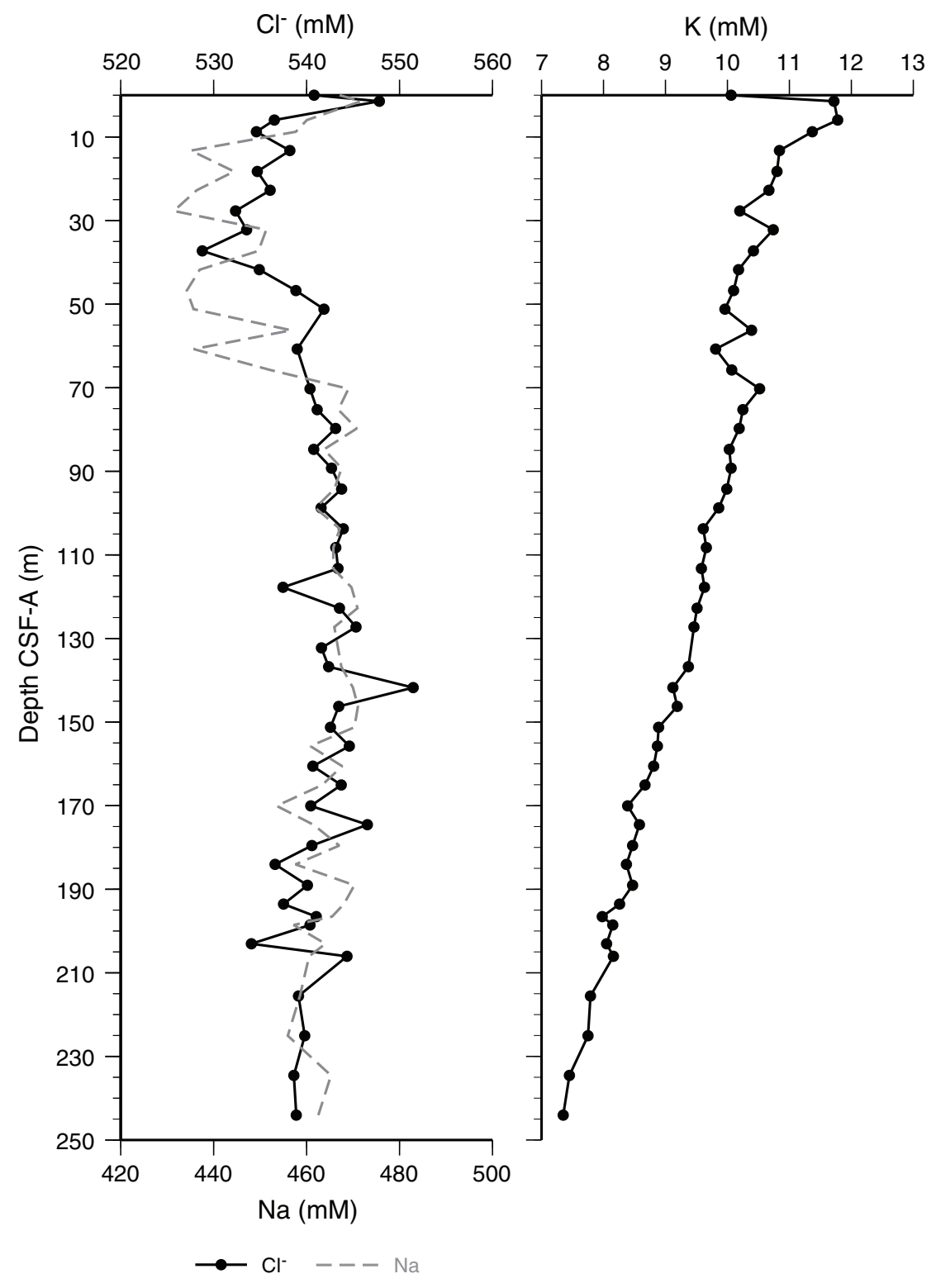


Figure F30. Dissolved B, Li, and silica concentrations with depth, Site U1423. The silica values determined by spectrophotometer (spec) agree favorably with the values determined on the inductively coupled plasma (ICP) -atomic emission spectroscopy. Solid circles indicate samples from Hole U1423A and open circles indicate samples from Hole U1423B.

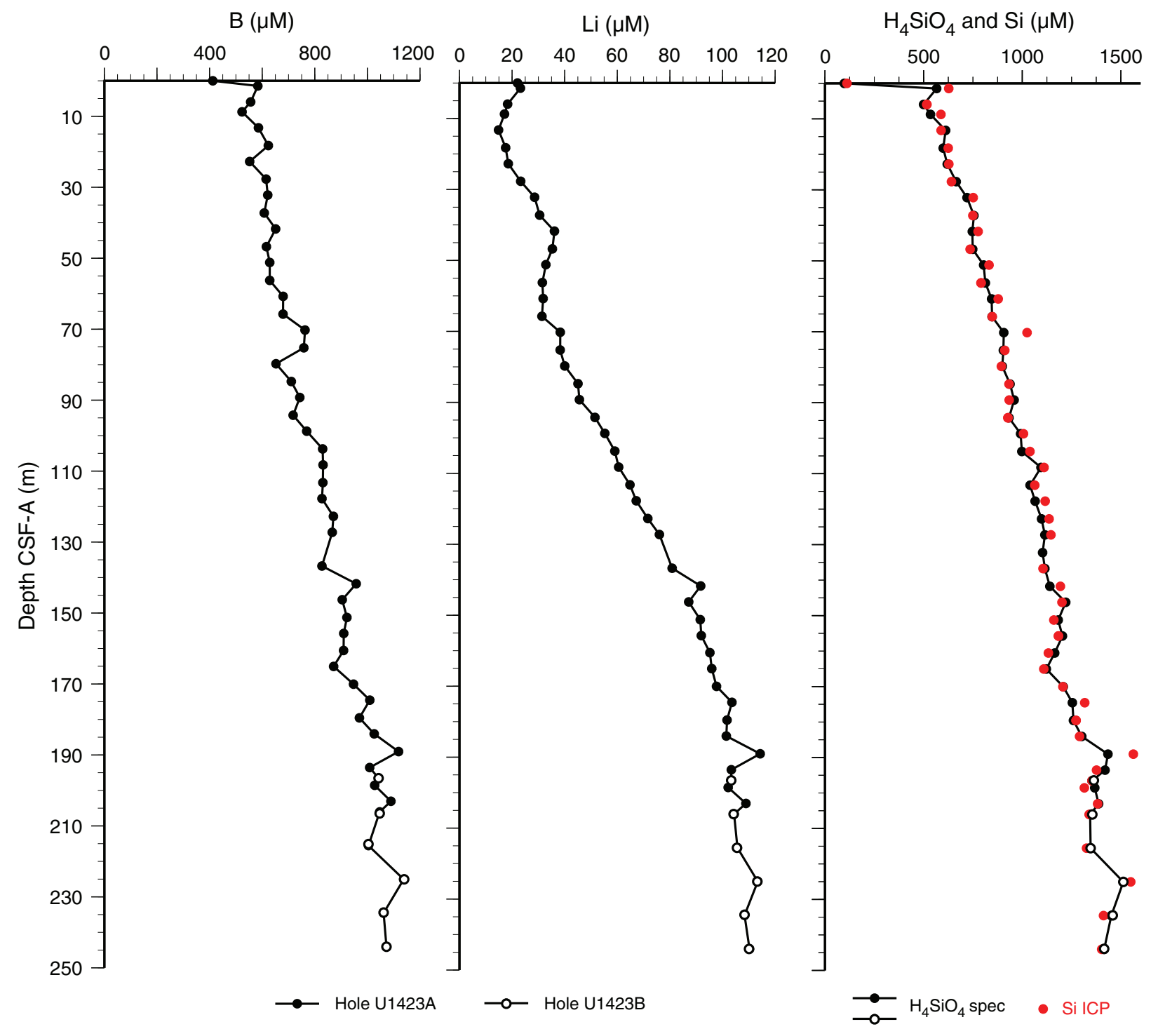


Figure F31. Paleomagnetism after $20 \mathrm{mT}$ AF demagnetization, Site U1423. Chron column: black = normal polarity, white = reversed polarity, gray $=$ zones or polarity boundaries without clear magnetostratigraphic interpretation. Inclination column: thin black dashed lines $=$ expected geocentric axial dipole) inclinations at the site latitude during reversed (left) and normal (right) polarities, triangles along the left side mark depths where discrete paleomagnetic cube samples were collected (orange = discrete samples measured during the expedition). Declination column: gray dots $=$ measured declination values, green dots $=$ declination values corrected using core orientation data collected by the FlexIT tool. Susceptibility column: SHMSL and WRMSL measured values are shown in magenta and gray dots, respectively. A. Hole U1423A. (Continued on next two pages.)

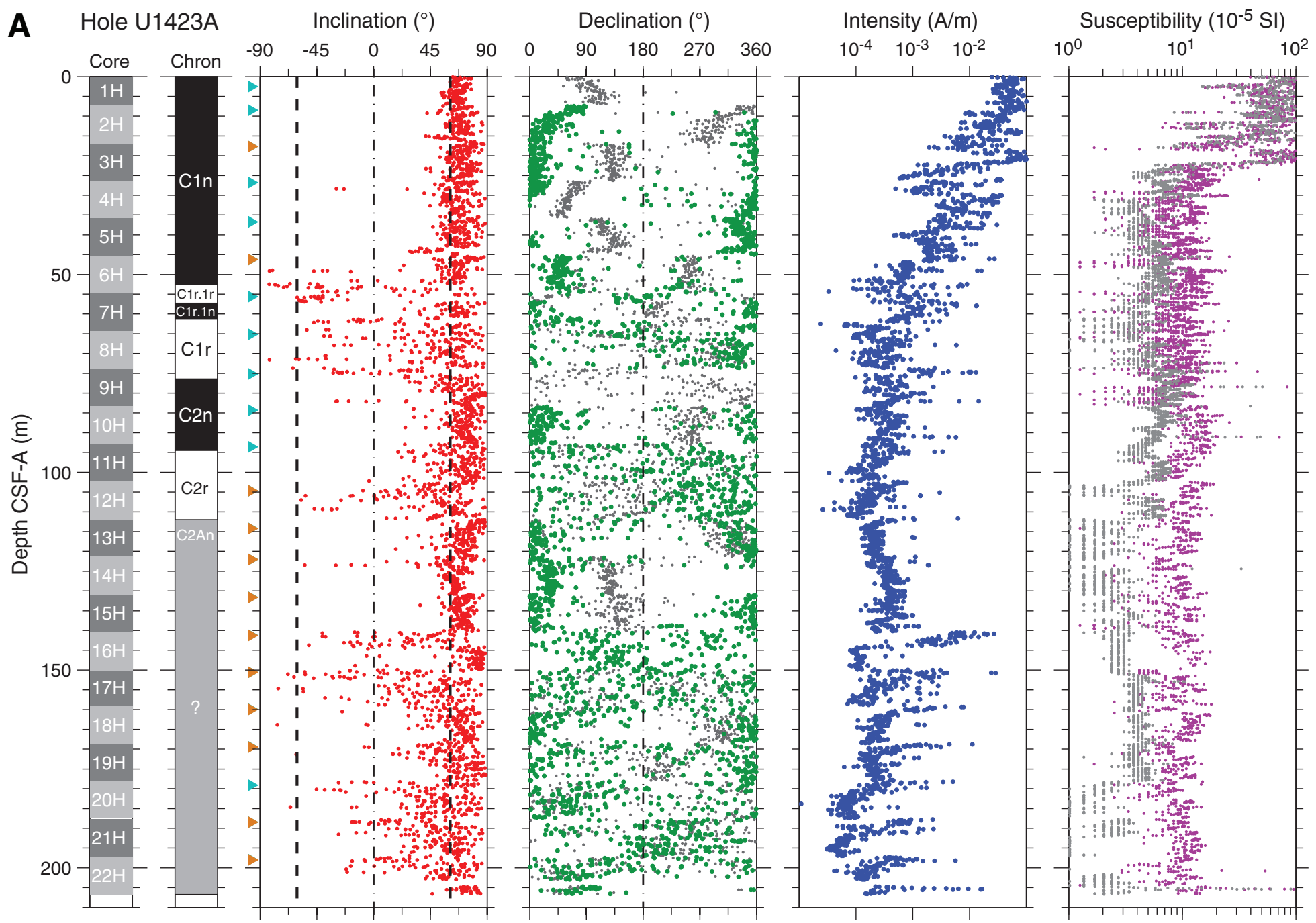


Figure F31 (continued). B. Hole U1423B. (Continued on next page.)

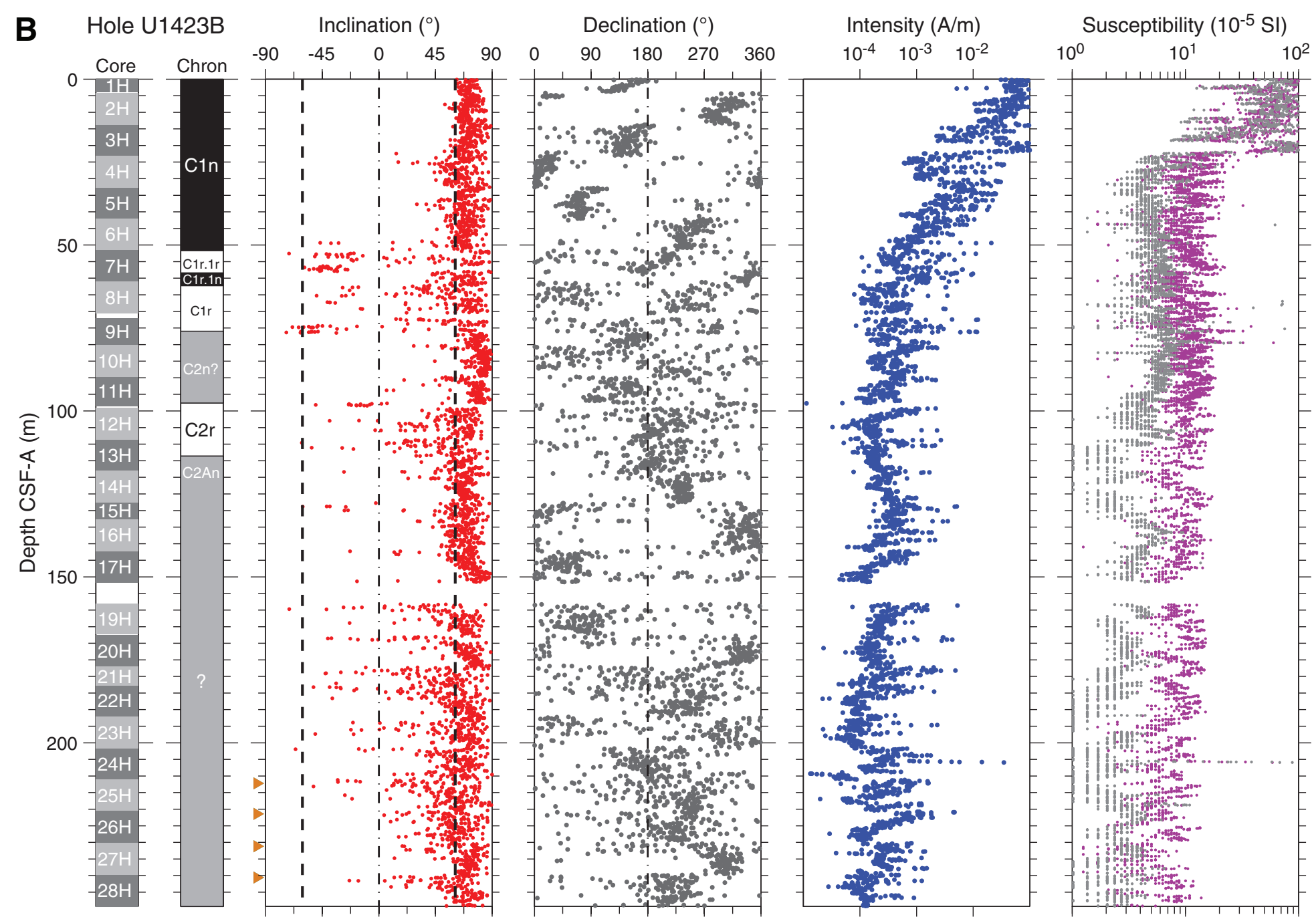




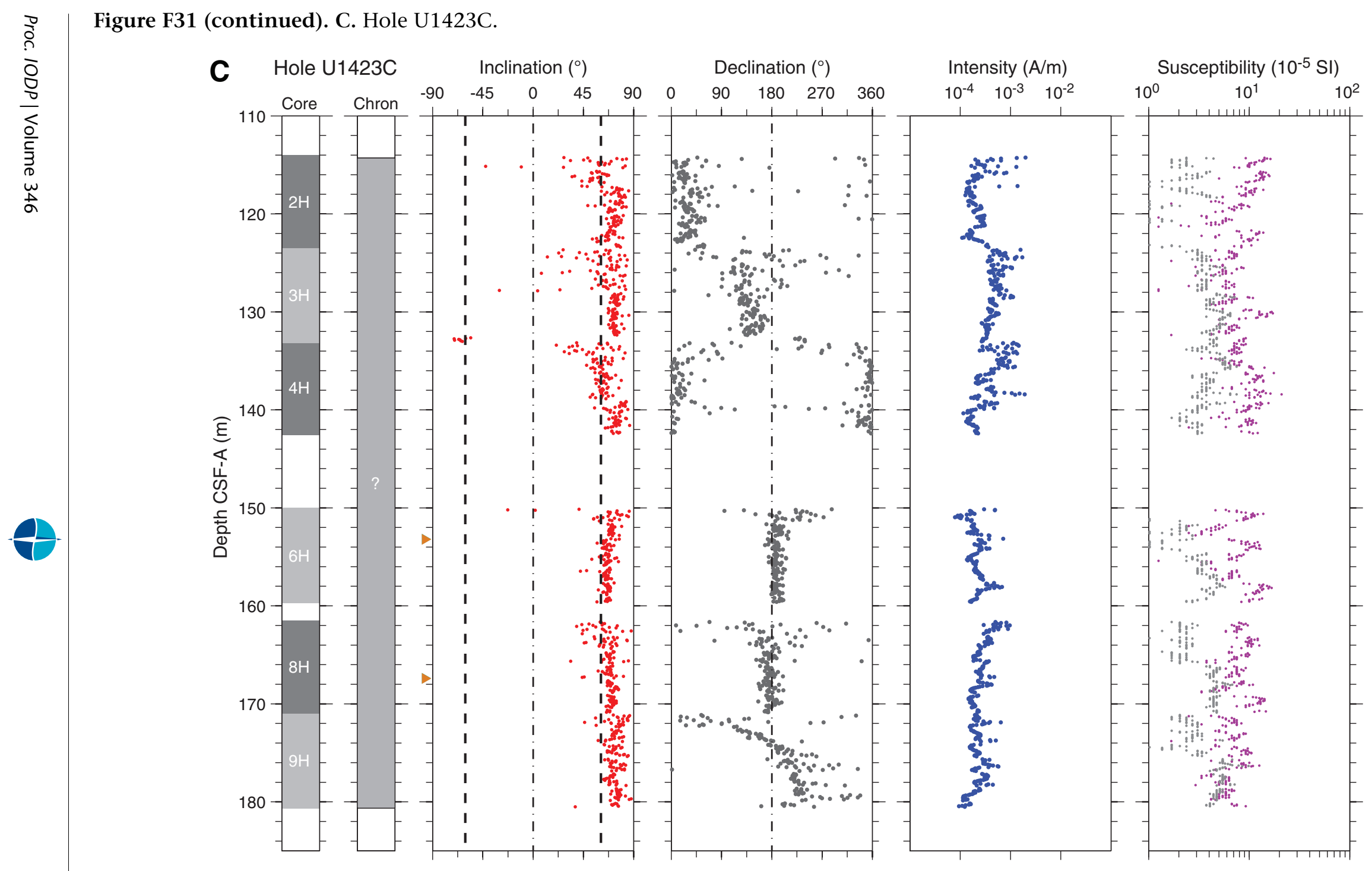


Figure F32. A-H. AF demagnetization results for eight discrete samples, Site U1423. For each sample, the left plot shows the intensity variation with progressive demagnetization. The middle and right plots show the NRM vector measured after each demagnetization treatment on an orthogonal projection (Zijderveld) and on an equal area projection, respectively. In the orthogonal projection plot, squares $=$ horizontal projections, circles $=$ vertical projections. In the equal area projection plot, solid circles $=$ projection data with positive inclinations, open circles $=$ projection data with negative inclinations. Note that on the orthogonal projection (Zijderveld) plot, NRM data before demagnetization have been removed to better display the demagnetized data.

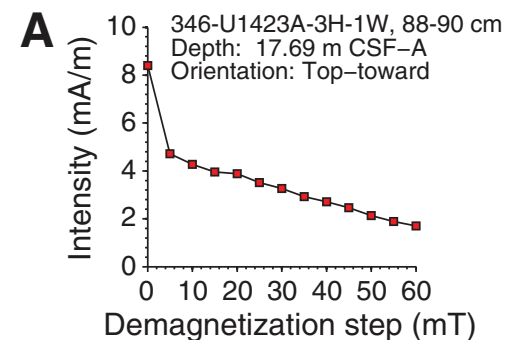

B ${ }^{4}$ 346-U1423A-6H-1W, 96-98 cm

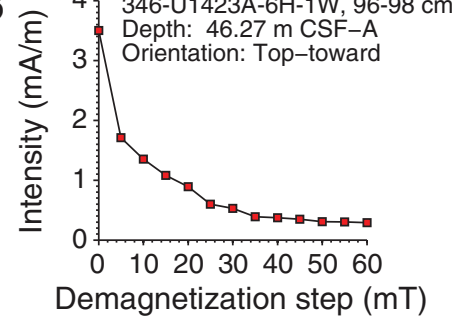

C ${ }^{2}$ 年 $\begin{aligned} & \text { 346-U1423A-12H-2W, } 91-93 \mathrm{~cm} \\ & \text { Depth: } 104.72 \mathrm{~m} \mathrm{CSF}-\mathrm{A}\end{aligned}$

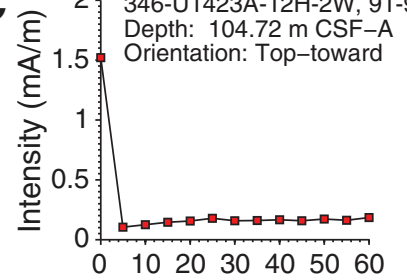

Demagnetization step (mT)

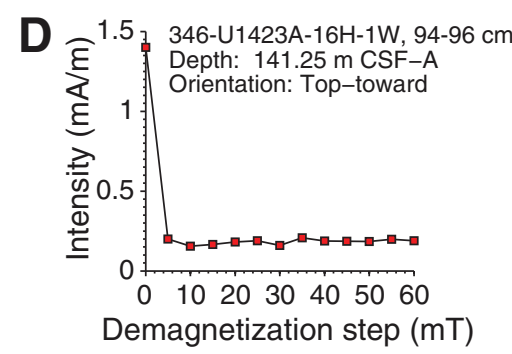

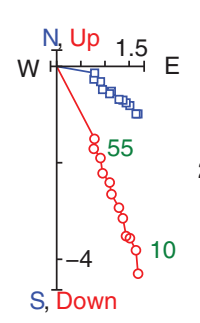
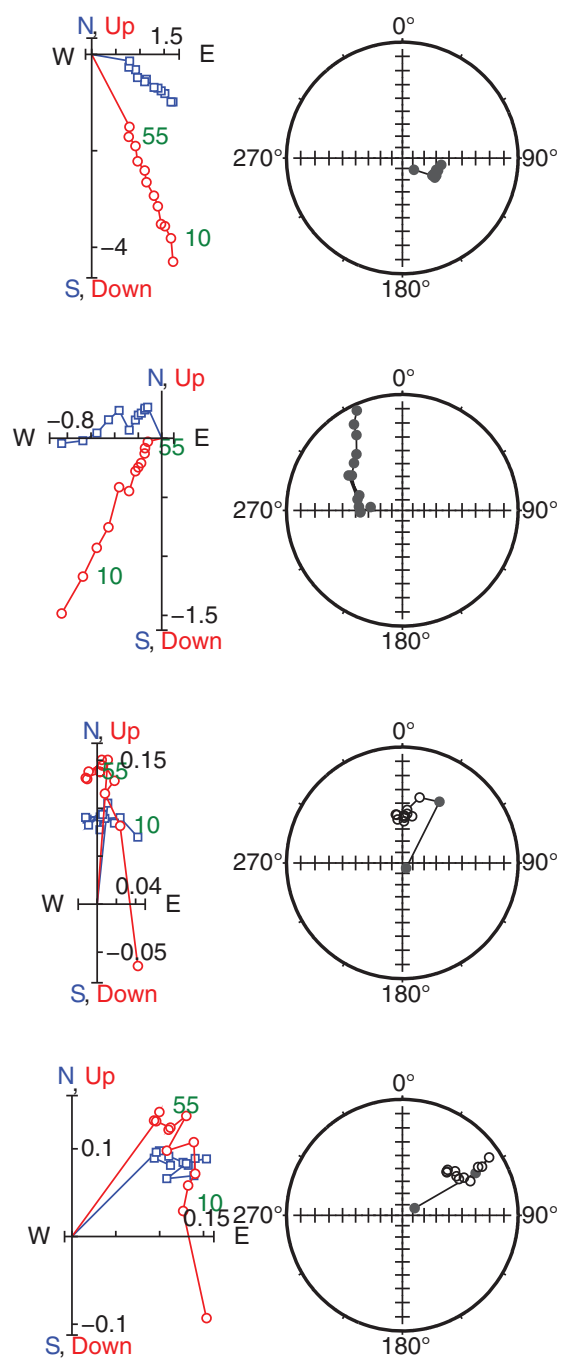

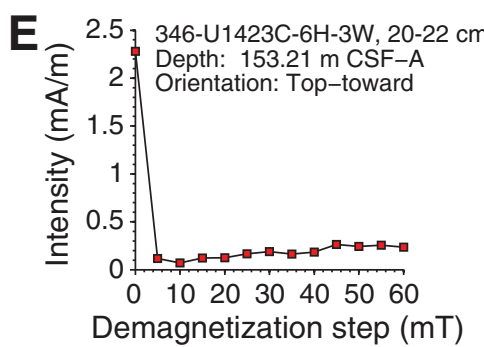

F 2 , 346-U1423A-19H-1W, $86-88 \mathrm{~cm}$

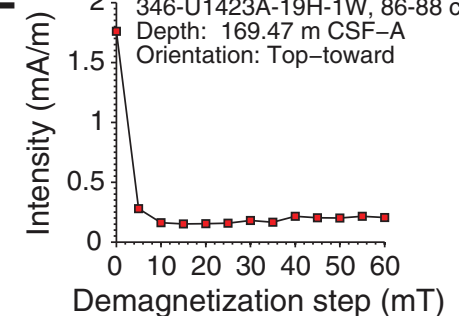

G 0.5 346-U1423A-22H-1W, $85-87 \mathrm{~cm}$

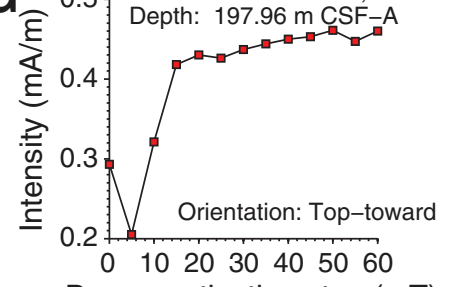

Demagnetization step $(\mathrm{mT})$

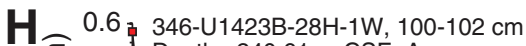

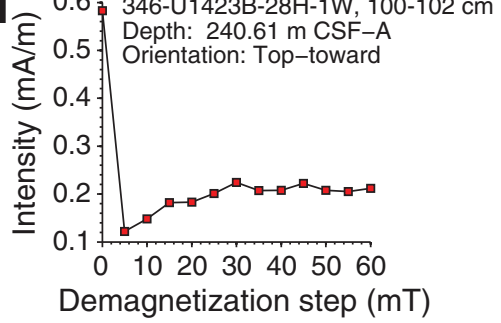

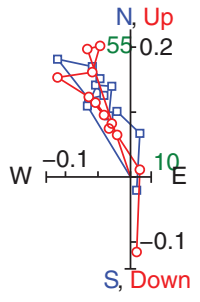
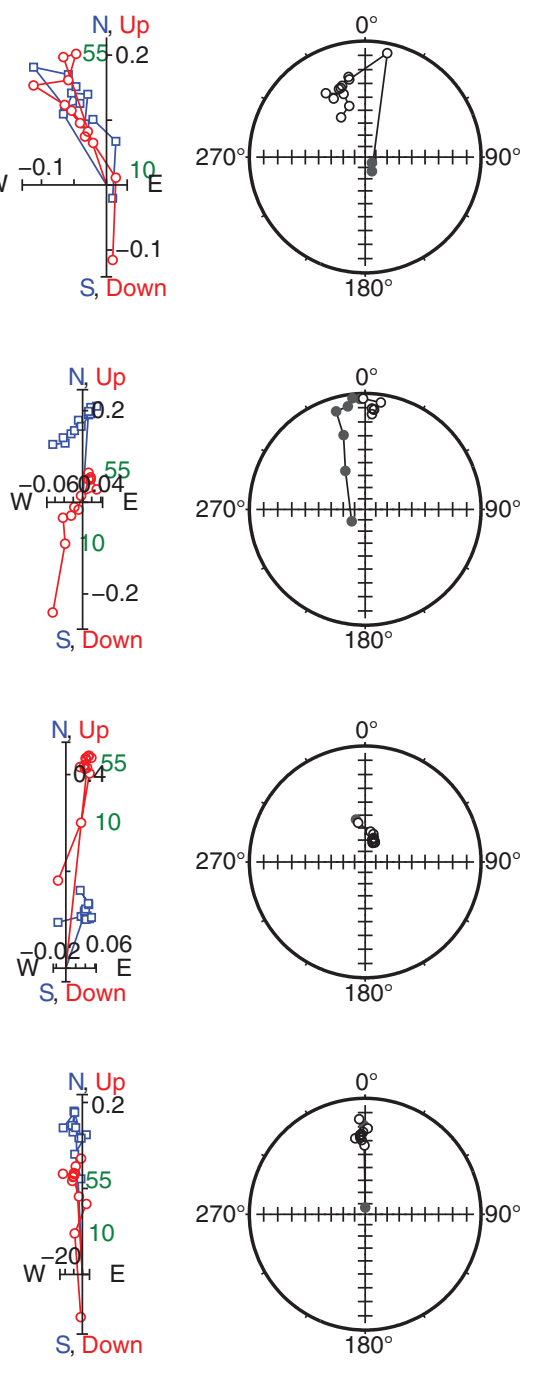
Figure F33. Suite of physical properties measured in Holes U1423A and U1423B. The first magnetic susceptibility panel shows WRMSL data of Holes U1423A (red) and U1423B (black), whereas the second panel shows WRSML data of Hole U1423B (black) and point SHMSL susceptibility data of Holes U1423A (blue) and U1423B (green). WRMSL gamma ray attenuation (GRA) bulk density is from Holes U1423A (red) and U1423B (black). Natural gamma radiation (NGR) is from in Holes U1423A (light blue) and U1423B (black). P-wave velocity panel shows combined WRMSL data of Holes U1423A and U1423B. Dashed horizontal lines = lithologic subunit boundaries, solid horizontal line = lithologic Unit I/II boundary.

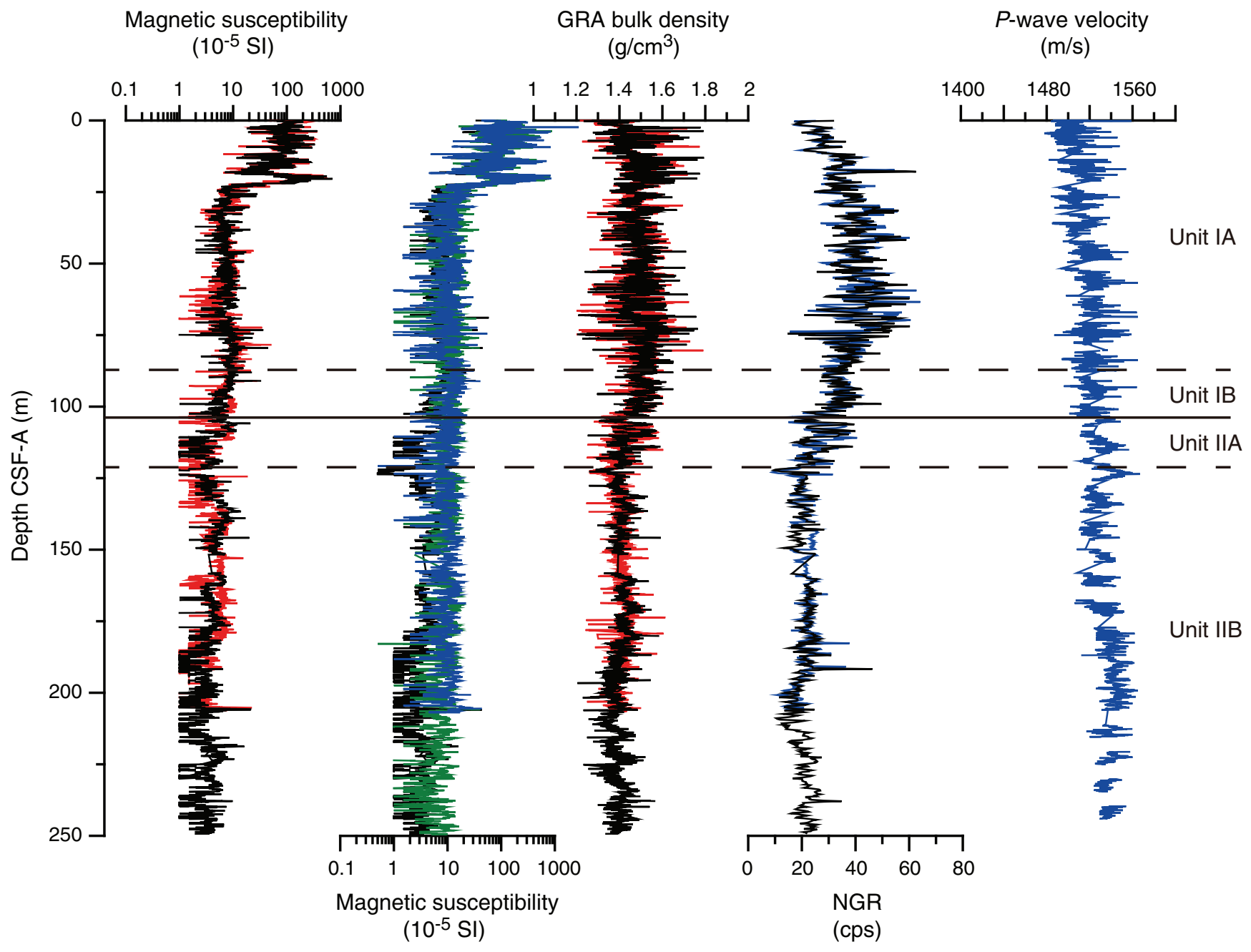


Figure F34. $P$-wave velocity measured with the WRMSL before $\left(\sim 12^{\circ} \mathrm{C}\right.$; black $)$ and after $\left(\sim 20^{\circ} \mathrm{C}\right.$; blue $)$ temperature equilibrium in Cores 346-U1423B-3H, 7H, and $16 \mathrm{H}$.

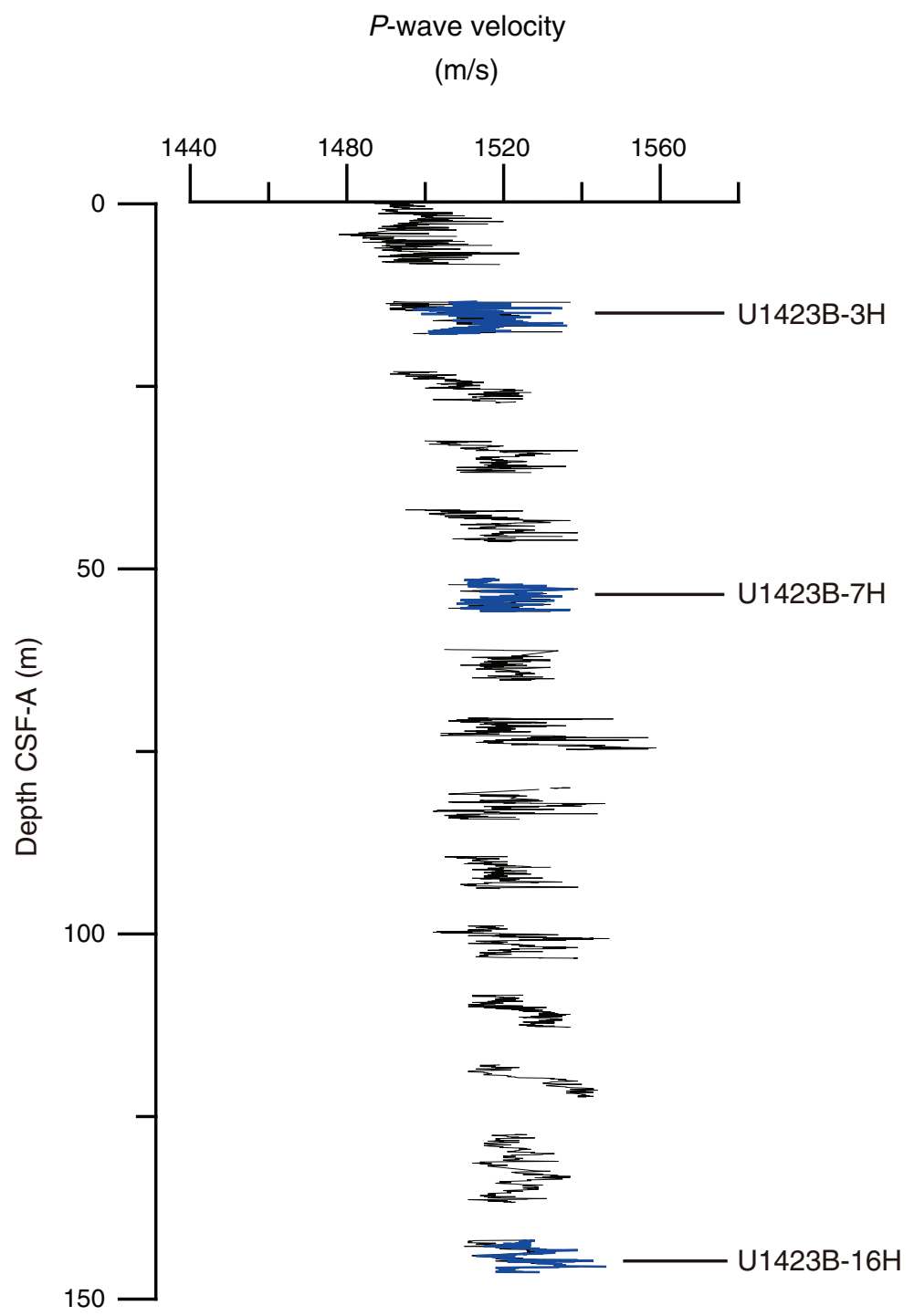


Figure F35. Discrete bulk density, grain density, porosity, water content, and shear strength, Site U1423. Dashed horizontal lines = lithologic subunit boundaries, solid horizontal line = lithologic Unit I/II boundary.

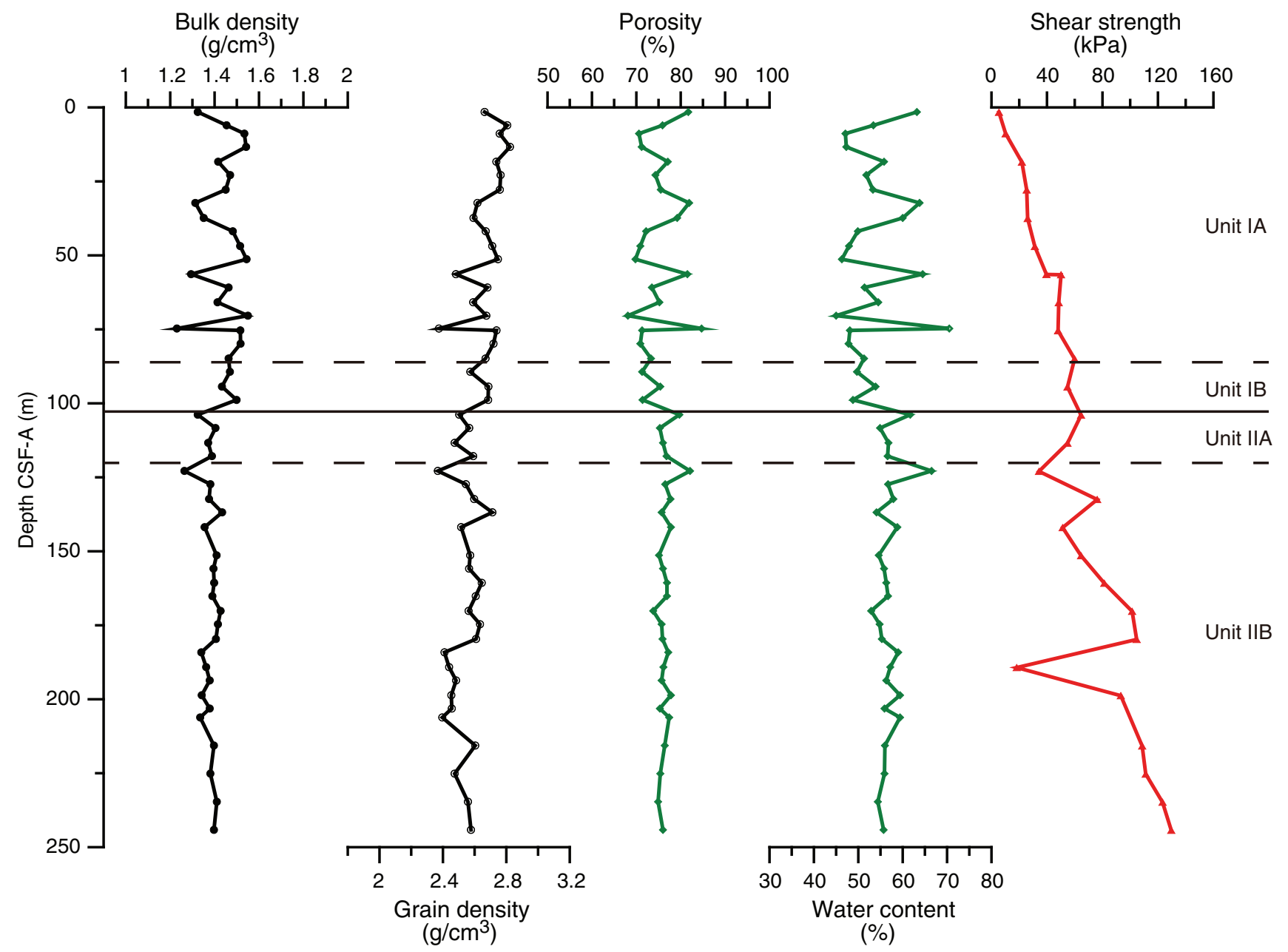


Figure F36. Color reflectance $\left(\mathrm{L}^{*}, \mathrm{a}^{*}\right.$, and $\mathrm{b}^{*}$ ) in Holes U1423A (black, red, and dark blue lines) and U1423B (gray, orange, and light blue lines). Dashed horizontal lines = lithologic subunit boundaries, solid horizontal line = lithologic Unit I/II boundary.

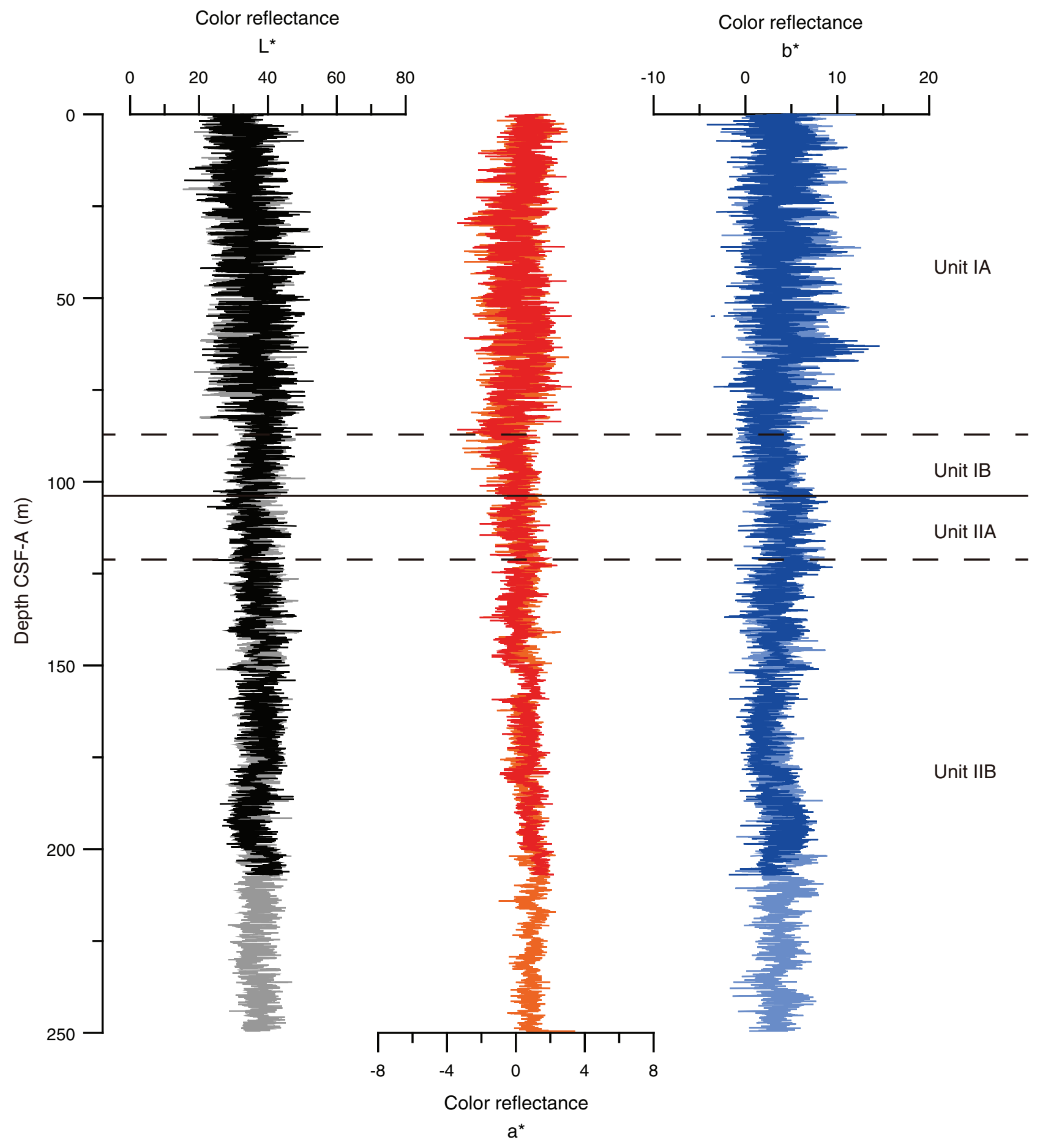


Figure F37. Downhole logs and logging units, Hole U1423B. HSGR = standard (total) gamma radiation, NGR = natural gamma radiation, RLA1 = shallow apparent resistivity, RLA5 = deep apparent resistivity, MS = magnetic susceptibility.

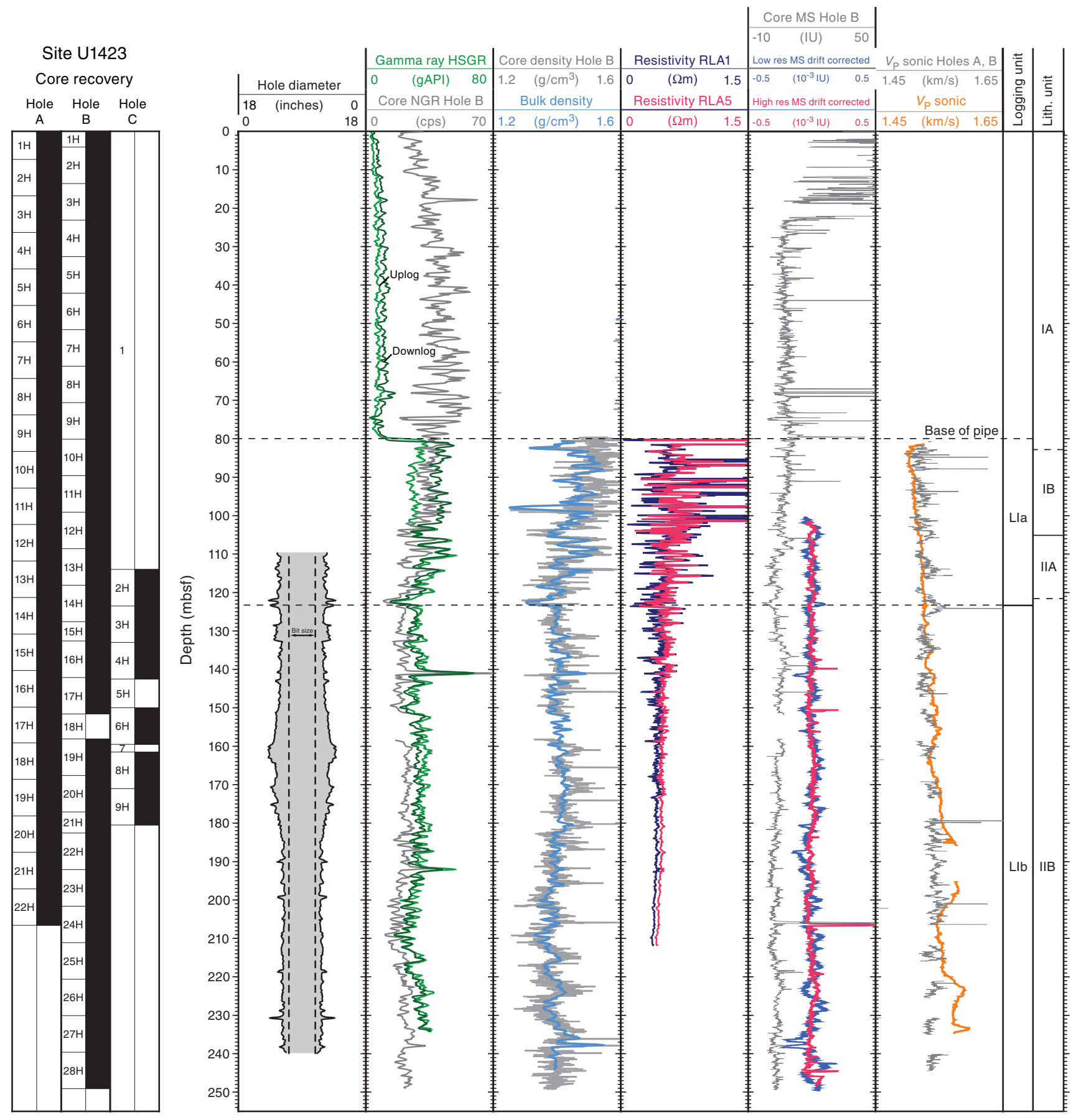


Figure F38. Natural gamma radiation downlogs (not corrected for variations in hole diameter), straight (nonoriented) Formation MicroScanner (FMS) images, and logging units, Hole U1423B. HSGR = standard (total) gamma radiation, $\mathrm{HCGR}=$ computed gamma radiation.

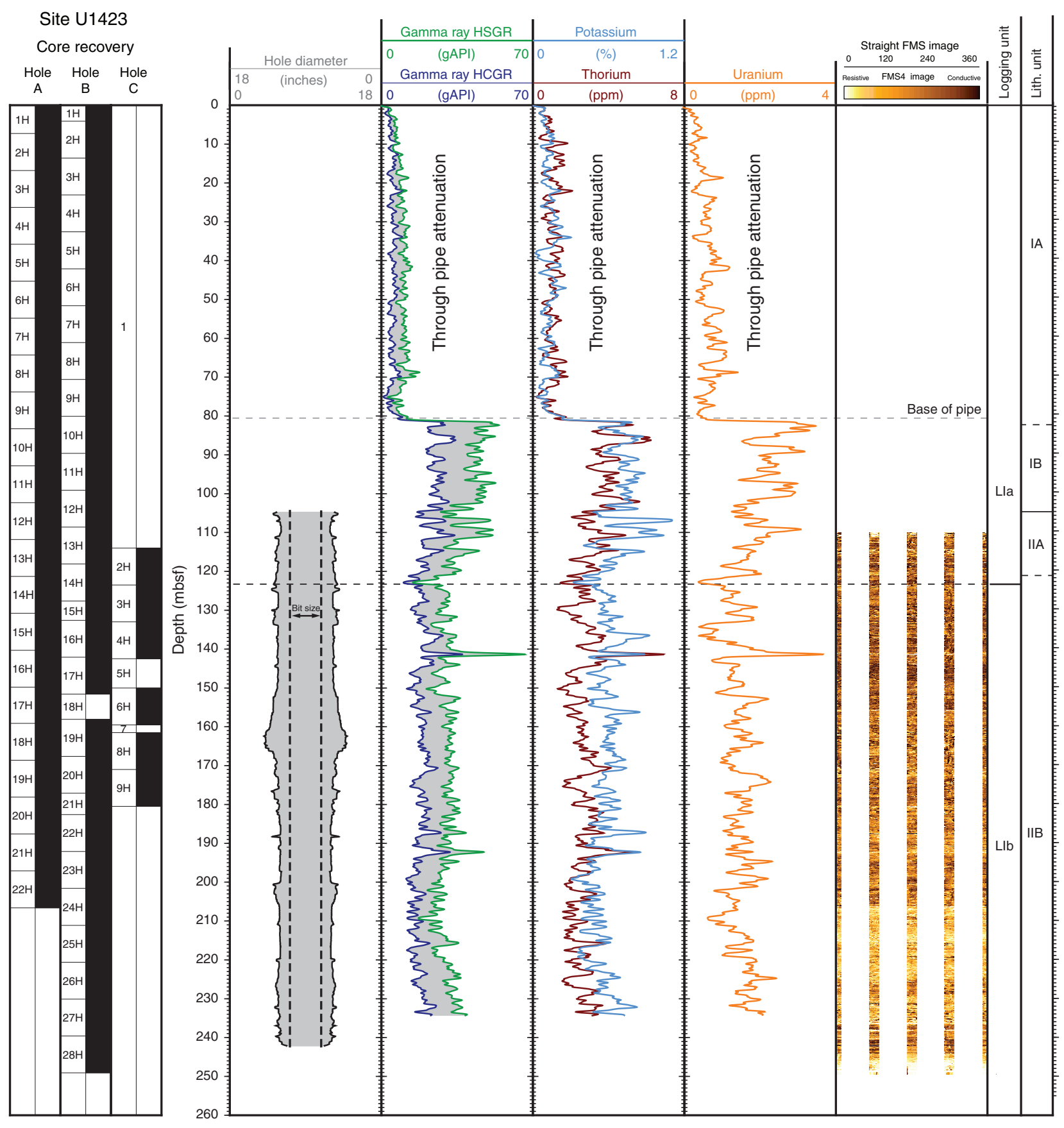


Figure F39. Logging operations summary diagram, Site U1423. FMS = Formation MicroScanner.

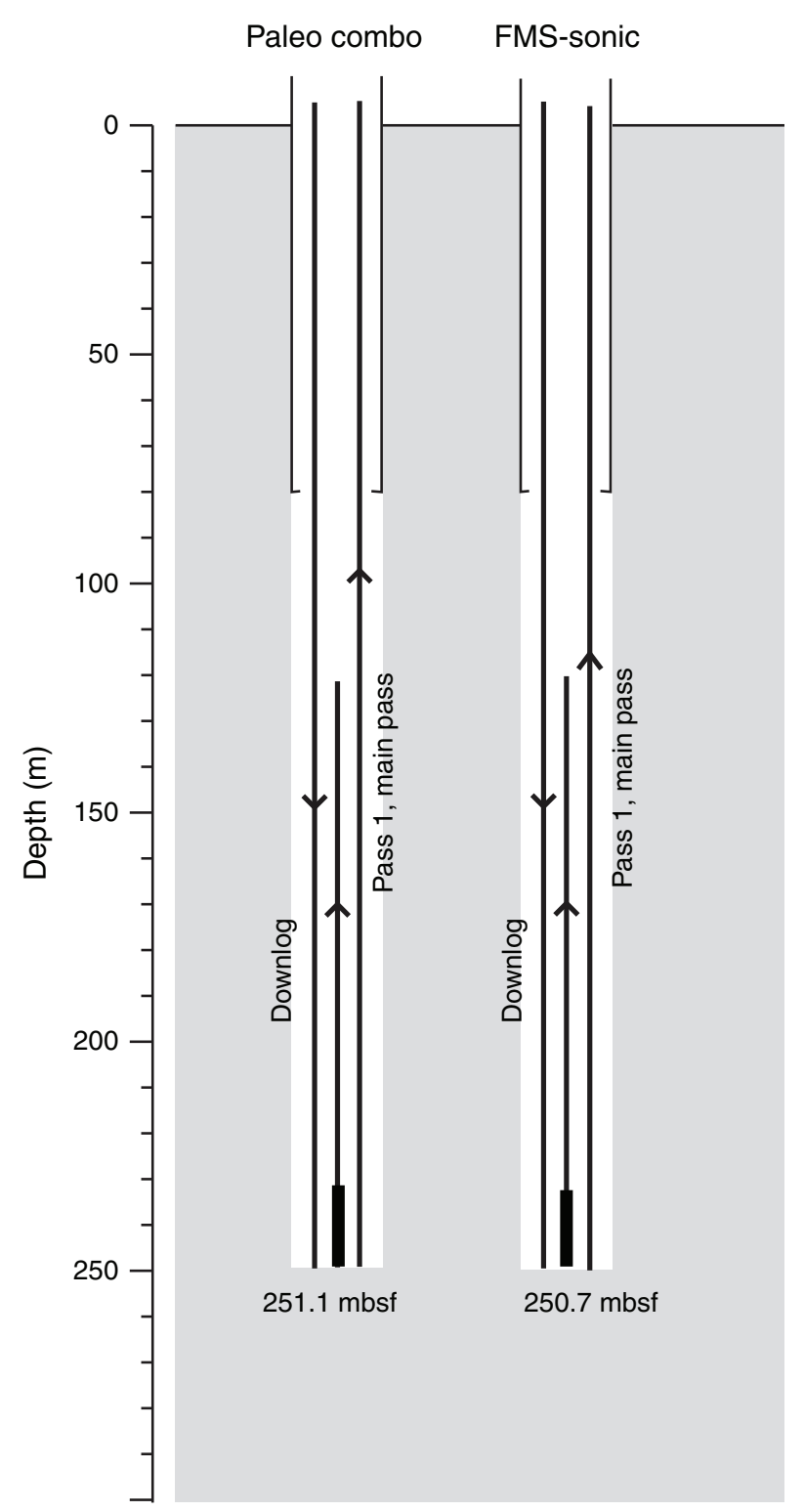


Figure F40. Correlation of downhole logs and lithology (110-126 mbsf) in Hole U1423B. The good hole condition allowed the Formation MicroScanner (FMS) pads to have good contact with the borehole wall and gave good images. NGR = natural gamma radiation, $\mathrm{RHOM}=$ high-resolution bulk density log, $\mathrm{HSGR}=$ standard (total) gamma radiation, RA5 = deep apparent resistivity.

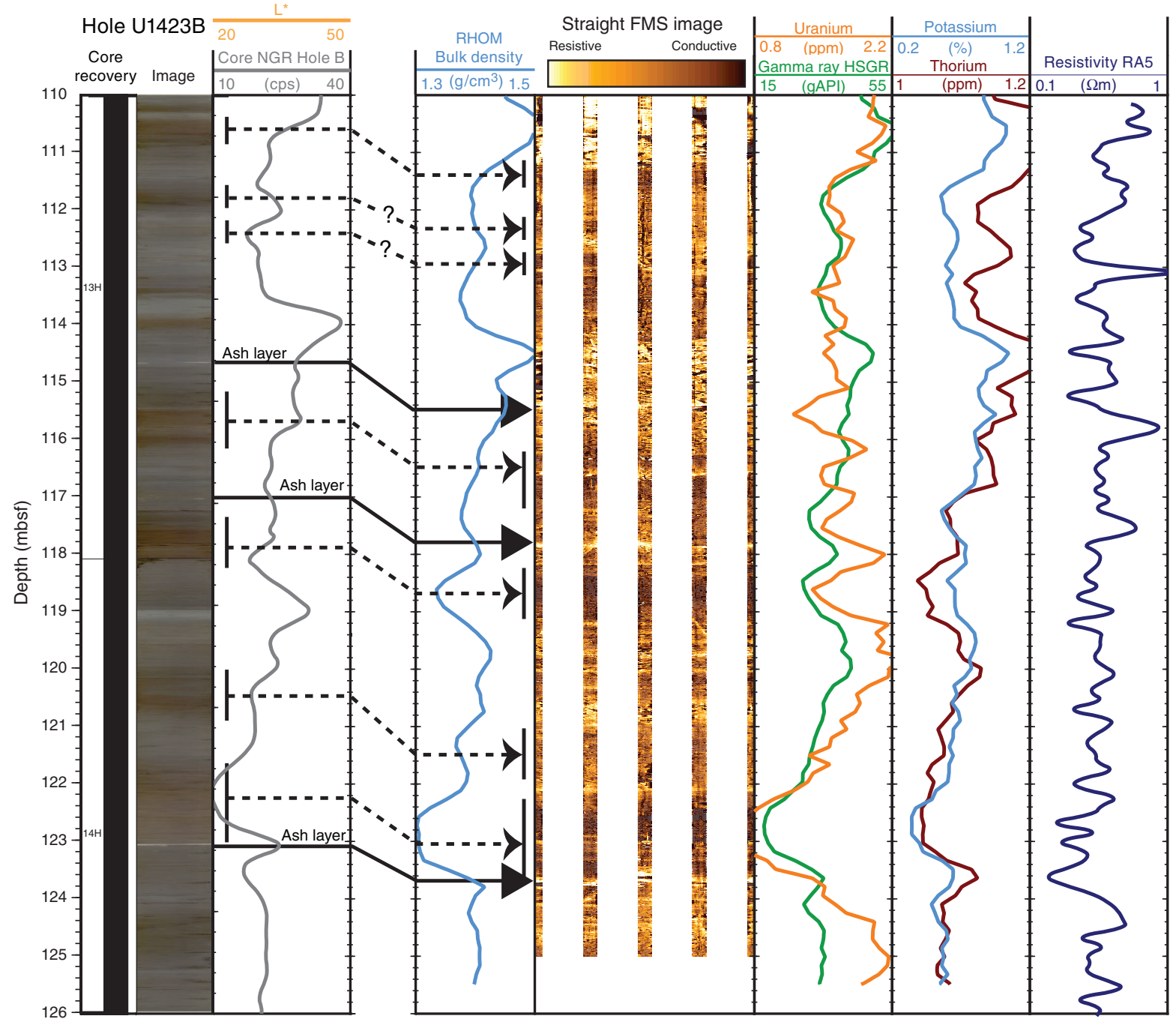


Figure F41. Correlation of downhole logs and lithology (230-243 mbsf) in Hole U1423B indicates that ash layers are more resistive than neighboring beds. $\mathrm{RHOM}=$ high-resolution bulk density $\log$, FMS = Formation MicroScanner.

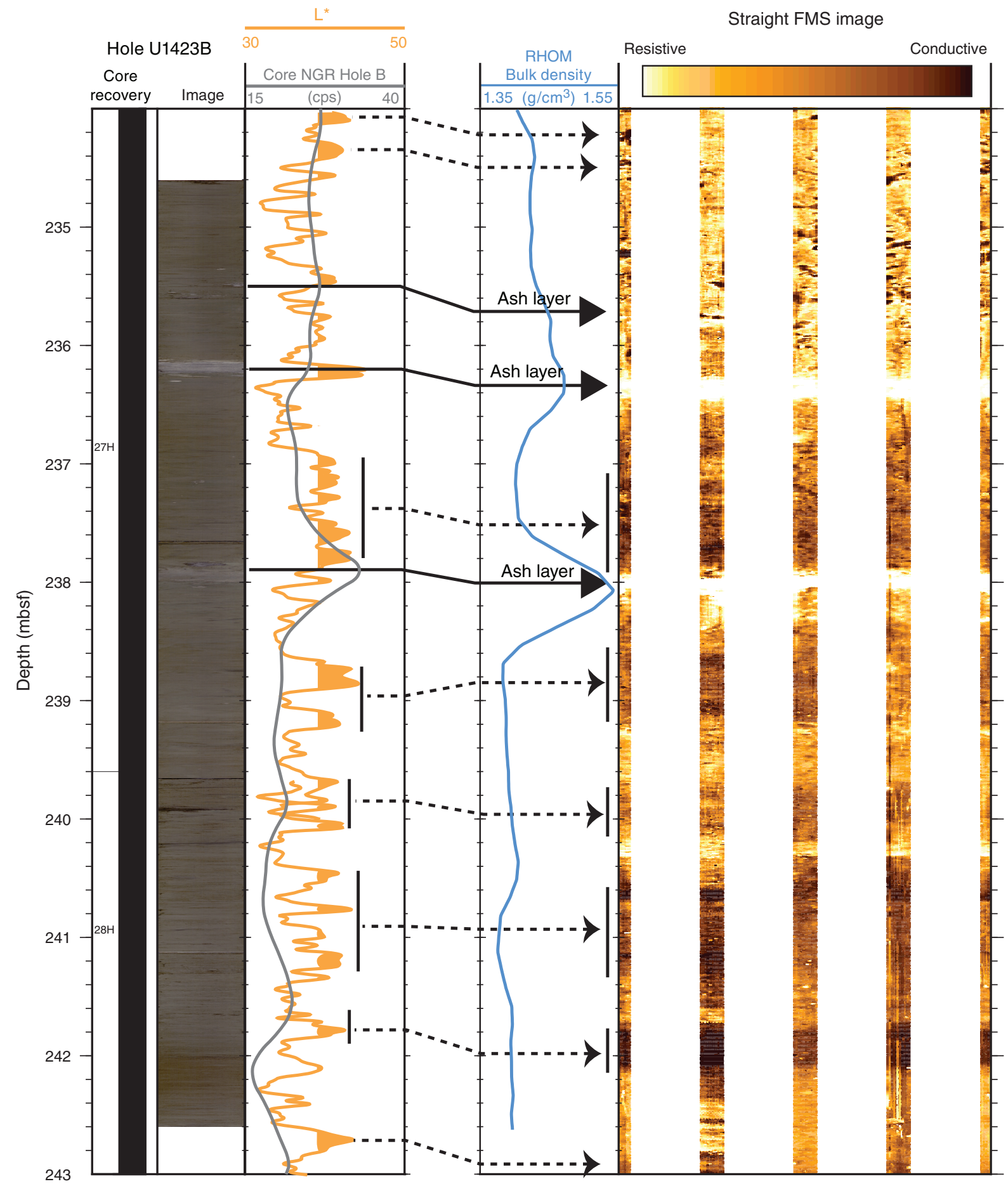


Figure F42. Plots of heat flow calculations, Hole U1423A. A. In situ sediment temperatures from advanced piston corer temperature tool (APCT-3) measurements with average values for Cores 346-U1423A-4H, 7H, 10H, and $13 \mathrm{H}$ (circles) and linear fit. B. In situ thermal conductivity data (squares) with calculated thermal resistance (solid line). C. Bullard plot of heat flow calculated from a linear fit of temperature vs. thermal resistance data.

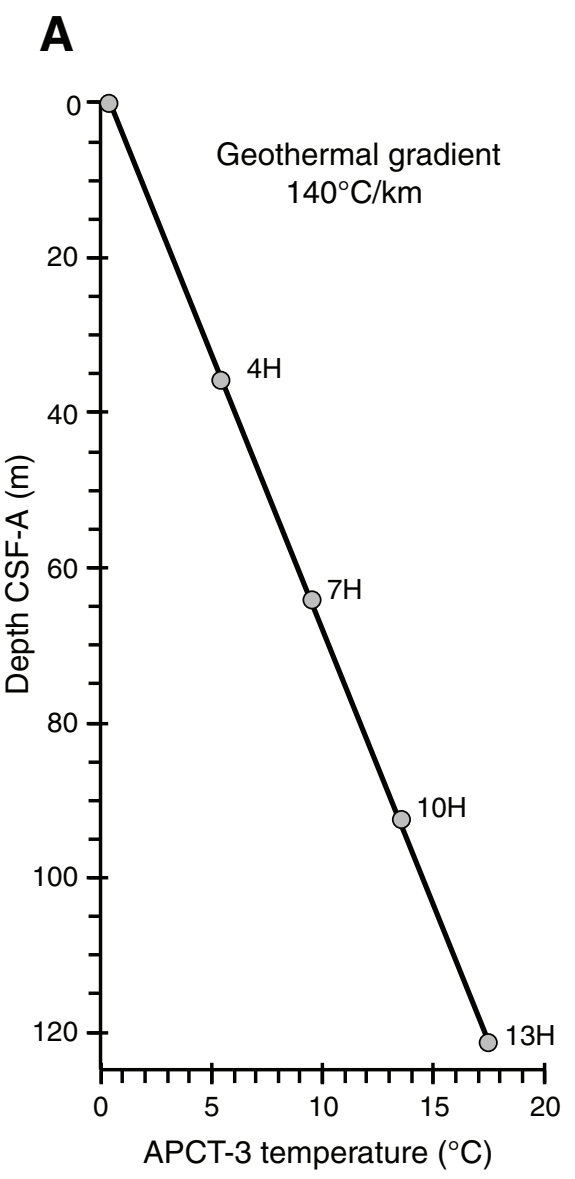

B Thermal resistance $\left(\mathrm{m}^{2} \mathrm{~K} / \mathrm{W}\right)$

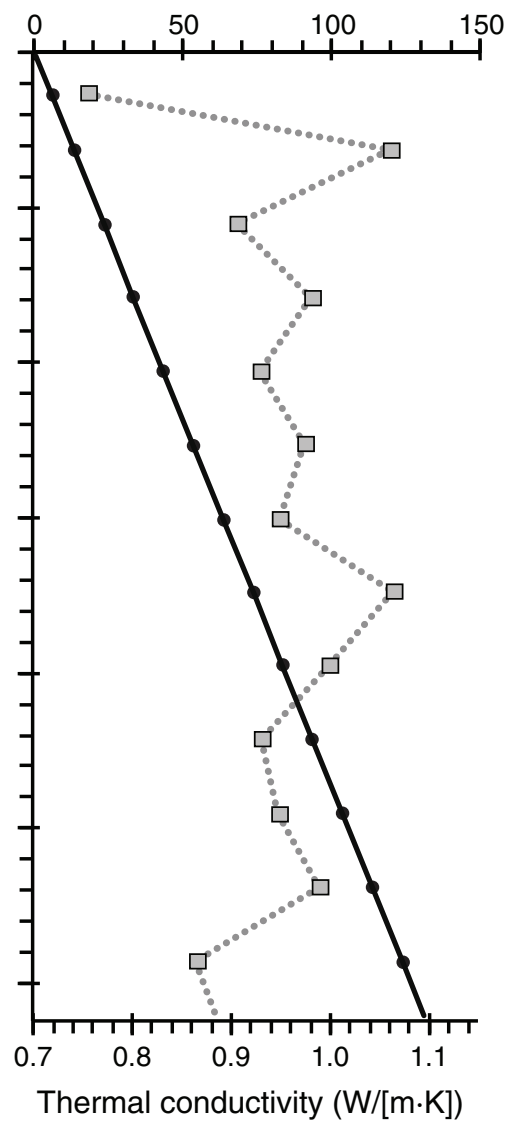

C

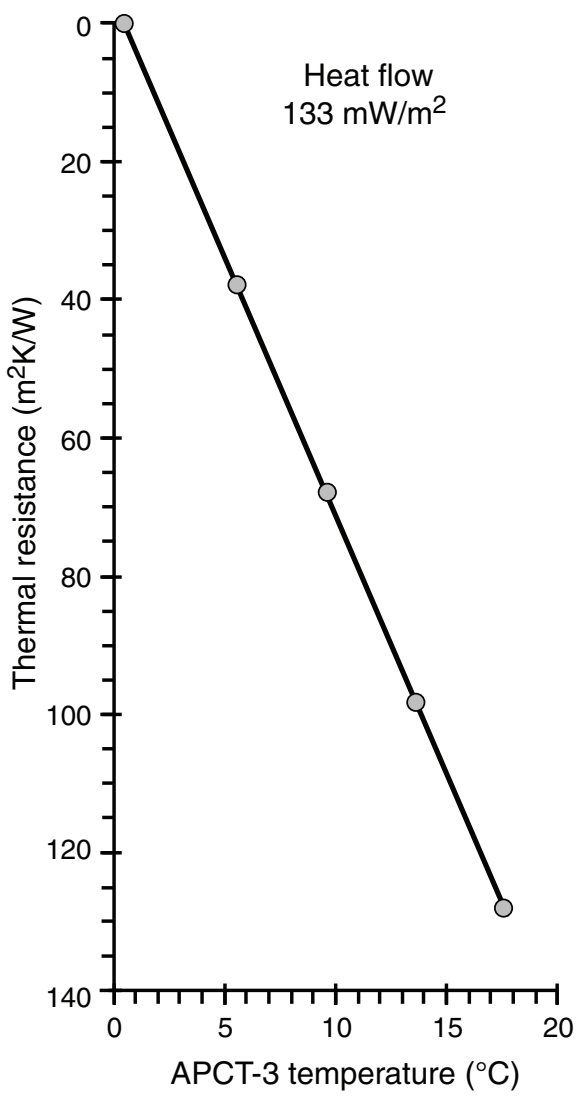


Figure F43. Composited cores and splice for Site U1423. Each core is adjusted (in depth) by a constant amount to align it with adjacent cores at a chosen tie point (typically a distinctive feature in all of the data sets). Other features may or may not align among adjacent cores because of differential squeezing and stretching during the coring process or to variable expansion characteristics. The splice is constructed from the composited cores by selecting intervals from different holes such that coring gaps are avoided and drilling disturbance is minimized. Data included in the splice are plotted on the CCSF-D scale, whereas data not included in the splice are plotted on the CCSF-A scale. Horizontal light blue lines indicate tie points where the splice changes from one hole to another. Only the splice is plotted on the correct $y$-axis scale; data from Holes U1423A, U1423B, and U1423C are offset by 40, 80, or 120 units, respectively, for illustrative purposes. One and two point spikes are artifacts generated when the track sensor measures beyond the end of the $\sim 150 \mathrm{~cm}$ sections. The gap in the splice data at $90 \mathrm{~m}$ results from missing image data; it does not reflect a gap in the lithologic section. A. 0-50 m CCSF-A. (Continued on next two pages.)

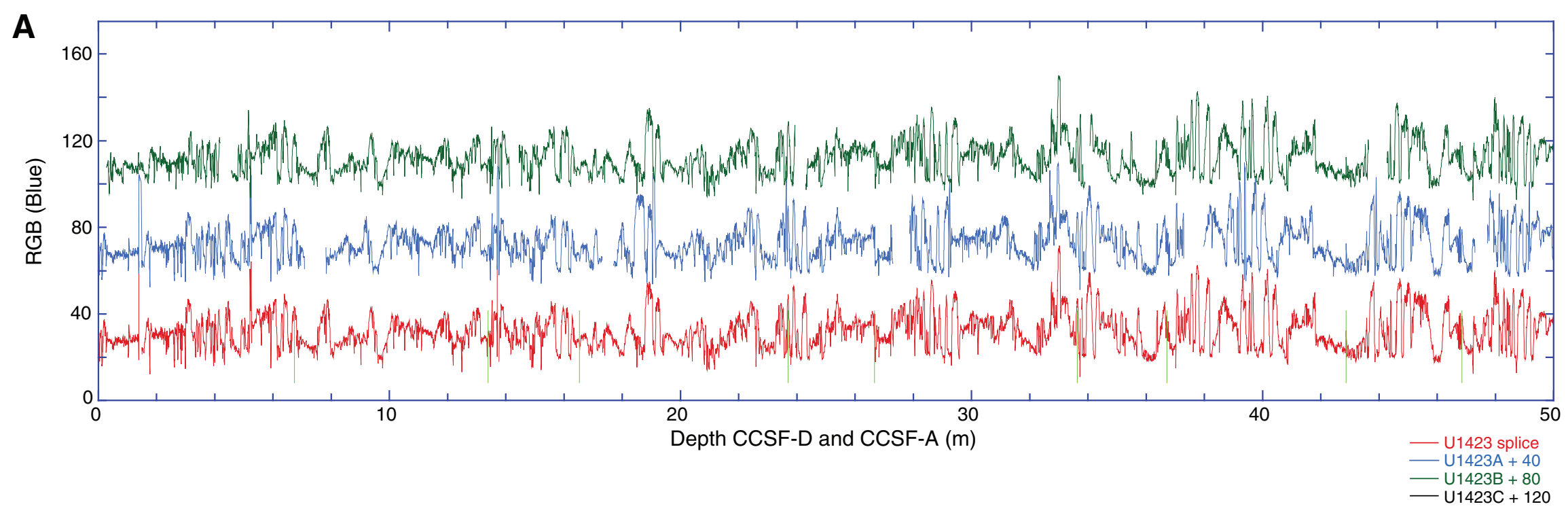



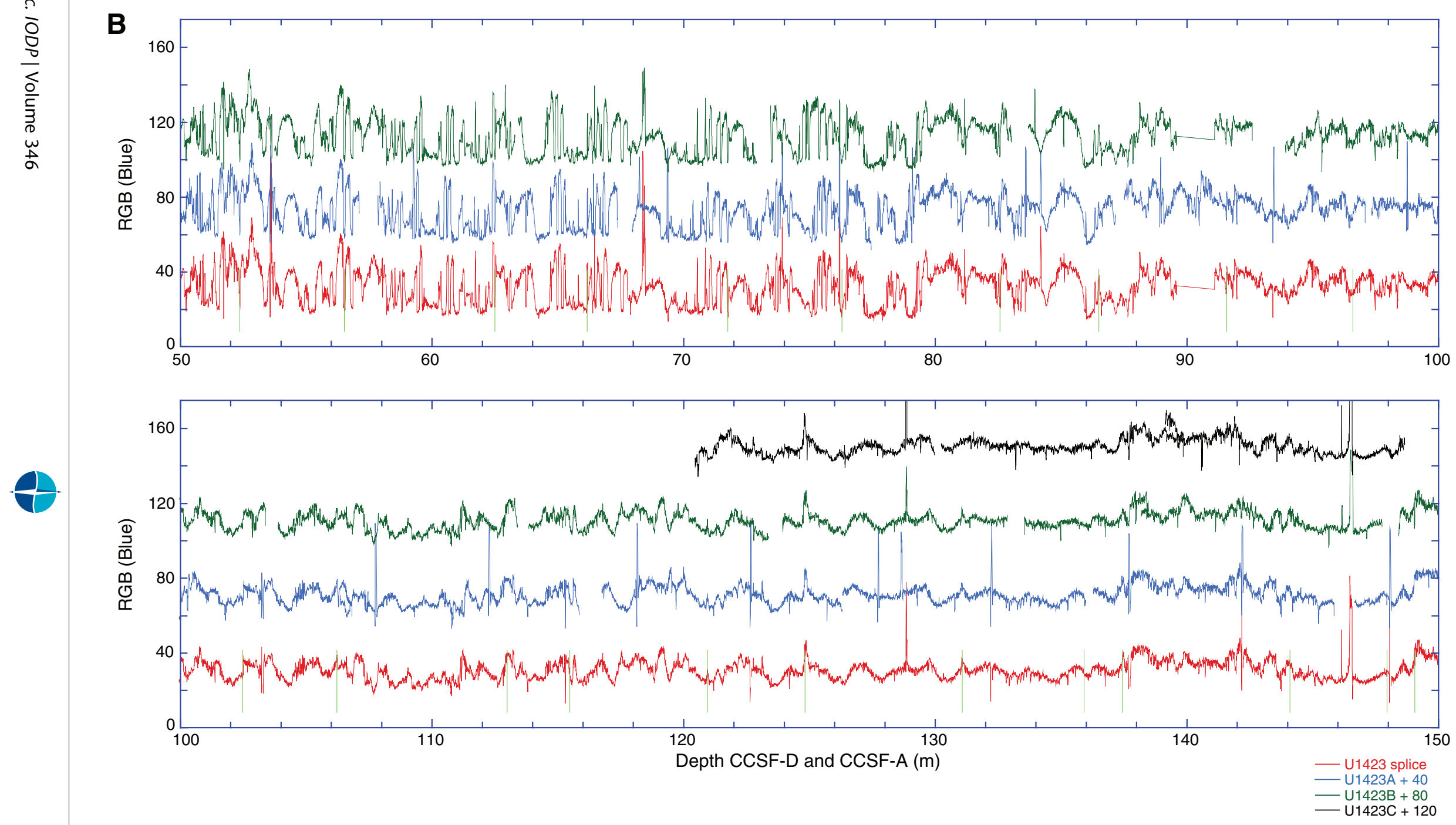
Figure F43 (continued). C. 150-225 m CCSF-A.
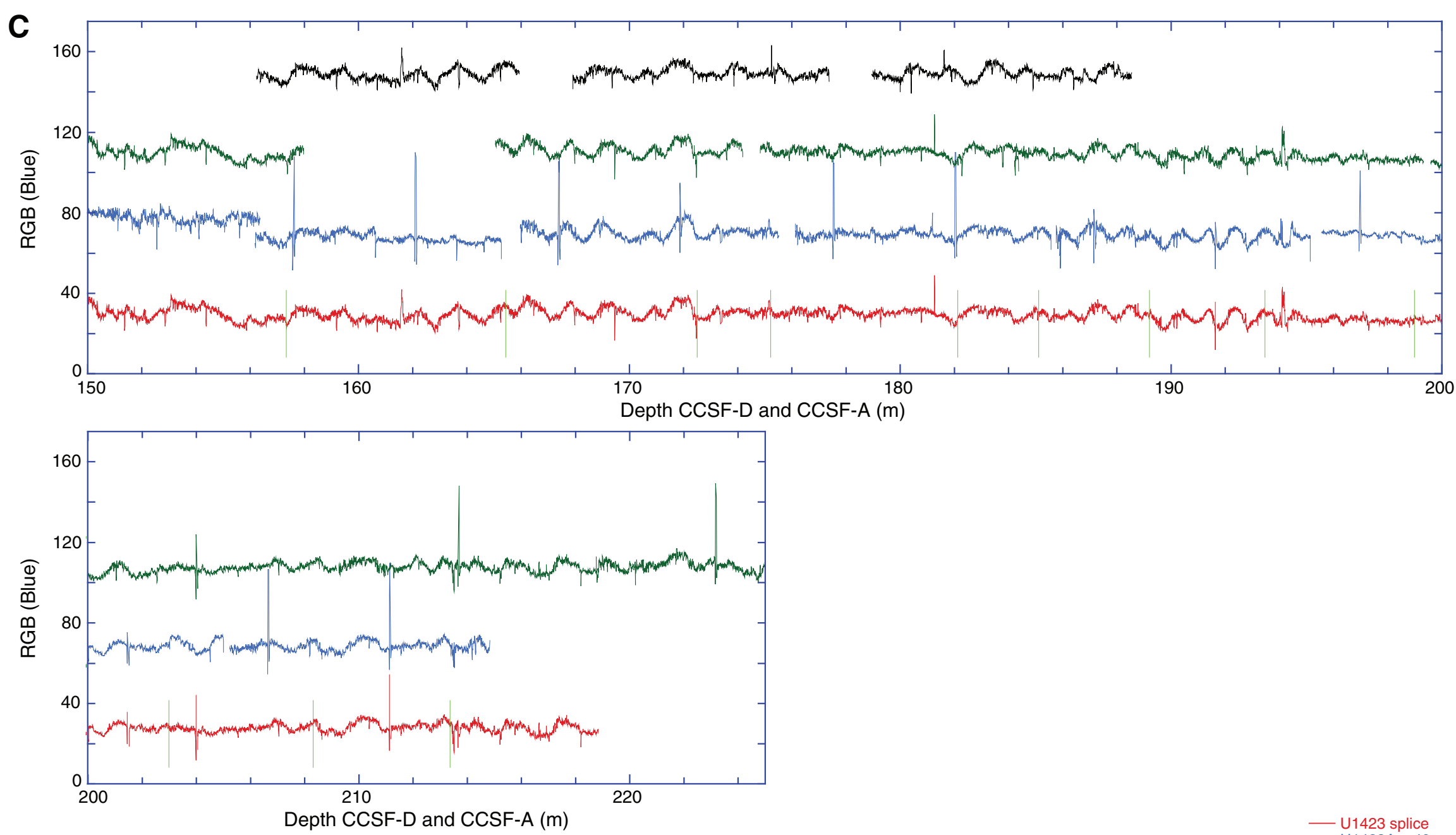
Figure F44. Age model and sedimentation rates, Site U1423. A. Synthesis of biostratigraphic and paleomagnetic age control points to establish a preliminary age model. B. Average sedimentation rates calculated between age control points.

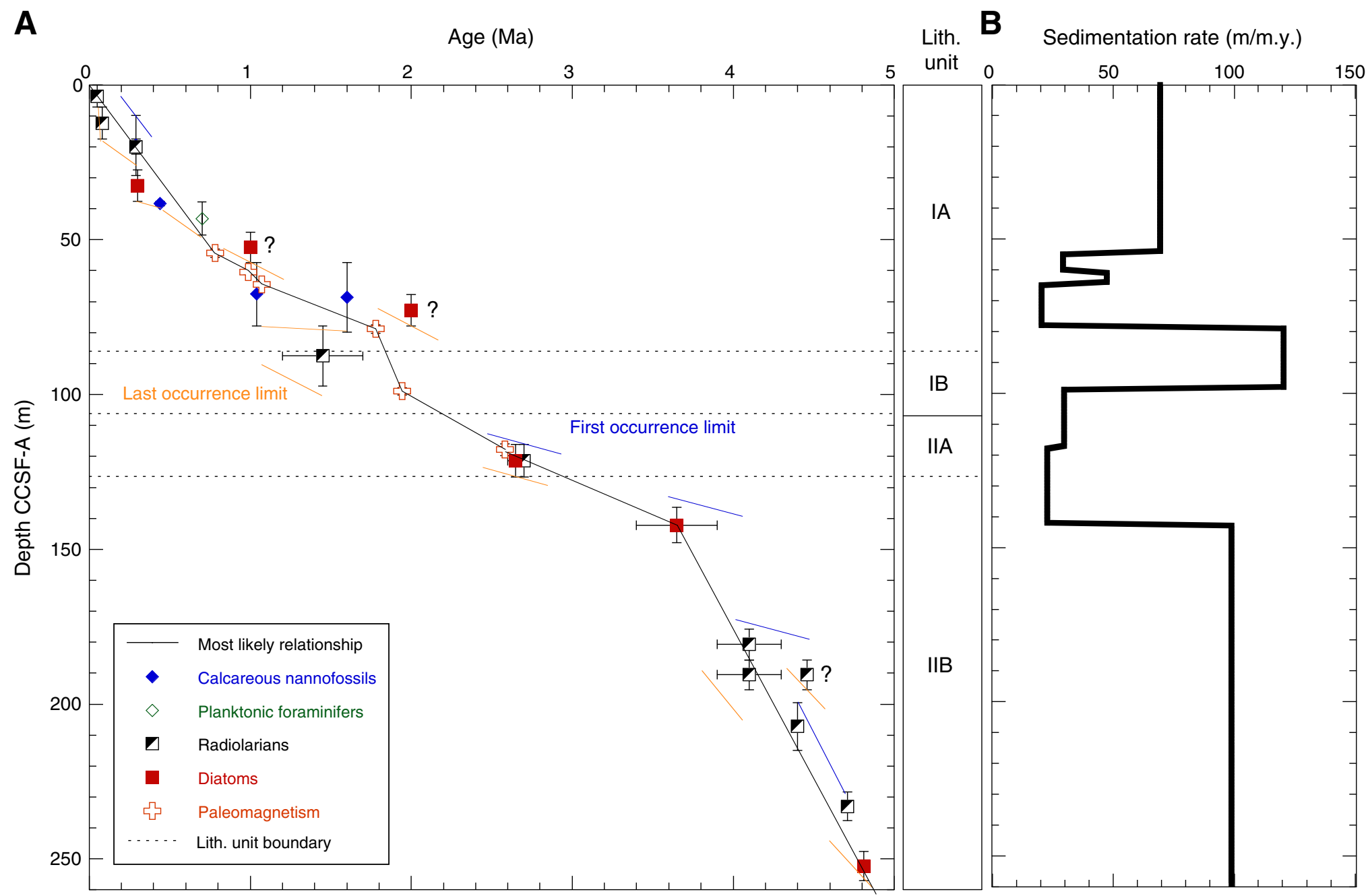


Table T1. Coring summary, Site U1423. (Continued on next page.)

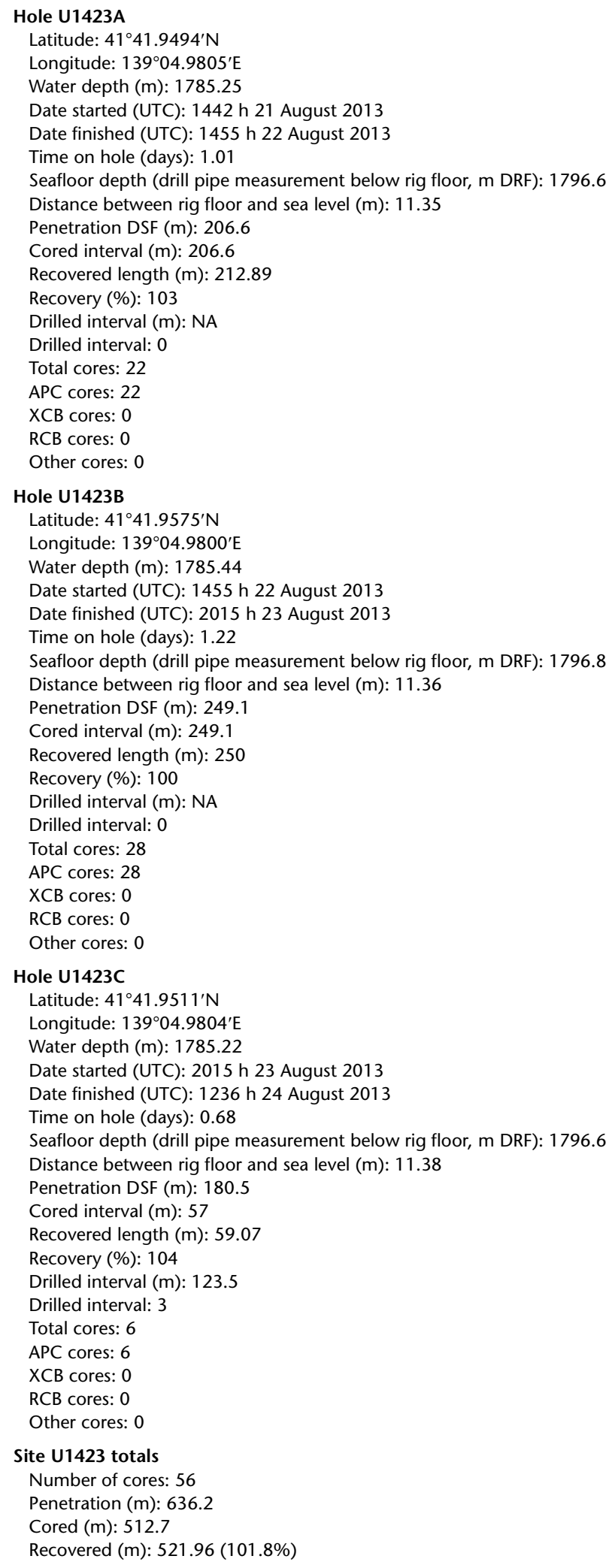


Table T1 (continued).

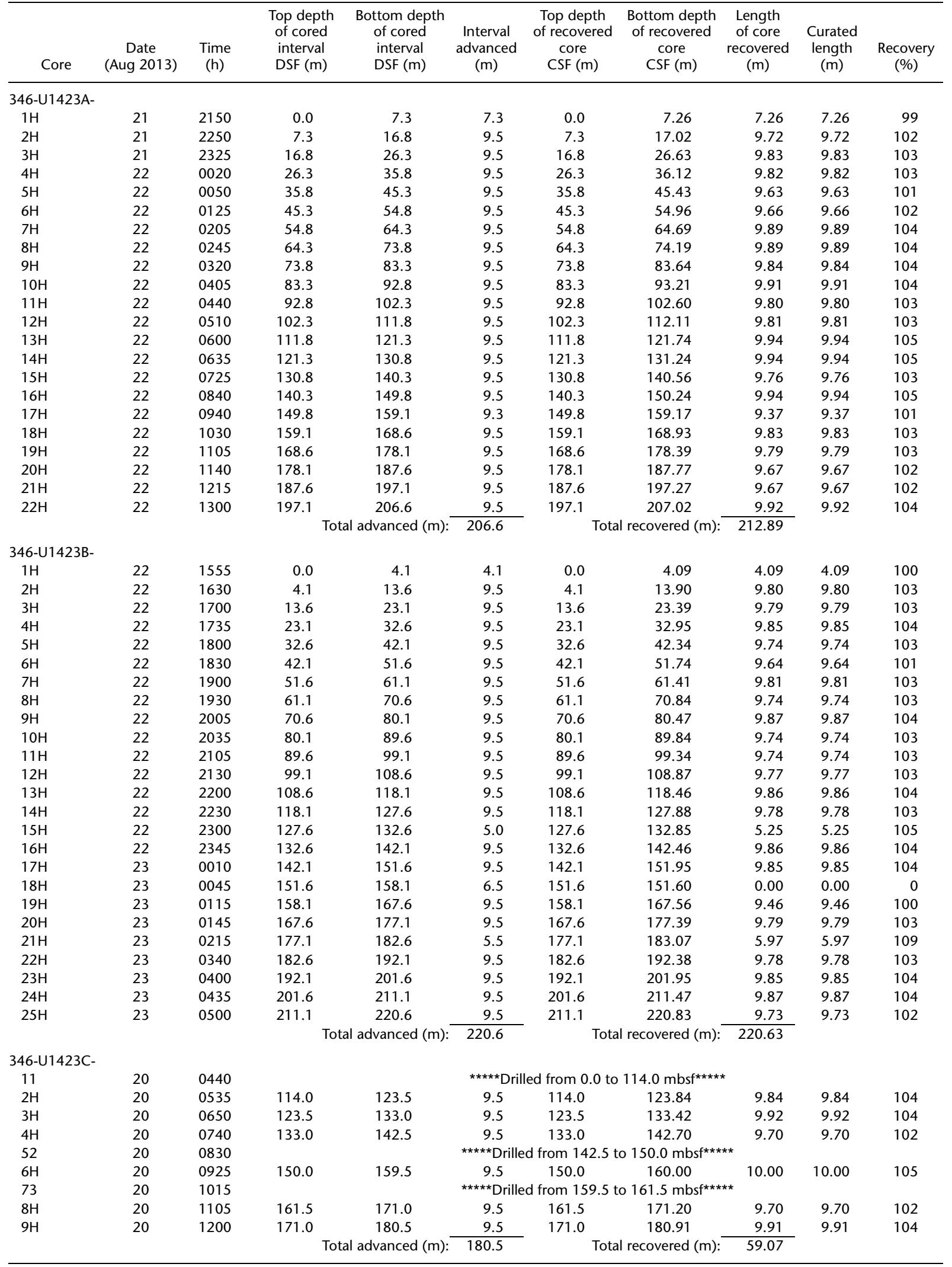

$\mathrm{DRF}=$ drilling depth below rig floor, $\mathrm{DSF}=$ drilling depth below seafloor, $\mathrm{CSF}=$ core depth below seafloor. $\mathrm{APC}=\mathrm{advanced}$ piston corer, $\mathrm{XCB}=$ extended core barrel, $\mathrm{RCB}=$ rotary core barrel. $\mathrm{H}=\mathrm{APC}$ system, numeric core type = drilled interval. $\mathrm{NA}=$ not applicable. 
Table T2. Visible tephra layers thicker than $0.5 \mathrm{~cm}$, Hole U1423A.

\begin{tabular}{|c|c|c|c|}
\hline $\begin{array}{l}\text { Core, section, } \\
\text { interval }(\mathrm{cm})\end{array}$ & $\begin{array}{l}\text { Thickness } \\
\text { (cm) }\end{array}$ & Color & Occurrence \\
\hline \multicolumn{4}{|l|}{ 346-U1423A- } \\
\hline $1 \mathrm{H}-2,112-113$ & 1.0 & Dark gray & Layered \\
\hline $1 \mathrm{H}-3,95-104$ & 2.0 & Light gray & Layered \\
\hline $1 \mathrm{H}-4,72-77$ & 5.0 & White & Layered \\
\hline $1 \mathrm{H}-5,26-30$ & 1.3 & White & Patched \\
\hline $2 \mathrm{H}-4,126-127$ & 1.0 & White & Layered \\
\hline $3 \mathrm{H}-1,52-52.5$ & 0.5 & Black & Layered \\
\hline $3 \mathrm{H}-2,89-90$ & 1.0 & Dark gray & Layered \\
\hline $3 \mathrm{H}-3,19-20$ & 1.0 & Gray & Layered \\
\hline $3 \mathrm{H}-3,38-45$ & 2.0 & Gray & Layered \\
\hline $3 \mathrm{H}-3,112-113.5$ & 1.5 & Light gray-gray & Layered \\
\hline $3 \mathrm{H}-4,44-45$ & 1.0 & Dark gray & Layered \\
\hline $3 \mathrm{H}-5,14-15$ & 1.0 & Gray & Layered \\
\hline $3 \mathrm{H}-5,34-35$ & 1.0 & Gray & Layered \\
\hline $3 \mathrm{H}-7,15-16$ & 1.0 & Light gray & Layered \\
\hline $4 \mathrm{H}-3,44-45$ & 1.0 & Gray & Layered \\
\hline $4 \mathrm{H}-3,109.5-110.5$ & 1.0 & Gray & Layered \\
\hline $4 \mathrm{H}-4,10-12$ & 2.0 & Gray & Layered \\
\hline $4 \mathrm{H}-5,8-8.5$ & 0.5 & Light gray & Layered \\
\hline $5 \mathrm{H}-3,90-91$ & 1.0 & Gray & Layered \\
\hline $6 \mathrm{H}-1,11-27$ & 16.0 & Light gray & Layered \\
\hline $6 \mathrm{H}-5,19-20$ & 1.0 & Light gray & Layered \\
\hline $6 \mathrm{H}-6,100.5-101$ & 0.5 & Light gray & Layered \\
\hline 7H-1, 14-18 & 4.0 & Light gray-gray & Layered \\
\hline $7 \mathrm{H}-1,37-37.5$ & 0.5 & Gray & Layered \\
\hline 7H-3, 88-91 & 3.0 & Light gray-gray & Layered \\
\hline 7H-6, 51-52 & 1.0 & Light gray & Layered \\
\hline $7 \mathrm{H}-6,88-89$ & 1.0 & Light gray & Layered \\
\hline 7Н-6, 112-113 & 1.0 & Light gray & Layered \\
\hline $8 \mathrm{H}-1,34-38$ & 4.0 & White & Layered \\
\hline $8 \mathrm{H}-2,131-133$ & 0.7 & Light gray & Patched \\
\hline $8 \mathrm{H}-5,3-5$ & 2.0 & Light gray & Layered \\
\hline $8 \mathrm{H}-6,18-20$ & 2.0 & Light gray & Layered \\
\hline $8 \mathrm{H}-6,23.5-25$ & 1.5 & Light gray & Layered \\
\hline $8 \mathrm{H}-6,56-59$ & 1.0 & Light gray & Patched \\
\hline $8 \mathrm{H}-6,80-82$ & 2.0 & White & Layered \\
\hline $8 \mathrm{H}-7,46-49$ & 3.0 & Light gray & Layered \\
\hline $9 \mathrm{H}-1,124-126$ & 2.0 & Gray & Layered \\
\hline $9 \mathrm{H}-3,39-41$ & 2.0 & Light gray & Layered \\
\hline $9 \mathrm{H}-5,56-62$ & 6.0 & Light gray & Layered \\
\hline $9 \mathrm{H}-6,85-86$ & 1.0 & Gray & Layered \\
\hline $10 \mathrm{H}-1,43.5-47$ & 1.2 & Light gray & Patched \\
\hline $10 \mathrm{H}-3,106-109.5$ & 3.5 & Light gray & Layered \\
\hline $11 \mathrm{H}-1,42-46$ & 1.3 & Light gray-gray & Patched \\
\hline $11 \mathrm{H}-6,91-94.5$ & 1.2 & Gray & Patched \\
\hline $11 \mathrm{H}-6,112-115$ & 3.0 & White & Patched \\
\hline $13 \mathrm{H}-3,29.5-31$ & 0.5 & White & Patched \\
\hline $13 \mathrm{H}-5,7-22$ & 15.0 & White & Layered \\
\hline $14 \mathrm{H}-2,86.5-91.5$ & 5.0 & Light gray & Layered \\
\hline $14 \mathrm{H}-2,99.5-101$ & 0.5 & Light gray & Patched \\
\hline $19 \mathrm{H}-4,55-61$ & 6.0 & Light gray & Layered \\
\hline $20 \mathrm{H}-1,81-84$ & 3.0 & Light gray & Layered \\
\hline $20 \mathrm{H}-1,127-130$ & 3.0 & Gray & Layered \\
\hline $20 \mathrm{H}-3,93-95$ & 2.0 & Gray & Layered \\
\hline $20 \mathrm{H}-6,77-94$ & 17.0 & White-light gray & Layered \\
\hline
\end{tabular}


Table T3. XRD analysis of bulk samples, Site U1423.

\begin{tabular}{|c|c|c|c|c|c|c|c|c|c|c|c|}
\hline $\begin{array}{l}\text { Core section, } \\
\text { interval }(\mathrm{cm})\end{array}$ & $\begin{array}{l}\text { Top depth } \\
\text { CSF-A (m) }\end{array}$ & $\begin{array}{l}\text { Smectite } \\
\text { (counts) }\end{array}$ & $\begin{array}{c}\text { Illite } \\
\text { (counts) }\end{array}$ & $\begin{array}{l}\text { Kaolinite } \\
+ \text { chlorite } \\
\text { (counts) }\end{array}$ & $\begin{array}{l}\text { Opal-A } \\
\text { (counts) }\end{array}$ & $\begin{array}{l}\text { Quartz } \\
\text { (counts) }\end{array}$ & $\begin{array}{l}\text { K-feldspar } \\
\text { (counts) }\end{array}$ & $\begin{array}{l}\text { Plagioclase } \\
\text { (counts) }\end{array}$ & $\begin{array}{l}\text { Calcite } \\
\text { (counts) }\end{array}$ & $\begin{array}{l}\text { Halite } \\
\text { (counts) }\end{array}$ & $\begin{array}{l}\text { Pyrite } \\
\text { (counts) }\end{array}$ \\
\hline \multicolumn{12}{|l|}{ 346-U1423A- } \\
\hline $1 \mathrm{H}-2,100.0-101.0$ & 2.5 & 304 & 562 & 474 & 0 & 4033 & 301 & 718 & 977 & 299 & 343 \\
\hline $2 \mathrm{H}-1,122.0-123.0$ & 8.52 & 250 & 176 & 164 & 9 & 3787 & 0 & 713 & 113 & 284 & 68 \\
\hline $3 \mathrm{H}-1,90.0-91.0$ & 17.7 & 194 & 545 & 319 & 10 & 5193 & 294 & 777 & 365 & 177 & 0 \\
\hline $4 \mathrm{H}-1,52.0-53.0$ & 26.82 & 276 & 606 & 431 & 0 & 5222 & 287 & 702 & 130 & 279 & 0 \\
\hline $6 \mathrm{H}-1,95.0-96.0$ & 46.25 & 212 & 481 & 357 & 4 & 5017 & 220 & 680 & 91 & 241 & 53 \\
\hline $7 \mathrm{H}-1,81.0-82.0$ & 55.61 & 154 & 275 & 227 & 46 & 4393 & 228 & 593 & 0 & 221 & 87 \\
\hline $8 \mathrm{H}-1,86.0-87.0$ & 65.16 & 232 & 208 & 150 & 44 & 3616 & 0 & 664 & 0 & 254 & 84 \\
\hline $8 \mathrm{H}-5,74.5-75.5$ & 71.045 & 215 & 186 & 150 & 50 & 4006 & 0 & 692 & 0 & 187 & 132 \\
\hline $9 \mathrm{H}-1,133.0-134.0$ & 75.13 & 238 & 505 & 381 & 30 & 4718 & 279 & 615 & 0 & 198 & 124 \\
\hline $10 \mathrm{H}-1,108.0-109.0$ & 84.38 & 202 & 343 & 254 & 15 & 4490 & 200 & 677 & 0 & 194 & 0 \\
\hline $11 \mathrm{H}-1,83.0-84.0$ & 93.63 & 210 & 454 & 335 & 5 & 4640 & 261 & 702 & 0 & 239 & 0 \\
\hline $12 \mathrm{H}-1,90.0-91.0$ & 103.2 & 210 & 363 & 291 & 33 & 4079 & 180 & 485 & 0 & 286 & 90 \\
\hline $14 \mathrm{H}-1,78.0-79.0$ & 122.08 & 79 & 255 & 99 & 139 & 2344 & 124 & 361 & 0 & 409 & 0 \\
\hline $15 \mathrm{H}-1,86.0-87.0$ & 131.66 & 110 & 143 & 140 & 39 & 3095 & 150 & 523 & 0 & 267 & 68 \\
\hline $16 \mathrm{H}-1,96.0-97.0$ & 141.26 & 150 & 232 & 150 & 79 & 3021 & 130 & 487 & 0 & 337 & 75 \\
\hline $17 \mathrm{H}-1,74.0-75.0$ & 150.54 & 123 & 190 & 166 & 121 & 2599 & 130 & 368 & 0 & 450 & 106 \\
\hline $18 \mathrm{H}-1,86.0-87.0$ & 159.96 & 166 & 148 & 136 & 55 & 3416 & 150 & 404 & 0 & 358 & 93 \\
\hline $19 \mathrm{H}-1,88.0-89.0$ & 169.48 & 212 & 260 & 190 & 48 & 3721 & & 462 & 0 & 284 & 78 \\
\hline $20 \mathrm{H}-1,104.0-105.0$ & 179.14 & 143 & 123 & 138 & 90 & 2735 & & 504 & 0 & 306 & 81 \\
\hline $21 \mathrm{H}-1,87.0-88.0$ & 188.47 & 111 & 151 & 122 & 153 & 2485 & 129 & 356 & 0 & 340 & 103 \\
\hline $22 \mathrm{H}-1,84.0-85.0$ & 197.94 & 160 & 195 & 193 & 174 & 2342 & 91 & 424 & 0 & 389 & 86 \\
\hline
\end{tabular}


Table T4. Datum table, Site U1423.

\begin{tabular}{|c|c|c|c|c|c|c|c|c|c|c|c|c|}
\hline \multicolumn{2}{|c|}{ Core, section, interval $(\mathrm{cm})$} & \multirow{2}{*}{$\begin{array}{l}\text { Event } \\
\text { type }\end{array}$} & \multirow[b]{2}{*}{ Bioevents and epoch boundaries } & \multirow{2}{*}{$\begin{array}{l}\text { Age } \\
\text { (Ma) }\end{array}$} & \multicolumn{4}{|c|}{ Depth CSF-A (m) } & \multicolumn{4}{|c|}{ Depth CCSF-A (m) } \\
\hline Top & Bottom & & & & Top & Bottom & Midpoint & \pm & Top & Bottom & Midpoint & \pm \\
\hline \multicolumn{13}{|c|}{ 346-U1423A- 346-U1423A- } \\
\hline NA & $1 \mathrm{H}-\mathrm{CC}$ & $\mathrm{R}$ & LO Lychnocanoma sakaii & 0.05 & 0 & 7.22 & 3.61 & 3.61 & 0 & 7.22 & 3.61 & 3.61 \\
\hline $1 \mathrm{H}-\mathrm{CC}$ & $2 \mathrm{H}-\mathrm{CC}$ & $\mathrm{R}$ & LO Amphimelissa setosa & 0.08 & 7.22 & 16.97 & 12.10 & 4.88 & 7.22 & 17.44 & 12.33 & 5.11 \\
\hline $2 \mathrm{H}-\mathrm{CC}$ & $3 \mathrm{H}-\mathrm{CC}$ & $\mathrm{R}$ & LO Spongodiscus sp. & 0.29 & 16.97 & 26.58 & 21.78 & 4.81 & 17.44 & 27.44 & 22.44 & 5.00 \\
\hline $3 \mathrm{H}-\mathrm{CC}$ & $4 \mathrm{H}-\mathrm{CC}$ & D & LO Proboscia curvirostris & 0.3 & 26.58 & 36.07 & 31.33 & 4.75 & 27.44 & 37.61 & 32.52 & 5.08 \\
\hline $4 \mathrm{H}-\mathrm{CC}$ & $5 \mathrm{H}-1 \mathrm{~W}, 113-114$ & $\mathrm{CN}$ & LO Pseudoemiliania lacunosa & 0.44 & 36.07 & 36.93 & 36.50 & 0.43 & 37.61 & 39.07 & 38.34 & 0.73 \\
\hline $4 \mathrm{H}-\mathrm{CC}$ & $5 \mathrm{H}-4 \mathrm{~W}, 77-78$ & PF & LO Neogloboquadrina kagaensis group & 0.70 & 36.07 & 41.07 & 38.57 & 2.50 & 37.61 & 43.21 & 40.41 & 2.80 \\
\hline $5 \mathrm{H}-\mathrm{CC}$ & $6 \mathrm{H}-\mathrm{CC}$ & $\mathrm{D}$ & LO Actinocyclus oculatus & 1.0 & 45.38 & 54.91 & 50.15 & 4.77 & 47.52 & 57.30 & 52.41 & 4.89 \\
\hline $6 \mathrm{H}-\mathrm{CC}$ & $8 \mathrm{H}-\mathrm{CC}$ & $\mathrm{CN}$ & $\mathrm{Br}$ Gephyrocapsa $>4 \mu \mathrm{m}$ & 1.04 & 54.91 & 74.14 & 64.53 & 9.61 & 57.30 & 77.74 & 67.52 & 10.22 \\
\hline $6 \mathrm{H}-\mathrm{CC}$ & $9 \mathrm{H}-2 \mathrm{~W}, 75-76$ & $\mathrm{CN}$ & LO Calcidiscus macintyrei & 1.6 & 54.91 & 76.05 & 65.48 & 10.57 & 57.30 & 79.89 & 68.59 & 11.29 \\
\hline 7H-CC & $8 \mathrm{H}-\mathrm{CC}$ & D & LO Neodenticula koizumii & 2.0 & 64.64 & 74.14 & 69.39 & 4.75 & 67.64 & 77.74 & 72.69 & 5.05 \\
\hline $8 \mathrm{H}-\mathrm{CC}$ & $10 \mathrm{H}-\mathrm{CC}$ & $\mathrm{R}$ & LO Axoprunum acquilonium & $1.2-1.7$ & 74.14 & 93.17 & 83.66 & 9.52 & 77.74 & 97.36 & 87.55 & 9.81 \\
\hline \multicolumn{4}{|c|}{ Pliocene/Pleistocene boundary } & 2.59 & & & & & & & & \\
\hline $12 \mathrm{H}-\mathrm{CC}$ & $13 \mathrm{H}-\mathrm{CC}$ & D & LO Neodenticula kamtschatica & $2.6-2.7$ & 112.06 & 121.70 & 116.88 & 4.82 & 116.07 & 126.60 & 121.33 & 5.27 \\
\hline $12 \mathrm{H}-\mathrm{CC}$ & $13 \mathrm{H}-\mathrm{CC}$ & $\mathrm{R}$ & FO Cycladophora davisiana & 2.7 & 112.06 & 121.70 & 116.88 & 4.82 & 116.07 & 126.60 & 121.33 & 5.27 \\
\hline $14 \mathrm{H}-\mathrm{CC}$ & $15 \mathrm{H}-\mathrm{CC}$ & D & FO Neodenticula koizumii & $3.4-3.9$ & 131.19 & 140.51 & 135.85 & 4.66 & 136.17 & 145.95 & 141.06 & 4.89 \\
\hline $18 \mathrm{H}-\mathrm{CC}$ & $19 \mathrm{H}-\mathrm{CC}$ & $\mathrm{R}$ & FO Hexacontium parviakitaensis & $3.9-4.3$ & 168.88 & 178.34 & 173.61 & 4.73 & 175.71 & 185.82 & 180.77 & 5.06 \\
\hline $19 \mathrm{H}-\mathrm{CC}$ & $20 \mathrm{H}-\mathrm{CC}$ & $\mathrm{R}$ & LO Dictyophimus bullatus & $3.9-4.3$ & 178.34 & 187.73 & 183.04 & 4.69 & 185.82 & 195.35 & 190.58 & 4.76 \\
\hline $19 \mathrm{H}-\mathrm{CC}$ & $20 \mathrm{H}-\mathrm{CC}$ & $\mathrm{R}$ & RD Siphocampe arachnea group & 4.46 & 178.34 & 187.73 & 183.04 & 4.69 & 185.82 & 195.35 & 190.59 & 4.76 \\
\hline $21 \mathrm{H}-\mathrm{CC}$ & $22 \mathrm{H}-\mathrm{CC}$ & $\mathrm{R}$ & FO Dictyophimus bullatus & 4.4 & 197.22 & 206.97 & 202.10 & 4.88 & 205.13 & 215.06 & 210.10 & 4.96 \\
\hline \multicolumn{13}{|c|}{ 346-U1423B- 346-U1423B- } \\
\hline $2 \mathrm{H}-4 \mathrm{~W}, 69-70$ & o $4 \mathrm{H}-4 \mathrm{~W}, 53-54$ & $\mathrm{CN}$ & FO Emiliania huxleyi & 0.29 & 9.29 & 28.10 & 18.70 & 9.41 & 9.73 & 29.26 & 19.49 & 9.77 \\
\hline $5 \mathrm{H}-7 \mathrm{~W}, 32-33$ & $36 \mathrm{H}-3 \mathrm{~W}, 132-133$ & $\mathrm{PF}$ & LO Neogloboquadrina kagaensis group & 0.70 & 41.92 & 46.42 & 44.17 & 2.25 & 43.35 & 48.56 & 45.95 & 2.60 \\
\hline $15 \mathrm{H}-\mathrm{CC}$ & $16 \mathrm{H}-\mathrm{CC}$ & D & FO Neodenticula koizumii & $3.4-3.9$ & 132.8 & 142.40 & 137.60 & 4.80 & 138.69 & 147.96 & 143.32 & 4.63 \\
\hline $22 \mathrm{H}-\mathrm{CC}$ & $23 \mathrm{H}-\mathrm{CC}$ & $\mathrm{R}$ & FO Dictyophimus bullatus & 4.4 & 192.33 & 201.90 & 197.12 & 4.79 & 199.54 & 209.35 & 204.44 & 4.90 \\
\hline $25 \mathrm{H}-\mathrm{CC}$ & $26 \mathrm{H}-\mathrm{CC}$ & $\mathrm{R}$ & RI Siphocampe arachnea group & 4.71 & 220.78 & 230.10 & 225.44 & 4.66 & 228.40 & 237.72 & 233.06 & 4.66 \\
\hline $27 \mathrm{H}-\mathrm{CC}$ & $28 \mathrm{H}-\mathrm{CC}$ & D & LO Thalassiosira jacksonii & 4.81 & 239.95 & 249.47 & 244.71 & 4.76 & 247.57 & 257.09 & 252.33 & 4.76 \\
\hline
\end{tabular}

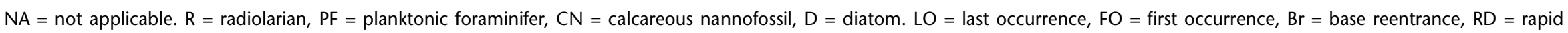
decrease, $\mathrm{RI}=$ rapid increase. 
Table T5. Preservation and estimated abundance of calcareous nannofossils, Site U1423. (Continued on next page.)

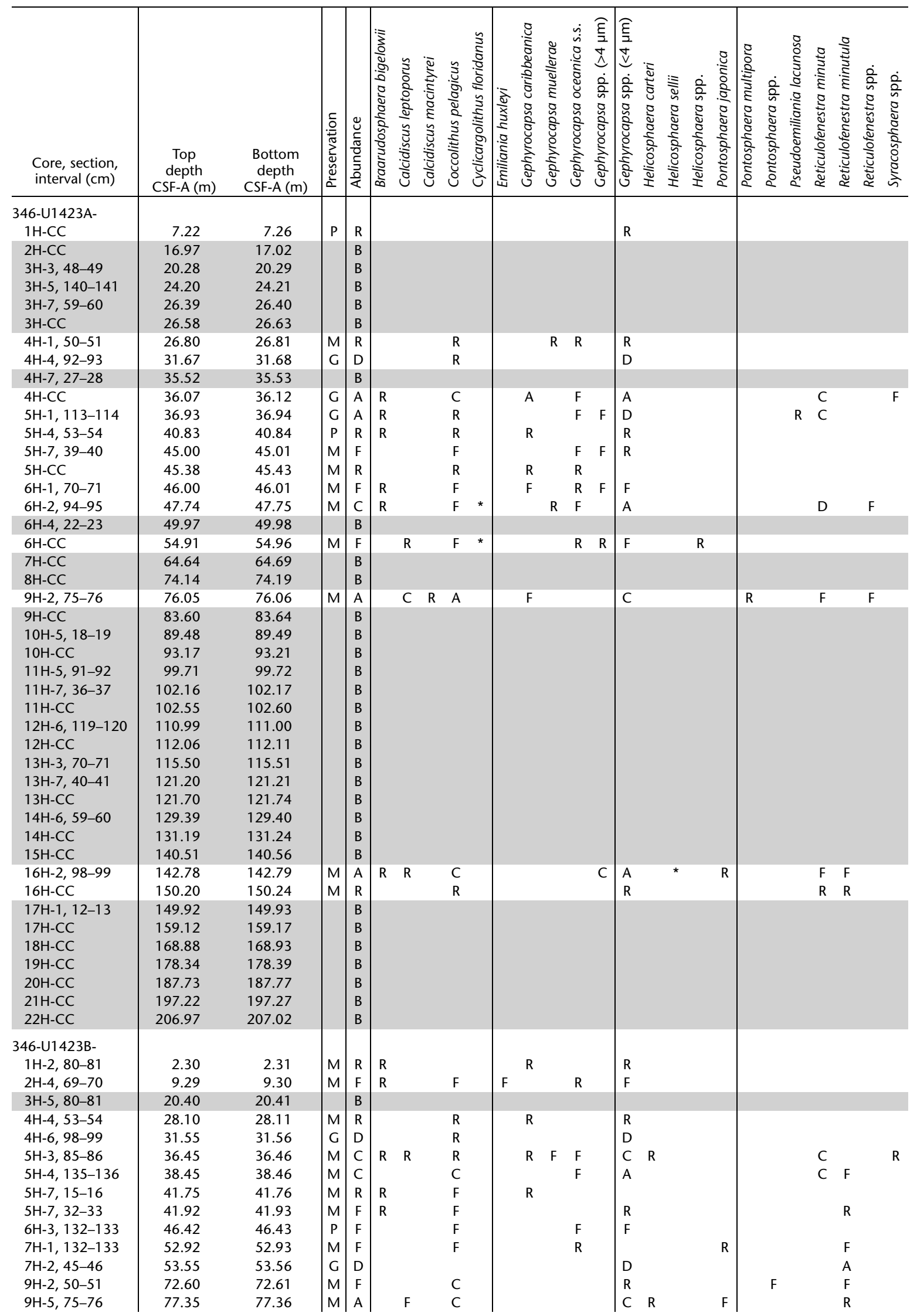


Table T5 (continued).

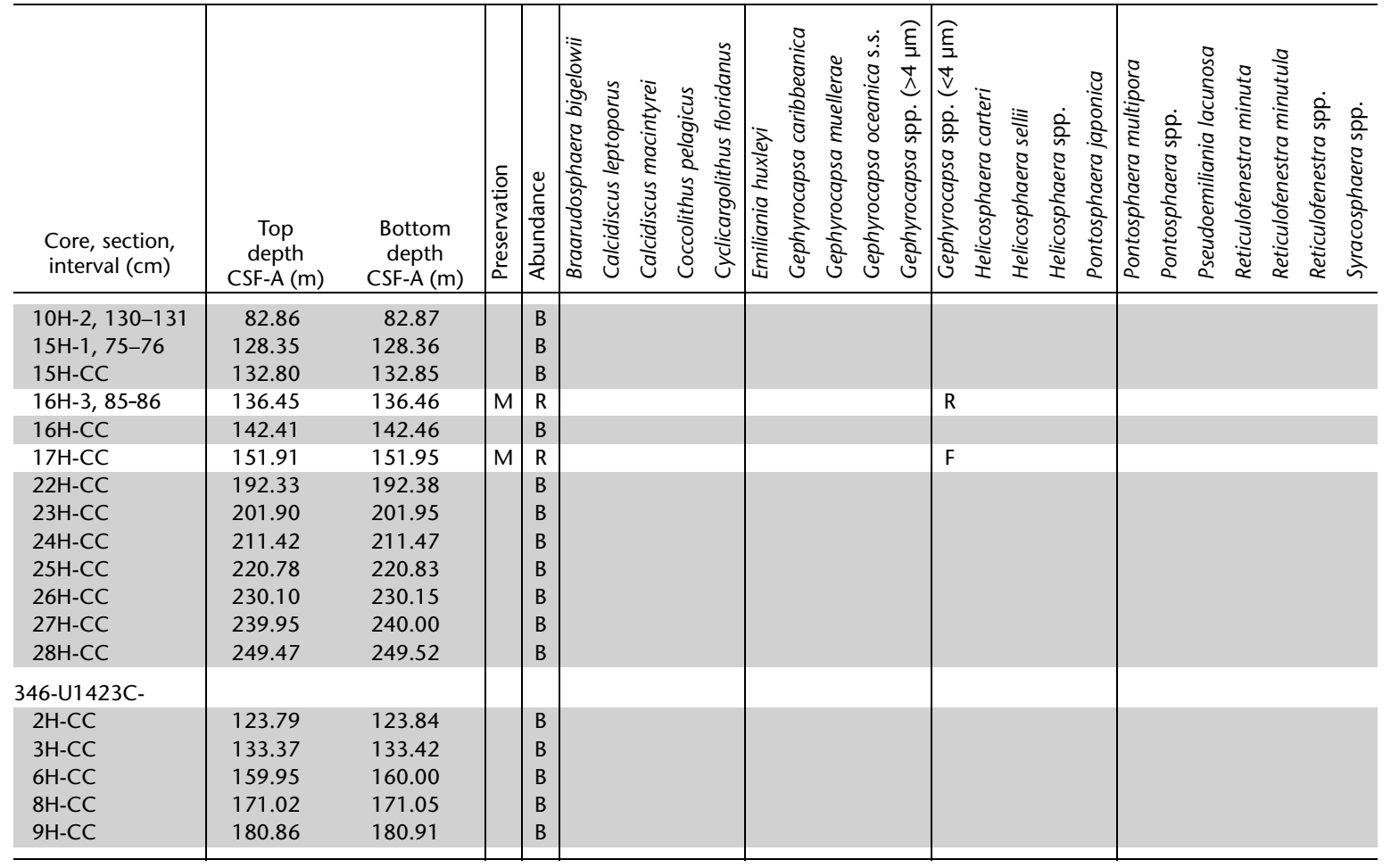

${ }^{*}=$ indicates species not in situ. Preservation: $\mathrm{G}=$ good, $\mathrm{M}=$ moderate, $\mathrm{P}=$ poor. Abundance: $\mathrm{D}=$ dominant, $\mathrm{A}=$ abundant, $\mathrm{C}=\mathrm{common}, \mathrm{F}=$ few, $R=$ rare, $B=$ barren. Shaded intervals = barren. 
Table T6. Preservation and estimated abundance of radiolarians, Holes U1423A and U1423B.

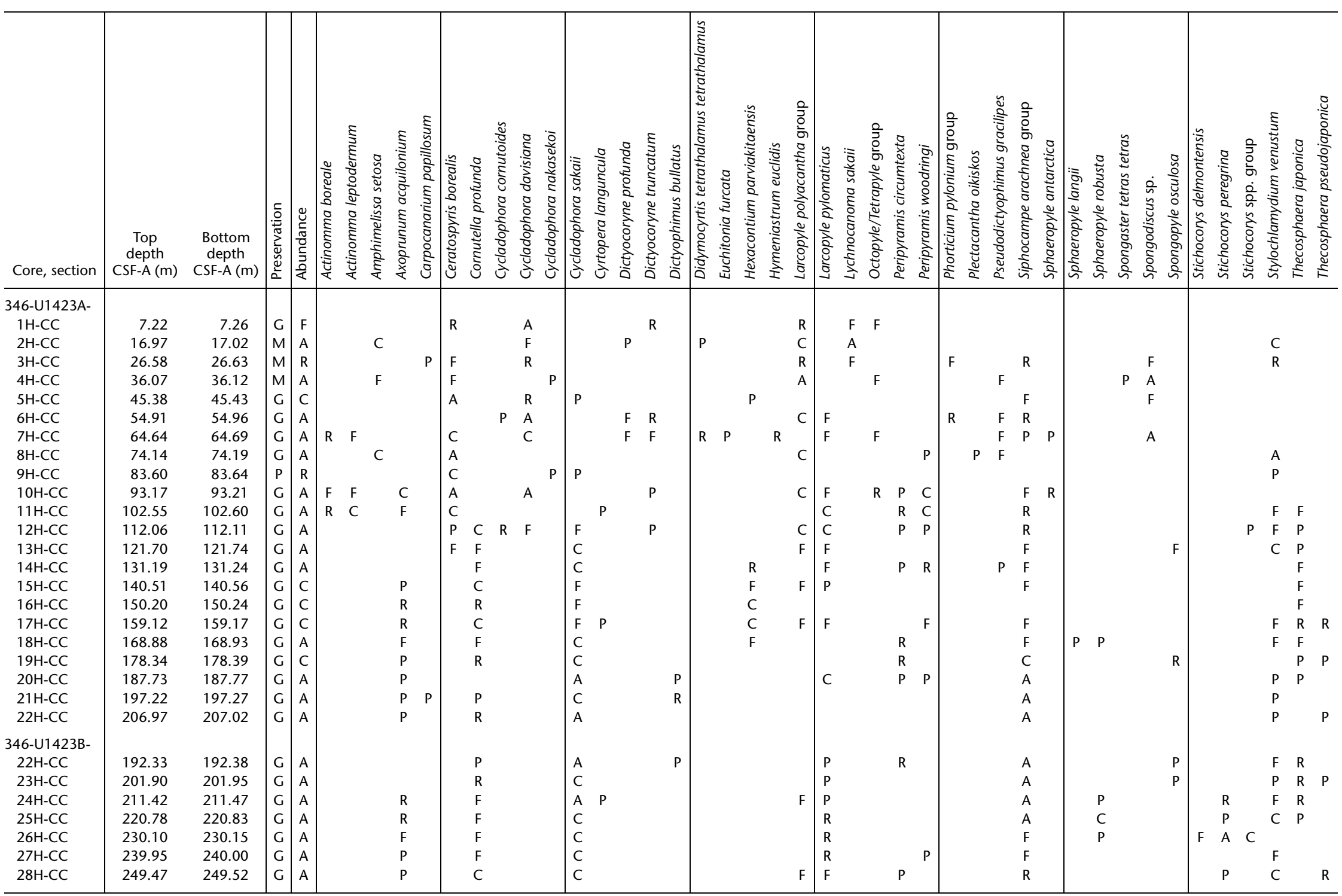

Preservation: $\mathrm{G}=$ good, $\mathrm{M}=$ moderate, $\mathrm{P}=$ poor. Abundance: $\mathrm{A}=$ abundant, $\mathrm{C}=$ common, $\mathrm{F}=$ few, $\mathrm{R}=$ rare, $\mathrm{P}=$ present. 
Table T7. Preservation and estimated abundance of diatoms, Holes U1423A and U1423B.

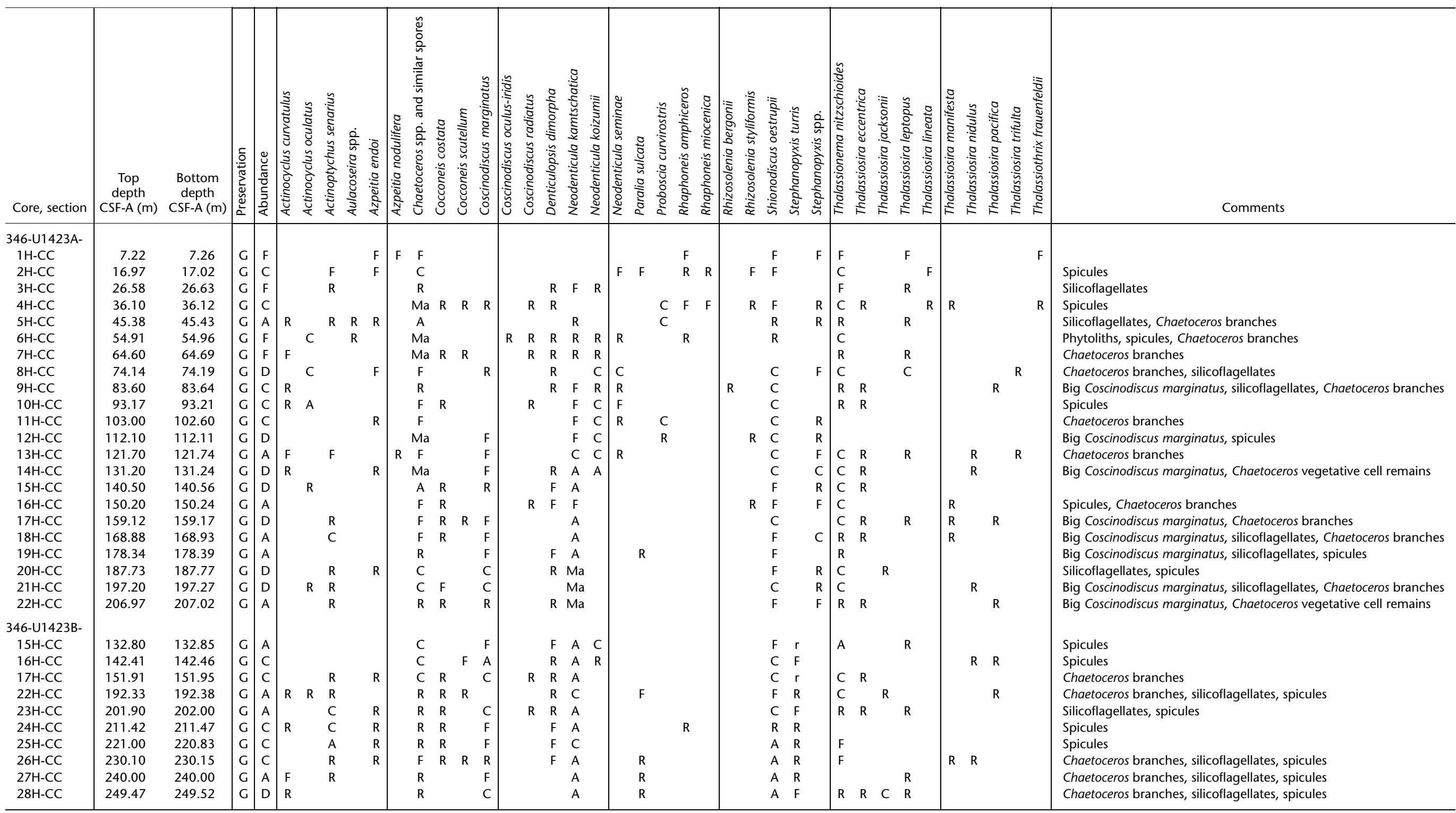

Preservation: $\mathrm{G}=$ good. Abundance: $\mathrm{Ma}=$ massive, $\mathrm{D}=$ dominant $\mathrm{A}=$ abundant, $\mathrm{C}=$ common, $\mathrm{F}=$ few, $\mathrm{R}=$ rare. 
Table T8. Preservation and estimated abundance of planktonic foraminifers, Holes U1423A and U1423B. (Continued on next page.)

\begin{tabular}{|c|c|c|c|c|c|c|c|c|c|c|c|c|c|c|c|}
\hline $\begin{array}{l}\text { Core, section, } \\
\text { interval }(\mathrm{cm})\end{array}$ & $\begin{array}{c}\text { Top } \\
\text { depth } \\
\text { CSF-A (m) }\end{array}$ & $\begin{array}{c}\text { Bottom } \\
\text { depth } \\
\text { CSF-A (m) }\end{array}$ & 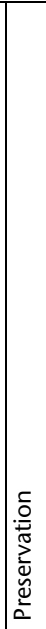 & 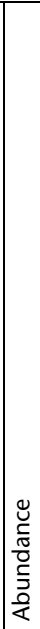 & 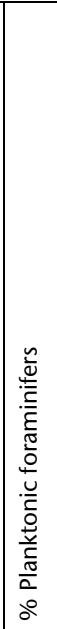 & 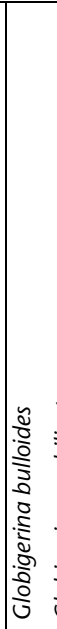 & 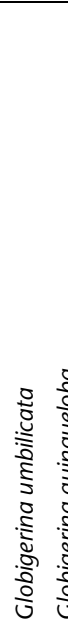 & 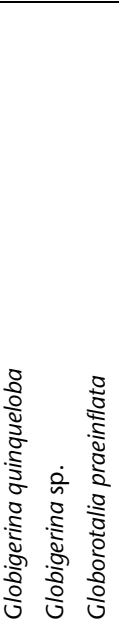 & 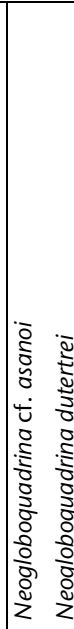 & 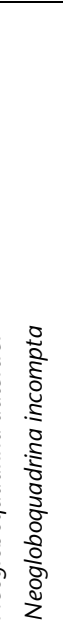 & 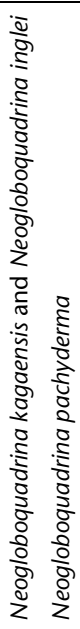 & 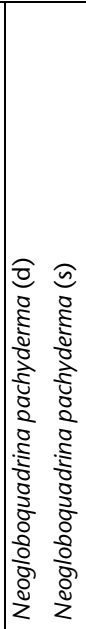 & 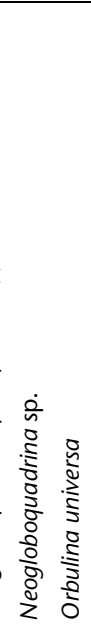 & 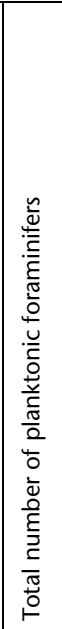 & 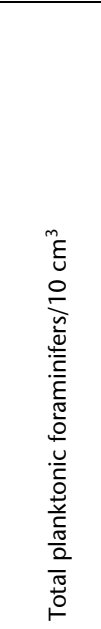 \\
\hline \multicolumn{16}{|l|}{ 346-U1423A- } \\
\hline $1 \mathrm{H}-\mathrm{CC}$ & 7.22 & 7.26 & G & A & 99 & 25 & 3 & & 2 & 2 & & 268 & & 100 & 33.3 \\
\hline $2 \mathrm{H}-\mathrm{CC}$ & 16.97 & 17.02 & & A & 20 & 14 & & & & & & 26 & & 22 & 7.33 \\
\hline $3 \mathrm{H}-\mathrm{CC}$ & 26.58 & 26.63 & & A & 99 & 30 & & & & 2 & & 167 & & 100 & 33.3 \\
\hline $4 \mathrm{H}-\mathrm{CC}$ & 36.07 & 36.12 & G & A & 95 & 33 & & & & & & 72 & & 105 & 35 \\
\hline $5 \mathrm{H}-4,77-78$ & 41.07 & 41.08 & $M$ & A & 100 & 38 & 9 & 41 & 2 & 2 & 4 & 346 & & 107 & 1070 \\
\hline $5 \mathrm{H}-\mathrm{CC}$ & 45.38 & 45.43 & $P$ & A & 88 & 22 & 1 & & & & & 176 & & 100 & 33.3 \\
\hline $6 \mathrm{H}-\mathrm{CC}$ & 54.91 & 54.96 & G & A & 88 & 49 & 6 & & 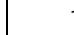 & 1 & 8 & 227 & 71 & 94 & 31.3 \\
\hline 7H-CC & 64.64 & 64.69 & M & $\mathrm{R}$ & 80 & 12 & 3 & & & & & 4 & & 19 & 6.33 \\
\hline $8 \mathrm{H}-\mathrm{CC}$ & 74.14 & 74.19 & $M$ & $\mathrm{R}$ & 100 & 3 & & & & & & 2 & & 5 & 1.67 \\
\hline 9H-CC & 83.60 & 83.64 & & B & & & & & & & & & & 0 & 0 \\
\hline $10 \mathrm{H}-5,18-19$ & 89.48 & 89.49 & & B & & & & & & & & & & 0 & 0 \\
\hline $10 \mathrm{H}-\mathrm{CC}$ & 93.17 & 93.21 & & B & & & & & & & & & & 0 & 0 \\
\hline $11 \mathrm{H}-5,91-92$ & 99.71 & 99.72 & & B & & & & & & & & & & 0 & 0 \\
\hline $11 \mathrm{H}-7,36-37$ & 102.16 & 102.17 & $\mathrm{P}$ & $\mathrm{R}$ & & & & & & & & & 1 & 1 & 10 \\
\hline $11 \mathrm{H}-\mathrm{CC}$ & 102.55 & 102.60 & & B & & & & & & & & & & 0 & 0 \\
\hline $12 \mathrm{H}-6,119-120$ & 110.99 & 111.00 & & B & & & & & & & & & & 0 & 0 \\
\hline $12 \mathrm{H}-\mathrm{CC}$ & 112.06 & 112.11 & & B & & & & & & & & & & 0 & 0 \\
\hline $13 \mathrm{H}-3,70-71$ & 115.50 & 115.51 & & B & & & & & & & & & & 0 & 0 \\
\hline $13 \mathrm{H}-\mathrm{CC}$ & 121.70 & 121.74 & & B & & & & & & & & & & 0 & 0 \\
\hline $14 \mathrm{H}-\mathrm{CC}$ & 131.19 & 131.24 & & B & & & & & & & & & & 0 & 0 \\
\hline $15 \mathrm{H}-\mathrm{CC}$ & 140.51 & 140.56 & & B & & & & & & & & & & 0 & 0 \\
\hline $16 \mathrm{H}-2,98-99$ & 142.78 & 142.79 & M & $\mathrm{R}$ & 100 & 6 & & 7 & 1 & 1 & 11 & 41 & & 22 & 220 \\
\hline $16 \mathrm{H}-\mathrm{CC}$ & 150.20 & 150.24 & G & A & 70 & 25 & 30 & 3 & $101 \varepsilon$ & & 37 & 20 & 3 & 146 & 48.7 \\
\hline $17 \mathrm{H}-1,20-21$ & 150.00 & 150.01 & & B & & & & & & & & & & 0 & 0 \\
\hline $18 \mathrm{H}-\mathrm{CC}$ & 168.88 & 168.93 & & B & & & & & & & & & & 0 & 0 \\
\hline $19 \mathrm{H}-\mathrm{CC}$ & 178.34 & 178.39 & & B & & & & & & & & & & 0 & 0 \\
\hline $2 \mathrm{OH}-\mathrm{CC}$ & 187.73 & 187.77 & & B & & & & & & & & & & 0 & 0 \\
\hline $21 \mathrm{H}-\mathrm{CC}$ & 197.22 & 197.27 & & B & & & & & & & & & & 0 & 0 \\
\hline $22 \mathrm{H}-\mathrm{CC}$ & 206.97 & 207.02 & G & $\mathrm{R}$ & 18 & 3 & & & & & & 1 & & 4 & 1.33 \\
\hline \multicolumn{16}{|l|}{ 346-U1423B- } \\
\hline $4 \mathrm{H}-4,53-54$ & 28.10 & 28.11 & $M$ & D & 100 & 21 & & & & & & 177 & & 99 & 990 \\
\hline $4 \mathrm{H}-6,64-65$ & 31.21 & 31.22 & $M$ & D & 90 & 30 & 1 & 2 & & 2 & & 175 & & 111 & 1110 \\
\hline $4 \mathrm{H}-6,98-99$ & 31.55 & 31.56 & $M$ & D & 100 & 20 & 51 & 17 & . & 12 & & 253 & & 100 & 1000 \\
\hline $5 \mathrm{H}-3,85-86$ & 36.45 & 36.46 & $M$ & D & 100 & 38 & 3 & 4 & 2 & 2 & & 55 & & 102 & 1020 \\
\hline $5 \mathrm{H}-4,135-136$ & 38.45 & 38.46 & G & D & 100 & 1 & & & & 1 & & 197 & & 100 & 1000 \\
\hline $5 \mathrm{H}-7,32-33$ & 41.92 & 41.93 & G & D & 100 & 65 & 1 & 1 & & 1 & & 128 & & 97 & 970 \\
\hline $6 \mathrm{H}-3,132-133$ & 46.42 & 46.43 & G & D & 100 & 48 & & & 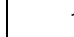 & 11 & 1 & 36 & & 87 & 870 \\
\hline $6 \mathrm{H}-5,48-49$ & 48.58 & 48.59 & G & D & 99 & 30 & 2 & 3 & & & 2 & 355 & & 95 & 950 \\
\hline 7H-1, 132-133 & 52.92 & 52.93 & G & D & 100 & 43 & 6 & & & & 5 & 244 & & 100 & 1000 \\
\hline $7 \mathrm{H}-2,45-46$ & 53.55 & 53.56 & G & D & 100 & 40 & 6 & 5 & 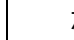 & 7 & 20 & 223 & 31 & 104 & 1040 \\
\hline $8 \mathrm{H}-2,118-119$ & 63.78 & 63.79 & $M$ & D & 100 & 40 & 3 & & & & 6 & 346 & & 98 & 980 \\
\hline $8 \mathrm{H}-6,43-44$ & 69.03 & 69.04 & G & D & 88 & 49 & 4 & & & & 5 & 637 & & 101 & 1010 \\
\hline $9 \mathrm{H}-2,50-51$ & 72.6 & 72.61 & $P$ & D & 95 & 51 & 1 & 3 & 32 & 2 & 21 & 52 & & 88 & 880 \\
\hline $9 \mathrm{H}-5,75-76$ & 77.35 & 77.36 & $P$ & $F$ & 100 & 2 & & & & & & 2 & & 4 & 40 \\
\hline $10 \mathrm{H}-2,130-131$ & 82.86 & 82.87 & & B & & & & & & & & & & 0 & 0 \\
\hline $15 \mathrm{H}-\mathrm{CC}$ & 132.80 & 132.85 & $M$ & A & 81 & 32 & 7 & $\begin{array}{ll}1 & 19\end{array}$ & 4 & & & 613 & & 82 & 27.3 \\
\hline $16 \mathrm{H}-\mathrm{CC}$ & 142.41 & 142.46 & & B & & & & & & & & & & 0 & 0 \\
\hline $17 \mathrm{H}-\mathrm{CC}$ & 151.91 & 151.95 & & B & & & & & & & & & & 0 & 0 \\
\hline
\end{tabular}


Table T8 (continued).

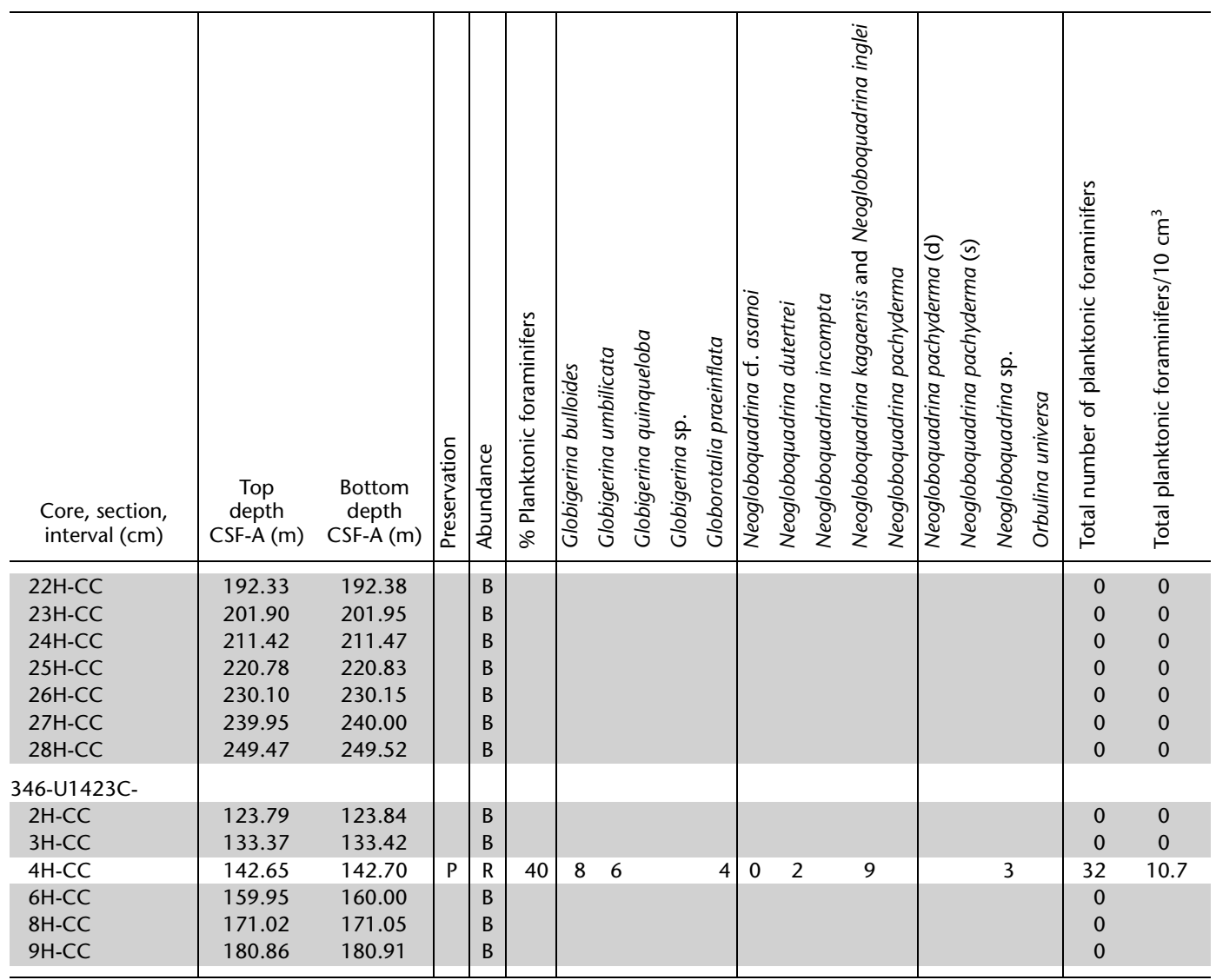

Numbers of specimens in core catcher samples refer to $\sim 30 \mathrm{~cm}^{3}$, whereas numbers in core samples refer to $1 \mathrm{~cm}^{3}$. Preservation: $\mathrm{G}=\mathrm{good}, \mathrm{M}=$ moderate, $\mathrm{P}=$ poor. Abundance: $\mathrm{D}=$ dominant, $\mathrm{A}=$ abundant, $\mathrm{F}=\mathrm{few}, \mathrm{R}=$ rare, $\mathrm{B}=$ barren. Shaded intervals $=$ barren.

Table T9. Benthic foraminifers, Site U1423. This table is available in an oversized format. 
Table T10. Calcium carbonate, total carbon (TC), total organic carbon (TOC), and total nitrogen (TN) contents on interstitial water squeeze cake sediment samples, Site U1423.

\begin{tabular}{|c|c|c|c|c|c|}
\hline $\begin{array}{l}\text { Core, section, } \\
\text { interval }(\mathrm{cm})\end{array}$ & $\begin{array}{l}\text { Top depth } \\
\text { CSF-A (m) }\end{array}$ & $\begin{array}{l}\text { Calcium } \\
\text { carbonate } \\
\text { (wt\%) }\end{array}$ & $\begin{array}{c}\mathrm{TC} \\
\text { (wt\%) }\end{array}$ & $\begin{array}{l}\text { TOC } \\
\text { (wt\%) }\end{array}$ & $\begin{array}{c}\mathrm{TN} \\
(\mathrm{wt} \%)\end{array}$ \\
\hline \multicolumn{6}{|l|}{ 346-U1423A- } \\
\hline $1 \mathrm{H}-1,145-150$ & 1.45 & 1.14 & 2.25 & 2.11 & 0.31 \\
\hline $1 \mathrm{H}-4,145-150$ & 5.95 & 0.50 & 0.40 & 0.34 & 0.15 \\
\hline $2 \mathrm{H}-1,145-150$ & 8.75 & 0.86 & 0.27 & 0.17 & 0.15 \\
\hline $2 \mathrm{H}-4,145-150$ & 13.25 & 0.76 & 1.00 & 0.91 & 0.22 \\
\hline $3 \mathrm{H}-1,145-150$ & 18.25 & 0.20 & 1.18 & 1.15 & 0.22 \\
\hline $3 \mathrm{H}-4,145-150$ & 22.75 & 0.24 & 0.42 & 0.39 & 0.14 \\
\hline $4 \mathrm{H}-1,140-145$ & 27.70 & 0.17 & 2.35 & 2.33 & 0.31 \\
\hline $4 \mathrm{H}-4,145-150$ & 32.20 & 0.39 & 0.75 & 0.71 & 0.19 \\
\hline $5 \mathrm{H}-1,145-150$ & 37.25 & 1.14 & 2.55 & 2.42 & 0.31 \\
\hline $5 \mathrm{H}-4,145-150$ & 41.75 & 14.27 & 2.79 & 1.08 & 0.19 \\
\hline $6 \mathrm{H}-1,145-150$ & 46.75 & 0.42 & 0.89 & 0.84 & 0.21 \\
\hline $6 \mathrm{H}-4,145-150$ & 51.20 & 0.65 & 0.58 & 0.50 & 0.16 \\
\hline $7 \mathrm{H}-1,145-150$ & 56.25 & 0.88 & 0.55 & 0.44 & 0.18 \\
\hline $7 \mathrm{H}-4,145-150$ & 60.75 & 0.25 & 0.46 & 0.43 & 0.17 \\
\hline $8 \mathrm{H}-1,145-150$ & 65.75 & 0.26 & 1.84 & 1.81 & 0.26 \\
\hline $8 \mathrm{H}-4,145-150$ & 70.25 & 0.94 & 0.39 & 0.27 & 0.13 \\
\hline $9 \mathrm{H}-1,145-150$ & 75.25 & 0.32 & 2.13 & 2.09 & 0.26 \\
\hline $9 \mathrm{H}-4,145-150$ & 79.75 & 0.40 & 0.46 & 0.41 & 0.16 \\
\hline $10 \mathrm{H}-1,145-150$ & 84.75 & 0.29 & 0.27 & 0.23 & 0.15 \\
\hline $10 \mathrm{H}-4,145-150$ & 89.25 & 0.26 & 0.39 & 0.36 & 0.15 \\
\hline $11 \mathrm{H}-1,145-150$ & 94.25 & 0.33 & 0.47 & 0.43 & 0.17 \\
\hline $11 \mathrm{H}-4,145-150$ & 98.75 & 0.21 & 0.74 & 0.71 & 0.18 \\
\hline $12 \mathrm{H}-1,145-150$ & 103.75 & 0.32 & 1.31 & 1.27 & 0.22 \\
\hline $12 \mathrm{H}-4,145-150$ & 108.25 & 0.31 & 0.48 & 0.44 & 0.17 \\
\hline $13 \mathrm{H}-1,145-150$ & 113.25 & 0.26 & & & \\
\hline $13 \mathrm{H}-4,145-150$ & 117.75 & 0.27 & 0.56 & 0.52 & 0.17 \\
\hline $14 \mathrm{H}-1,145-150$ & 122.75 & 0.26 & 0.44 & 0.41 & 0.15 \\
\hline $15 \mathrm{H}-1,145-150$ & 132.25 & 0.32 & 0.53 & 0.49 & 0.18 \\
\hline $16 \mathrm{H}-1,145-150$ & 141.75 & 0.26 & 0.72 & 0.69 & 0.19 \\
\hline $17 \mathrm{H}-1,145-150$ & 151.25 & 0.27 & & & \\
\hline $18 \mathrm{H}-1,145-150$ & 160.55 & 0.31 & 0.51 & 0.47 & 0.17 \\
\hline $19 \mathrm{H}-1,145-150$ & 170.05 & 0.27 & 0.51 & 0.48 & 0.16 \\
\hline $20 \mathrm{H}-1,145-150$ & 179.55 & 0.27 & 0.41 & 0.38 & 0.14 \\
\hline $21 \mathrm{H}-1,145-150$ & 189.05 & 0.41 & 0.55 & 0.50 & 0.14 \\
\hline $22 \mathrm{H}-1,145-150$ & 198.55 & 0.27 & 0.48 & 0.45 & 0.15 \\
\hline \multicolumn{6}{|l|}{ 346-U1423B- } \\
\hline $23 \mathrm{H}-3,145-150$ & 196.55 & 0.21 & 0.65 & 0.63 & 0.17 \\
\hline $24 \mathrm{H}-3,145-150$ & 206.05 & 0.29 & 0.41 & 0.38 & 0.15 \\
\hline $25 \mathrm{H}-3,145-150$ & 215.55 & 0.27 & 0.49 & 0.45 & 0.16 \\
\hline $26 \mathrm{H}-3,145-150$ & 225.05 & 0.23 & 0.61 & 0.58 & 0.16 \\
\hline $27 \mathrm{H}-3,145-150$ & 234.55 & 0.28 & 0.52 & 0.49 & 0.16 \\
\hline $28 \mathrm{H}-3,145-150$ & 244.05 & 0.12 & & & \\
\hline
\end{tabular}

Blank cells $=$ not analyzed. 
Table T11. Interstitial water geochemistry, Site U1423.

\begin{tabular}{|c|c|c|c|c|c|c|c|c|c|c|c|c|c|c|c|c|c|c|c|c|c|c|c|c|}
\hline $\begin{array}{l}\text { Core, section, } \\
\text { interval }(\mathrm{cm})\end{array}$ & $\begin{array}{l}\text { Top depth } \\
\text { CSF-A (m) }\end{array}$ & $\begin{array}{l}\text { Sample } \\
\text { type }\end{array}$ & $\begin{array}{c}\text { Volume } \\
\text { squeezed } \\
(\mathrm{mLL}\end{array}$ & $\begin{array}{l}\text { Alkalinity } \\
\text { (mM) } \\
\text { Titration }\end{array}$ & $\begin{array}{l}\mathrm{PH} \\
\mathrm{ISE}\end{array}$ & $\begin{array}{l}\text { Salinity } \\
(\%))^{2} \\
\text { Refract }\end{array}$ & $\underset{\substack{C l \\
\text { (mM) } \\
\text { Titration }}}{c}$ & $\begin{array}{c}\mathrm{Cl}^{-} \\
(\mathrm{mM}) \\
\mathrm{IC}\end{array}$ & $\begin{array}{l}\mathrm{SO}_{\mathrm{O}}^{2^{-2}} \\
(\mathrm{mM}) \\
\mathrm{IC}\end{array}$ & $\begin{array}{c}\mathrm{Br} \\
(\mathrm{mM}) \\
\mathrm{IC}\end{array}$ & $\begin{array}{c}\mathrm{Na} \\
(\mathrm{mM}) \\
\mathrm{ICP}\end{array}$ & $\begin{array}{c}\mathrm{Ca} \\
(\mathrm{mM}) \\
\mathrm{ICP}\end{array}$ & $\begin{array}{l}\mathrm{Mg} \\
(\mathrm{mM}) \\
\mathrm{ICP}\end{array}$ & $\begin{array}{c}\mathrm{K} \\
(\mathrm{mM}) \\
\mathrm{ICP}\end{array}$ & $\begin{array}{c}\mathrm{B} \\
(\mu \mathrm{M}) \\
\mathrm{I}(\mathrm{CP})\end{array}$ & $\begin{array}{c}\mathrm{Ba} \\
(\mu \mathrm{M}) \\
\mathrm{CMP}\end{array}$ & $\begin{array}{c}\mathrm{Fe} \\
(\mathrm{MM}) \\
\mathrm{CM}\end{array}$ & $\begin{array}{l}\mathrm{Li} \\
(\mathrm{MM}) \\
\mathrm{ICP}\end{array}$ & $\begin{array}{l}\mathrm{Mn} \\
(\mu \mathrm{MM}) \\
\mathrm{ICP}\end{array}$ & $\begin{array}{c}\mathrm{Si} \\
\text { (uM }) \\
\text { ICP }\end{array}$ & $\begin{array}{c}\mathrm{Sr} \\
\text { (IM) } \\
\mathrm{ICP}\end{array}$ & $\begin{array}{l}\mathrm{NH}_{4}^{+}{ }^{+} \\
\left(\mu M_{0}\right. \\
\text { Spec }\end{array}$ & 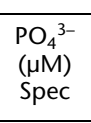 & $\begin{array}{l}\mathrm{H}_{4} \mathrm{SiO}_{4} \\
\mu \mathrm{MM})^{2} \\
\text { Spec }\end{array}$ \\
\hline $\begin{array}{l}346-\cup 1423 A- \\
1 H-10-5\end{array}$ & & & & & & & & & & & & & & & & & & & & & & & & \\
\hline $\begin{array}{l}1 \mathrm{H}-1,0-5 \\
1 \mathrm{H}-1,145-150\end{array}$ & $\begin{array}{l}0.00 \\
1.45\end{array}$ & $\begin{array}{l}\text { ML } \\
\text { IW-Sq }\end{array}$ & $\begin{array}{l}50 \\
50\end{array}$ & $\begin{array}{l}2.4 \\
6.1\end{array}$ & $\begin{array}{l}7.6 \\
7.5\end{array}$ & $\begin{array}{l}\begin{array}{l}35 \\
35\end{array} \\
3\end{array}$ & $\begin{array}{l}541 \\
548\end{array}$ & $\begin{array}{l}564 \\
564\end{array}$ & $\begin{array}{l}28.6 \\
25.8\end{array}$ & $\begin{array}{l}0.86 \\
0.87\end{array}$ & $\begin{array}{l}468 \\
472\end{array}$ & $\begin{array}{l}10.2 \\
9.8\end{array}$ & $\begin{array}{l}51.7 \\
49.8\end{array}$ & $\begin{array}{l}10.1 \\
11.7\end{array}$ & $\begin{array}{l}\begin{array}{l}422 \\
583\end{array} \\
5\end{array}$ & ${ }^{B D}{ }_{6}$ & $\begin{array}{l}\mathrm{BD} \\
\mathrm{BD}\end{array}$ & ${ }_{23}^{22}$ & $\begin{array}{l}\mathrm{BD} \\
123\end{array}$ & $\begin{array}{l}112 \\
627\end{array}$ & $\begin{array}{l}87 \\
93\end{array}$ & $\begin{array}{r}93 \\
315\end{array}$ & $\begin{array}{r}1.4 \\
54.4\end{array}$ & $\begin{array}{r}98 \\
566\end{array}$ \\
\hline $1 \mathrm{H}-4,145-150$ & 5.95 & IW-Sq & 42 & 12.0 & 7.7 & 35 & 537 & 562 & 19.7 & 0.87 & 461 & 8.5 & 47.1 & 11.8 & 556 & 15 & 4.8 & 18 & 23 & 516 & 87 & 771 & 79.3 & 500 \\
\hline $2 \mathrm{H}-1,145-150$ & $\begin{array}{r}8.75 \\
1325\end{array}$ & IW-Sq & 40 & 15.5 & 7.7 & 34 & 535 & 560 & 16.2 & 0.87 & 458 & 7.7 & 45.6 & 11.4 & 524 & 26 & 2.6 & 17 & 19 & 588 & 88 & 1047 & 94.6 & 535 \\
\hline $\begin{array}{l}2 \mathrm{H}-4,145-150 \\
3 \mathrm{H}-1,145-150\end{array}$ & $\begin{array}{l}13.25 \\
18.25\end{array}$ & $\begin{array}{l}\text { W-sq } \\
\text { IW-sq }\end{array}$ & $\begin{array}{l}40 \\
36\end{array}$ & $\begin{array}{l}19.0 \\
21.5\end{array}$ & $\begin{array}{l}7.6 \\
7.7\end{array}$ & $\begin{array}{l}34 \\
34\end{array}$ & $\begin{array}{l}538 \\
535\end{array}$ & 559 & 12.3 & 0.87 & $\begin{array}{l}436 \\
445\end{array}$ & $\begin{array}{l}6.5 \\
5.6\end{array}$ & $\begin{array}{l}42.5 \\
41.3\end{array}$ & $\begin{array}{l}10.8 \\
10.8\end{array}$ & $\begin{array}{l}586 \\
623\end{array}$ & $\begin{array}{r}12 \\
9\end{array}$ & $\begin{array}{l}B D \\
B D\end{array}$ & $\begin{array}{l}15 \\
18\end{array}$ & $\begin{array}{r}16 \\
9\end{array}$ & $\begin{array}{l}589 \\
625\end{array}$ & $\begin{array}{l}83 \\
88\end{array}$ & $\begin{array}{l}1080 \\
1521\end{array}$ & $\begin{array}{r}98.7 \\
1023\end{array}$ & $\begin{array}{l}612 \\
599\end{array}$ \\
\hline $\begin{array}{l}3 \mathrm{H}-\mathrm{I}, 45-130 \\
3 \mathrm{H}-4,145-150\end{array}$ & $\begin{array}{l}18.23 \\
22.75\end{array}$ & $\begin{array}{l}\text { W } \\
\text { IW-sq }\end{array}$ & $\begin{array}{l}36 \\
40\end{array}$ & $\begin{array}{l}21.3 .4 \\
24.4\end{array}$ & 7.6 & $\begin{array}{l}34 \\
34\end{array}$ & 536 & 557 & 6.0 & 0.88 & $\begin{array}{l}443 \\
437\end{array}$ & $\begin{array}{l}5.6 \\
5.3\end{array}$ & $\begin{array}{l}41.3 \\
40.4\end{array}$ & $\begin{array}{l}0.8 \\
10.7\end{array}$ & $\begin{array}{l}623 \\
552\end{array}$ & 22 & $\begin{array}{l}\mathrm{BD} \\
1.1\end{array}$ & $\begin{array}{l}18 \\
19\end{array}$ & 10 & $\begin{array}{l}623 \\
628\end{array}$ & $\begin{array}{l}88 \\
88\end{array}$ & $\begin{array}{l}151 \\
1761\end{array}$ & $\begin{array}{l}102.3 \\
1056\end{array}$ & $\begin{array}{l}599 \\
620\end{array}$ \\
\hline $4 \mathrm{H}-1,140-145$ & 27.70 & IW-sq & 40 & 24.9 & 7.4 & $\begin{array}{l}34 \\
34\end{array}$ & 532 & 553 & 4.1 & $\begin{array}{l}0.00 \\
0.87\end{array}$ & 432 & 4.8 & $\begin{array}{l}4.4 \\
38.8\end{array}$ & 10.2 & 615 & 24 & 9.1 & 23 & 3 & $\begin{array}{l}620 \\
641\end{array}$ & $\begin{array}{l}100 \\
92\end{array}$ & 1946 & 105.3 & $\begin{array}{l}200 \\
665\end{array}$ \\
\hline $4 \mathrm{H}-4,145-150$ & 32.20 & IW-sq & 36 & 25.6 & 7.4 & 34 & 534 & 553 & 2.6 & 0.88 & 452 & 4.6 & 39.3 & 10.7 & 621 & 55 & 4.3 & 29 & 1 & 751 & 103 & 1852 & 101.8 & 720 \\
\hline $5 \mathrm{H}-1,145-150$ & 37.25 & IW-Sq & 38 & 26.1 & 7.4 & 34 & 529 & 562 & 1.8 & 0.90 & 450 & 4.7 & 38.4 & 10.4 & 608 & 62 & 2.0 & 30 & BD & 750 & 107 & 2058 & 97.8 & 755 \\
\hline $5 \mathrm{H}-4,145-150$ & 41.75 & IW-Sq & 42 & 27.1 & 7.4 & 34 & 535 & 560 & 1.0 & 0.90 & 438 & 4.7 & 37.0 & 10.2 & 651 & 229 & 6.7 & 36 & BD & 776 & 119 & 2201 & 93.5 & 747 \\
\hline $\begin{array}{l}6 \mathrm{H}-1,145-150 \\
6 \mathrm{H}-4\end{array}$ & $\begin{array}{l}46.75 \\
5120\end{array}$ & $\begin{array}{l}\text { IW-Sq } \\
\text { WW-Sg }\end{array}$ & $\begin{array}{l}40 \\
42\end{array}$ & 27.1 & 7.4 & 34 & 539 & & & & 435 & $\begin{array}{l}4.9 \\
50\end{array}$ & $\begin{array}{l}35.8 \\
25.4\end{array}$ & 10.1 & $\begin{array}{l}616 \\
620\end{array}$ & 692 & $\begin{array}{l}4.7 \\
68\end{array}$ & 35 & BD & $\begin{array}{l}736 \\
822\end{array}$ & 120 & $\begin{array}{r}2339 \\
2246\end{array}$ & 93.7 & 749 \\
\hline $\begin{array}{l}6-4-4,145-150 \\
7-1,145-150\end{array}$ & $\begin{array}{l}51.20 \\
56.25\end{array}$ & $\begin{array}{l}\text { WW-sq } \\
\text { IW-sq }\end{array}$ & $\begin{array}{l}42 \\
40\end{array}$ & 27.7 & 7.4 & $\begin{array}{l}34 \\
33\end{array}$ & 542 & 562 & 0.6 & 0.90 & $\begin{array}{l}436 \\
457\end{array}$ & $\begin{array}{l}5.0 \\
5.6\end{array}$ & $\begin{array}{l}35.4 \\
36.5\end{array}$ & $\begin{array}{l}10.0 \\
10.4\end{array}$ & $\begin{array}{l}629 \\
629\end{array}$ & $\begin{array}{l}1373 \\
2455\end{array}$ & $\begin{array}{l}6.8 \\
3.7\end{array}$ & $\begin{array}{l}33 \\
32\end{array}$ & $\begin{array}{c}1 \\
B D\end{array}$ & $\begin{array}{l}832 \\
791\end{array}$ & $\begin{array}{l}128 \\
137\end{array}$ & $\begin{array}{l}2336 \\
2352\end{array}$ & $\begin{array}{l}76.7 \\
69.9\end{array}$ & $\begin{array}{l}804 \\
813\end{array}$ \\
\hline $7 \mathrm{H}-4,145-150$ & & IW-sq & 37 & 27.7 & 7.3 & 34 & 539 & & & & 436 & $\begin{array}{l}5.0 \\
5.5\end{array}$ & S0.5 & $\begin{array}{l}10.4 \\
9.8\end{array}$ & $\begin{array}{l}029 \\
680\end{array}$ & 3375 & 5.1 & 32 & $\begin{array}{l}\mathrm{DU} \\
\mathrm{BD}\end{array}$ & 878 & 131 & 2185 & $\begin{array}{l}09.9 \\
63.9\end{array}$ & $\begin{array}{l}813 \\
845\end{array}$ \\
\hline $8 \mathrm{H}-1,145-150$ & 65.75 & IW-sq & 50 & & & 34 & & 563 & 0.7 & 0.90 & 453 & 6.1 & $\begin{array}{l}34.9 \\
34.9\end{array}$ & $\begin{array}{l}9.0 \\
10.1\end{array}$ & 679 & 3453 & 2.9 & 31 & 1 & 848 & 147 & 2434 & $\begin{array}{l}0.9 \\
60.1\end{array}$ & 847 \\
\hline $8 \mathrm{H}-4,145-150$ & 70.25 & IW-sq & 44 & 27.3 & 7.4 & 34 & 540 & & & & 470 & 6.4 & 35.4 & 10.5 & 763 & 4317 & 5.0 & 38 & 2 & 1024 & 172 & 2141 & 50.5 & 906 \\
\hline $9 \mathrm{H}-1,145-150$ & 75.25 & IW-Sq & 40 & 26.4 & 7.4 & 34 & 541 & 563 & 0.4 & 0.91 & 467 & 6.6 & 34.5 & 10.3 & 758 & 4325 & BD & 38 & 3 & 912 & 162 & 2317 & 43.3 & 904 \\
\hline $\begin{array}{l}9 \mathrm{H}-4,145-150 \\
10 \mathrm{H}-145-15\end{array}$ & $\begin{array}{l}79.75 \\
8475\end{array}$ & IW-Sq & 50 & 26.3 & 7.5 & 34 & $\begin{array}{l}543 \\
544\end{array}$ & & & & 471 & 7.0 & 34.5 & 10.2 & 653 & 4454 & 1.1 & 40 & 4 & 894 & 162 & 2337 & 38.6 & $\begin{array}{l}899 \\
020\end{array}$ \\
\hline $\begin{array}{l}10 \mathrm{H}-1,145-150 \\
10-4,445-150\end{array}$ & $\begin{array}{l}84.75 \\
89.25\end{array}$ & $\begin{array}{l}\text { W-sq } \\
\text { IW-sa }\end{array}$ & $\begin{array}{l}40 \\
44\end{array}$ & $\begin{array}{l}26.2 \\
25.8\end{array}$ & $\begin{array}{l}7.4 \\
7.4\end{array}$ & $\begin{array}{l}34 \\
33\end{array}$ & $\begin{array}{l}541 \\
543\end{array}$ & & & & $\begin{array}{l}464 \\
468\end{array}$ & $\begin{array}{l}7.2 \\
7.4\end{array}$ & $\begin{array}{l}33.8 \\
33.4\end{array}$ & $\begin{array}{l}10.0 \\
10.1\end{array}$ & $\begin{array}{l}711 \\
743\end{array}$ & $\begin{array}{l}4606 \\
4763\end{array}$ & $\begin{array}{l}4.6 \\
3.8\end{array}$ & $\begin{array}{l}45 \\
46\end{array}$ & 9 & $\begin{array}{l}933 \\
934\end{array}$ & $\begin{array}{l}167 \\
167\end{array}$ & $\begin{array}{l}2106 \\
233\end{array}$ & $\begin{array}{l}38.1 \\
380\end{array}$ & $\begin{array}{l}938 \\
999\end{array}$ \\
\hline $\begin{array}{l}10 \mathrm{H}-4,145-150 \\
11 \mathrm{H}-1,145-150\end{array}$ & $\begin{array}{l}89.25 \\
94.25\end{array}$ & $\begin{array}{l}\text { W-sq } \\
\text { IW-sq }\end{array}$ & $\begin{array}{l}44 \\
46\end{array}$ & $\begin{array}{l}25.8 \\
24.8\end{array}$ & $\begin{array}{l}7.4 \\
7.5\end{array}$ & $\begin{array}{l}33 \\
34\end{array}$ & $\begin{array}{l}543 \\
544\end{array}$ & $\begin{array}{l}567 \\
559\end{array}$ & $\begin{array}{l}0.4 \\
0.5\end{array}$ & $\begin{array}{l}0.92 \\
0.90\end{array}$ & $\begin{array}{l}468 \\
467\end{array}$ & $\begin{array}{l}7.4 \\
7.7\end{array}$ & $\begin{array}{l}33.4 \\
32.7\end{array}$ & $\begin{array}{l}10.1 \\
10.0\end{array}$ & $\begin{array}{l}743 \\
718\end{array}$ & $\begin{array}{l}4763 \\
4775\end{array}$ & $\begin{array}{l}3.8 \\
B D\end{array}$ & $\begin{array}{l}46 \\
52\end{array}$ & $\stackrel{9}{9}$ & $\begin{array}{l}934 \\
927\end{array}$ & $\begin{array}{l}167 \\
172\end{array}$ & $\begin{array}{l}2233 \\
2144\end{array}$ & $\begin{array}{l}38.0 \\
34.2\end{array}$ & $\begin{array}{l}999 \\
933\end{array}$ \\
\hline $11 \mathrm{H}-4,145-150$ & 98.75 & IW-sq & 38 & 24.6 & 7.4 & 34 & 542 & 561 & 0.5 & 0.91 & 462 & 7.8 & 32.4 & 9.9 & 769 & 4967 & $\mathrm{BD}$ & 55 & 11 & 1006 & 177 & 2307 & 32.5 & 992 \\
\hline $12 \mathrm{H}-1,145-150$ & 103.75 & IW-Sq & $\begin{array}{l}48 \\
55\end{array}$ & $\begin{aligned} 23.9 \\
230\end{aligned}$ & 7.3 & 33 & 544 & & & & 468 & $\begin{array}{l}8.0 \\
81\end{array}$ & 32.3 & 9.6 & $\begin{array}{l}830 \\
821\end{array}$ & 5289 & $\begin{array}{l}2.0 \\
3.0\end{array}$ & 59 & 12 & 1039 & 184 & 2298 & 35.9 & 998 \\
\hline $12 \mathrm{H}-4,145-150$ & 108.25 & IW-Sq & 52 & 23.9 & 7.7 & 33 & 543 & & & & 466 & 8.1 & 31.6 & 9.7 & 831 & 5056 & 3.9 & 61 & 12 & 1111 & 177 & 2387 & 26.7 & 1095 \\
\hline $\begin{array}{l}13 \mathrm{H}-1,145-150 \\
13 \mathrm{H}-4,45-150\end{array}$ & & IW-Sq & $\begin{array}{l}48 \\
56\end{array}$ & 223 & 7.4 & 33 & $\begin{array}{l}543 \\
537\end{array}$ & 564 & 0.5 & 0.92 & $\begin{array}{l}466 \\
470\end{array}$ & $\begin{array}{l}8.3 \\
8.4\end{array}$ & $\begin{array}{l}31.1 \\
30.9\end{array}$ & $\begin{array}{l}9.6 \\
9.6\end{array}$ & $\begin{array}{l}831 \\
827\end{array}$ & 4863 & & & $\begin{array}{l}12 \\
11\end{array}$ & $\begin{array}{l}1064 \\
1116\end{array}$ & $\begin{array}{l}184 \\
180\end{array}$ & & & $\begin{array}{l}1040 \\
1065\end{array}$ \\
\hline $\begin{array}{l}13 \mathrm{H}-4,1,45-150 \\
14 \mathrm{H}-1,145-150\end{array}$ & $\begin{array}{l}1177.75 \\
122.75\end{array}$ & $\begin{array}{l}\text { W-sq } \\
\text { IW-sa }\end{array}$ & $\begin{array}{l}56 \\
44\end{array}$ & $\begin{array}{l}22.3 \\
22.1\end{array}$ & $\begin{array}{l}7.4 \\
7.3\end{array}$ & $\begin{array}{l}33 \\
33\end{array}$ & $\begin{array}{l}537 \\
544\end{array}$ & 564 & 0.5 & 0.91 & $\begin{array}{l}470 \\
472\end{array}$ & $\begin{array}{l}8.4 \\
8.6\end{array}$ & $\begin{array}{l}30.9 \\
30.6\end{array}$ & $\begin{array}{l}9.6 \\
9.5\end{array}$ & $\begin{array}{l}827 \\
871\end{array}$ & $\begin{array}{l}4863 \\
4737\end{array}$ & $\begin{array}{l}4.3 \\
2.1\end{array}$ & $\begin{array}{l}67 \\
72\end{array}$ & $\begin{array}{l}11 \\
11\end{array}$ & $\begin{array}{l}1116 \\
1136\end{array}$ & $\begin{array}{l}180 \\
183\end{array}$ & $\begin{array}{l}2369 \\
2004\end{array}$ & $\begin{array}{l}21.2 \\
21.8\end{array}$ & $\begin{array}{l}1065 \\
1098\end{array}$ \\
\hline $\begin{array}{l}14 \mathrm{H}-\mathrm{I}, \mathrm{N}, 45-150 \\
14-4,145-150\end{array}$ & 127.25 & IW-sq & 52 & 21.8 & 7.3 & 33 & $\begin{array}{l}544 \\
545\end{array}$ & 364 & 0.5 & 0.91 & 467 & $\begin{array}{l}0.0 \\
8.6\end{array}$ & 30.0 & $\begin{array}{l}9.3 \\
9.5\end{array}$ & 866 & $\begin{array}{l}4539 \\
4539\end{array}$ & $\begin{array}{l}2.1 \\
5.0\end{array}$ & 76 & 10 & 11145 & $\begin{array}{l}183 \\
184\end{array}$ & $\begin{array}{l}2004 \\
2199\end{array}$ & $\begin{array}{l}21.8 \\
13.4\end{array}$ & $\begin{array}{l}1098 \\
1115\end{array}$ \\
\hline $15 \mathrm{H}-1,145-150$ & & in & 51 & 20.8 & 7.3 & 33 & 542 & & & & & & & & & & & & & & & 21 & 12.8 & 1103 \\
\hline $15 \mathrm{H}-4$, & $\begin{array}{l}136.75 \\
13.75\end{array}$ & in & 43 & 21.0 & $\begin{array}{l}7.5 \\
.5\end{array}$ & 33 & $\begin{array}{l}542 \\
5\end{array}$ & & & & 468 & 8.8 & 29.5 & 9.4 & 827 & 40 & 5.7 & 81 & 7 & 11 & 182 & & 16.1 & \\
\hline 16 & $\begin{array}{l}141.75 \\
146.25\end{array}$ & $\begin{array}{l}\text { IW-Sq } \\
\text { WW-sq }\end{array}$ & $\begin{array}{l}42 \\
48\end{array}$ & 19. & 7.3 & 33 & $\begin{array}{l}551 \\
543\end{array}$ & & & & 47 & 9.0 & 29 & 9.1 & 957 & & 2.0 & 92 & 7 & 1 & & 1994 & 6.6 & 40 \\
\hline & 25 & IM & $\begin{array}{l}48 \\
44\end{array}$ & $\begin{array}{l}20 \\
19\end{array}$ & 7.2 & 33 & $\begin{array}{l}543 \\
543\end{array}$ & 559 & $\begin{array}{l}0.4 \\
0.5\end{array}$ & $\begin{array}{l}0.91 \\
0.91\end{array}$ & $\begin{array}{l}47 \\
47\end{array}$ & $\begin{array}{l}9.0 \\
9.5\end{array}$ & 29 & $\begin{array}{l}9.2 \\
89\end{array}$ & 07 & & 4.2 & 87 & 7 & & 18 & & 71 & 82 \\
\hline $\begin{array}{l}17-1,1 \\
17 H-4,1\end{array}$ & & & 47 & 19.8 & 7.3 & 33 & 545 & 563 & 0.4 & 0.92 & 461 & 9.6 & 28 & $\begin{array}{l}8.9 \\
8.9\end{array}$ & & & 3.7 & $\begin{array}{l}92 \\
92\end{array}$ & $\begin{array}{l}14 \\
15\end{array}$ & & & & 7.4 & 82 \\
\hline $\begin{array}{l}17-4-4,145-150 \\
18 H-1,145-150\end{array}$ & 160.55 & IW-sq & 52 & 19.4 & 7.3 & 33 & 541 & & & & 468 & 10.1 & 27.8 & $\begin{array}{l}8.9 \\
8.8\end{array}$ & $\begin{array}{l}910 \\
909\end{array}$ & & $\begin{array}{l}1.0 \\
1.1\end{array}$ & 95 & 18 & & & & 1.0 & $\begin{array}{l}1204 \\
1164\end{array}$ \\
\hline 18 & 10 & IW & $\pi$ & 19.1 & 7.5 & 33 & 544 & & & & 464 & 10 & 27.2 & 8.7 & & & & o & 10 & & & & 0.2 & tr \\
\hline $19 \mathrm{r}$ & 170.05 & $\mathrm{IW}$ & 48 & 19.0 & 7.3 & 33 & 540 & & & & . & 10.2 & 26 & 8.4 & 947 & & 1.6 & 98 & 23 & & & & 5.0 & 08 \\
\hline 19 & 174 & $\|$ & 56 & 19.0 & 7.3 & 32 & 547 & 560 & 0.4 & 0.91 & 462 & 10.5 & 26 & 8.6 & 1009 & & 0 & 104 & 25 & & & & 9.0 & 1254 \\
\hline $20 \mathrm{r}$ & 175 & $\|$ & $\begin{array}{l}45 \\
54\end{array}$ & 18.5 & 7.3 & 3 & 541 & & & & 468 & 11 & 26 & 8.5 & 970 & 3 & 1.3 & 102 & 24 & 1 & 19 & 1 & 4.0 & 1260 \\
\hline & & & $\begin{array}{l}4_{44}^{4} \\
\text {. }\end{array}$ & $\begin{array}{l}18.6 \\
18.5\end{array}$ & 72 & 3 & $\begin{array}{l}537 \\
540\end{array}$ & 555 & 0.4 & 0.90 & $\begin{array}{l}45 \\
47\end{array}$ & 10 & & $\begin{array}{l}8.4 \\
85\end{array}$ & 10 & & 2.2 & 101 & 25 & & 19 & & 6.2 & 34 \\
\hline & & in & 48 & $\begin{array}{l}18.3 \\
18.2\end{array}$ & 7.2 & 33 & $\begin{array}{l}530 \\
538\end{array}$ & 562 & 0.4 & 0.92 & 469 & & & $\begin{array}{l}8.5 \\
8.3\end{array}$ & $\begin{array}{l}11 \\
16\end{array}$ & & .0 & & $\begin{array}{l}30 \\
27\end{array}$ & & & & $\begin{array}{l}6.8 \\
7.2\end{array}$ & \\
\hline & & & 45 & 17 & 9.2 & & 540 & J02 & 0.4 & 0.92 & $\begin{array}{l}46 \\
45\end{array}$ & & & & 10 & & & & 25 & & & & 7.7 & 68 \\
\hline $22 \mathrm{H}-4,145-150$ & 203.05 & IW-Sq & 44 & 17.9 & 7.3 & 32 & 534 & & & & 465 & 11.6 & 25.1 & 8.1 & 1089 & 3236 & $\mathrm{BD}$ & 109 & 27 & 1382 & 203 & 1910 & 5.0 & 87 \\
\hline & & & & & & & & & & & & & & & & & & & & & & & & \\
\hline & 196 & IV & 36 & 18.0 & 7.2 & 33 & 541 & 550 & 0.5 & 0.90 & 466 & 11 & 25 & 8.0 & 1042 & 3079 & 1.8 & 103 & 25 & 1 & 192 & 1916 & & 1354 \\
\hline & & & $\begin{array}{l}40 \\
44\end{array}$ & 17.9 & 7.3 & 32 & $\begin{array}{l}544 \\
539\end{array}$ & & & & 46 & 1 & 25 & 8.2 & 16 & & BD & & 24 & & 100 & & & 1344 \\
\hline 26 & 225.05 & IW & 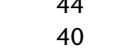 & 16.3 & 7.1 & $\begin{array}{l}32 \\
32\end{array}$ & $\begin{array}{l}339 \\
540\end{array}$ & 560 & 0.6 & 0.91 & 457 & 12 & 24 & $\begin{array}{l}7.8 \\
7.8\end{array}$ & 11 & & 1.2 & 113 & 29 & & 206 & 30 & & 12 \\
\hline & & & 52 & & 7.2 & & 5 & & & & & & & 7.5 & & & BD & & 27 & & 198 & & & 52 \\
\hline $28 \mathrm{H}-3,145-150$ & 244.05 & IW-sq & 44 & 15.4 & 7.3 & 33 & 539 & & & & 463 & 13.2 & 23.3 & 7.4 & 1072 & 2860 & $\mathrm{BD}$ & 110 & 25 & 1403 & 202 & 1776 & & 1415 \\
\hline
\end{tabular}

$M L=$ mudline, IW-Sq = interstitial water from whole-round squeezing. ISE = inn-selective electrode, Refract = refractometer, IC = ion chromatograph, ICP = inductively coupled plasma-atomic emission spectroscopy, Spec = UV-VIS spectrophotometer. BD = below detection. 
Table T12. Headspace (HS) gas concentrations, Site U1423.

\begin{tabular}{|c|c|c|c|c|c|}
\hline $\begin{array}{l}\text { Core, section, } \\
\text { interval }(\mathrm{cm})\end{array}$ & $\begin{array}{l}\text { Top depth } \\
\text { CSF-A (m) }\end{array}$ & $\begin{array}{l}\text { Sample } \\
\text { type }\end{array}$ & $\begin{array}{l}\text { Sediment } \\
\text { volume } \\
\left(\mathrm{cm}^{3}\right)\end{array}$ & $\begin{array}{c}\mathrm{CH}_{4} \\
\text { mppmv) } \\
\text { measured }\end{array}$ & $\begin{array}{c}\mathrm{CH}_{4} \\
(\mathrm{ppmv}) \\
\text { normalized }\end{array}$ \\
\hline \multicolumn{6}{|l|}{ 346-U1423A- } \\
\hline $1 \mathrm{H}-2,0-5$ & 1.50 & $\mathrm{HS}$ & 4.00 & 7.95 & 9.94 \\
\hline $1 \mathrm{H}-5,0-5$ & 6.00 & HS & 4.00 & 1.88 & 2.35 \\
\hline $2 \mathrm{H}-2,0-5$ & 8.80 & HS & 2.00 & 1.73 & 4.33 \\
\hline $2 \mathrm{H}-5,0-5$ & 13.30 & HS & 4.00 & 0.00 & 0.00 \\
\hline $3 \mathrm{H}-2,0-5$ & 18.30 & $\mathrm{HS}$ & 4.00 & 3.42 & 4.28 \\
\hline $3 \mathrm{H}-5,0-5$ & 22.80 & HS & 4.00 & 5.26 & 6.58 \\
\hline $4 \mathrm{H}-2,0-5$ & 27.75 & $\mathrm{HS}$ & 3.60 & 24.41 & 33.90 \\
\hline $4 \mathrm{H}-5,0-5$ & 32.25 & HS & 4.00 & 97.56 & 121.95 \\
\hline $5 \mathrm{H}-2,0-5$ & 37.30 & HS & 4.00 & 155.76 & 194.70 \\
\hline $5 \mathrm{H}-5,0-5$ & 41.80 & HS & 4.00 & 232.16 & 290.20 \\
\hline $6 \mathrm{H}-2,0-5$ & 46.80 & HS & 4.00 & 350.17 & 437.71 \\
\hline $6 \mathrm{H}-5,0-5$ & 51.25 & HS & 4.00 & 343.62 & 429.53 \\
\hline $7 \mathrm{H}-2,0-5$ & 56.30 & HS & 3.20 & 665.77 & 1040.27 \\
\hline $7 \mathrm{H}-5,0-5$ & 60.80 & HS & 4.80 & 1076.44 & 1121.29 \\
\hline $8 \mathrm{H}-2,0-5$ & 65.80 & $\mathrm{HS}$ & 4.00 & 1377.24 & 1721.55 \\
\hline $8 \mathrm{H}-5,0-5$ & 70.30 & $\mathrm{HS}$ & 3.00 & 1203.62 & 2006.03 \\
\hline $9 \mathrm{H}-2,0-5$ & 75.30 & HS & 3.00 & 903.74 & 1506.23 \\
\hline $9 \mathrm{H}-5,0-5$ & 79.80 & HS & 3.00 & 876.44 & 1460.73 \\
\hline $10 \mathrm{H}-2,0-5$ & 84.80 & HS & 3.00 & 621.05 & 1035.08 \\
\hline $10 \mathrm{H}-5,0-5$ & 89.30 & HS & 3.20 & 403.45 & 630.39 \\
\hline $11 \mathrm{H}-2,0-5$ & 94.30 & HS & 3.00 & 253.79 & 422.98 \\
\hline $11 \mathrm{H}-5,0-5$ & 98.80 & HS & 3.00 & 228.66 & 381.10 \\
\hline $12 \mathrm{H}-2,0-5$ & 103.80 & HS & 3.00 & 308.96 & 514.93 \\
\hline $12 \mathrm{H}-5,0-5$ & 108.30 & HS & 3.00 & 180.52 & 300.87 \\
\hline $13 \mathrm{H}-2,0-5$ & 113.30 & $\mathrm{HS}$ & 3.00 & 105.75 & 176.25 \\
\hline $13 \mathrm{H}-5,0-5$ & 117.80 & HS & 3.20 & 122.16 & 190.88 \\
\hline $14 \mathrm{H}-2,0-5$ & 122.80 & $\mathrm{HS}$ & 2.60 & 30.20 & 58.08 \\
\hline $14 \mathrm{H}-5,0-5$ & 127.30 & HS & 3.20 & 37.48 & 58.56 \\
\hline $15 \mathrm{H}-2,0-5$ & 132.30 & HS & 3.20 & 13.72 & 21.44 \\
\hline $15 \mathrm{H}-5,0-5$ & 136.80 & HS & 3.40 & 10.23 & 15.04 \\
\hline $16 \mathrm{H}-2,0-5$ & 141.80 & HS & 2.80 & 6.78 & 12.11 \\
\hline $16 \mathrm{H}-5,0-5$ & 146.30 & HS & 3.20 & 8.25 & 12.89 \\
\hline $17 \mathrm{H}-2,0-5$ & 151.30 & HS & 3.00 & 6.49 & 10.82 \\
\hline $17 \mathrm{H}-5,0-5$ & 155.80 & HS & 3.60 & 6.63 & 9.21 \\
\hline $18 \mathrm{H}-2,0-5$ & 160.60 & HS & 3.00 & 3.93 & 6.55 \\
\hline $18 \mathrm{H}-5,0-5$ & 165.10 & HS & 2.60 & 3.42 & 6.58 \\
\hline $19 \mathrm{H}-2,0-5$ & 170.10 & $\mathrm{HS}$ & 3.00 & 3.45 & 5.75 \\
\hline $19 \mathrm{H}-5,0-5$ & 174.60 & $\mathrm{HS}$ & 3.40 & 3.82 & 5.62 \\
\hline $20 \mathrm{H}-2,0-5$ & 179.60 & $\mathrm{HS}$ & 3.20 & 2.87 & 4.48 \\
\hline $20 \mathrm{H}-5,0-5$ & 184.10 & $\mathrm{HS}$ & 3.40 & 2.66 & 3.91 \\
\hline $21 \mathrm{H}-2,0-5$ & 189.10 & $\mathrm{HS}$ & 3.80 & 3.39 & 4.46 \\
\hline $21 \mathrm{H}-5,0-5$ & 193.60 & HS & 3.40 & 3.03 & 4.46 \\
\hline $22 \mathrm{H}-2,0-5$ & 198.60 & HS & 2.80 & 2.78 & 4.96 \\
\hline $22 \mathrm{H}-5,0-5$ & 203.10 & $\mathrm{HS}$ & 2.80 & 2.95 & 5.27 \\
\hline \multicolumn{6}{|l|}{ 346-U1423B- } \\
\hline $23 \mathrm{H}-4,0-5$ & 196.60 & HS & 3.00 & 2.69 & 4.48 \\
\hline $24 \mathrm{H}-4,0-5$ & 206.10 & HS & 3.20 & 2.29 & 3.58 \\
\hline $25 \mathrm{H}-4,0-5$ & 215.60 & HS & 3.40 & 3.46 & 5.09 \\
\hline $26 \mathrm{H}-4,0-5$ & 225.10 & HS & 3.20 & 2.63 & 4.11 \\
\hline $27 \mathrm{H}-4,0-5$ & 234.60 & HS & 3.00 & 2.77 & 4.62 \\
\hline $28 \mathrm{H}-4,0-5$ & 244.10 & HS & 2.60 & 3.46 & 6.65 \\
\hline
\end{tabular}


Table T13. FlexIT tool core orientation data, Hole U1423A.

\begin{tabular}{crc}
\hline Core & $\begin{array}{c}\text { Orientation } \\
\text { angle } \\
\left({ }^{\circ}\right)\end{array}$ & $\begin{array}{c}\text { Orientation } \\
\text { standard } \\
\left({ }^{\circ}\right)\end{array}$ \\
\hline $346-\mathrm{U} 1423 \mathrm{~A}-$ & & \\
$2 \mathrm{H}$ & 91.03 & 1.45 \\
$3 \mathrm{H}$ & 234.20 & 0.57 \\
$4 \mathrm{H}$ & 295.28 & 0.62 \\
$5 \mathrm{H}$ & 213.33 & 0.64 \\
$6 \mathrm{H}$ & 152.64 & 0.39 \\
$7 \mathrm{H}$ & 157.09 & 0.59 \\
$8 \mathrm{H}$ & 28.57 & 0.28 \\
$9 \mathrm{H}$ & 113.44 & 0.18 \\
$10 \mathrm{H}$ & 16.54 & 0.35 \\
$11 \mathrm{H}$ & 151.09 & 0.61 \\
$12 \mathrm{H}$ & 32.27 & 4.44 \\
$14 \mathrm{H}$ & 265.66 & 0.18 \\
$15 \mathrm{H}$ & 215.65 & 0.22 \\
$16 \mathrm{H}$ & 0.57 & 0.25 \\
$17 \mathrm{H}$ & 114.14 & 0.11 \\
$18 \mathrm{H}$ & 54.03 & 0.33 \\
$19 \mathrm{H}$ & 143.18 & 0.24 \\
$20 \mathrm{H}$ & 31.85 & 0.37 \\
$21 \mathrm{H}$ & 332.78 & 0.23 \\
$22 \mathrm{H}$ & 19.60 & 0.27 \\
\hline
\end{tabular}


Table T14. Core disturbance intervals, Site U1423. (Continued on next page.)

\begin{tabular}{|c|c|c|}
\hline Core, section & Comments on disturbance & $\begin{array}{l}\text { Drilling disturbance } \\
\text { intensity }\end{array}$ \\
\hline \multicolumn{3}{|l|}{ 346-U1423A- } \\
\hline $1 \mathrm{H}-2,26-30$ & Soupy & High \\
\hline $1 \mathrm{H}-2,125-125$ & Washed out ash layer? & \\
\hline $1 \mathrm{H}-3,14-109$ & Disturbance and ash & \\
\hline $1 \mathrm{H}-4,71-88$ & Ash mixed layer & \\
\hline $1 \mathrm{H}-4,110-113$ & Flow-in & \\
\hline $1 \mathrm{H}-\mathrm{CC}, 0-16$ & & High \\
\hline $2 \mathrm{H}-1,0-8$ & Slurry & Moderate \\
\hline $2 \mathrm{H}-\mathrm{CC}, 0-16$ & & Moderate to high \\
\hline $3 \mathrm{H}-1,38-40$ & Disturbance & \\
\hline $3 \mathrm{H}-1,66-71$ & Void & Destroyed \\
\hline $3 \mathrm{H}-1,102-150$ & Crack & Moderate to high \\
\hline $3 \mathrm{H}-1,120-122$ & Void & Destroyed \\
\hline $3 \mathrm{H}-5,0-12$ & Disturbance & \\
\hline $3 \mathrm{H}-\mathrm{CC}, 0-18$ & & Moderate \\
\hline $4 \mathrm{H}-5,118-150$ & Flow-in & High \\
\hline $4 \mathrm{H}-6,122-127$ & Disturbance & \\
\hline $5 \mathrm{H}-1,0-3$ & Disturbance & \\
\hline $5 \mathrm{H}-7,52-56$ & Disturbance & \\
\hline $5 \mathrm{H}-\mathrm{CC}, 0-25$ & & Moderate \\
\hline $6 \mathrm{H}-1,0-36$ & Thick soupy ash and disturbance & \\
\hline \multicolumn{3}{|l|}{$6 \mathrm{H}-2,140-145$} \\
\hline $6 \mathrm{H}-\mathrm{CC}, 0-22$ & & Moderate \\
\hline $7 \mathrm{H}-1,0-10$ & Disturbance & \\
\hline $7 \mathrm{H}-1,15-15$ & Ash mixed layer & \\
\hline $7 \mathrm{H}-2,80-80$ & Ice-rafted debris & \\
\hline $7 \mathrm{H}-5,15-30$ & Microfault & \\
\hline 7H-5, 85-93 & Microfault & \\
\hline 7H-CC, $0-29$ & & Slight \\
\hline $8 \mathrm{H}-2,125-135$ & Tilted & \\
\hline $8 \mathrm{H}-4,92-139$ & Tilted & \\
\hline $8 \mathrm{H}-5,110-150$ & Tilted & \\
\hline $8 \mathrm{H}-7,16-32$ & Bowed & Moderate \\
\hline $8 \mathrm{H}-\mathrm{CC}, 0-32$ & & Slight \\
\hline $9 \mathrm{H}-1,0-10$ & Disturbance & \\
\hline $9 \mathrm{H}-6,89-150$ & Microfault & \\
\hline $9 \mathrm{H}-\mathrm{CC}, 0-8$ & & Slight \\
\hline $12 \mathrm{H}-4,31-44$ & Deformed? & \\
\hline $12 \mathrm{H}-5,6-8$ & Microfault & \\
\hline $13 \mathrm{H}-1,0-42$ & Disturbance & \\
\hline $13 \mathrm{H}-2,109-122$ & Tilted & \\
\hline $13 \mathrm{H}-2,131-135$ & Tilted & \\
\hline $13 \mathrm{H}-3,0-15$ & Disturbance & \\
\hline $13 \mathrm{H}-4,36-41$ & Disturbance & \\
\hline $13 \mathrm{H}-7,0-10$ & Disturbance & \\
\hline $14 \mathrm{H}-, 0-61$ & Suck in & Severe \\
\hline $14 \mathrm{H}-, 240-994$ & Suck in & Destroyed \\
\hline $15 \mathrm{H}-3,23-70$ & Suck in & Severe \\
\hline $16 \mathrm{H}-1,0-61$ & Suck in & Severe \\
\hline $16 \mathrm{H}-, 240-994$ & Suck in & Destroyed \\
\hline $17 \mathrm{H}-1,0-70$ & Flow-in? & \\
\hline $17 \mathrm{H}-4,0$-all to bottom & Flow-in? & \\
\hline $17 \mathrm{H}-\mathrm{CC}, 18-22$ & & Moderate to high \\
\hline $18 \mathrm{H}-1,0-15$ & Disturbance & \\
\hline $18 \mathrm{H}-2,0-36$ & Fall-in & Moderate to high \\
\hline $19 \mathrm{H}-1,0-20$ & Disturbance & \\
\hline $19 \mathrm{H}-\mathrm{CC}, 0-29$ & & Slight \\
\hline $20 \mathrm{H}-1,0-25$ & Disturbance & \\
\hline $20 \mathrm{H}-3,49-73$ & Flow-in & \\
\hline $20 \mathrm{H}-3,115-140$ & Microfault & \\
\hline $20 \mathrm{H}-6,83-95$ & Ash and deformed & \\
\hline $20 \mathrm{H}-\mathrm{CC}, 0-23$ & & Slight \\
\hline $21 \mathrm{H}-3,0-83$ & Flow-in? & \\
\hline $21 \mathrm{H}-\mathrm{CC}, 0-17$ & & Slight \\
\hline $22 \mathrm{H}-6,80-87$ & Tilted & \\
\hline $22 \mathrm{H}-\mathrm{CC}, 16-20$ & & Moderate \\
\hline
\end{tabular}


Table T14 (continued).

\begin{tabular}{|c|c|c|}
\hline Core, section & Comments on disturbance & $\begin{array}{l}\text { Drilling disturbance } \\
\text { intensity }\end{array}$ \\
\hline \multicolumn{3}{|l|}{ 346-U1423B- } \\
\hline $1 \mathrm{H}-1,0-3$ & Fall-in & Moderate \\
\hline $2 \mathrm{H}-1,67-70$ & Void & Destroyed \\
\hline $2 \mathrm{H}-\mathrm{CC}, 18-20$ & & Slight \\
\hline $4 \mathrm{H}-1,0-10$ & Soupy & Moderate to high \\
\hline $5 \mathrm{H}-1,0-5$ & & Slight \\
\hline $9 \mathrm{H}-1,0-3$ & & Destroyed \\
\hline $11 \mathrm{H}-1,128-150$ & & Slight \\
\hline $11 \mathrm{H}-7,9-19$ & & Slight \\
\hline $12 \mathrm{H}-\mathrm{CC}, 0-19$ & & Moderate \\
\hline $13 \mathrm{H}-\mathrm{CC}, 0-4$ & & Slight \\
\hline $14 \mathrm{H}-\mathrm{CC}, 5-20$ & & Moderate \\
\hline $15 \mathrm{H}-1,0-6$ & Fall-in & Moderate \\
\hline $15 \mathrm{H}-\mathrm{CC}, 0-4$ & & Slight \\
\hline $15 \mathrm{H}-\mathrm{CC}, 11-13$ & & Slight \\
\hline $16 \mathrm{H}-1,0-4$ & & Slight \\
\hline $17 \mathrm{H}-1,0-11$ & Fall-in & Moderate to high \\
\hline $17 \mathrm{H}-\mathrm{CC}, 0-23$ & & Slight \\
\hline $19 \mathrm{H}-1,0-2$ & & Slight \\
\hline $20 \mathrm{H}-\mathrm{CC}, 10-18$ & & Moderate \\
\hline $21 \mathrm{H}-\mathrm{CC}, 0-2$ & & Moderate \\
\hline $21 \mathrm{H}-\mathrm{CC}, 7-13$ & & Slight \\
\hline $22 \mathrm{H}-1,0-4$ & & Slight \\
\hline $22 \mathrm{H}-\mathrm{CC}, 0-25$ & & Slight \\
\hline $23 \mathrm{H}-1,0-5$ & & Slight \\
\hline $23 \mathrm{H}-\mathrm{CC}, 0-4$ & & Slight \\
\hline $24 \mathrm{H}-\mathrm{CC}, 0-4$ & & Slight \\
\hline $25 \mathrm{H}-1,0-12$ & & Slight to moderate \\
\hline $26 \mathrm{H}-7,30-40$ & & Slight \\
\hline $28 \mathrm{H}-4,38-74$ & & Slight to moderate \\
\hline $28 \mathrm{H}-6,99-150$ & & Slight to moderate \\
\hline \multicolumn{3}{|l|}{ 346-U1423C- } \\
\hline $2 \mathrm{H}-1,0-20$ & & Severe \\
\hline $2 \mathrm{H}-1,131-138$ & Microfault & \\
\hline $2 \mathrm{H}-6,0-8$ & Disturbance & \\
\hline $3 \mathrm{H}-3,47-61$ & Disturbance & \\
\hline $3 \mathrm{H}-5,0-12$ & Disturbance & \\
\hline $3 \mathrm{H}-\mathrm{CC}, 17.5-20$ & & Moderate \\
\hline $6 \mathrm{H}-1,1-3$ & & Moderate \\
\hline $6 \mathrm{H}-5,1-5$ & & Moderate \\
\hline $6 \mathrm{H}-\mathrm{CC}, 16-20$ & & High \\
\hline $8 \mathrm{H}-1,77-82$ & Tilted & \\
\hline $8 \mathrm{H}-1,122-130$ & Tilted & \\
\hline $8 \mathrm{H}-\mathrm{CC}, 0-6$ & & Moderate to high \\
\hline $8 \mathrm{H}-2,121-126$ & Ash disturbed layer & \\
\hline $9 \mathrm{H}-6,34-44$ & Tilted and mixed two different lithology & \\
\hline $9 \mathrm{H}-\mathrm{CC}, 11-25$ & & Moderate \\
\hline
\end{tabular}


Table T15. NRM inclination, declination, and intensity data after $20 \mathrm{mT}$ peak field AF demagnetization, Site U1423.

\begin{tabular}{|c|c|c|c|c|c|}
\hline $\begin{array}{l}\text { Core, section, } \\
\text { interval }(\mathrm{cm})\end{array}$ & $\begin{array}{c}\text { Depth } \\
\text { CSF-A (m) }\end{array}$ & $\begin{array}{l}\text { Inclination } \\
\left({ }^{\circ}\right)\end{array}$ & $\begin{array}{c}\text { Declination } \\
\left({ }^{\circ}\right)\end{array}$ & $\begin{array}{l}\text { FlexIT-corrected } \\
\text { declination } \\
\left({ }^{\circ}\right)\end{array}$ & $\begin{array}{c}\text { Intensity } \\
(\mathrm{A} / \mathrm{m})\end{array}$ \\
\hline \multicolumn{6}{|l|}{ 346-U1423A- } \\
\hline $1 \mathrm{H}-1,0$ & 0 & & & & \\
\hline $1 \mathrm{H}-1,5$ & 0.05 & & & & \\
\hline $1 \mathrm{H}-1,10$ & 0.10 & & & & \\
\hline $1 \mathrm{H}-1,15$ & 0.15 & 62.8 & 59 & & 0.024861 \\
\hline $1 \mathrm{H}-1,20$ & 0.20 & 64.5 & 60.7 & & 0.031384 \\
\hline $1 \mathrm{H}-1,25$ & 0.25 & 68.6 & 79.2 & & 0.039737 \\
\hline $1 \mathrm{H}-1,30$ & 0.30 & 68.2 & 75.3 & & 0.051894 \\
\hline $1 \mathrm{H}-1,35$ & 0.35 & 72.1 & 82.4 & & 0.058857 \\
\hline $1 \mathrm{H}-1,40$ & 0.40 & 76.9 & 80.5 & & 0.066982 \\
\hline $1 \mathrm{H}-1,45$ & 0.45 & 77.4 & 58.8 & & 0.089149 \\
\hline $1 \mathrm{H}-1,50$ & 0.50 & 76.8 & 59.1 & & 0.1255 \\
\hline $1 \mathrm{H}-1,55$ & 0.55 & 74.7 & 67.9 & & 0.11079 \\
\hline $1 \mathrm{H}-1,60$ & 0.60 & 66.8 & 80.6 & & 0.089831 \\
\hline $1 \mathrm{H}-1,65$ & 0.65 & 67.8 & 86.4 & & 0.083761 \\
\hline $1 \mathrm{H}-1,70$ & 0.70 & 69.3 & 71.9 & & 0.065555 \\
\hline $1 \mathrm{H}-1,75$ & 0.75 & 68.1 & 62.2 & & 0.062376 \\
\hline $1 \mathrm{H}-1,80$ & 0.80 & 65.9 & 59.8 & & 0.069185 \\
\hline $1 \mathrm{H}-1,85$ & 0.85 & 65.2 & 59.7 & & 0.056174 \\
\hline $1 \mathrm{H}-1,90$ & 0.90 & 67.3 & 62.4 & & 0.050081 \\
\hline $1 \mathrm{H}-1,95$ & 0.95 & 65.5 & 76 & & 0.048367 \\
\hline $1 \mathrm{H}-1,100$ & 1.00 & 67 & 109.4 & & 0.043859 \\
\hline $1 \mathrm{H}-1,105$ & 1.05 & 67.2 & 108.3 & & 0.041108 \\
\hline $1 \mathrm{H}-1,110$ & 1.10 & 63.3 & 98.5 & & 0.047328 \\
\hline $1 \mathrm{H}-1,115$ & 1.15 & 64.1 & 97.7 & & 0.054528 \\
\hline $1 \mathrm{H}-1,120$ & 1.20 & 66.7 & 95.5 & & 0.064302 \\
\hline $1 \mathrm{H}-1,125$ & 1.25 & 65.7 & 95.6 & & 0.06854 \\
\hline $1 \mathrm{H}-1,130$ & 1.30 & 64.2 & 92.4 & & 0.063498 \\
\hline $1 \mathrm{H}-1,135$ & 1.35 & 60.7 & 93 & & 0.056491 \\
\hline $1 \mathrm{H}-1,140$ & 1.40 & & & & \\
\hline $1 \mathrm{H}-1,145$ & 1.45 & & & & \\
\hline $1 \mathrm{H}-1,150$ & 1.50 & & & & \\
\hline $1 \mathrm{H}-2,0$ & 1.50 & & & & \\
\hline $1 \mathrm{H}-2,5$ & 1.55 & & & & \\
\hline $1 \mathrm{H}-2,10$ & 1.60 & & & & \\
\hline $1 \mathrm{H}-2,15$ & 1.65 & 62.6 & 90.4 & & 0.064971 \\
\hline $1 \mathrm{H}-2,20$ & 1.70 & 65.5 & 84.3 & & 0.070444 \\
\hline $1 \mathrm{H}-2,25$ & 1.75 & 73.6 & 78.6 & & 0.066624 \\
\hline $1 \mathrm{H}-2,30$ & 1.80 & & & & \\
\hline $1 \mathrm{H}-2,35$ & 1.85 & 73.7 & 96.9 & & 0.05686 \\
\hline $1 \mathrm{H}-2,40$ & 1.90 & 74.4 & 94.5 & & 0.054415 \\
\hline $1 \mathrm{H}-2,45$ & 1.95 & 72.8 & 98.2 & & 0.045478 \\
\hline $1 \mathrm{H}-2,50$ & 2.00 & 74.8 & 100.6 & & 0.035453 \\
\hline $1 \mathrm{H}-2,55$ & 2.05 & 72.7 & 99.3 & & 0.030256 \\
\hline $1 \mathrm{H}-2,60$ & 2.10 & 67.2 & 95.3 & & 0.030193 \\
\hline $1 \mathrm{H}-2,65$ & 2.15 & 68.4 & 96.8 & & 0.031033 \\
\hline $1 \mathrm{H}-2,70$ & 2.20 & 68.3 & 84.2 & & 0.03413 \\
\hline $1 \mathrm{H}-2,75$ & 2.25 & 61.2 & 74.5 & & 0.038089 \\
\hline $1 \mathrm{H}-2,80$ & 2.30 & 62.4 & 80.3 & & 0.040814 \\
\hline $1 \mathrm{H}-2,85$ & 2.35 & 70.9 & 80.3 & & 0.043866 \\
\hline $1 \mathrm{H}-2,90$ & 2.40 & 66.2 & 53.6 & & 0.059384 \\
\hline $1 \mathrm{H}-2,95$ & 2.45 & 65 & 75 & & 0.043951 \\
\hline $1 \mathrm{H}-2,100$ & 2.50 & 63.7 & 107 & & 0.031946 \\
\hline $1 \mathrm{H}-2,105$ & 2.55 & 65.7 & 101.3 & & 0.030403 \\
\hline $1 \mathrm{H}-2,110$ & 2.60 & 71.9 & 81.2 & & 0.042755 \\
\hline $1 \mathrm{H}-2,115$ & 2.65 & 74.3 & 104.4 & & 0.045477 \\
\hline $1 \mathrm{H}-2,120$ & 2.70 & 74 & 88.2 & & 0.03286 \\
\hline $1 \mathrm{H}-2,125$ & 2.75 & & & & \\
\hline $1 \mathrm{H}-2,130$ & 2.80 & 72.2 & 106.6 & & 0.034496 \\
\hline $1 \mathrm{H}-2,135$ & 2.85 & 71.8 & 93.1 & & 0.039783 \\
\hline $1 \mathrm{H}-2,140$ & 2.90 & & & & \\
\hline $1 \mathrm{H}-2,145$ & 2.95 & & & & \\
\hline
\end{tabular}

Blank cells indicate depth levels where data were either not available (i.e., FlexIT-corrected declination data for nonoriented cores) or removed because of disturbance, voids, or measurement edge effects. Only a portion of this table appears here. The complete table is available in ASCII. 
Table T16. Polarity boundaries, Site U1423.

\begin{tabular}{|c|c|c|c|c|c|c|c|c|c|c|c|}
\hline \multicolumn{2}{|c|}{ Core, section, interval $(\mathrm{cm})$} & \multirow[b]{2}{*}{ Polarity boundary } & \multirow{2}{*}{$\begin{array}{l}\text { Age } \\
(\mathrm{Ma})\end{array}$} & \multicolumn{4}{|c|}{ Depth CSF-A (m) } & \multicolumn{4}{|c|}{ Depth CCSF-D (m) } \\
\hline Top & Bottom & & & Top & Bottom & Midpoint & \pm & Top & Bottom & Midpoint & \pm \\
\hline $\begin{array}{c}346-U 1423 \mathrm{~A}- \\
6 \mathrm{H}-5, \sim 45\end{array}$ & $\begin{array}{c}346-\mathrm{U} 1423 \mathrm{~A}- \\
6 \mathrm{H}-6, \sim 55\end{array}$ & (B) C1n (Brunhes/Matuyama) & 0.781 & 51.70 & 53.30 & 52.50 & 0.80 & 54.09 & 55.69 & 54.89 & 0.80 \\
\hline $7 \mathrm{H}-2, \sim 10$ & $7 \mathrm{H}-3, \sim 40$ & (T) C1r.1n (Jaramillo) & 0.988 & 56.40 & 58.20 & 57.30 & 0.90 & 59.40 & 61.20 & 60.30 & 0.90 \\
\hline $7 \mathrm{H}-5, \sim 20$ & $7 \mathrm{H}-5, \sim 60$ & (B) C1r.1n (Jaramillo) & 1.072 & 61.00 & 61.40 & 61.20 & 0.20 & 64.00 & 64.40 & 64.20 & 0.20 \\
\hline $8 \mathrm{H}-7, \sim 45$ & $9 \mathrm{H}-2, \sim 105$ & (T) C2n (Olduvai) & 1.778 & 73.76 & 76.36 & 75.06 & 1.30 & 77.60 & 80.20 & 78.90 & 1.30 \\
\hline $11 \mathrm{H}-2, \sim 130$ & $11 \mathrm{H}-2, \sim 20$ & (B) C2n (Olduvai) & 1.945 & 93.40 & 95.60 & 94.50 & 1.10 & 97.89 & 100.09 & 98.99 & 1.10 \\
\hline $13 \mathrm{H}-1, \sim 80$ & $13 \mathrm{H}-1, \sim 20$ & (B) C2r (Matuyama/Gauss) & 2.581 & 111.40 & 112.60 & 112.00 & 0.60 & 116.30 & 117.50 & 116.90 & 0.60 \\
\hline $\begin{array}{l}\text { 346-U1423B- } \\
\text { 7H-1, 10 }\end{array}$ & $\begin{array}{l}\text { 346-U1423B- } \\
7 \mathrm{H}-1 \sim 50\end{array}$ & & & & & & & & & & \\
\hline $7 \mathrm{H}-1, \sim 10$ & $7 \mathrm{H}-1, \sim 50$ & (B) C1n (Brunhes/Matuyama) & 0.181 & $\begin{array}{l}51.30 \\
5790-1000\end{array}$ & 52.10 & $\begin{array}{l}51.70 \\
58.40\end{array}$ & 0.40 & 53.40 & 54.20 & 53.80 & 0.40 \\
\hline $7 \mathrm{H}-5, \sim 130$ & $7 \mathrm{H}-5, \sim 80$ & (T) C1r.1n (Jaramillo) & 0.988 & 57.90 & 58.90 & 58.40 & 0.50 & 60.00 & 61.00 & 60.50 & 0.50 \\
\hline $8 \mathrm{H}-1, \sim 150$ & $8 \mathrm{H}-1, \sim 120$ & (B) C1r.1n (Jaramillo) & 1.072 & 62.00 & 62.60 & 62.30 & 0.30 & 64.29 & 64.89 & 64.59 & 0.30 \\
\hline $9 \mathrm{H}-4, \sim 110$ & $9 \mathrm{H}-4, \sim 90$ & (T) C2n (Olduvai) & 1.778 & 75.80 & 76.20 & 76.00 & 0.20 & 78.61 & 79.01 & 78.81 & 0.20 \\
\hline- & - & (B) C2n (Olduvai) & - & - & - & - & - & - & - & - & - \\
\hline $13 \mathrm{H}-4, \sim 150$ & $13 \mathrm{H}-4, \sim 50$ & (B) C2r (Matuyama/Gauss) & 2.581 & 112.60 & 114.60 & 113.60 & 1.00 & 117.80 & 119.80 & 118.80 & 1.00 \\
\hline
\end{tabular}

Bold $=$ boundaries that are relatively well defined. $B=$ Bottom, $T=$ top. $-=$ not observed . 
Table T17. Results from APCT-3 temperature profiles, Site U1423.

\begin{tabular}{|c|c|c|c|c|c|}
\hline Core & $\begin{array}{l}\text { Minimum } \\
\text { temperature } \\
\text { at mudline } \\
\left({ }^{\circ} \mathrm{C}\right)\end{array}$ & $\begin{array}{c}\text { Average } \\
\text { temperature } \\
\text { at mudline } \\
\left({ }^{\circ} \mathrm{C}\right)\end{array}$ & $\begin{array}{c}\text { Depth } \\
\text { CSF-A (m) }\end{array}$ & $\begin{array}{c}\text { In situ } \\
\text { temperature } \\
\left({ }^{\circ} \mathrm{C}\right)\end{array}$ & $\begin{array}{l}\text { Thermal } \\
\text { resistance } \\
\left(\mathrm{m}^{2} \mathrm{~K} / \mathrm{W}\right)\end{array}$ \\
\hline \multicolumn{6}{|l|}{ 346-U1423A- } \\
\hline $4 \mathrm{H}$ & 0.21 & 0.48 & 35.8 & 5.50 & 37.91 \\
\hline $7 \mathrm{H}$ & 0.23 & 0.43 & 64.3 & 9.55 & 68.03 \\
\hline $10 \mathrm{H}$ & 0.22 & 0.47 & 92.8 & 13.54 & 98.10 \\
\hline $13 \mathrm{H}$ & 0.24 & 0.48 & 121.3 & 17.45 & 128.12 \\
\hline Average: & 0.23 & 0.47 & & & \\
\hline
\end{tabular}

In situ temperatures were determined using TP-Fit software by Martin Heesemann. Thermal resistance was calculated from thermal conductivity data (see "Physical properties") corrected for in situ conditions (see "Downhole measurements" in the "Methods" chapter [Tada et al., 2015b]). 
Table T18. Vertical offsets required to correlate specific features among cores from adjacent holes, Site U1423.

\begin{tabular}{|c|c|c|}
\hline Core & $\begin{array}{c}\text { Vertical } \\
\text { offset }(m)\end{array}$ & $\mathrm{Y} / \mathrm{N}$ \\
\hline \multicolumn{3}{|c|}{ 346-U1423A- } \\
\hline $1 \mathrm{H}$ & 0 & $\mathrm{~N}$ \\
\hline $2 \mathrm{H}$ & 0.474 & $\mathrm{Y}$ \\
\hline $3 \mathrm{H}$ & 0.862 & $\mathrm{Y}$ \\
\hline $4 \mathrm{H}$ & 1.537 & $\mathrm{Y}$ \\
\hline $5 \mathrm{H}$ & 2.135 & $\mathrm{Y}$ \\
\hline $6 \mathrm{H}$ & 2.387 & $\mathrm{Y}$ \\
\hline $7 \mathrm{H}$ & 3.001 & $\mathrm{Y}$ \\
\hline $8 \mathrm{H}$ & 3.599 & $\mathrm{Y}$ \\
\hline $9 \mathrm{H}$ & 3.835 & $\mathrm{Y}$ \\
\hline $10 \mathrm{H}$ & 4.185 & $\mathrm{Y}$ \\
\hline $11 \mathrm{H}$ & 4.488 & $\mathrm{Y}$ \\
\hline $12 \mathrm{H}$ & 4.006 & $\mathrm{Y}$ \\
\hline $13 \mathrm{H}$ & 4.903 & $\mathrm{Y}$ \\
\hline $14 \mathrm{H}$ & 4.977 & $\mathrm{Y}$ \\
\hline $15 \mathrm{H}$ & 5.439 & $\mathrm{Y}$ \\
\hline $16 \mathrm{H}$ & 6.317 & $\mathrm{Y}$ \\
\hline $17 \mathrm{H}$ & 6.341 & $\mathrm{Y}$ \\
\hline $18 \mathrm{H}$ & 6.830 & $\mathrm{Y}$ \\
\hline $19 \mathrm{H}$ & 7.480 & $\mathrm{Y}$ \\
\hline $20 \mathrm{H}$ & 7.615 & $\mathrm{Y}$ \\
\hline $21 \mathrm{H}$ & 7.914 & $\mathrm{Y}$ \\
\hline $22 \mathrm{H}$ & 8.091 & $\mathrm{Y}$ \\
\hline \multicolumn{3}{|c|}{ 346-U1423B- } \\
\hline $1 \mathrm{H}$ & 0.233 & $\mathrm{Y}$ \\
\hline $2 \mathrm{H}$ & 0.435 & $\mathrm{Y}$ \\
\hline $3 \mathrm{H}$ & 0.804 & $\mathrm{Y}$ \\
\hline $4 \mathrm{H}$ & 1.161 & $\mathrm{Y}$ \\
\hline $5 \mathrm{H}$ & 1.432 & $\mathrm{Y}$ \\
\hline $6 \mathrm{H}$ & 2.135 & $\mathrm{Y}$ \\
\hline $7 \mathrm{H}$ & 2.104 & $\mathrm{Y}$ \\
\hline $8 \mathrm{H}$ & 2.286 & $\mathrm{Y}$ \\
\hline $9 \mathrm{H}$ & 2.811 & $\mathrm{Y}$ \\
\hline $10 \mathrm{H}$ & 3.548 & $\mathrm{Y}$ \\
\hline $11 \mathrm{H}$ & 4.278 & $\mathrm{Y}$ \\
\hline $12 \mathrm{H}$ & 4.740 & $\mathrm{Y}$ \\
\hline $13 \mathrm{H}$ & 5.198 & $\mathrm{Y}$ \\
\hline $14 \mathrm{H}$ & 5.782 & $\mathrm{Y}$ \\
\hline $15 \mathrm{H}$ & 5.886 & $\mathrm{Y}$ \\
\hline $16 \mathrm{H}$ & 5.549 & $\mathrm{Y}$ \\
\hline $17 \mathrm{H}$ & 6.274 & $\mathrm{Y}$ \\
\hline $18 \mathrm{X}$ & 6.274 & $\mathrm{~N}$ \\
\hline $19 \mathrm{H}$ & 6.907 & $\mathrm{Y}$ \\
\hline $20 \mathrm{H}$ & 7.188 & $\mathrm{Y}$ \\
\hline $21 \mathrm{H}$ & 7.082 & $\mathrm{Y}$ \\
\hline $22 \mathrm{H}$ & 7.211 & $\mathrm{Y}$ \\
\hline $23 \mathrm{H}$ & 7.446 & $\mathrm{Y}$ \\
\hline $24 \mathrm{H}$ & 7.616 & $\mathrm{Y}$ \\
\hline $25 \mathrm{H}$ & 7.616 & $\mathrm{~N}$ \\
\hline $26 \mathrm{H}$ & 7.616 & $\mathrm{~N}$ \\
\hline $27 \mathrm{H}$ & 7.616 & $\mathrm{~N}$ \\
\hline $28 \mathrm{H}$ & 7.616 & $N$ \\
\hline \multicolumn{3}{|c|}{ 346-U1423C- } \\
\hline $2 \mathrm{H}$ & 6.417 & $\mathrm{Y}$ \\
\hline $3 \mathrm{H}$ & 6.708 & $\mathrm{Y}$ \\
\hline $4 \mathrm{H}$ & 6.095 & $\mathrm{Y}$ \\
\hline $5 x$ & 5.978 & $\mathrm{Y}$ \\
\hline $6 \mathrm{H}$ & 6.194 & $Y$ \\
\hline $7 X$ & 6.194 & $N$ \\
\hline $8 \mathrm{H}$ & 6.373 & $Y$ \\
\hline $9 \mathrm{H}$ & 7.908 & $Y$ \\
\hline
\end{tabular}


Table T19. Splice intervals, Site U1423.

\begin{tabular}{|c|c|c|c|c|c|c|c|c|}
\hline Hole, core, section & $\begin{array}{c}\text { Depth in } \\
\text { section }(\mathrm{cm})\end{array}$ & $\begin{array}{c}\text { Depth } \\
\text { CSF-A (m) }\end{array}$ & $\begin{array}{c}\text { Depth } \\
\text { CCSF-D (m) }\end{array}$ & Hole, core, section & $\begin{array}{c}\text { Depth in } \\
\text { section }(\mathrm{cm})\end{array}$ & $\begin{array}{c}\text { Depth } \\
\text { CSF-A (m) }\end{array}$ & $\begin{array}{c}\text { Depth } \\
\text { CCSF-D (m) }\end{array}$ & $\begin{array}{l}\text { Data used } \\
\text { to tie }\end{array}$ \\
\hline 346- & & & & $346-$ & & & & \\
\hline U1423A-1H-1 & 0.0 & 0.00 & 0.00 & U1423A-1H-5 & 74.5 & 6.74 & 6.74 & Blue \\
\hline U1423B-2H-2 & 71.0 & 6.31 & 6.74 & U1423B-2H-6 & 136.7 & 12.97 & 13.40 & Blue \\
\hline U1423A-2H-4 & 112.9 & 12.93 & 13.40 & U1423A-2H-6 & 126.4 & 16.06 & 16.54 & Blue \\
\hline U1423B-3H-2 & 63.4 & 15.73 & 16.54 & U1423B-3H-7 & 30.3 & 22.90 & 23.71 & Blue \\
\hline U1423A-3H-5 & 4.5 & 22.84 & 23.71 & U1423A-3H-7 & 1.2 & 25.81 & 26.67 & Blue \\
\hline U1423B-4H-2 & 91.3 & 25.51 & 26.67 & U1423B-4H-7 & 41.1 & 32.48 & 33.64 & Blue \\
\hline U1423A-4H-4 & 135.4 & 32.10 & 33.64 & U1423A-4H-6 & 142.5 & 35.17 & 36.71 & Blue \\
\hline U1423B-5H-2 & 118.0 & 35.28 & 36.71 & U1423B-5H-6 & 134.8 & 41.45 & 42.88 & Blue \\
\hline U1423A-5H-4 & 44.5 & 40.75 & 42.88 & U1423A-5H-7 & 11.4 & 44.72 & 46.86 & Blue \\
\hline U1423B-6H-2 & 112.4 & 44.72 & 46.86 & U1423B-6H-6 & 63.4 & 50.23 & 52.37 & Blue \\
\hline U1423A-6H-4 & 23.2 & 49.98 & 52.37 & U1423A-6H-7 & 8.0 & 54.14 & 56.53 & Blue \\
\hline U1423B-7H-2 & 132.3 & 54.42 & 56.53 & U1423B-7H-6 & 129.6 & 60.40 & 62.50 & Blue \\
\hline U1423A-7H-4 & 19.9 & 59.50 & 62.50 & U1423A-7H-6 & 87.9 & 63.18 & 66.18 & Blue \\
\hline U1423B-8H-2 & 129.3 & 63.89 & 66.18 & U1423B-8H-6 & 86.9 & 69.47 & 71.76 & Blue \\
\hline U1423A-8H-3 & 85.7 & 68.16 & 71.76 & U1423A-8H-6 & 89.5 & 72.69 & 76.29 & Blue \\
\hline U1423B-9H-2 & 138.3 & 73.48 & 76.29 & U1423B-9H-7 & 16.6 & 79.77 & 82.58 & Blue \\
\hline U1423A-9H-4 & 44.1 & 78.74 & 82.58 & U1423A-9H-6 & 137.0 & 82.67 & 86.51 & Blue \\
\hline U1423B-10H-2 & 139.7 & 82.96 & 86.51 & U1423B-10H-6 & 48.4 & 88.04 & 91.59 & Blue \\
\hline U1423A-10H-3 & 110.8 & 87.41 & 91.59 & U1423A-10H-7 & 12.4 & 92.42 & 96.61 & Blue \\
\hline U1423B-11H-2 & 123.1 & 92.33 & 96.61 & U1423B-11H-6 & 109.5 & 98.19 & 102.47 & Blue \\
\hline U1423A-11H-4 & 68.5 & 97.99 & 102.47 & U1423A-11H-6 & 144.6 & 101.75 & 106.23 & Blue \\
\hline U1423B-12H-2 & 89.4 & 101.49 & 106.23 & U1423B-12H-7 & 15.5 & 108.25 & 112.99 & Blue \\
\hline U1423A-12H-5 & 68.8 & 108.99 & 112.99 & U1423A-12H-7 & 17.2 & 111.47 & 115.48 & Blue \\
\hline U1423B-13H-2 & 18.0 & 110.28 & 115.48 & U1423B-13H-5 & 114.8 & 115.75 & 120.95 & Blue \\
\hline U1423A-13H-3 & 124.3 & 116.04 & 120.95 & U1423A-13H-6 & 62.3 & 119.92 & 124.83 & Blue \\
\hline U1423B-14H-1 & 94.5 & 119.04 & 124.83 & U1423B-14H-5 & 118.9 & 125.29 & 131.07 & Blue \\
\hline U1423A-14H-4 & 29.4 & 126.09 & 131.07 & U1423A-14H-7 & 64.5 & 130.94 & 135.92 & Blue \\
\hline U1423B-15H-2 & 93.5 & 130.04 & 135.92 & U1423B-15H-3 & 95.8 & 131.56 & 137.44 & Blue \\
\hline U1423A-15H-1 & 120.6 & 132.01 & 137.44 & U1423A-15H-6 & 36.2 & 138.67 & 144.11 & Blue \\
\hline U1423C-4H-4 & 51.6 & 138.02 & 144.11 & U1423C-4H-6 & 136.6 & 141.87 & 147.96 & Blue \\
\hline U1423A-16H-1 & 134.3 & 141.64 & 147.96 & U1423A-16H-2 & 94.4 & 142.74 & 149.06 & Blue \\
\hline U1423B-17H-1 & 68.7 & 142.79 & 149.06 & U1423B-17H-6 & 146.6 & 151.07 & 157.34 & Blue and GRA \\
\hline U1423C-6H-1 & 114.6 & 151.15 & 157.34 & U1423C-6H-7 & 20.0 & 159.25 & 165.44 & MS point \\
\hline U1423B-19H-1 & 43.8 & 158.54 & 165.44 & U1423B-19H-6 & 3.0 & 165.60 & 172.51 & GRA \\
\hline U1423A-18H-5 & 57.8 & 165.68 & 172.51 & U1423A-18H-7 & 30.5 & 168.41 & 175.23 & Blue \\
\hline U1423B-20H-1 & 44.7 & 168.05 & 175.23 & U1423B-20H-5 & 134.0 & 174.94 & 182.13 & Blue \\
\hline U1423A-19H-5 & 4.7 & 174.65 & 182.13 & U1423A-19H-7 & 3.2 & 177.63 & 185.11 & Blue \\
\hline U1423B-21H-1 & 93.1 & 178.03 & 185.11 & U1423B-21H-4 & 53.4 & 182.13 & 189.22 & Blue \\
\hline U1423A-20H-3 & 50.1 & 181.60 & 189.22 & U1423A-20H-6 & 27.1 & 185.87 & 193.49 & MS and GRA \\
\hline U1423B-22H-3 & 67.5 & 186.27 & 193.49 & U1423B-22H-7 & 18.0 & 191.78 & 198.99 & GRA \\
\hline U1423A-21H-3 & 47.7 & 191.08 & 198.99 & U1423A-21H-5 & 148.2 & 195.08 & 203.00 & GRA \\
\hline U1423B-23H-3 & 45.0 & 195.55 & 203.00 & U1423B-23H-6 & 127.1 & 200.87 & 208.32 & GRA \\
\hline U1423A-22H-3 & 12.6 & 200.23 & 208.32 & U1423A-22H-6 & 68.1 & 205.28 & 213.37 & GRA \\
\hline U1423B-24H-3 & 115.5 & 205.76 & 213.37 & U1423B-24H-7 & 0.6 & 211.25 & 218.80 & \\
\hline
\end{tabular}

GRA = gamma ray attenuation, MS = magnetic susceptibility, Blue = RGB blue datum, MS point = point magnetic susceptibility. 
Table T20. CCSF-C depth scale, Holes U1423A and U1423B.

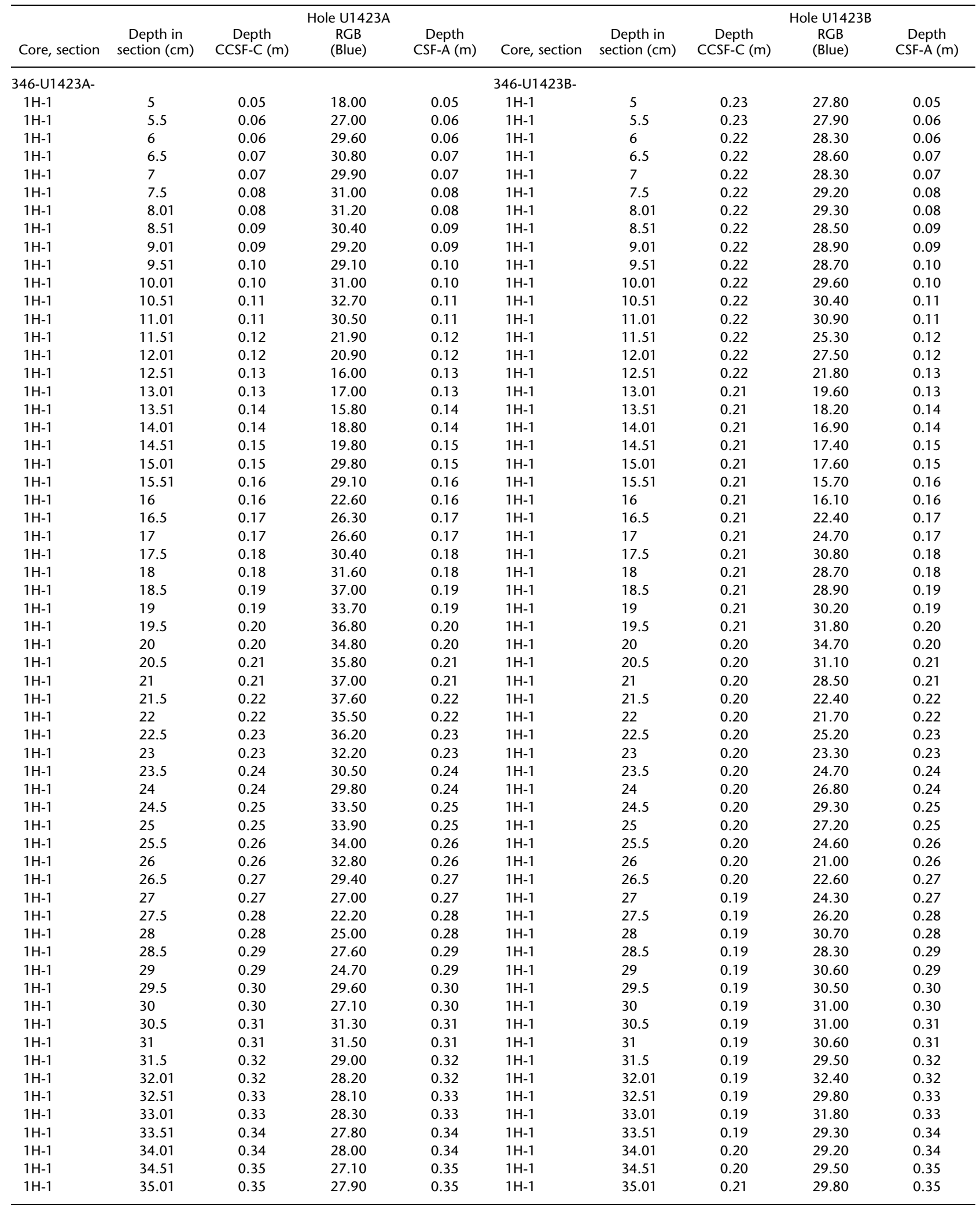

Only a portion of this table appears here. The complete table is available as ASCII. 